\title{
Did Timing Matter? Life Cycle Differences in Effects of Exposure to the Great Recession
}

\author{
by \\ Kevin Rinz \\ U.S. Census Bureau
}

CES 19-25

September, 2019

The research program of the Center for Economic Studies (CES) produces a wide range of economic analyses to improve the statistical programs of the U.S. Census Bureau. Many of these analyses take the form of CES research papers. The papers have not undergone the review accorded Census Bureau publications and no endorsement should be inferred. Any opinions and conclusions expressed herein are those of the author(s) and do not necessarily represent the views of the U.S. Census Bureau. All results have been reviewed to ensure that no confidential information is disclosed. Republication in whole or part must be cleared with the authors.

To obtain information about the series, see www.census.gov/ces or contact Christopher Goetz, Editor, Discussion Papers, U.S. Census Bureau, Center for Economic Studies 5K038E, 4600 Silver Hill Road, Washington, DC 20233, CES.Working.Papers@ census.gov. To subscribe to the series, please click here. 


\begin{abstract}
Exposure to a recession can have persistent, negative consequences, but does the severity of those consequences depend on when in the life cycle a person is exposed? I estimate the effects of exposure to the Great Recession on employment and earnings outcomes for groups defined by year of birth over the ten years following the beginning of the recession. With the exception of the oldest workers, all groups experience reductions in earnings and employment due to local unemployment rate shocks during the recession. Younger workers experience the largest earnings losses in percent terms (up to 13 percent), in part because recession exposure makes them persistently less likely to work for high-paying employers even as their overall employment recovers more quickly than older workers'. Younger workers also experience reductions in earnings and employment due to changes in local labor market structure associated with the recession. These effects are substantially smaller in magnitude but more persistent than the effects of unemployment rate increases.
\end{abstract}

Keyword: Great Recession, unemployment, earnings, labor market concentration

JEL Classification: J30, J60

\footnotetext{
* This paper is intended to inform interested parties of ongoing research and to encourage discussion. Any opinions and conclusions expressed herein are those of the author and do not necessarily reflect the views of the U.S. Census Bureau. All results have been reviewed to ensure that no confidential information is disclosed. The statistical summaries reported in this paper have been cleared by the Census Bureau's Disclosure Review Board, release authorization number CBDRB-FY19-376, CBDRB-FY19-431, CBDRB-FY19-500, CBDRB-FY2019-CES005-005, and CBDRB-FY2019-CES005-013. I thank Leah Clark, John Coglianese, Arin Dube, Harris Eppsteiner, Martha Gimbel, and Abigail Wozniak for helpful comments and conversations, and Danny Yagan for sharing the crosswalk used in his analysis. Contact: kevin.rinz@census.gov
} 


\section{Introduction}

The Great Recession caused enormous disruption in labor markets. Nationally, the hiring rate fell by more than 30 percent, the number of job openings fell by more than half, and the unemployment rate more than doubled, peaking at ten percent. Some groups saw their unemployment rates rise even higher; for workers under 25 years old, it reached 19.5 percent, and it remains more than twice as high as the overall unemployment rate 1 Locally, more than 90 percent of commuting zones lost establishments on net; the median commuting zone had 3.8 percent fewer establishments in 2009 than in 2007, with the hardest hit areas losing 5.4 to 15.7 percent of their establishments ${ }^{2}$ Over the same period, all but five commuting zones saw their unemployment rates increase. The median increase was 3.6 percentage points, and the hardest hit areas saw increases of 5.2 to 11.8 percentage points $3^{3}$ Nearly 7.8 million people were laid off in the first quarter of 2009 alone, about 40 percent more than in the average quarter in 2006 4

Job loss can have persistent and even permanent negative consequences (Topel, 1990, Ruhm, 1991; Jacobson et al., 1993; Neal, 1995; Sullivan and Von Wachter, 2009; Davis and Von Wachter, 2011; Hershbein, 2012, Jarosch, 2015; Yagan, 2018, Stuart, 2019). Analysis of the consequences of job loss often focuses on prime-age workers with relatively strong labor force attachment and occasionally restricts attention to men, but given changes in the prevalence of work, education, and other activities over the life cycle, the nature of the harm from recession exposure may depend on when in a person's life they are exposed to it. Younger workers might consider pursuing additional education but see the opportunity cost and/or liquidity constraints associated with doing so change. Older workers might be forced to adjust retirement plans or return to the labor force to make ends meet. People not losing jobs themselves can also suffer from environments in which job loss is prevalent if conditions make it harder for them to ask for a raise or change jobs to get one Beaudry and DiNardo, 1991; Topel and Ward, 1992). Some prior work has considered the consequences of graduating from college or otherwise entering the labor market during a recession $\mathrm{Kahn}, 2010$,

\footnotetext{
${ }^{1}$ Calculations from Job Openings and Labor Turnover Survey (JOLTS) for hiring rate and job openings data, Current Population Survey (CPS) for unemployment rate data.

${ }^{2}$ Calculations from County Business Patterns data. "Hardest hit" areas are those in the most-negative quartile of the percent change in number of establishments.

${ }^{3}$ Calculations from Local Area Unemployment Statistics data. "Hardest hit" areas are those in the top quartile of the change in the local unemployment rate.

${ }^{4}$ Calculation from JOLTS data.
} 
Oreopoulos et al., 2012; Schwandt and Von Wachter, 2019, Rothstein, 2019), but I do not know of any previous work that considers effects of recession exposure on workers of substantially different ages within the same framework and looks for heterogeneity in the effects of exposure across cohorts.

In this paper, I estimate the effects of exposure to the Great Recession on employment and earnings outcomes for groups of workers who were at different stages of their working lives when the recession started in 2007. The groups I consider correspond to popularly used generational definitions: Millennials were still in school or entering the workforce at the onset of the recession; members of Generation X (Gen-X) had largely entered the workforce but were still relatively early in their careers; Baby Boomers were later in their working lives but had generally not yet reached retirement; and the Silent Generation had largely reached retirement age when the recession began. Figure 1, which presents employment and earnings trajectories for these groups over the period considered here, illustrates these life-cycle differences well.

I implement a modified version of the approach used in Yagan (2018), estimating the effect of changes in the local unemployment rate between 2007 and 2009 on employment and earnings in each year through 2017. I estimate these effects on an individual-level panel of 4.1 million individuals constructed using data from Form W-2 and a variety of other administrative and survey sources. On average, exposure to an additional percentage point of increased local unemployment during the recession reduced the average worker's probability of being employed by abut 0.7 percentage points in 2010, with that magnitude declining steadily in subsequent years and becoming statistically insignificant in 2016. With regard to earnings, this same exposure cost workers up to about $\$ 600$ $\$ 700$ annually between 2009 and 2015 and over $\$ 400$ in 2016 and 2017.

The trajectory of the overall employment effect is driven by younger workers. The effect of recession exposure on Millennials' employment was most negative in 2010 and began steadily diminishing shortly thereafter. Their earnings, however, have shown little sign of recovery $5^{5}$ For Millennials, exposure to the average local unemployment shock during the recession reduced earnings in 2017 by nearly $\$ 3,000$ on average; from 2007 through 2017 , such exposure reduced earnings by more than $\$ 25,000$ in total, or about 13 percent of actual earnings over that period. A similar dynamic emerges for the next youngest workers in Generation X, though the recovery in their employment effects is

\footnotetext{
${ }^{5}$ I often use "recovery" in this paper to refer to the reduction in the magnitude of negative effects on employment and earnings. The underlying outcomes have of course changed over time, increasing for some groups and decreasing for others, but these changes are connected to the life cycle.
} 
less stark because they were less than half as severe as the effects for Millennials in absolute terms.

What drives the divergence between employment and earnings recoveries for younger workers? For Millennials in particular, two related factors appear to be at play. First, increased exposure to local unemployment shocks appears to have reduced their likelihood of completing any postsecondary degree by 1.3 percentage points per unit of exposure. Second, these shocks have also persistently reduced the likelihood of working for a high-paying employer ${ }^{6}$ This is in line with results from the literature on the "scarring" effects of conditions at labor market entry that suggest that negative long-term effects of these conditions are due to workers' first jobs being worse (Kahn, 2010, Oreopoulos et al., 2012, Schmeider et al., 2018) 7

In addition to heterogeneity in these effects by age at exposure, there are important differences in how the recession affected workers across demographic groups. Men were more adversely affected than women in terms of both employment and earnings, with the earnings differences being especially pronounced among middle-aged workers. Male Baby Boomers lost up to $\$ 2,500$ per percentage point of unemployment shock exposure in the worst years after the recession; for Baby Boomer women, this figure is only about $\$ 600$. Absolute differences across race groups are difficult to discern statistically, but relative to groups' own means, point estimates suggest black workers suffered earnings losses that were at least 40 percent larger than other groups.

Unemployment rates were not the only local economic condition that changed during the Great Recession. In particular, local labor market concentration increased during the Great Recession (Rinz, 2018). A growing literature documents a negative relationship between concentration and earnings, so I further modify my baseline empirical approach to estimate the effects of recessionrelated concentration shocks on earnings and employment. I find that increased concentration also reduces employment and earnings for younger workers. These effects are substantially smaller in magnitude than the effects of unemployment shocks, and they are realized more gradually, but they show little sign of recovery and if anything have grown larger over time, making them notably more persistent.

\footnotetext{
${ }^{6}$ This is true using a variety of measures. To provide one example, exposure to the average shock reduced Millennials' probability of working for an employer in the highest-paying quartile by 2.8 percentage points in 2017 . About 38 percent of Millennials worked for such employers that year.

Kahn (2010) finds that worse conditions at labor market entry increase educational attainment, though that analysis focuses on college graduates, and the much more severe 2007-2009 recession could plausibly have affected this margin differently than earlier recessions.
} 
The rest of this paper proceeds as follows: Section 2 describes the data used in this analysis; Section 3 lays out the empirical strategy; Section 4 discusses the results; and Section 5 concludes.

\section{Data}

I draw a two percent sample, stratified by year of birth, from the 2018 vintage of the Census Numident file, which contains one record for each individual who has received a Social Security number (SSN) and provides information on gender, citizenship, date of birth, and date of death, where applicable, among other things 8 I focus on individuals born between 1928 and 1996. For each person in this sample, I obtain information about earnings in each year from 2005 through 2017 from Form W-2. My primary earnings concept combines wage and salary earnings with deferred compensation 9 Dollar values are adjusted for inflation using the Consumer Price Index. I also obtain any available location information from Form 1040 (if they filed or were listed as a dependent), any 1099 information returns that were issued, the American Community Survey (ACS), and a variety of other administrative sources that have been collected in the Census Bureau's Master Address File - Auxiliary Reference File (MAF-ARF). I also obtain the type(s) of 1099 forms each individual received, as well as information on race and ethnicity from the ACS.

From these files, I construct a panel of earnings and geographic information at the individual level. I use location information to identify county, and by extension commuting zone, of residence 10 If geographic information is missing for up to three years between observations of an individual in the same commuting zone, I impute that observed commuting zone to those years with missing data. Where no earnings information is available for an individual in a given year, I set earnings to zero if location information is available or can be imputed. In my primary analysis sample, I include only individuals who had location information available for each year from 2005 through 2017 and who had not died as of the end of 2017. This gives me a sample of just over 4.1 million individuals, each

\footnotetext{
${ }^{8}$ Individuals are identified on this file (and on all others used here) via a Protected Identification Key (PIK), an anonymized identifier that is assigned by the Census Bureau's Person Identification Validation System (PVS) and serves as the linkage variable across datasets. See Wagner and Layne (2014) for more details.

${ }^{9}$ These are the only two types of income provided in the W-2 data available to me. Deferred compensation should be thought of as retirement contributions. I do not observe employee or employer contributions to employer sponsored health insurance premiums.

${ }^{10}$ More information on how I identify county of residence can be found in Appendix A. I use 1990 commuting zone definitions.
} 
observed 13 times 11 Table 1 reports summary information for individuals in my primary analysis sample. Individuals are assigned to generations using year of birth and the definitions currently used by the Pew Research Center (Dimock, 2019) 12

It is fairly unlikely that younger Millennials or older members of the Silent Generation were in the labor force for substantial portions of the period considered here ${ }^{13}$ I do not restrict my analysis to ages likely to have been working within these generations ${ }^{14}$ The youngest Millennials turned 16 in 2012, and I want to capture the effects of recession exposure on their early employment and earnings, while constructing my sample consistently for all groups. Young individuals who are not working appear in my data as having no earnings and not being employed, just like their older counterparts.

\section{Estimation}

I estimate the effects of exposure to the Great Recession using a strategy that is similar to Yagan (2018). Specifically, I estimate the fixed effects regression

$$
y_{i t}=\sum_{t=2005}^{2017} \beta_{t} \text { Shock }_{C Z 07(i)} \cdot 1[\text { Year }=t]+\sum_{a \in a g e s} \alpha_{a} \cdot 1\left[\text { Age }_{i t}=a\right]+\gamma_{i}+\delta_{t}+\varepsilon_{i t}
$$

where $y_{i t}$ is an earnings or employment outcome, $\alpha_{a}$ are age fixed effects, $\gamma_{i}$ are individual fixed effects, $\delta_{t}$ are year fixed effects, and $S h o c k_{C Z 07(i)}=U R_{C Z 07(i), 2009}-U R_{C Z 07(i), 2007}$ is the change in the unemployment rate between 2007 and 2009 in individual $i$ 's commuting zone of residence in $2007(C Z 07(i)){ }^{15}$ Standard errors are clustered on 2007 commuting zone of residence. I estimate separate regressions of this form for each group I analyze.

The omitted year interaction with the shock variable is 2006 ${ }^{16}$ Under the assumption that

\footnotetext{
${ }^{11}$ Constructing the analysis sample using more or less stringent data availability requirements has little qualitative effect on my estimates. Key estimates based on alternative samples are presented in Appendix A

${ }^{12}$ Using Pew's definitions, the years of birth for Millennials are 1981 through 1996, Generation X was 1965 through 1980, Baby Boomers were born from 1946 through 1964, and the Silent Generation was 1928 through 1945.

${ }^{13}$ In the case of the youngest Millennials, they may not have been legally permitted to work until near the end of the period covered by my data.

${ }^{14}$ The requirement that individuals survive through 2017 may implicitly exclude some older non-workers.

${ }^{15}$ Due to differences in data availability, I do not use the same specification as Yagan (2018), but our two approaches are conceptually similar. See Appendix A for more details.

${ }^{16}$ With 2006 serving as the reference year and the data beginning in 2005, I have essentially no capacity to investigate pre-recession trends in outcomes of interest. Fortunately, pre-recession effects presented in Figure 4 in Yagan (2018) are not suggestive of trends that would generate spurious negative estimates of the effects of recession exposure.
} 
local unemployment shocks are as good as randomly assigned, conditional on age, person, and year fixed effects, the coefficient $\beta_{t}$ gives the average change in earnings or employment, relative to 2006, in year $t$ due to a one percentage point increase in the local unemployment rate between 2007 and 2009 ${ }^{17}$ Information on local unemployment rates comes from the Bureau of Labor Statistics' Local Area Unemployment Statistics program. The unemployment rate in the average worker's commuting zone increased by about 4.6 percentage points between 2007 and 2009. The standard deviation of this unemployment shock is about two percentage points.

My primary outcomes of interest are earnings and employment. An individual is employed in year $t$ if her earnings are greater than zero. I primarily consider earnings effects in levels. Table B1 presents the main estimates discussed below as a percent of the contemporaneous outcome mean for the relevant group for select post-recession years; figures depicting the full set of estimates relative to mean outcomes, as well as estimates using log and inverse hyperbolic sine transformations, are reported in Appendix B.

\section{Results}

I begin by reporting estimates based on the 1957-1976 birth cohorts, as in Yagan (2018), then extend the analysis to consider additional cohorts and examine heterogeneity by groups of cohorts, gender, race and ethnicity, and other factors.

\subsection{Estimates Using Yagan (2018) Cohorts}

Figure 2 presents estimates of the effects of increased local unemployment during the Great Recession on employment and earnings through 2017 for individuals born between 1957 and 1976, the same cohorts used in Yagan (2018). Encouragingly, for the years covered by both analyses, the pattern of estimates is very similar. I replicate his headline result that a Great Recession unemployment shock that was one percentage point larger decreased the employment rate in 2015 by more than 0.3 percentage point. I also find that during much of the post-recession period, that same one

Given that my results are very similar to Yagan's in years covered by both analyses, his figure provides support for strategy employed here, as well.

${ }^{17}$ Unless otherwise indicated, all effects of unemployment shocks on employment and earnings outcomes will be discussed below on an annual basis, per percentage point of unemployment exposure. 
percentage point larger unemployment shock led earnings to be about $\$ 1,000$ lower per year on average.

Workers continue to experience adverse employment and earnings effects of unemployment shocks in the two additional years that are included in my analysis, but these effects are less severe than in earlier years. The estimates for the 2017 effects on employment and earnings are about 30 percent and 20 percent smaller, respectively, than their 2015 counterparts ${ }^{18}$ Even as these estimates suggest continued recovery from the worst effects of the recession since 2015, that recovery has been somewhat uneven. For both employment and earnings, 2016 estimates represented statistically significant improvement over 2015, but 2017 was little changed from 2016. This pattern differs somewhat from improvement in the overall prime-age employment rate, which increased by 0.7 percentage point from the end of 2015 to the end of 2016 and then by another 1.0 percentage point between the end of 2016 and the end of 2017.

\subsection{Estimates Using Additional Cohorts and by Generation}

Because the effects of exposure to unemployment shocks may depend on when in the life cycle one is exposed, I broaden my sample to include individuals born between 1928 and 1996. First, I re-estimate full sample effects, as in Section 4.1. Figure 3 reports these estimates. Estimates of the employment effect follow a strikingly different pattern when estimated using a broader set of cohorts than they do when estimated using only prime-age workers. Rather than becoming negative during the recession and remaining consistently so for several years after, the employment effect here starts to shrink steadily immediately after reaching its greatest magnitude in 2010 . A one percentage point larger unemployment shock during the recession reduced an exposed individual's probability of being employed in 2010 by 0.7 percentage point. By 2017, after statistically significant improvement in each year, that effect had declined to almost zero, suggesting full recovery of employment over this period on average for the full sample. Employment for more intensely exposed prime-age workers

\footnotetext{
${ }^{18}$ Improvement since 2015 is interesting because there was an influential view at the time that the economy was at or near full employment, and individuals who had not yet returned to work were relatively unlikely to do so in the future (Krueger, 2015). In its economic projections from March of that year, the central tendency of the Federal Open Market Committee's predicted longer run unemployment rate was 5.0 to 5.2 percent. Fifteen of the seventeen members polled believed it would be appropriate to start tightening monetary policy within the year (Federal Open Market Committee, 2015). The fact that the effects estimated here have diminished since then joins continued improvement in indicators like the unemployment rate as evidence that the labor market recovery had not run its course in 2015 .
} 
recovered more gradually over this period and had not returned to 2006 levels by 2017, as shown in Figure 2 .

Earnings effects in this broader sample are generally smaller in magnitude than they are for prime-age workers, but they follow a similar pattern over time. At its greatest severity, and additional percentage point of unemployment exposure cost the average worker a little over $\$ 700$ in 2013 , compared to more than $\$ 1,100$ for the average prime-age worker that same year. The magnitude of this effect had declined by about 35 percent by 2017 in both the full and prime-age samples, with most of this decline coming between 2014 and 2016.

Figure 4 shows estimates of the effects of local unemployment shocks on employment by generation. These estimates reveal important differences between younger and older workers' employment trajectories following the recession. Millennials saw substantially larger reductions in their probability of being employed immediately after the recession than did workers in other generations; the 1.2 percentage point reduction in their employment rate per one percentage point of unemployment shock exposure is more than twice the magnitude of this effect for any other generation. On top of this, Millennials were less likely to be working at the time than their prime-age counterparts; per Table 1, only 44.5 percent of Millennials were employed in 2005, compared with 84.6 percent of Generation X and 78.6 percent of Baby Boomers. Following that initial decline, though, Millennial employment recovered consistently and relatively quickly, following a trajectory similar to that seen in the full sample. By 2015, exposure to unemployment shocks had essentially no effect on Millennials' probability of being employed, and by 2017, Millennials exposed to larger shocks were actually slightly more likely to be employed than those exposed to smaller shocks.

Gen-X also saw steady but slower employment recovery after the recession. In 2017, members of Gen-X exposed to larger shocks were still less likely to be employed, but this effect was relatively small in magnitude (coefficient roughly 0.1 percentage point) and only marginally statistically significant. Baby Boomers remained nearly 0.3 percentage point less likely to be employed per unit of unemployment shock exposure in $2017{ }^{19}$ The oldest workers in my sample, members of the Silent Generation, had the smallest employment effect in percentage point terms (the coefficient's largest magnitude was nearly 0.3 percentage point in 2010) and saw it lose statistical significance in 2012

\footnotetext{
${ }^{19}$ For the sake of comparison, the cohorts used in Yagan (2018) correspond to older Gen-X/younger Baby Boomers here, so the fact that estimates in Figure 2 are basically between those in the panels corresponding to those generations in Figure 4 makes sense.
} 
and remain insignificant in the following years.

Figure 5 shows estimated earnings effects by generation. The oldest workers are the most striking group in this figure. Though their earnings effects are not statistically significant in any year, point estimates indicate that members of the Silent Generation who were exposed to larger local unemployment shocks earn more than those exposed to smaller shocks on average ${ }^{20}$ Though only speculative given the precision of these estimates, this could potentially be consistent with shocks late in the life cycle disrupting retirement plans and leading some workers who might otherwise have left the labor force to increase their labor supply. This highlights the limitations of using earnings as a measure of well-being. In this case, older workers' increased earnings may be a sign of their efforts to hold well-being constant in the face of worsening underlying circumstances.

Among other generations, the earnings trajectories look broadly similar to the full sample estimates. In dollar terms, Millennials' earnings effects are smaller in magnitude than Gen-X throughout the post recession period and smaller than the Baby Boomers' effects for much of it; in combination with positive point estimates for older workers, this explains why the full sample estimates are smaller than the prime-age estimates. However, Millennials were in the lower-earning early years of their working lives during and after the recession, and their earnings were most adversely affected by recession exposure relative to their mean 21 Exposure to the average local unemployment shock cost Millennials about 17 percent of their earnings on average in each of 2010 and 2011. Cumulatively, from 2007 through 2017, exposure to the average shock cost Millennials an amount equivalent to about 13 percent of total earnings over that period for the average Millennial worker. For Gen-X, that figure is about 9.1 percent, while Baby Boomers lost about 7.1 percent. If the Silent Generation's non-significant point estimates are taken at face value, they suggest that exposure to the average shock increased earnings by 7.2 percent during and after the recession.

For Millennials, this estimate of cumulative lost earnings is larger than previous estimates of the effects of recessions on young workers. Using Canadian data from 1982 through 1999, Oreopoulos

${ }^{20}$ Estimating earnings effects for the Silent Generation using logged earnings produces negative and significant estimates (see Figure B22). The differences between the log and level estimates suggests an important role for extensive margin adjustments in this group.

${ }^{21}$ Estimates of earnings effects as shares of mean earnings are reported in Appendix B. For these specific estimates, see Figure B1]. Log earnings estimates are consistent with the levels estimates as shares of mean earnings for this group. In particular, log earnings estimates for Millennials, which implicitly exclude individuals too young to work, are more negative than for other generations. This suggests that proportionally larger earnings losses for this group are not just a byproduct of lower mean earnings due to a larger share of individuals not working. 
et al. (2012) estimate that graduating from college into a recession cost workers five percent of cumulative income over ten years. Schwandt and Von Wachter (2019) find that entering the labor market during a moderate recession (unemployment increases three percentage points) would cost workers 60 percent of a year of earnings over the first decade of work, an amount comparable in magnitude to the Oreopoulos et al. (2012) estimate. If the Schwandt and Von Wachter (2019) estimate scales linearly with recession severity, it implies earnings losses comparable to what I find for Millennials, suggesting that my estimates may be large in part because of the greater severity of the 2007-2009 recession. For young workers, the earnings losses I find are even comparable to some estimates of losing one's job in a mass layoff, even though my analysis does not condition on job loss: Schmeider et al. (2018) find annual earnings losses due to layoffs of 15 percent lasting 15 years in German data. My estimates are smaller than other mass layoff-based estimates like Von Wachter et al. (2009), who find immediate earnings losses of 30 percent and long-run losses on 20 percent for workers who lost jobs during the 1980-1982 recession.

\subsection{Why Have Employment and Earnings Effects Diverged?}

For younger workers, Figures 4 and 5 highlight an interesting divergence between employment and earnings trajectories following the recession. Among Millennials and Gen-X, employment effects have nearly/completely gone away, but earnings effects remain near their most negative levels. By contrast, by 2017, Baby Boomers saw their employment effects recover by 50 percent relative to 2010 while their earnings effects recovered by 65 percent.

Why have older workers seen their earnings improve more quickly than employment after the recession while younger workers' earnings remain depressed even though the adverse employment effects of recession exposure have worn off entirely for them? Differential changes across generations in the likelihood of working for high-paying firms may help explain this divergence. Figure 6] shows, for each generation, the effects of unemployment shocks on the probability of working for an employer that is in the highest paying quartile, as measured using firm fixed effects estimated via a procedure inspired by Abowd et al. (1999) 22 Millennials, Gen-X, and Baby Boomers all see a sustained decline in the probability of working for a high-paying employer during the recession. After 2010, this probability began to recover for Gen-X and Baby Boomers, roughly in proportion to the rate

\footnotetext{
${ }^{22}$ This procedure is described in more detail in Appendix C
} 
at which their overall employment probabilities recovered. Millennials, though, experienced no such recovery. The effects of unemployment shocks on employment at high-paying employers continued to worsen for Millennials until 2014, after which year they improved modestly. This is despite the fact that Millennials overall employment effects began to recover after 2010 and diminished much more quickly than other generations 23 Together, these estimates suggest that the divergence between the employment and earnings recoveries experienced by Millennials may be due in part to the fact that recession exposure has made them persistently less likely to work for higher-paying employers, even as they are no longer less likely to be working. This is consistent with previous work on the "scarring" effects of the conditions workers face at labor market entry, parts of which suggest that workers' earnings suffer in the longer run because their initial jobs are worse on various dimensions Kahn, 2010; Oreopoulos et al., 2012; Schmeider et al., 2018).

Another related possibility is that exposure to local unemployment shocks altered employment and earnings trajectories by affecting educational attainment among younger workers. In theory, the sign of the effect of recession exposure on educational attainment is ambiguous. Worsening economic conditions decrease the opportunity cost of higher education and so might increase educational attainment. Alternatively, they could also reduce educational attainment by creating or exacerbating liquidity constraints, leading students to withdraw from or decline to enroll in college.

For respondents to the ACS, I observe educational attainment as of survey response. For Millennials who responded to the ACS at or after age 25, I can use this information to estimate the effect of recession exposure on educational attainment. Specifically, I can estimate

$$
y_{i}=\beta S h o c k_{C Z 07(i)}+X_{i} \gamma+\varepsilon_{i}
$$

where $y_{i}$ is an indicator for having completed a given level of educational attainment, $S h o c k_{C Z 07(i)}$ is the same local unemployment shock defined above, and $X_{i}$ is a set of individual characteristics, including interactions between year of survey response, age, race/ethnicity, and gender.

Figure 7 reports the effects of an additional percentage point increase in local unemployment on the probability of completing various amounts of education. Across formulations, these estimates suggest that being exposed to a more severe unemployment shock reduced Millennials' educational

\footnotetext{
${ }^{23}$ Other formulations of this analysis tell a similar story. Additional estimates are presented in Appendix C
} 
attainment. Each percentage point of exposure to local unemployment shocks reduced the likelihood of completing any post-secondary degree by 1.3 percentage points ${ }^{24}$ This is consistent with Stuart (2019), which found that younger children exposed more intensely to the 1980-1982 recession were less likely to complete four-year college degrees. These effects on educational attainment could contribute to the divergence between employment and earnings recovery discussed above. Millennials exposed to more severe shocks may have been forced to pursue work over education, reducing the magnitude of the adverse employment effect over time. This shift away from education could also reduce future earnings growth for these workers, possibly contributing to the persistence of both the reduced likelihood of working for high-paying employers and the negative earnings effects of local unemployment shocks.

\subsection{Estimates by Displacement Status}

The harm from losing a job during a recession is well documented, but workers who remain employed may also suffer if prevailing conditions make it more difficult to change jobs or ask for a raise (Beaudry and DiNardo, 1991). Annual data are not ideal for identifying employment transitions, but a few broad categories of workers can be identified and compared. Using data from W-2s, I can identify individuals who did not work at all in 2006, prior to the recession (about 1.4 million of the individuals in my sample); those who were working prior to the recession but then spent at least one full calendar year not working between 2007 and 2009 (about 400,000 individuals); those who worked at some point in every year during the recession, but saw their main employer (i.e. the one that paid the largest share of their earnings) change during that period (about 1.1 million individuals); and those who worked in all years of the recession and had the same main employer in all years (about 1.3 million individuals).

Because these groups are defined by my measure of employment, I focus on differences in earnings effects here. Figure 8 shows earnings effects for these four groups of workers based on all birth cohorts. In each group, including the two that were employed prior to the recession and did not experience a full year of nonemployment during it, I find significant reductions in earnings following

\footnotetext{
${ }^{24}$ Educational attainment is only measurable for ACS respondents as of the response date. Though all individuals in this analysis responded to the ACS at age 25 or older, some could have completed additional education after responding. This estimate is best considered an upper bound on the effect of exposure on final educational attainment, since part of the effect measured here could be delay in educational attainment rather than reduction.
} 
the recession. At this effect's largest magnitude, workers who remain employed but see their main employer change lose out on about $\$ 1,000$ per year per percentage point of local unemployment increase during the recession. This is similar to the dollar amount lost by workers who kept the same main employer throughout the recession. In both cases, this effect amounted to about two percent of annual earnings (or about ten percent for a shock of average magnitude) at its largest magnitude 25 Though the data used here cannot detect partial-year nonemployment spells, the fact that even workers who remain attached to their pre-recession primary employer through the duration of the recession see their earnings reduced by exposure to local unemployment shocks suggests that recession exposure is likely also harmful to non-displaced workers.

\subsection{Demographic Heterogeneity}

By a variety of measures, men fared worse than women during and after the Great Recession; for example, the unemployment rate for men peaked at 11.1 percent, while the unemployment rate for women never exceeded 9.0 percent. Were men and women differentially effected by exposure to local unemployment shocks?

Figure 9 shows estimated effects of unemployment shocks on employment and earnings by gender. In both cases, estimates indicate that these shocks hurt men more. An additional percentage point of exposure made women about 0.5 percentage point less likely to be employed in each year from 2009 through 2011, while for men this effect reached 0.8 percentage point in 2010. Over the period considered, about 68 to 71 percent of men work in a given year, while the same is true of 64 to 66 percent of women, so estimated effects for men are also larger relative to the mean employment rate. The absolute difference between employment effects on men and women is not permanent; by 2015, these estimates converge on each other, and neither gender's estimates are statistically significant in 2016 or 2017, nor are they statistically different from each other.

On earnings, men also fare worse than women in absolute terms. On average, men lose between $\$ 900$ and $\$ 1,500$ per year per percentage point of unemployment shock exposure in each year from 2009 through 2014. The corresponding estimate for women is only about $\$ 400$ to $\$ 500$. Women's estimates, however, show little sign of recovery following the recession, remaining around $\$ 430$ in

\footnotetext{
${ }^{25}$ Estimates for each generation are reported in Appendix D With the exception of the Silent Generation (for which my main point estimates suggest that recession exposure increased earnings), each generation's estimates are qualitatively similar to these full-sample estimates.
} 
2017 , while the $\$ 630$ effect on men that year is less than half the largest magnitude among their annual estimates. Differences between men's and women's estimates are statistically significant in all years. In relative terms, annual effects on men remain larger, reaching 3.3 percent of annual earnings in 2013; earnings effects for women reach up to 2.2 percent of annual earnings in 2011 ${ }^{26}$ Cumulatively, exposure to an unemployment shock of average magnitude cost men an amount equivalent to 9.6 percent of the average worker's total earnings between 2007 and 2017, while women lost 7.7 percent.

Looking across generations, the difference between overall effects on men and women appear to be driven by Generation X and the Baby Boomers. As shown in Figure 10, effects on employment for Millennial men and women follow very similar trajectories, and for the Silent Generation, neither gender's employment effects are generally statistically significant. Within Gen-X, men's employment was more adversely affected during the recession, though since 2011 effects on men's employment are not distinguishable from effects on women's employment, and point estimates suggest men's employment has recovered more quickly and more fully than women's. Among Baby Boomers, unemployment shocks also had larger employment effects on men than on women, though that difference largely emerged after the official end of the recession, and it remained statistically significant until 2017. Figure 11] shows a similar pattern for earnings: there is little absolute gender gap in earnings effects among Millennials, effects on the Silent Generation are not statistically significant, and an additional unit of unemployment exposure generally cost Gen-X and Baby Boomer men up to $\$ 1,800$ and $\$ 2,500$, respectively, in their worst years post-recession, compared to $\$ 1,000$ and $\$ 600$ for Gen-X and Baby Boomer women, respectively.27

As with gender, headline economic indicators show that the experience of the Great Recession differed substantially across groups defined by race and ethnicity 28 But did earnings and employment outcomes respond differentially to local shocks?

Figures 12 and 13 suggest that employment and earnings effects for White, Black, Asian, and Hispanic workers followed similar trajectories over the course of the recession and recovery ${ }^{29}$ Dur-

\footnotetext{
${ }^{26}$ Log earnings estimates tell a similar story.

${ }^{27}$ Earnings effects for Millennial men and women are statistically distinguishable from each other in many years, but the magnitudes of the differences are small.

${ }^{28}$ The White unemployment rate peaked at 9.2 percent in late 2009 , a few months before the Black unemployment rate reached 16.8 percent and a few months after the Hispanic unemployment rate reached 13 percent.

${ }^{29}$ These race/ethnicity groups are constructed such that Hispanic includes individuals of any race, while race groups include only non-Hispanic individuals.
} 
ing the recession and much of the recovery, effects on white workers' employment were less severe than those on workers of other races or ethnicities in absolute terms. Relative to mean outcomes, employment effects for Black workers are somewhat larger than for other groups during the depths of the recession, but by 2017, all groups employment effects had at least recovered to zero. As with the overall estimates, earnings have recovered less fully for all groups except Hispanic workers, whose earnings effects shrank to roughly zero in 2016. Earnings effects are generally not statistically distinguishable across groups. Point estimates for Asian workers suggest the effect of unemployment exposure on earnings has been worsening over time, but these estimates are not statistically significant due to lack of precision. For similar reasons, I do not discussion estimates by generation within race groups, though these estimates are presented in Appendix E for reference.

Members of different racial groups are not roughly evenly distributed across the country, so different groups may have been exposed to local unemployment shocks of different magnitudes, even if the responsiveness of employment and earnings to those shocks was similar. In fact, there are modest differences in the magnitudes of the unemployment shocks experienced by different race groups; White people experienced a 4.6 percentage point increase in unemployment between 2007 and 2009 on average, while that increase was 4.7 percentage points for Black people, 4.8 percentage points for Asian people, and nearly 4.9 percentage points for Hispanic people. Combining these differential shocks with the point estimates discussed above and mean earnings by group over this period suggests that recession exposure cost the average Black worker an amount equivalent to 12.1 percent of the average worker's total earnings between 2007 and 2017. This compares with 8.5 percent for White workers, 6.6 percent for Asian workers, and 6.2 percent for Hispanic workers. These losses also translate into 1.33 years of average earnings for Blacks, 0.94 years for Whites, 0.73 years for Asians, and 0.68 years for Hispanics.

\subsection{Effects on Places}

One way to mitigate adverse effects of a local unemployment shock is to migrate (Blanchard and Katz, 1992, Dao et al., 2017). If local unemployment shocks induce substantial migration, estimated effects on places could differ from effects on people. To investigate this possibility, I modify my baseline specification to use commuting zone fixed effects instead of person fixed effects and to allow recession exposure to vary as individuals move across commuting zones rather than fixing it 
based on their 2007 location. Formally, I estimate

$$
y_{i c t}=\sum_{t=2005}^{2017} \beta_{t} \text { Shock }_{c} \cdot 1[\text { Year }=t]+\sum_{a \in \text { ages }} \alpha_{a} \cdot 1\left[\text { Age }_{i t}=a\right]+\gamma_{c}+\delta_{t}+\varepsilon_{i c t}
$$

where $c$ now indexes commuting zones, $\gamma_{c}$ represents commuting zone fixed effects, and Shock $k_{c}=$ $U R_{c, 2009}-U R_{c, 2007}$ is the change in the unemployment rate between 2007 and 2009 in commuting zone $c$.

Figure 14 presents the $\beta_{t}$ coefficients from this specification, which I call place estimates, alongside the $\beta_{t}$ coefficients from my baseline specification, here referred to as person estimates. Overall, the trajectories of person and place estimates of the effects of recession exposure on employment and earnings are very similar. Where the two diverge, the person estimates are generally smaller in magnitude than the place estimates, though they generally fall within the confidence intervals of the place estimates. This suggests that there may have been some scope for workers to mitigate the effects of recession exposure by migrating, but overall workers fared roughly as well as the places where they lived at the beginning of the recession, even with the ability to move. This is consistent with direct estimates of effects of recession exposure on migration, which do not find evidence that people exposed to larger unemployment shocks were more likely to leave their 2007 commuting zone 30 To the extent that person and place estimates differ, the employment effects differ by more, suggesting that in this context it may have been easier to improve one's likelihood of being employed by moving than it was to improve one's earnings 31

\subsection{Effects of Increased Labor Market Concentration}

Might recession-related changes in the configuration of local labor markets also have effects on workers subsequent employment and earnings, above and beyond those associated with changes in labor demand? Job creation and destruction fell sharply during the Great Recession, establishment exit increased, and more productive continuing establishments grew faster (Foster et al., 2016). These recession-related dynamics may have combined to change the composition, structure, and degree of employment concentration in local labor markets substantially. Rinz (2018) shows that

\footnotetext{
${ }^{30}$ These estimates are presented in $\overline{\text { Appendix } \mathrm{F}}$

${ }^{31}$ Generation-specific estimates, also presented in Appendix F suggest that this is especially true of Baby Boomers.
} 
the local labor market concentration experienced by the average worker increased during the Great Recession. Specifically, the level of local industrial employment concentration experienced by the average worker, measured using an employment-based Herfindahl-Hirschman Index (HHI), increased from about 0.144 to 0.149 , an increase of about 3.5 percent. This is a substantially smaller shock than the more than 100 percent increase in unemployment over this period, but it represents a notable departure from decades of fairly consistent decline in this measure ${ }^{32}$ A growing literature documents a negative relationship between local labor market concentration and earnings (e.g. Azar et al. 2017; Benmelech et al. 2018; Rinz $\mid$ 2018; Berger et al. 2019; Qiu and Sojourner 2019; Jarosch et al. 2019: Prager and Schmitt 2019), but the relative importance of changes in concentration to the overall effects of exposure to the Great Recession is unknown 33

I construct local concentration shocks in a manner similar to the unemployment shocks used above. I use the HHI to measure local labor market concentration. Specifically, I define $H H I_{n}=$ $\sum_{f} s_{f}^{2}$ for each four-digit NAICS industry $n$ in each commuting zone using each firm $f$ share of total employment $s$. I then define $H H I_{c t}$ as the employment-weighted average of the industry-level HHIs for commuting zone $c$ in year $t$. My concentration shock measure, then, is HHIShock ${ }_{C Z 07(i)}=$ $\frac{D_{C Z 07(i)}}{\sigma_{D_{C Z 07(i)}}}$, where $D_{C Z 07(i)}=H H I_{C Z 07(i), 2009}-H H I_{C Z 07(i), 2007}$ and $C Z 07(i)$ gives individual $i$ 's commuting zone of residence in 2007. In words, this gives the change in HHI (in standard deviation

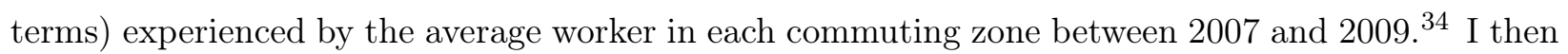
estimate

$$
\begin{aligned}
y_{i t}= & \sum_{t=2005}^{2017} \beta_{t} \text { HHIShock } \text { CZ07(i) }_{1} \cdot 1[\text { Year }=t]+\sum_{t=2005}^{2017} \zeta_{t} \text { Shock }_{C Z 07(i)} \cdot 1[\text { Year }=t]+ \\
& \sum_{t=2005}^{2017} \kappa_{t} \text { Bartik }_{C Z 07(i)} \cdot 1[\text { Year }=t]+\sum_{a \in \text { ages }} \alpha_{a} \cdot 1\left[\text { Age }_{i t}=a\right]+\gamma_{i}+\delta_{t}+\varepsilon_{i t}
\end{aligned}
$$

where Bartik $_{C Z 07(i)}$ is an industry-based, Bartik-style measure of predicted employment growth

\footnotetext{
${ }^{32}$ This pattern was also documented, roughly contemporaneously, by Lipsius (2018) and Rossi-Hansberg et al. (2018).

${ }^{33}$ These concentration shocks are also a new source of variation in the literature on local labor market concentration; recent studies have tended to utilize leave-one-out mean instruments, highly saturated OLS regressions, mergers, and structural modeling to study the relationship between concentration and earnings.

${ }^{34}$ Unlike the unemployment shock, the concentration shock is in standard deviation terms. I constructed the concentration shock this way because absolute changes in the HHI do not have the same intuitive interpretation as changes in the unemployment rate. This difference in construction should be kept in mind when comparing estimates across shocks.
} 
between 2007 and 2009 in individual $i$ 's commuting zone of residence in 2007. This measure is included here because the concentration shock is based on a local average of within-industry changes in concentration and could conceivably be capturing differences in sector-specific demand shocks across places 35 Other terms are defined as in Equation 1 above. For all shocks, the 2006 interaction is omitted, and all estimates are relative to that year.

Figure 15 shows estimated employment and earnings effects of exposure to concentration shocks for my full sample, estimated using Equation 4. Estimates of the effects of exposure to unemployment shocks from Equation 4 are also provided for reference. Both employment and earnings decline following exposure to a concentration shock, though these effects do not follow the same cyclical pattern as the effects of unemployment shocks. The onset of the effects of concentration shocks is slower, especially for earnings, and they are more persistent, showing little sign of recovery in recent years.

It is also worth noting that the magnitude of the earnings effects of exposure to an unemployment shock is substantially smaller when estimated alongside concentration and Bartik shocks than they are in Figure 3. Aside from this level difference, the pattern of earnings estimates is similar to the baseline specification. The employment effects estimated using Equation 4 are similar in magnitude during the recession and its immediate aftermath to those based on Equation 1, though they exhibit more recovery in more recent years. Given the relatively high correlation between the unemployment shocks and the Bartik shocks, it is unsurprising that including the Bartik shocks would change the estimated effects of the unemployment shocks. Overall, though, these estimates serve as evidence that the effects of exposure to unemployment shocks are robust to the inclusion of additional related shocks in the estimation 36

How do the effects of concentration shocks compare to the effects of unemployment shocks in terms of magnitude? One way to think about this is to put the unemployment rate shock estimates into standard deviation terms. This is an easy conversion; the standard deviation of the unemploy-

\footnotetext{
${ }^{35}$ In practice, the correlation between the concentration shock and the other shocks in this specification is low. The correlation between the concentration shock and the unemployment shock is 0.065 . The correlation between the concentration shock and the Bartik shock is 0.058. The unemployment shock and the Bartik shock are more strongly correlated (-0.62), which makes sense given the similarity between the underlying conditions they are measuring.

${ }^{36}$ When focusing on the effects of unemployment shocks on employment and earnings, I prefer estimates from Equation 1. In Equation 4 the Bartik shock measure is included to alleviate potential concerns about the mechanics of the HHI shock. Both the Bartik shock and the unemployment shock represent labor demand shocks in this equation, so the estimated effect of the unemployment shock is likely attenuated.
} 
ment shock across commuting zones is about two percentage points. Doubling the unemployment shock coefficients puts them roughly in standard deviation terms, making them comparably constructed to the concentration shock coefficients. This comparison indicates that employment and earnings are more responsive to unemployment shocks than they are to concentration shocks.

One might also compare the two types of shocks based on the consequences to the average worker of being exposed to each of them. The average worker was exposed to a 4.6 percentage point unemployment shock and a 0.2 standard deviation concentration shock. Using coefficients from Equation 4, this implies a total post-recession cost of exposure to the average unemployment shock equal to 6.3 percent of the average worker's total earnings. The cost of exposure to the average concentration shock is only about 0.1 percent of the average worker's total earnings. This reinforces the conclusion that the effects of unemployment shocks were felt more intensely during this period. Of course, the increase in local concentration during the recession was proportionally much smaller than the increase in unemployment.

Figures 16 and 17 show estimates of the effects of concentration shocks on employment and earnings by generation. In both cases, estimates indicate that younger workers are more adversely affected by concentration shocks than older workers. For earnings, estimates for Baby Boomers and the Silent Generation are in fact positive for all post-recession years, and they become statistically significant later in the period. Millennials and Gen-X see consistently negative and statistically significant earnings effects. For employment, effects are again consistently negative for Millennials and Gen-X, while estimates suggest little significant change for older workers.

Together, these estimates indicate that Great Recession-related concentration shocks have been harmful primarily to younger workers. Younger workers change jobs more often than older workers ${ }^{37}$ If these job transitions take place in an environment in which employers have stronger monopsony power due to increased concentration, younger workers may see smaller wage gains at each transition and end up earning less than they would have if concentration had been lower. Older workers may even stand to benefit from greater concentration if they are more likely to be incumbent at firms that become more profitable thanks to increased market power. In light of these differences across generations, it may be more informative to consider total earnings lost due to recession-related concentration shocks by generation. Using the same formulation as in the previous paragraph,

\footnotetext{
${ }^{37}$ For one illustration of this fact, see this tweet (Kimbrough, 2019).
} 
Millennials exposed to an average concentration shock lost 0.9 of their 2007 through 2017 earnings, while Gen-X lost 0.6 percent. Baby Boomers' earnings, on the other hand, increased 0.2 percent over this period due to concentration shocks, while Silent Generation workers gained 3.8 percent 38 These estimates, however, come with the caveat that the effects of concentration shocks have shown little evidence of abating, and the earnings effects appear to be increasing in magnitude over time. If this remains the case over longer horizons, concentration shocks could end up being more harmful to younger workers than the unemployment shocks, though the effects of concentration shocks would need to be very persistent for this to happen.

\section{Conclusion}

Local unemployment shocks associated with the Great Recession had adverse consequences for workers of all ages, but younger workers appear to have suffered the most persistent harms. Despite the fact that the employment rates of Millennials and Gen-X are no longer significantly depressed due to these shocks, their earnings have shown little sign of recovering. For Millennials specifically, my estimates indicate that recession exposure reduced educational attainment and made them less likely to work for high-paying employers, two effects that may combine to drive this divergence between the trajectories of their employment and earnings recoveries. The fact that Millennials continue to work for lower-paying employers than they otherwise would have indicates that this group in particular may have been knocked off the job ladder during the Great Recession, or that it has not fully resumed functioning for them during the recovery (Moscarini and Postel-Vinay, 2016). As discussed above, this is consistent with the literature on "scarring" in the labor market which suggests that worse initial employment opportunities drive long-term consequences of entering the labor market during a downturn and provides reason to believe these earnings losses could persist in the even-longer run. Here, persistent reductions in working for high-paying employers are primarily observed among younger workers; this dynamic may be specific to conditions at labor market entry.

Shocks to local labor market concentration during the Great Recession also reduced younger workers earnings, even conditioning on unemployment shocks and a Bartik-style labor demand shock. Though smaller in magnitude than the effects of unemployment shocks and realized more

\footnotetext{
${ }^{38}$ The corresponding earnings changes due to unemployment shocks in this specification are -9.9 percent for Millennials, -6.0 percent for Gen-X, -6.1 percent for Baby Boomers, and +7.0 percent for the Silent Generation.
} 
gradually, the effects of concentration shocks appear to be even more persistent and, if anything, to have grown more negative over time. The story of the labor market recovery from the Great Recession is not just about overcoming a huge demand shock; changes in market structure matter, too.

These estimates have implications for how the government might best respond to future recessions. Unemployment insurance (UI) is the primary form of assistance provided to workers who lose jobs and is intended to provide some financial security while they look for jobs that best match their skills and preferences. Even though UI benefits were extended substantially during the Great Recession, eligibility requirements that excluded new entrants from receiving them remained in place. Is it a coincidence, then, that younger workers, who were less likely to have the prior work experience that would make them eligible for UI, still saw recession exposure reduce their likelihood of working for high-paying employers in 2017, ten years after the recession began? And if recession-related changes in market structure are reducing younger workers earnings and making them less likely to be employed, could the structure or value of UI benefits adjust to mitigate these effects? Might some other form of assistance be necessary to improve workers subsequent earnings and employment outcomes in the face of these changes in the labor market? I leave these questions to future research. 


\section{References}

Abowd, J. M., Kramarz, F., and Margolis, D. N. (1999). High wage workers and high wage firms. Econometrica, 67(2):251-333.

Azar, J., Marinescu, I., and Steinbaum, M. I. (2017). Labor market concentration. NBER Working Paper No. 24147.

Beaudry, P. and DiNardo, J. (1991). The effect of implicit contracts on the movement of wages over the business cycle: Evidence from micro data. Journal of Political Economy, 99(4):665-688.

Benmelech, E., Bergman, N., and Kim, H. (2018). Strong employers and weak employees: How does employer concentration affect wages? NBER Working Paper No. 24307.

Berger, D. W., Herkenhoff, K. F., and Mongey, S. (2019). Labor market power. NBER Working Paper No. 25719.

Blanchard, O. J. and Katz, L. F. (1992). Regional evolutions. Brookings Papers on Economic Activity, 1992(1):1-75.

Dao, M., Furceri, D., and Loungani, P. (2017). Regional labor market adjustment in the United States: trend and cycle. Review of Economics and Statistics, 99(2):243-257.

Davis, S. J. and Von Wachter, T. M. (2011). Recessions and the cost of job loss. Brookings Papers on Economic Activity, 43(2):1-72.

Dimock, M. (2019). Defining generations: Where Millennials end and Generation Z begins.

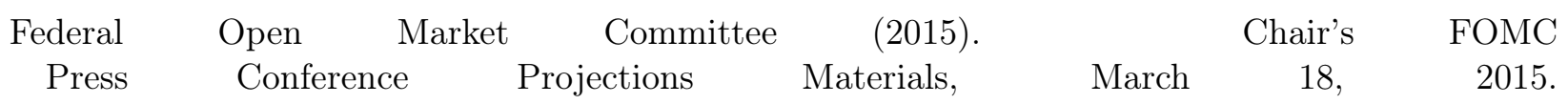
https://www.federalreserve.gov/monetarypolicy/files/fomcprojtabl20150318.pdf

Foster, L., Grim, C., and Haltiwanger, J. (2016). Reallocation in the great recession: cleansing or not? Journal of Labor Economics, 34(S1):S293-S331.

Hershbein, B. J. (2012). Graduating high school in a recession: Work, education, and home production. The BE Journal of Economic Analysis 8 Policy, 12(1).

Jacobson, L. S., LaLonde, R. J., and Sullivan, D. G. (1993). Earnings losses of displaced workers. The American Economic Review, 83(4):685-709.

Jarosch, G. (2015). Searching for job security and the consequences of job loss. Working paper.

Jarosch, G., Nimczik, J. S., and Sorkin, I. (2019). Granular search, market structure, and wages. https://sites.google.com/site/isaacsorkin/jns ${ }_{g}$ ranular.pdf $?$ attredirects $=0$.

Kahn, L. B. (2010). The long-term labor market consequences of graduating from college in a bad economy. Labour Economics, 17(2):303-316.

Kimbrough, G. (2019). Let's be clear: millennials are not "job hopping"... Tweet. https://twitter.com/graykimbrough/status/1089347497569513472?s=21.

Krueger, A. B. (2015). How tight is the labor market? The 2015 Martin Feldstein Lecture, National Bureau of Economic Research. https://www.nber.org/reporter/2015number3/ 
Lipsius, B. (2018). Labor market concentration does not explain the falling labor share. https://ideas.repec.org/p/jmp/jm2018/pli1202.html.

Moscarini, G. and Postel-Vinay, F. (2016). Did the job ladder fail after the Great Recession? Journal of Labor Economics, 34(S1):S55-S93.

Neal, D. (1995). Industry-specific human capital: Evidence from displaced workers. Journal of Labor Economics, 13(4):653-677.

Oreopoulos, P., Von Wachter, T., and Heisz, A. (2012). The short-and long-term career effects of graduating in a recession. American Economic Journal: Applied Economics, 4(1):1-29.

Prager, E. and Schmitt, M. (2019). Employer consolidation and wages: Evidence from hospitals. Working paper.

Qiu, Y. and Sojourner, A. J. (2019). Labor market concentration and labor compensation. http://dx.doi.org/10.2139/ssrn.3312197.

Rinz, K. (2018). Labor market concentration, earnings inequality, and earnings mobility. CARRA Working Paper 2018-10.

Rossi-Hansberg, E., Sarte, P.-D., and Trachter, N. (2018). Diverging trends in national and local concentration. NBER Working Paper No. 25066.

Rothstein, J. (2019). The lost generation? Scarring after the Great Recession. Working Paper.

Ruhm, C. J. (1991). Are workers permanently scarred by job displacements? The American Economic Review, 81(1):319-324.

Schmeider, J. F., von Wachter, T., and Heining, J. (2018). The costs of job displacement over the business cycle and its sources: Evidence from Germany. Working Paper.

Schwandt, H. and Von Wachter, T. (2019). Unlucky cohorts: Estimating the long-term effects of entering the labor market in a recession in large cross-sectional data sets. Journal of Labor Economics, 37(S1):S161-S198.

Stuart, B. A. (2019). The long-run effects of recessions on education and income. Working Paper.

Sullivan, D. and Von Wachter, T. (2009). Job displacement and mortality: An analysis using administrative data. The Quarterly Journal of Economics, 124(3):1265-1306.

Topel, R. (1990). Specific capital and unemployment: Measuring the costs and consequences of job loss. In Carnegie-Rochester Conference Series on Public Policy, volume 33, pages 181-214. Elsevier.

Topel, R. H. and Ward, M. P. (1992). Job mobility and the careers of young men. The Quarterly Journal of Economics, 107(2):439-479.

Von Wachter, T., Song, J., and Manchester, J. (2009). Long-term earnings losses due to mass layoffs during the 1982 recession: An analysis using US administrative data from 1974 to 2004.

Wagner, D. and Layne, M. (2014). The Person Identification Validation System (PVS): Applying the Center for Administrative Records Research and Applications' (CARRA) Record Linkage Software. CARRA Working Paper No. 2014-01. 
Yagan, D. (2018). Employment 'hysteresis' from the Great Recession. Forthcoming, Journal of Political Economy. 


\section{Tables}

Table 1: Individual-Level Summary Statistics, Analysis Sample

\begin{tabular}{|c|c|c|c|c|c|}
\hline VARIABLES & $\begin{array}{l}(1) \\
\text { All }\end{array}$ & $\begin{array}{c}(2) \\
\text { Millennials } \\
\end{array}$ & $\begin{array}{c}(3) \\
\text { Generation X }\end{array}$ & $\begin{array}{c}(4) \\
\text { Baby } \\
\text { Boomers }\end{array}$ & $\begin{array}{c}(5) \\
\text { Silent } \\
\text { Generation }\end{array}$ \\
\hline Age in 2005 (years) & $\begin{array}{c}37.4 \\
(17.3)\end{array}$ & $\begin{array}{l}16.4 \\
(4.6)\end{array}$ & $\begin{array}{c}32.6 \\
(4.7)\end{array}$ & $\begin{array}{l}49.4 \\
(5.4)\end{array}$ & $\begin{array}{c}66.4 \\
(4.8)\end{array}$ \\
\hline Male & $\begin{array}{c}48.5 \\
(49.9)\end{array}$ & $\begin{array}{c}50.4 \\
(49.9)\end{array}$ & $\begin{array}{c}49.0 \\
(50.0)\end{array}$ & $\begin{array}{c}48.1 \\
(50.0)\end{array}$ & $\begin{array}{c}43.9 \\
(49.6)\end{array}$ \\
\hline Female & $\begin{array}{c}51.5 \\
(49.9)\end{array}$ & $\begin{array}{c}49.6 \\
(49.9)\end{array}$ & $\begin{array}{c}51.0 \\
(50.0)\end{array}$ & $\begin{array}{c}51.9 \\
(50.0)\end{array}$ & $\begin{array}{c}56.1 \\
(49.6)\end{array}$ \\
\hline White, non-Hispanic & $\begin{array}{c}68.0 \\
(46.7)\end{array}$ & $\begin{array}{c}61.3 \\
(48.7)\end{array}$ & $\begin{array}{c}64.4 \\
(47.9)\end{array}$ & $\begin{array}{c}73.1 \\
(44.4)\end{array}$ & $\begin{array}{c}78.7 \\
(40.9)\end{array}$ \\
\hline Black, non-Hispanic & $\begin{array}{c}11.6 \\
(32.1)\end{array}$ & $\begin{array}{c}14.4 \\
(35.0)\end{array}$ & $\begin{array}{l}12.0 \\
(32.5)\end{array}$ & $\begin{array}{l}10.1 \\
(30.2)\end{array}$ & $\begin{array}{c}7.9 \\
(26.9)\end{array}$ \\
\hline Asian, non-Hispanic & $\begin{array}{c}4.6 \\
(20.9)\end{array}$ & $\begin{array}{c}4.2 \\
(20.0)\end{array}$ & $\begin{array}{c}5.6 \\
(23.0)\end{array}$ & $\begin{array}{c}4.3 \\
(20.3)\end{array}$ & $\begin{array}{c}3.8 \\
(19.2)\end{array}$ \\
\hline Hispanic & $\begin{array}{c}11.9 \\
(32.3)\end{array}$ & $\begin{array}{c}15.7 \\
(36.3)\end{array}$ & $\begin{array}{c}13.3 \\
(34.0)\end{array}$ & $\begin{array}{c}9.1 \\
(28.8)\end{array}$ & $\begin{array}{c}6.9 \\
(25.4)\end{array}$ \\
\hline Other race, non-Hispanic & $\begin{array}{c}1.3 \\
(11.5)\end{array}$ & $\begin{array}{c}1.7 \\
(12.9)\end{array}$ & $\begin{array}{c}1.4 \\
(11.8)\end{array}$ & $\begin{array}{c}1.2 \\
(10.8)\end{array}$ & $\begin{array}{c}0.8 \\
(8.9)\end{array}$ \\
\hline Employed in 2005 & $\begin{array}{c}66.1 \\
(47.3)\end{array}$ & $\begin{array}{c}44.5 \\
(49.7)\end{array}$ & $\begin{array}{c}84.6 \\
(36.1)\end{array}$ & $\begin{array}{c}78.6 \\
(41.0)\end{array}$ & $\begin{array}{c}40.8 \\
(49.2)\end{array}$ \\
\hline Total compensation in 2005 (thousands of $2017 \$$ ) & $\begin{array}{c}30.6 \\
(116.5)\end{array}$ & $\begin{array}{c}5.8 \\
(13.5)\end{array}$ & $\begin{array}{c}38.9 \\
(87.8)\end{array}$ & $\begin{array}{c}49.3 \\
(158.0)\end{array}$ & $\begin{array}{c}19.5 \\
(159.7)\end{array}$ \\
\hline Filed/claimed on 1040 in 2005 & $\begin{array}{c}91.7 \\
(27.6)\end{array}$ & $\begin{array}{c}93.9 \\
(23.8)\end{array}$ & $\begin{array}{c}91.8 \\
(27.4)\end{array}$ & $\begin{array}{c}91.7 \\
(27.7)\end{array}$ & $\begin{array}{c}85.9 \\
(34.8)\end{array}$ \\
\hline Employed in 2017 & $\begin{array}{c}66.5 \\
(47.3)\end{array}$ & $\begin{array}{c}86.0 \\
(34.7)\end{array}$ & $\begin{array}{c}80.7 \\
(39.5)\end{array}$ & $\begin{array}{c}57.0 \\
(49.5)\end{array}$ & $\begin{array}{c}11.3 \\
(31.7)\end{array}$ \\
\hline Total compensation in 2017 (thousands of $2017 \$$ ) & $\begin{array}{c}36.2 \\
(150.0)\end{array}$ & $\begin{array}{c}32.1 \\
(126.2)\end{array}$ & $\begin{array}{c}54.2 \\
(139.3)\end{array}$ & $\begin{array}{c}36.5 \\
(192.9)\end{array}$ & $\begin{array}{c}3.7 \\
(49.9)\end{array}$ \\
\hline Filed/claimed on 1040 in 2017 & $\begin{array}{c}85.2 \\
(35.5)\end{array}$ & $\begin{array}{c}88.7 \\
(31.7)\end{array}$ & $\begin{array}{c}87.5 \\
(33.1)\end{array}$ & $\begin{array}{c}84.7 \\
(36.0)\end{array}$ & $\begin{array}{c}72.8 \\
(44.5)\end{array}$ \\
\hline Millennial (born 1981-1996) & $\begin{array}{c}28.7 \\
(45.3)\end{array}$ & & & & \\
\hline Generation X (born 1965-1980) & $\begin{array}{c}27.0 \\
(44.5)\end{array}$ & & & & \\
\hline Baby Boomer (born 1946-1964) & $\begin{array}{c}32.8 \\
(46.9)\end{array}$ & & & & \\
\hline Silent Generation (born 1928-1945) & $\begin{array}{c}11.5 \\
(31.9)\end{array}$ & & & & \\
\hline Observations & $4,121,000$ & $1,184,000$ & $1,113,000$ & $1,350,000$ & 474,000 \\
\hline
\end{tabular}

Source: Form 1040, Form W-2, Census Numident, American Community Survey (2001 through 2017), Decennial Census (2000 and 2010)

Note: Standard deviations, reported in parentheses, are reconstructed from rounded standard errors and sample sizes. Each individual in sample is counted once in this table. Sample sizes are rounded for disclosure avoidance purposes. Release authorization number CBDRB-FY19-376. 


\section{Figures}

Figure 1: Employment and Earnings Trends, by Generation
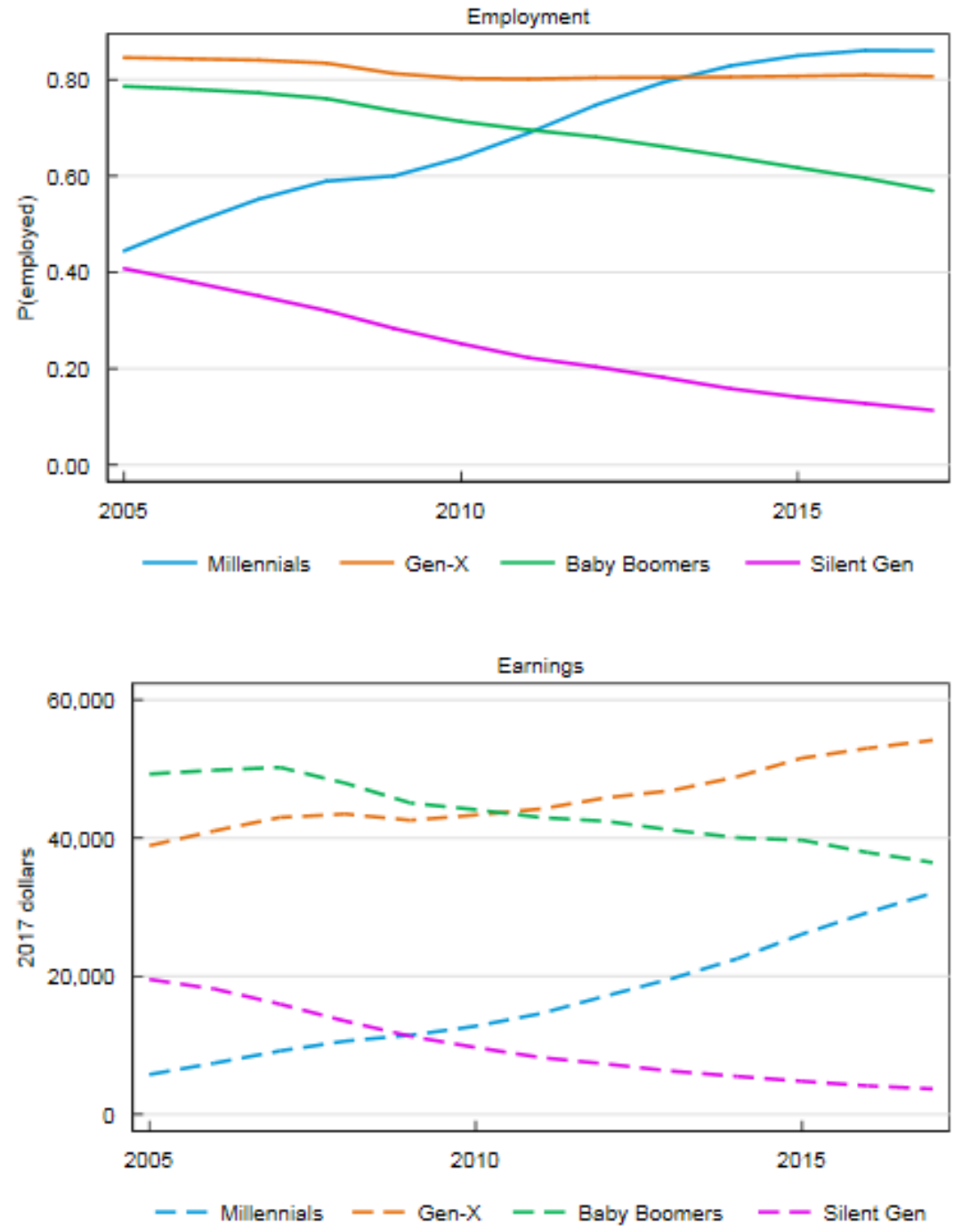

Source: Form W-2, Census Numident. Release authorization number CBDRB-FY19-376.

Note: Individuals are employed if they have any W-2 earnings in a given year. Earnings include wage and salary income as well as deferred compensation. 
Figure 2: Effects of Local Unemployment Shocks on Employment and Earnings, 1957-1976 Birth Cohorts
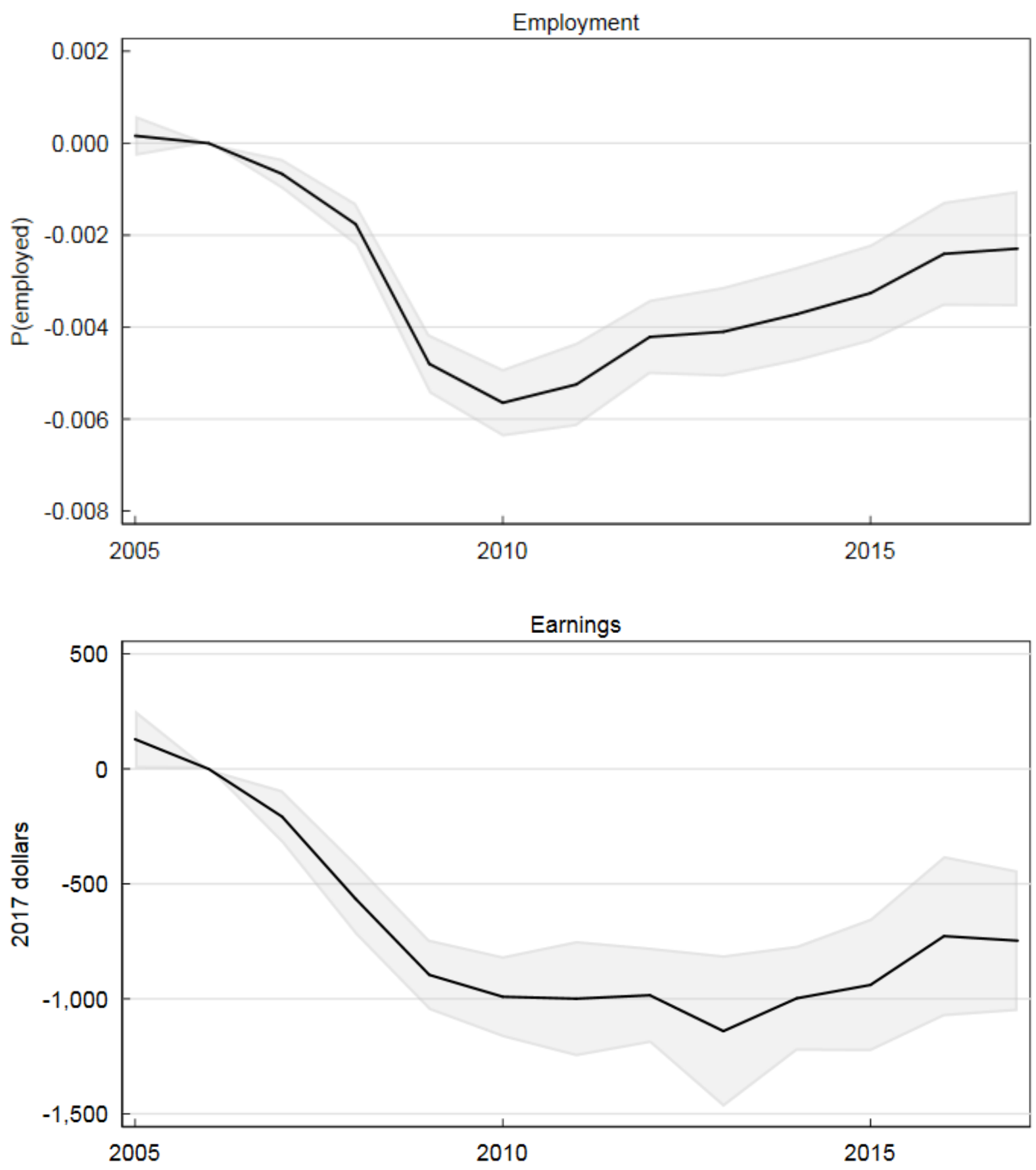

Source: Form 1040, Form 1099, Form W-2, Census Numident, American Community Survey (2001 through 2017), Decennial Census (2000 and 2010), MAF-ARF. Release authorization number CBDRB-FY19-376.

Note: Points plotted are $\beta$ coefficients as estimated in Equation 1 Shaded regions represent 95 percent confidence intervals. 
Figure 3: Effects of Local Unemployment Shocks on Employment and Earnings Effects, 1928-1996 Birth Cohorts
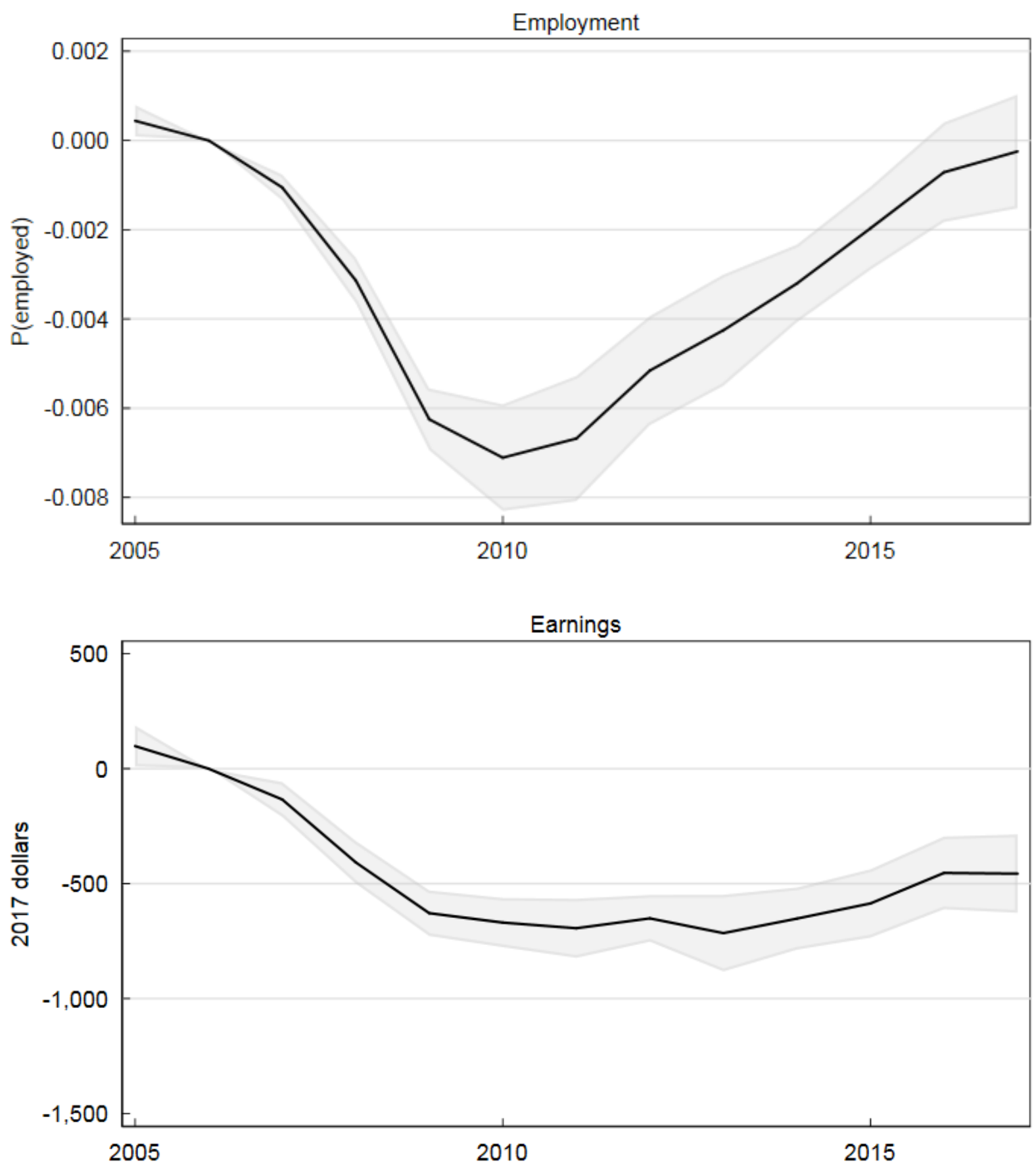

Source: Form 1040, Form 1099, Form W-2, Census Numident, American Community Survey (2001 through 2017), Decennial Census (2000 and 2010), MAF-ARF. Release authorization number CBDRB-FY19-376.

Note: Points plotted are $\beta$ coefficients as estimated in Equation 1 Shaded regions represent 95 percent confidence intervals. 
Figure 4: Effects of Local Unemployment Shocks on Employment, by Generation
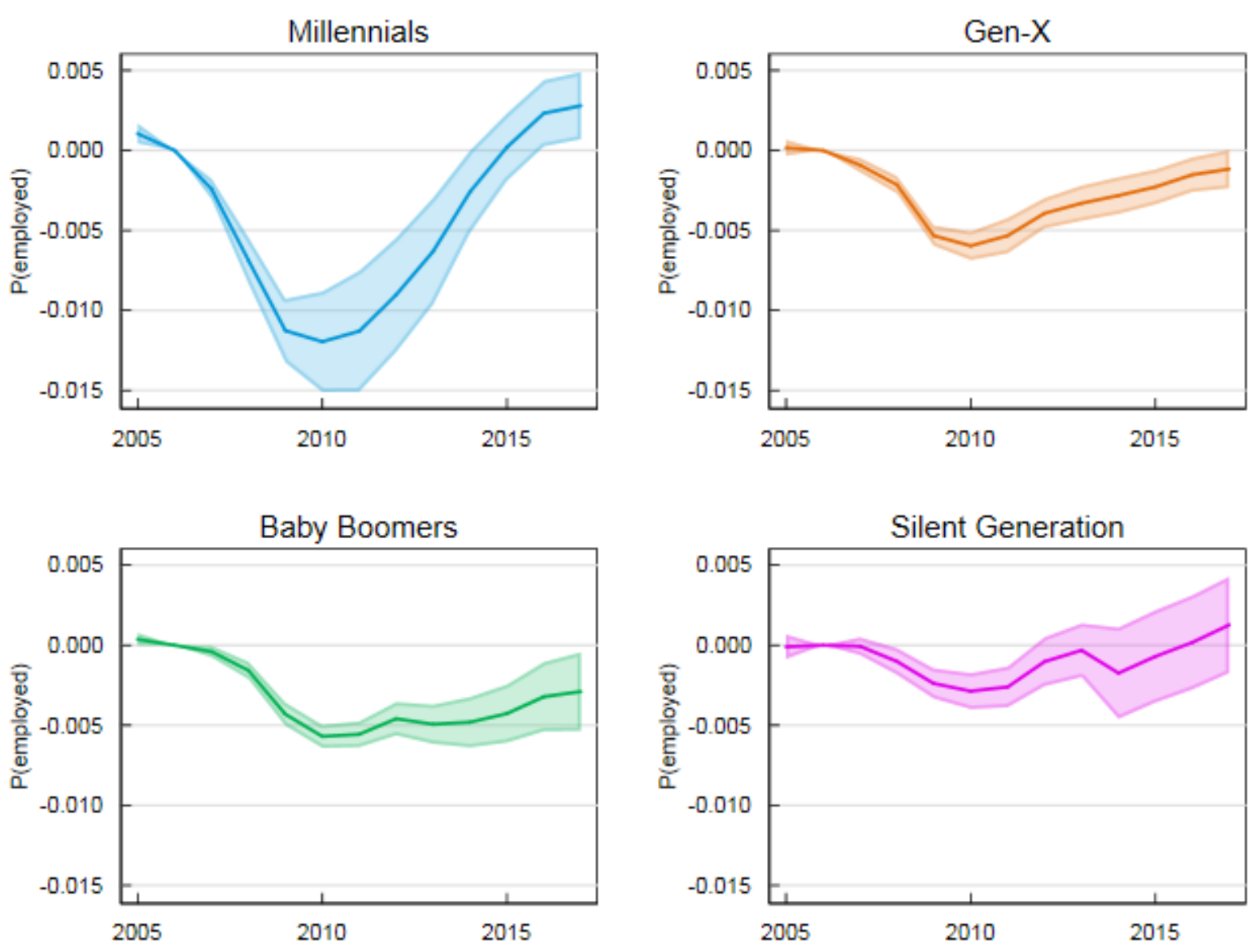

Source: Form 1040, Form 1099, Form W-2, Census Numident, American Community Survey (2001 through 2017), Decennial Census (2000 and 2010), MAF-ARF. Release authorization number CBDRB-FY19-376.

Note: Points plotted are $\beta$ coefficients as estimated in Equation 1. Shaded regions represent 95 percent confidence intervals. 
Figure 5: Effects of Local Unemployment Shocks on Earnings, by Generation
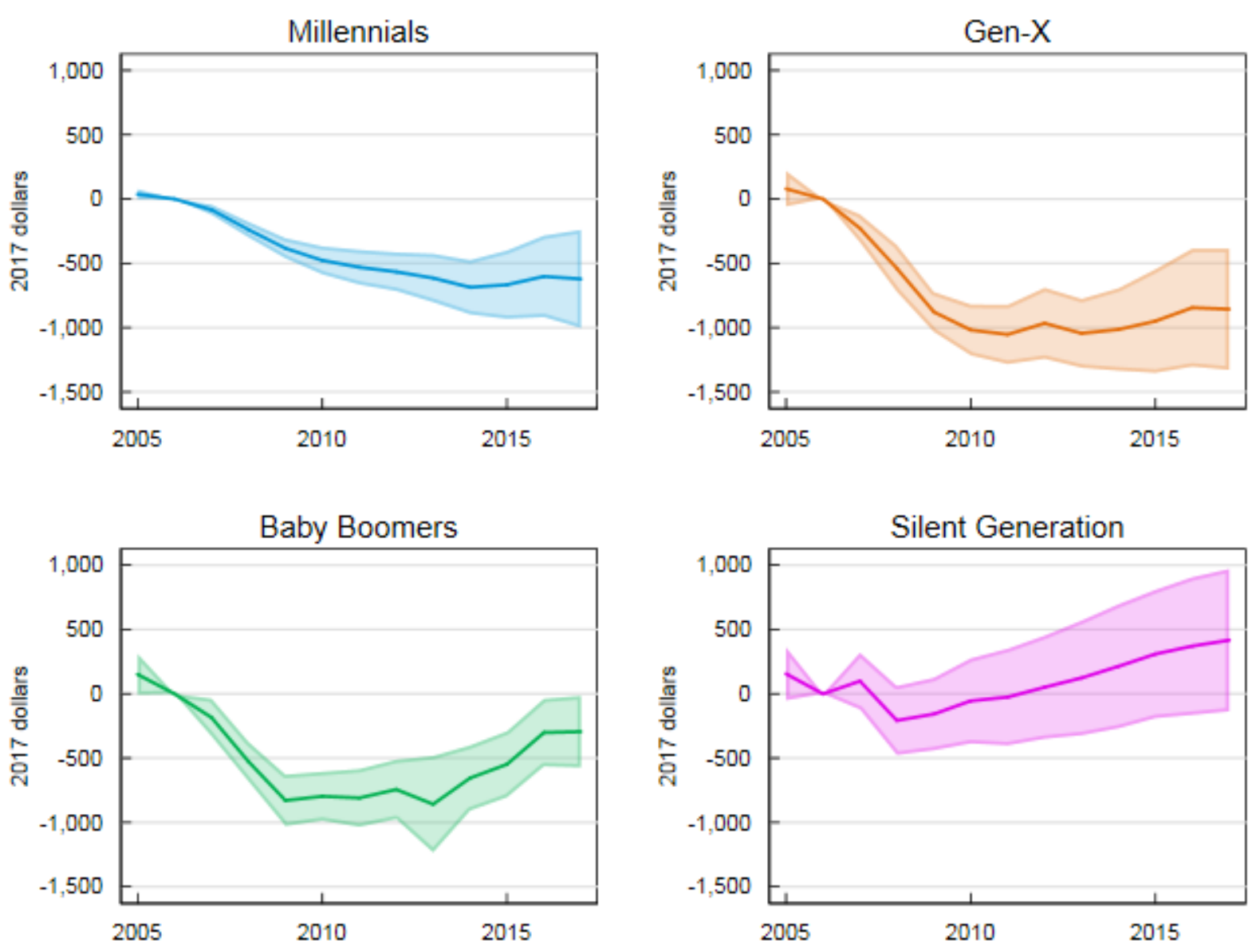

Source: Form 1040, Form 1099, Form W-2, Census Numident, American Community Survey (2001 through 2017), Decennial Census (2000 and 2010), MAF-ARF. Release authorization number CBDRB-FY19-376.

Note: Points plotted are $\beta$ coefficients as estimated in Equation 1. Shaded regions represent 95 percent confidence intervals. 
Figure 6: Effects of Local Unemployment Shocks on Probability of Working for a High-Paying Employer (Top Quartile), by Generation
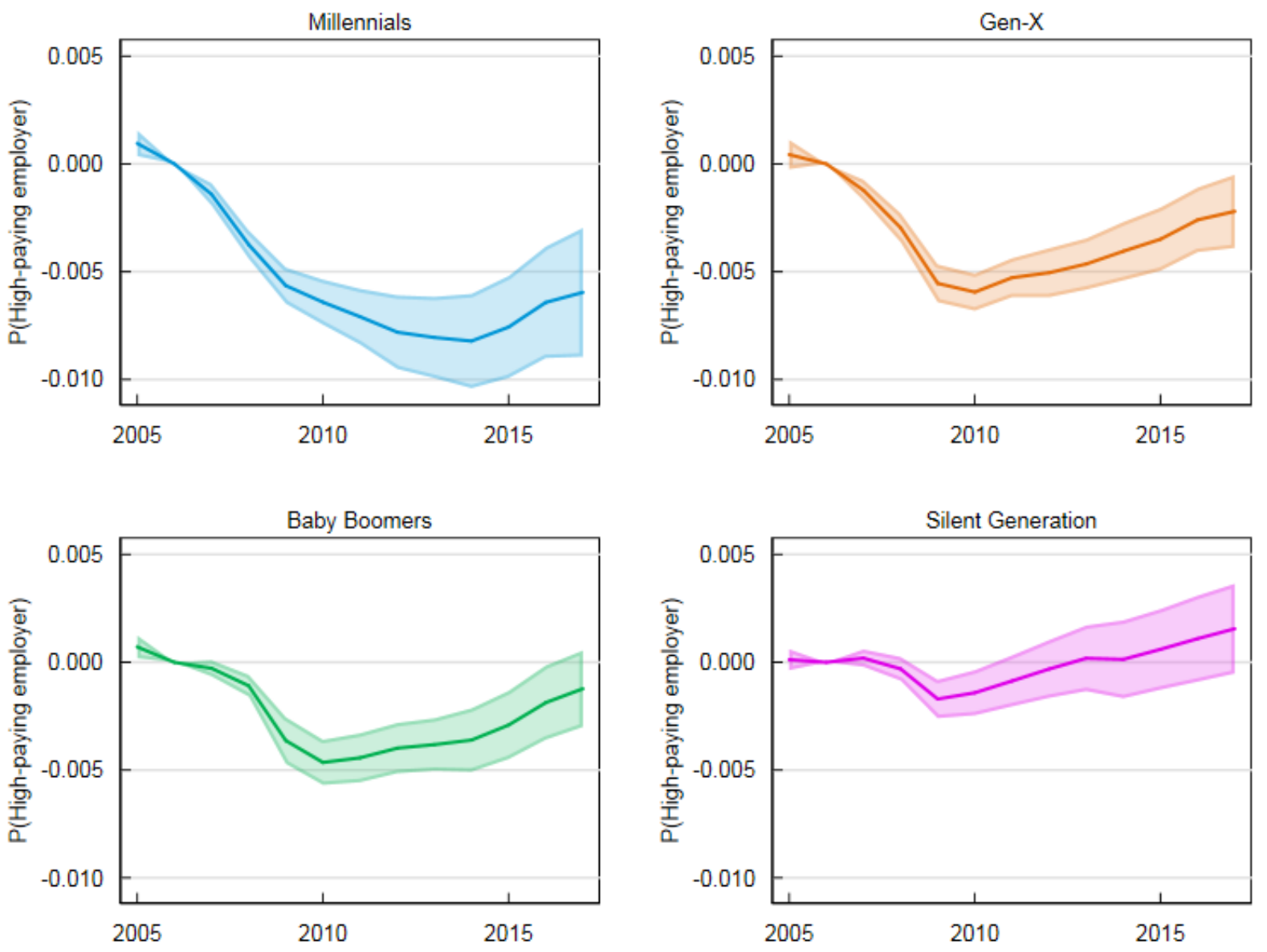

Source: Form 1040, Form 1099, Form W-2, Census Numident, American Community Survey (2001 through 2017), Decennial Census (2000 and 2010). Release authorization number CBDRB-FY19-500.

Note: Points plotted are $\beta$ coefficients as estimated in Equation 1. Shaded regions represent 95 percent confidence intervals. 
Figure 7: Effects of Local Unemployment Shocks on Millennials' Educational Attainment

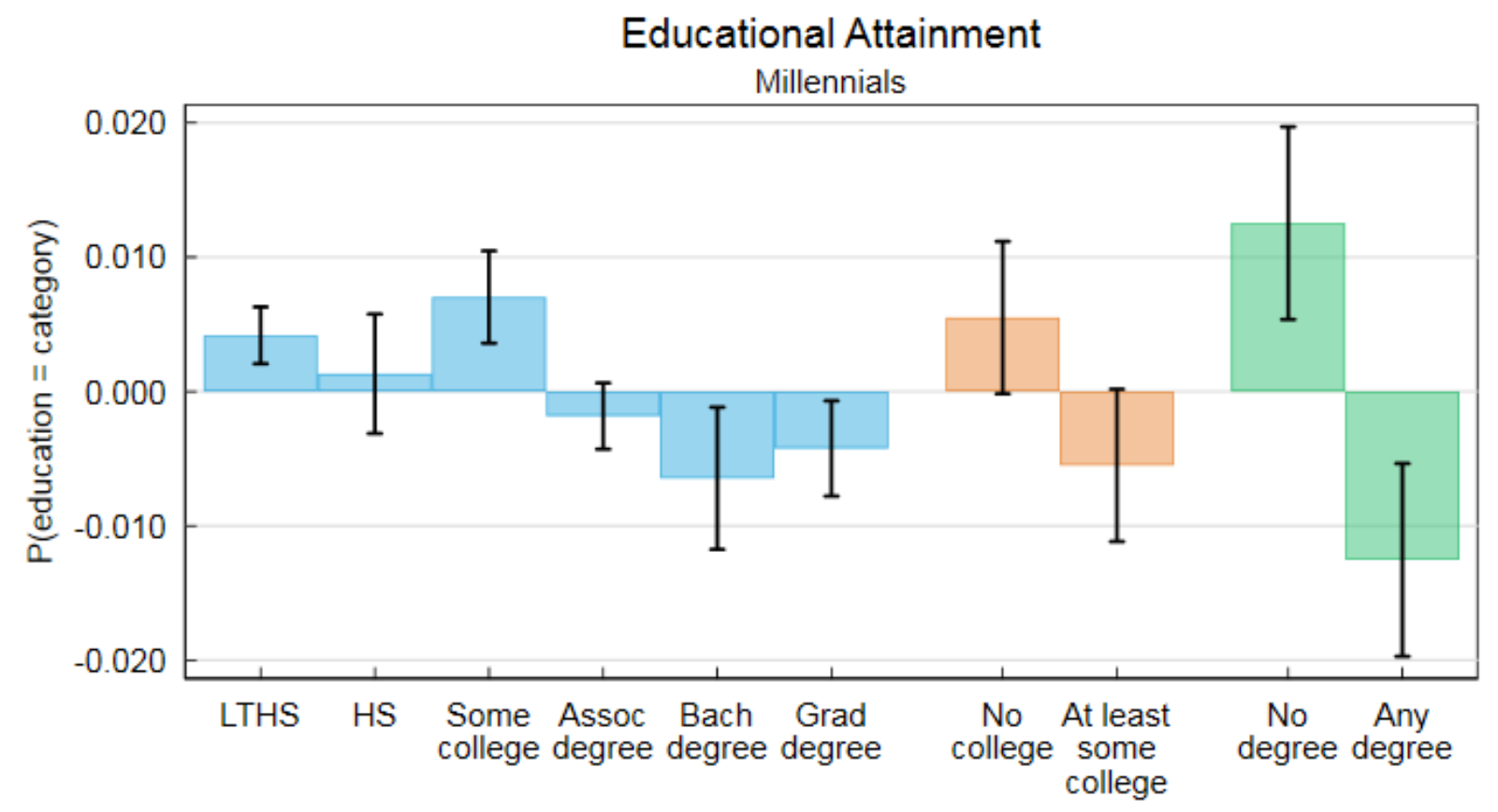

Source: Form 1040, Form 1099, Form W-2, Census Numident, American Community Survey (2001 through 2017), Decennial Census (2000 and 2010), MAF-ARF. Release authorization number CBDRB-FY19-376.

Note: Points plotted are $\beta$ coefficients as estimated in Equation 2 Black lines represent 95 percent confidence intervals. 
Figure 8: Effects of Local Unemployment Shocks on Earnings, by Displacement Status
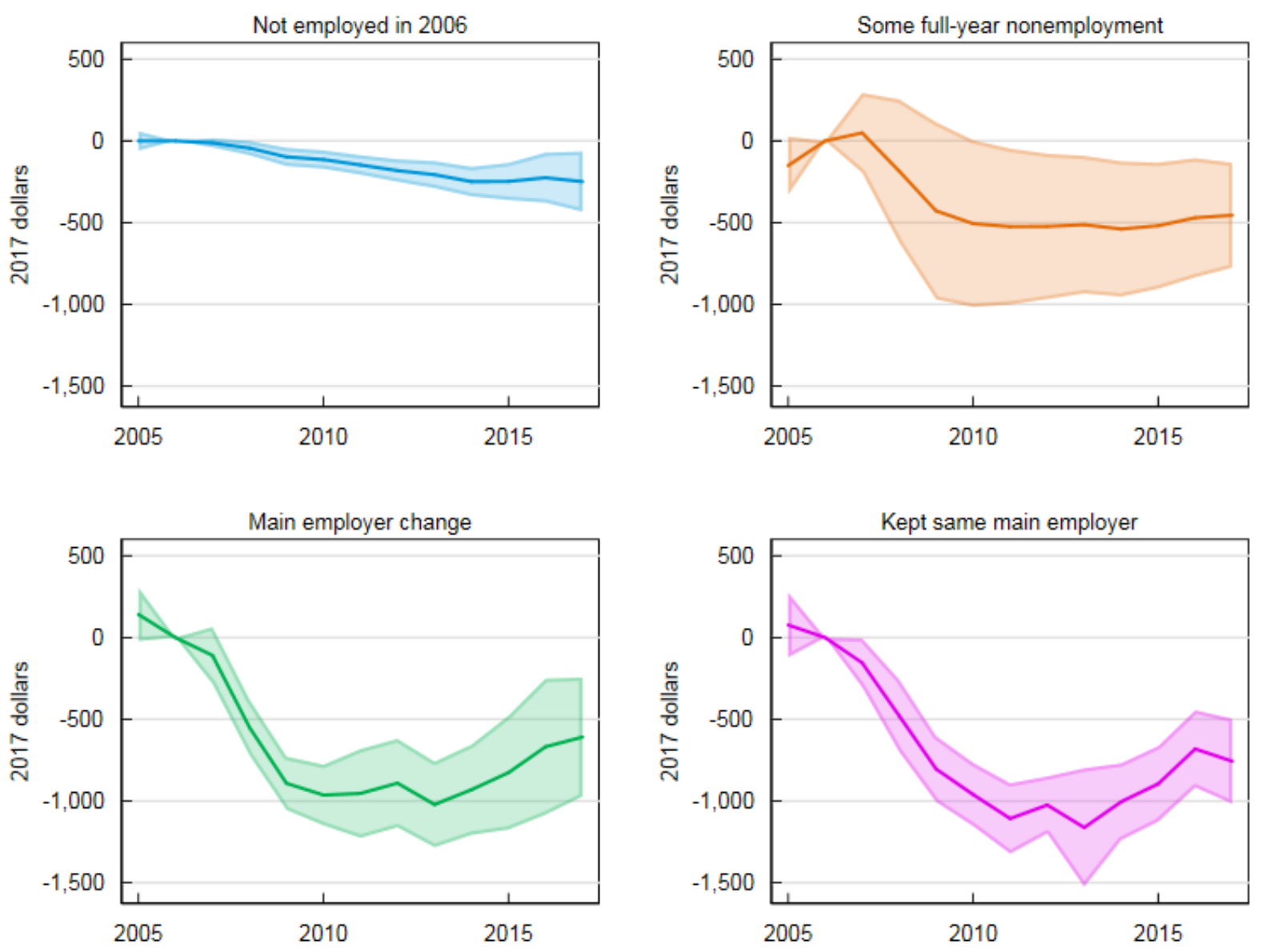

Source: Form 1040, Form 1099, Form W-2, Census Numident, American Community Survey (2001 through 2017), Decennial Census (2000 and 2010), MAF-ARF. Release authorization number CBDRB-FY19-431.

Note: Points plotted are $\beta$ coefficients as estimated in Equation 1. Shaded regions represent 95 percent confidence intervals. 
Figure 9: Effects of Local Unemployment Shocks on Employment and Earnings, 1928-1996 Birth Cohorts, by Gender
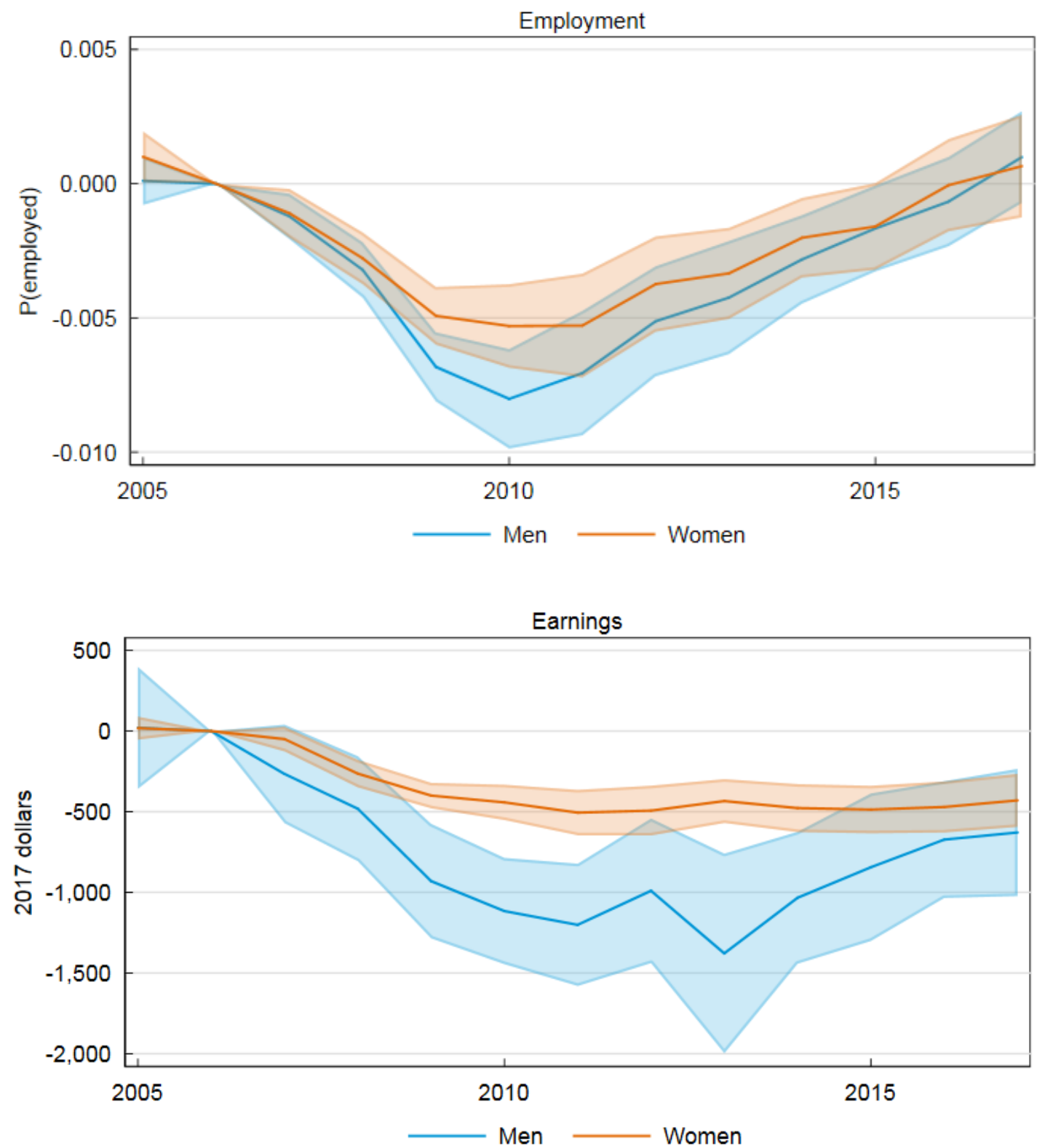

Source: Form 1040, Form 1099, Form W-2, Census Numident, American Community Survey (2001 through 2017), Decennial Census (2000 and 2010), MAF-ARF. Release authorization number CBDRB-FY19-376.

Note: Points plotted are $\beta$ coefficients as estimated in Equation 1 Shaded regions represent 95 percent confidence intervals. 
Figure 10: Effects of Local Unemployment Shocks on Employment, by Gender and Generation
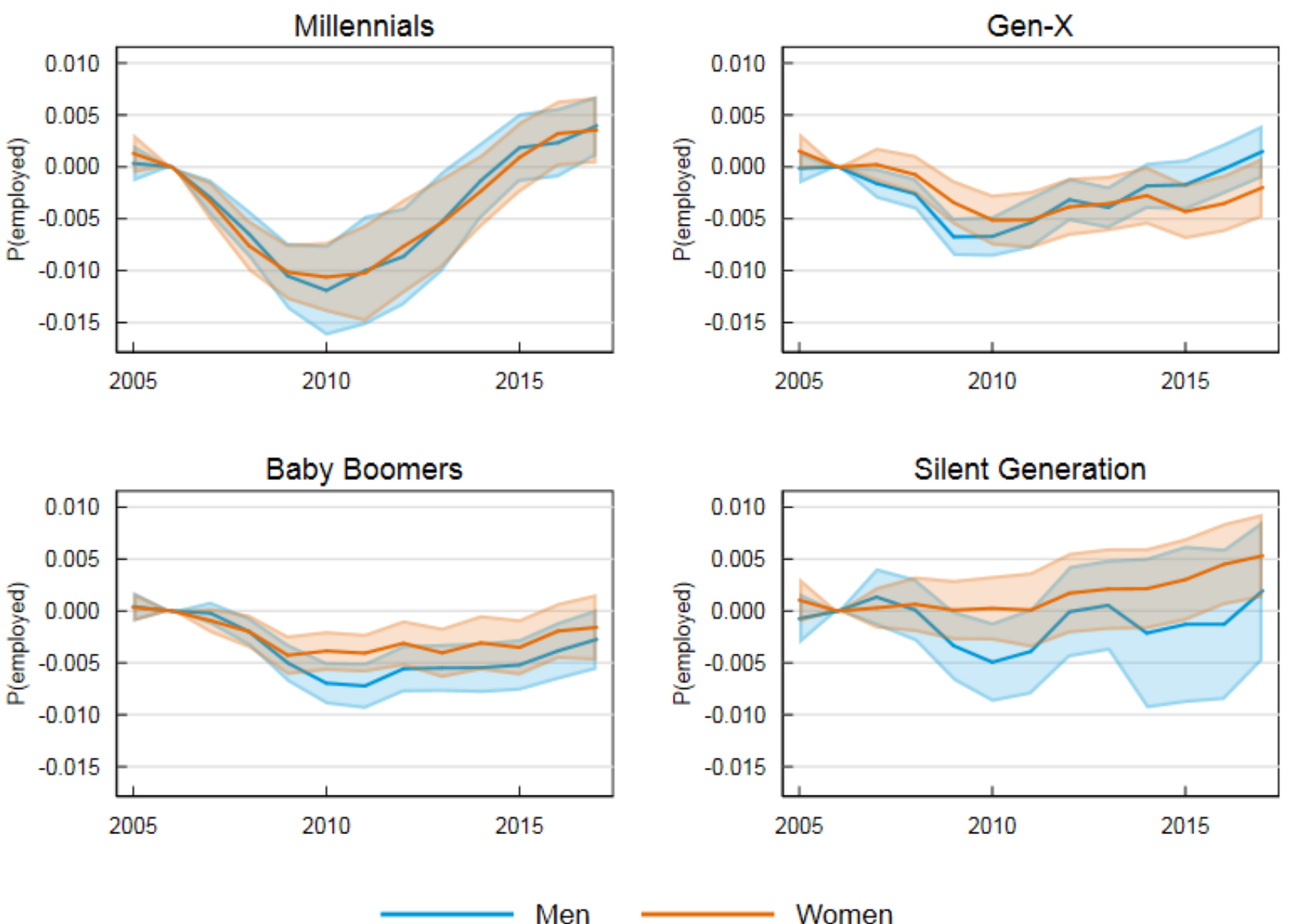

Source: Form 1040, Form 1099, Form W-2, Census Numident, American Community Survey (2001 through 2017), Decennial Census (2000 and 2010), MAF-ARF. Release authorization number CBDRB-FY19-376.

Note: Points plotted are $\beta$ coefficients as estimated in Equation 1. Shaded regions represent 95 percent confidence intervals. 
Figure 11: Effects of Local Unemployment Shocks on Earnings, by Gender and Generation
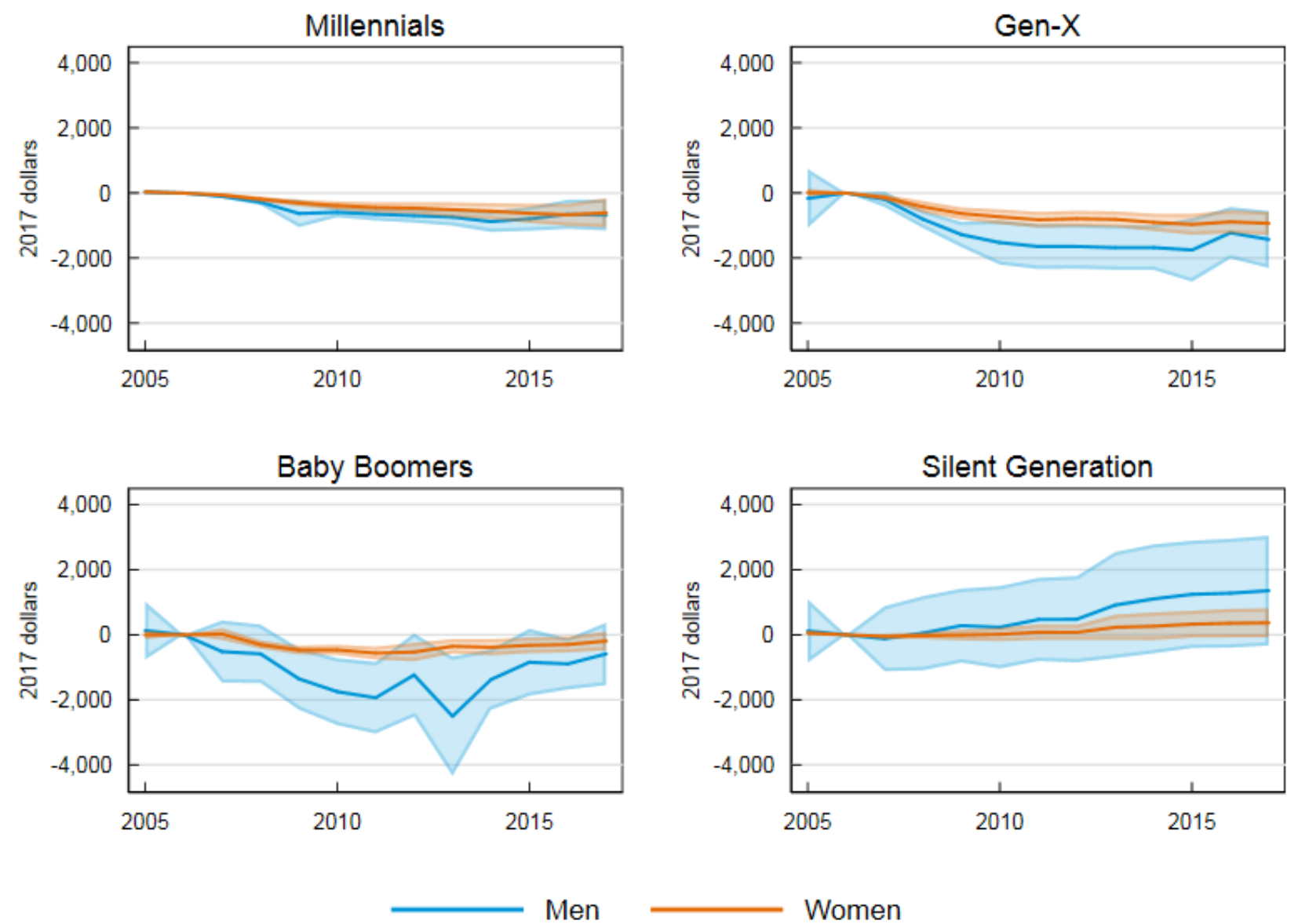

Source: Form 1040, Form 1099, Form W-2, Census Numident, American Community Survey (2001 through 2017), Decennial Census (2000 and 2010), MAF-ARF. Release authorization number CBDRB-FY19-376.

Note: Points plotted are $\beta$ coefficients as estimated in Equation 1. Shaded regions represent 95 percent confidence intervals. 
Figure 12: Effects of Local Unemployment Shocks on Employment, by Race
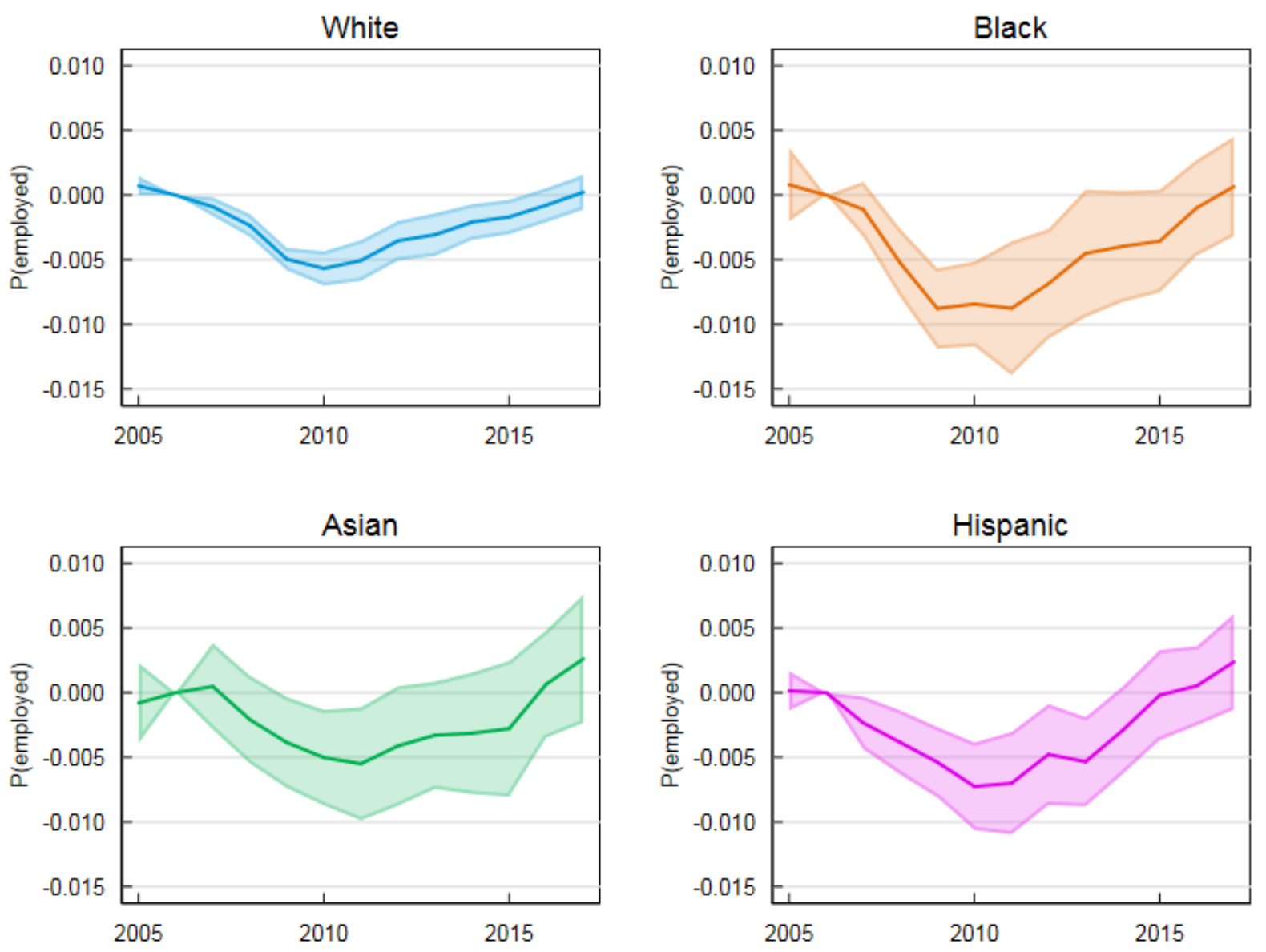

Source: Form 1040, Form 1099, Form W-2, Census Numident, American Community Survey (2001 through 2017), Decennial Census (2000 and 2010), MAF-ARF. Release authorization number CBDRB-FY19-376.

Note: Points plotted are $\beta$ coefficients as estimated in Equation 1. Shaded regions represent 95 percent confidence intervals. 
Figure 13: Effects of Local Unemployment Shocks on Earnings, by Race
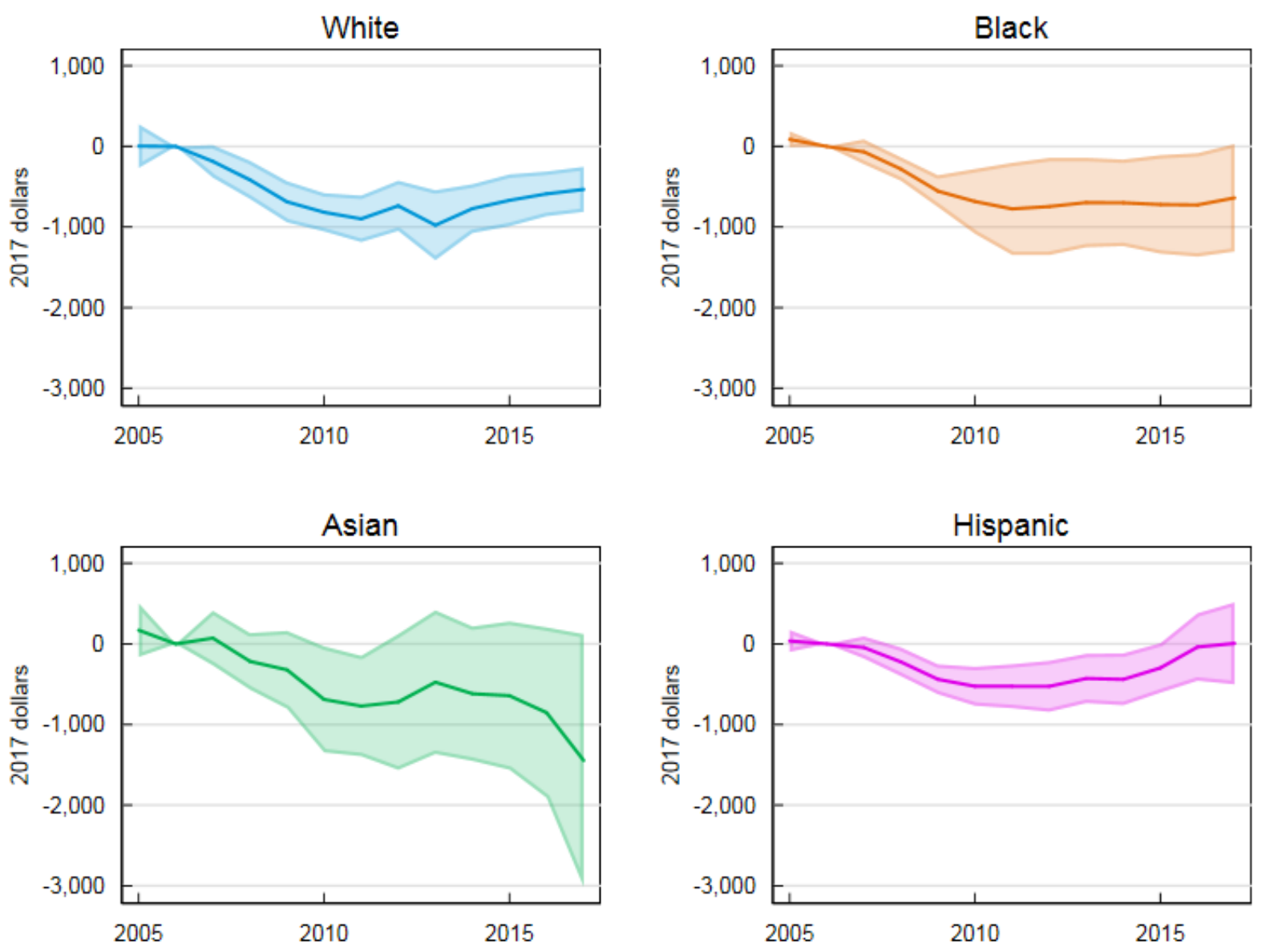

Source: Form 1040, Form 1099, Form W-2, Census Numident, American Community Survey (2001 through 2017), Decennial Census (2000 and 2010), MAF-ARF. Release authorization number CBDRB-FY19-376.

Note: Points plotted are $\beta$ coefficients as estimated in Equation 1. Shaded regions represent 95 percent confidence intervals. 
Figure 14: Person vs. Place Estimates, 1928-1996 Birth Cohorts
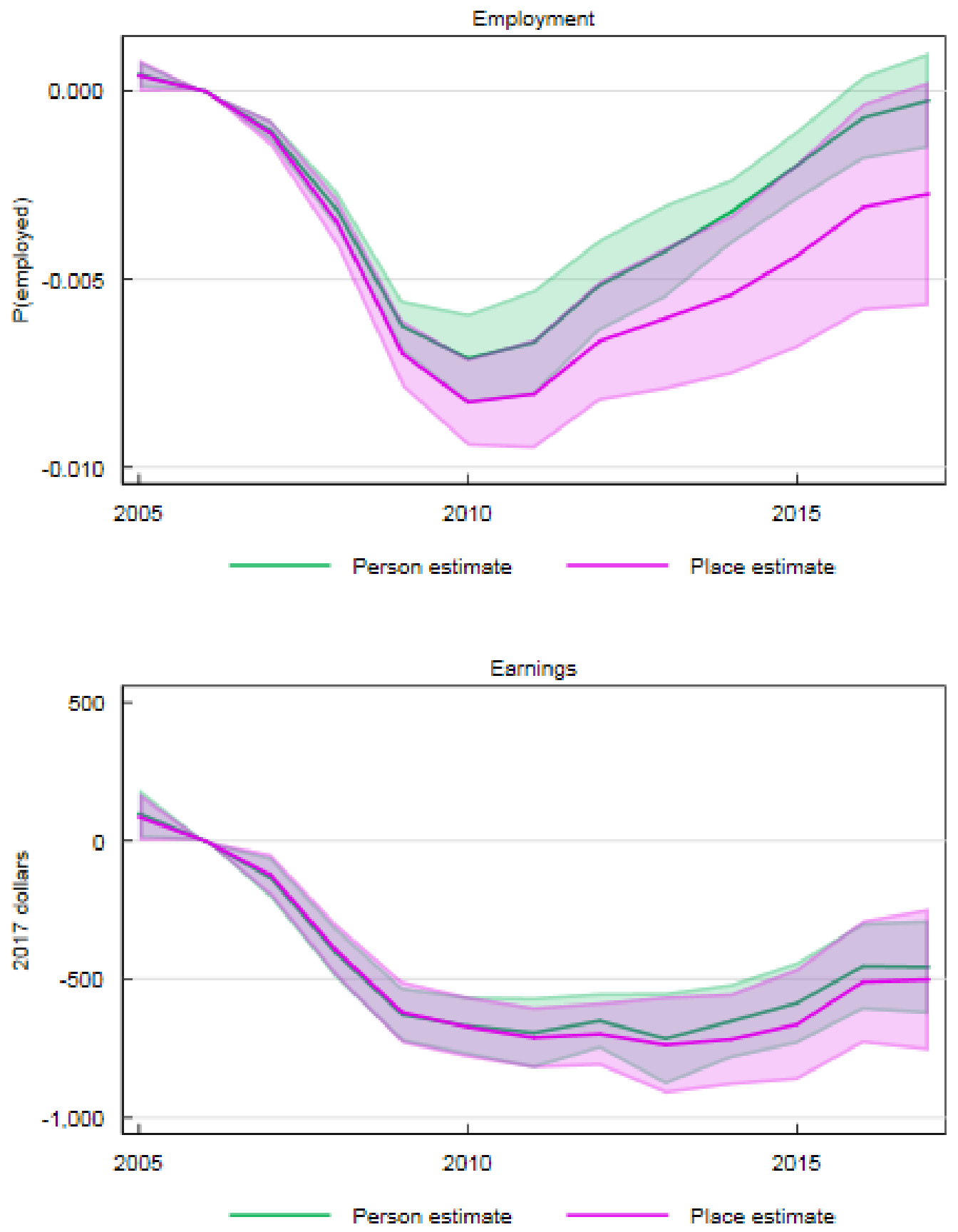

Source: Form 1040, Form 1099, Form W-2, Census Numident, American Community Survey (2001 through 2017), Decennial Census (2000 and 2010), MAF-ARF. Release authorization number CBDRB-FY19-376.

Note: Points plotted in green are $\beta$ coefficients as estimated in Equation 1 Points plotted in magenta are $\beta$ coefficients as estimated in Equation 3 Shaded regions represent 95 percent confidence intervals. 
Figure 15: Effects of Local Concentration Shocks on Employment and Earnings, 1928-1996 Birth Cohorts
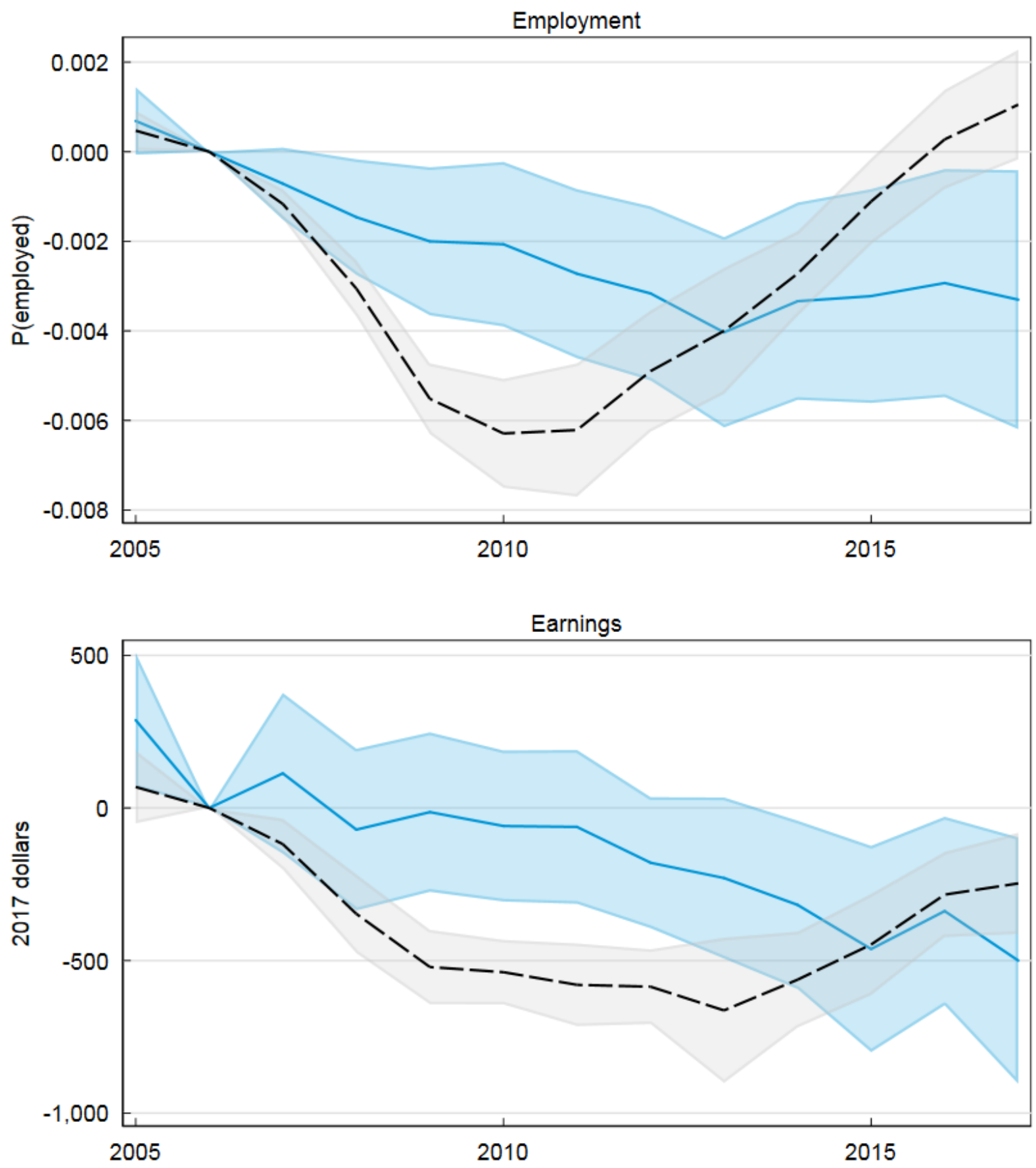

Source: Form 1040, Form 1099, Form W-2, Census Numident, American Community Survey (2001 through 2017), Decennial Census (2000 and 2010), MAF-ARF. Release authorization number CBDRB-FY19-500.

Note: Points plotted in solid, blue lines are $\beta$ coefficients as estimated in Equation 4 . Dashed black lines are the effects of local unemployment shocks from this estimating equation (the $\zeta$ coefficients), for reference. Shaded regions represent 95 percent confidence intervals. 
Figure 16: Effects of Local Concentration Shocks on Employment, by Generation
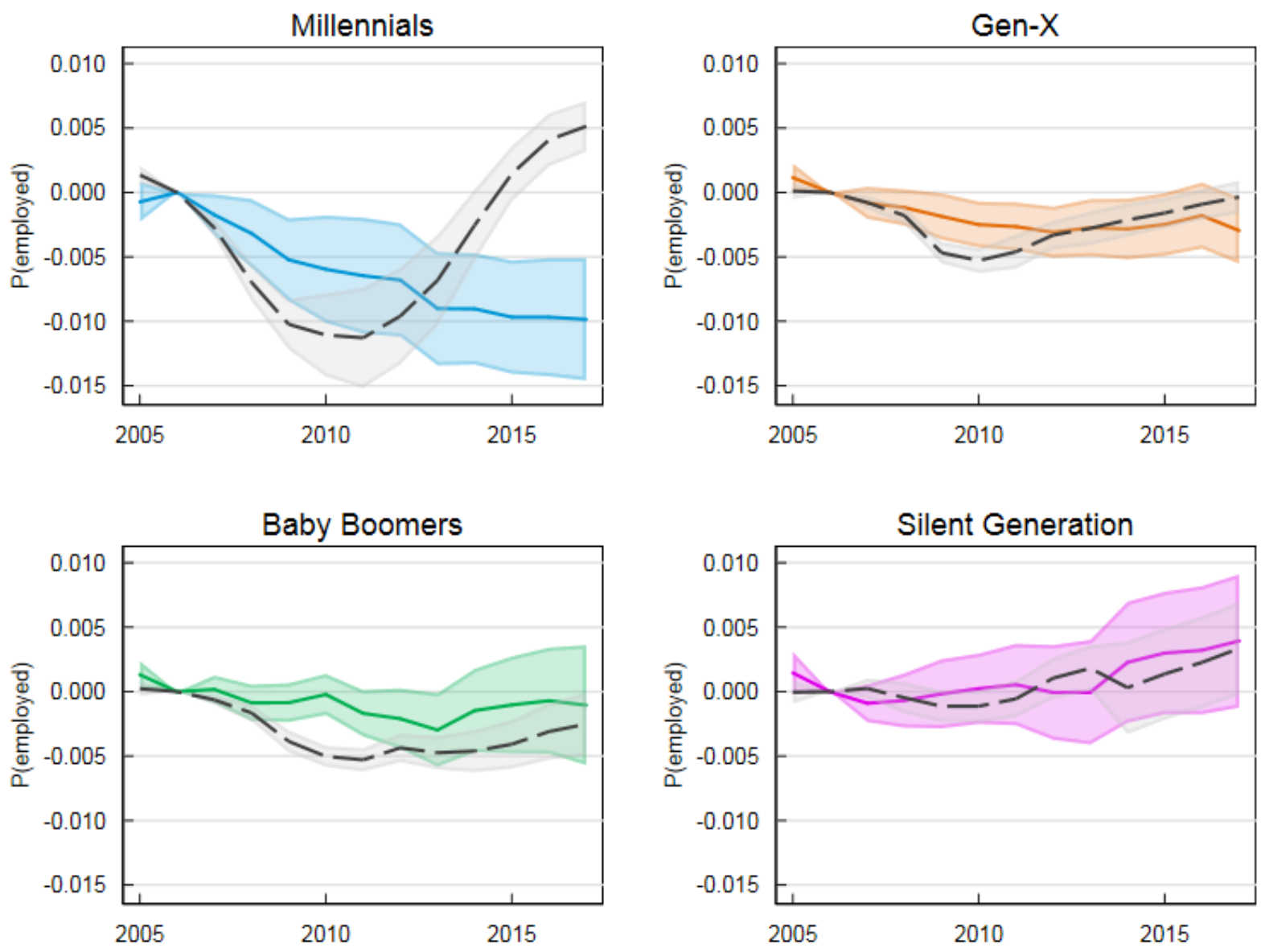

Source: Form 1040, Form 1099, Form W-2, Census Numident, American Community Survey (2001 through 2017), Decennial Census (2000 and 2010), MAF-ARF. Release authorization number CBDRB-FY19-500.

Note: Points plotted in solid, colored lines are $\beta$ coefficients as estimated in Equation 4 . Dashed black lines are the effects of local unemployment shocks from this estimating equation (the $\zeta$ coefficients), for reference. Shaded regions represent 95 percent confidence intervals. 
Figure 17: Effects of Local Concentration Shocks on Earnings, by Generation
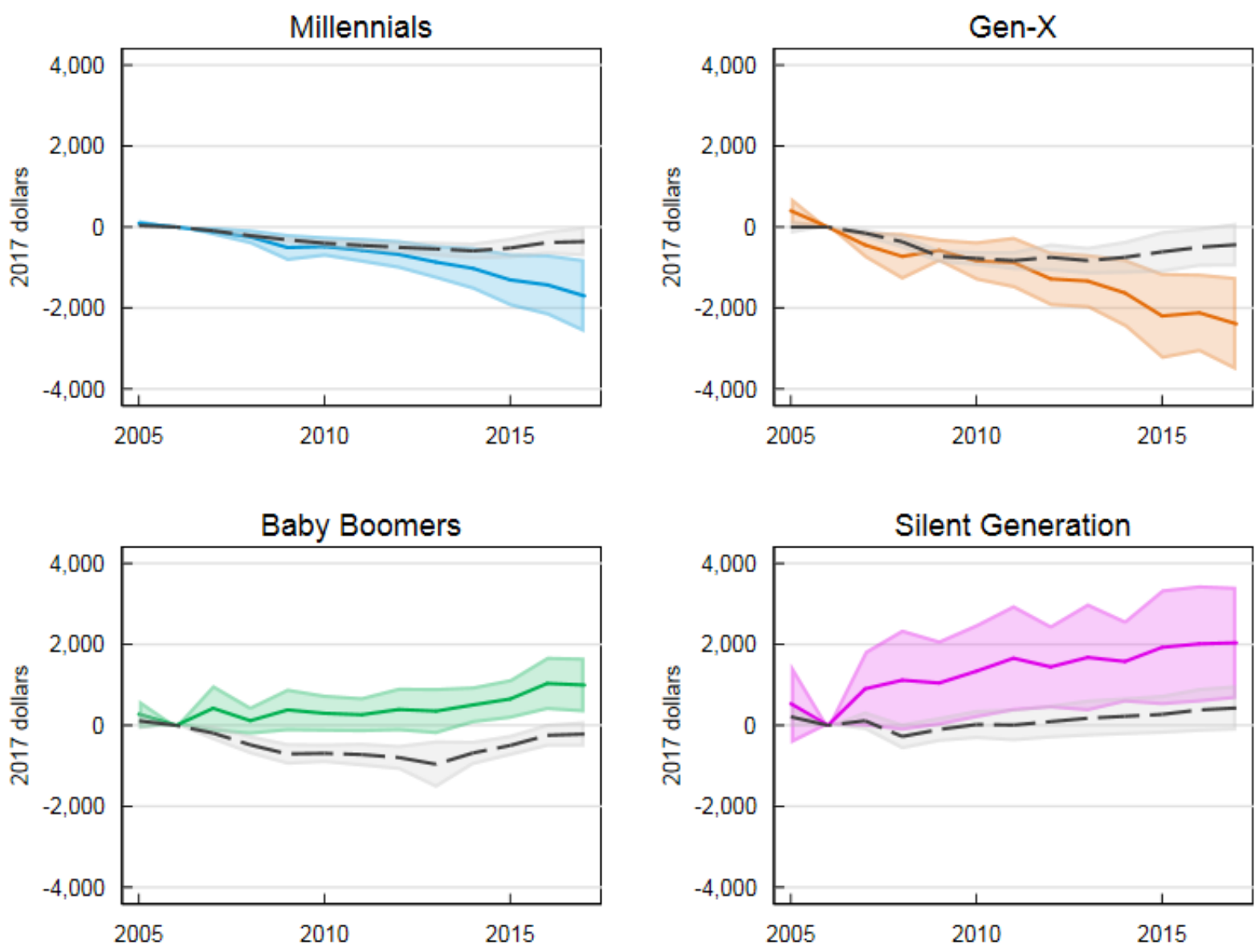

Source: Form 1040, Form 1099, Form W-2, Census Numident, American Community Survey (2001 through 2017), Decennial Census (2000 and 2010), MAF-ARF. Release authorization number CBDRB-FY19-500.

Note: Points plotted in solid, colored lines are $\beta$ coefficients as estimated in Equation 4. Dashed black lines are the effects of local unemployment shocks from this estimating equation (the $\zeta$ coefficients), for reference. Shaded regions represent 95 percent confidence intervals. 


\section{Appendix A Additional Data Details}

\section{A.1 Differences from Yagan (2018)}

As discussed above, Yagan (2018) focuses on prime-age workers born between 1957 and 1976 . I present estimates based on these cohorts in Figure 2. Even in that figure, though, there are three noteworthy differences between the data and methods used here and in that paper.

First, the Yagan analysis is limited to US citizens, and my analysis is not. Second, the methods used to assign individuals to commuting zones differ. Yagan uses ZIP codes listed on tax forms and a ZIP-county crosswalk to place individuals in commuting zones. If location information is not available for an individual in a given year, that person-year observation is assigned to the commuting zone in which the individual was most recently observed in the data. Here, I use location information from a variety of sources to assign individuals to commuting zones. Broadly speaking, these sources include the counties associated with the Master Address File identifiers (MAFIDs) that appear on the Census Bureau's research files in place of exact addresses and ZIP codes from Forms 1040 and 109939 Specifically, I obtain location information from six sources, prioritized as follows:

1. MAFID from Form 1040

2. ZIP code from Form 1040, crosswalked to county

3. MAFID from Form 1099

4. ZIP code from Form 1099, crosswalked to county

5. MAFID from American Community Survey

6. MAFID from Master Address File-Auxiliary Reference File

Individuals may receive multiple 1099s. I use the modal MAFID (if available) and the modal ZIP code (if MAFID is not available). In cases of multiple modes, I select randomly among them. Location information from tax forms is applied to the calendar year that the forms refer to (not the year in which the forms would have been filed). Location information from the American

\footnotetext{
${ }^{39}$ MAFIDs are assigned by comparing address information on a given given file to the Census Bureau's Master Address File. The exact address information is then removed from the version of thefile provided to researchers, and the MAFID, as well as commonly used geographic identifiers associated with it (e.g. state, county, tract), are attached.
} 
Community Survey is available only for survey respondents and is applied to the calendar year in which the response was provided. The Master Address File-Auxiliary Reference File (MAFARF) contains all know MAFIDs associated with each person in each year collected from sources mentioned above as well as data from other federal and state programs.

Finally, the specifications used to produce my estimates are conceptually similar to but technically different from those used in Yagan (2018). Yagan's preferred estimates are based on his equation 4.1:

$$
e_{i t}=\beta S H O C K_{c(i 2007)}+\theta_{g i(2006)}+\epsilon_{i t}
$$

In this specification, the $\theta_{g i(2006)}$ term represents a set of age-earnings-industry fixed effects, measured in 2006. The outcome $e_{i t}$ (whether employment or earnings) is measured relative to its average from 1999 through 2006. For employment, it is defined as

$$
e_{i t} \equiv E M P L O Y E D_{i t}-\frac{1}{8} \sum_{s=1999}^{2006} E M P L O Y E D_{i s}
$$

The corresponding specification in this paper is provided in Equation 1, reproduced here:

$$
y_{i t}=\sum_{t=2005}^{2017} \beta_{t} \text { Shock }_{C Z 07(i)} \cdot 1[\text { Year }=t]+\sum_{a \in a g e s} \alpha_{a} \cdot 1\left[\text { Age }_{i t}=a\right]+\gamma_{i}+\delta_{t}+\varepsilon_{i t}
$$

There are three important distinctions between these specifications. First, because I have access to a limited amount of pre-recession data, I cannot effectively measure my dependent variables relative to a longer-term pre-recession mean. As such, my dependent variables are simply individual $i$ 's value of outcome $y$ at time $t$. Second, the independent variables in Equation A1 are all timeinvariant, so estimates of effects of shock exposure on outcomes for different years are produced by using dependent variable values from different years and estimating separate regressions. Here, I produce estimates for all years in a single regression by interacting the shock with year dummies and including year fixed effects in the regression. Finally, and related to the first two differences, my specification uses individual fixed effects rather than 2006 age-earnings-industry fixed effects. Consequently, my outcomes are implicitly measured relative the individual $i$ 's full period mean. 


\section{A.2 Replicating Yagan (2018) data}

As discussed above, I do not have the capacity to match the preferred specification from Yagan (2018) exactly, but I can produce estimates using my preferred specification (from Equation 1) on data that are constructed as similarly as possible to the data used in that paper. Specifically, this entails using only data on citizens, identifying location using only ZIP codes (and a crosswalk graciously provided by Yagan), and using a different the location imputation strategy. As in Figure 2. analysis is limited to the 1957 through 1976 birth cohorts. As Figure A1 shows, estimates based on this construction of the data are very similar to the estimates in Figure $2^{40}$

\section{A.3 Robustness to Alternative Sample Constructions}

My baseline sample requires that individuals have location information available in all 13 years, allowing gaps of up to three consecutive years to be filled in via imputation if observations on both ends of the gap are in the same commuting zone. This requirement represents a relatively high degree of attachment to formal employment or connection to the administrative state, and estimates based on this sample may not be representative of populations that are more frequently disconnected from the tax filing system. At the same time, this sample construction does not eliminate the potential for location to be mismeasured, and my imputation methodology could bias these estimates if it places individuals in the wrong commuting zones in 2007.

To check the sensitivity of my estimates to the requirements for inclusion in my sample, I reproduce my baseline estimates on two alternative samples: one that relaxes the location information availability requirement, and one that intensifies it. The first, broader sample includes individuals with location information available in at least 7 of the 13 years of data used (one of which must be 2007, in order to be assigned an unemployment shock value). The second, more restrictive sample includes only individuals with non-imputed location information available in all 13 years of data.

Figure A2 shows employment and earnings effects for all cohorts estimated using the broader sample, while Figures A3 and A4 report employment and earnings effects, respectively, by genera-

\footnotetext{
${ }^{40}$ Yagan's employment and earnings measures are based on combined W-2 and certain 1099 income. My data do not provide income amounts from 1099s, so my measures are based only on W-2 income. I do have an indicator for receipt of various 1099s, so I can construct a comparable employment measure for the sake of this exercise, but in all other cases, employment is based only on receipt of $\mathrm{W}-2$ income, for the sake of consistency with the earnings estimates.
} 
tion. Likewise, Figures A5, A6, and A7 present estimates for the narrower sample. All estimates are very similar to the baseline estimates presented in the main text of the paper. Estimates from the broader sample are especially similar to the baseline, alleviating to some extent concerns that the baseline estimates may not reflect the experience of workers who have less consistent interactions with the formal labor market or tax filing system. 


\section{A.4 Figures}

Figure A1: Effects of Local Unemployment Shocks on Employment and Earnings, 1957-1976 Birth Cohorts, Data Constructed as in Yagan $(2018)$
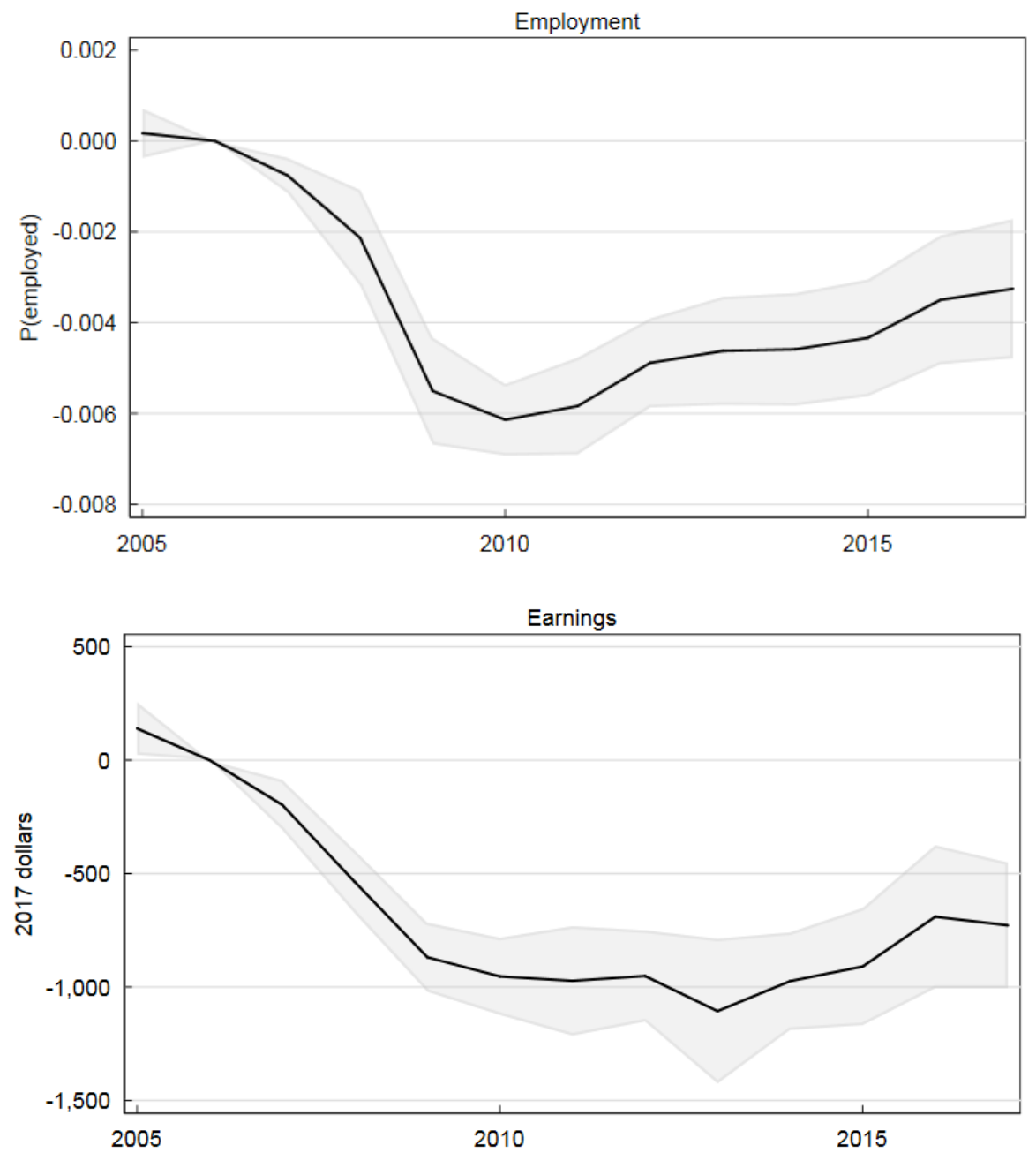

Source: Form 1040, Form 1099, Form W-2, Census Numident, American Community Survey (2001 through 2017), Decennial Census (2000 and 2010), MAF-ARF. Release authorization number CBDRB-FY19-376.

Note: Points plotted are $\beta$ coefficients as estimated in Equation 1 Shaded regions represent 95 percent confidence intervals. 
Figure A2: Effects of Local Unemployment Shocks on Employment and Earnings, 1928-1996 Birth Cohorts, Allowing Some Missing Data
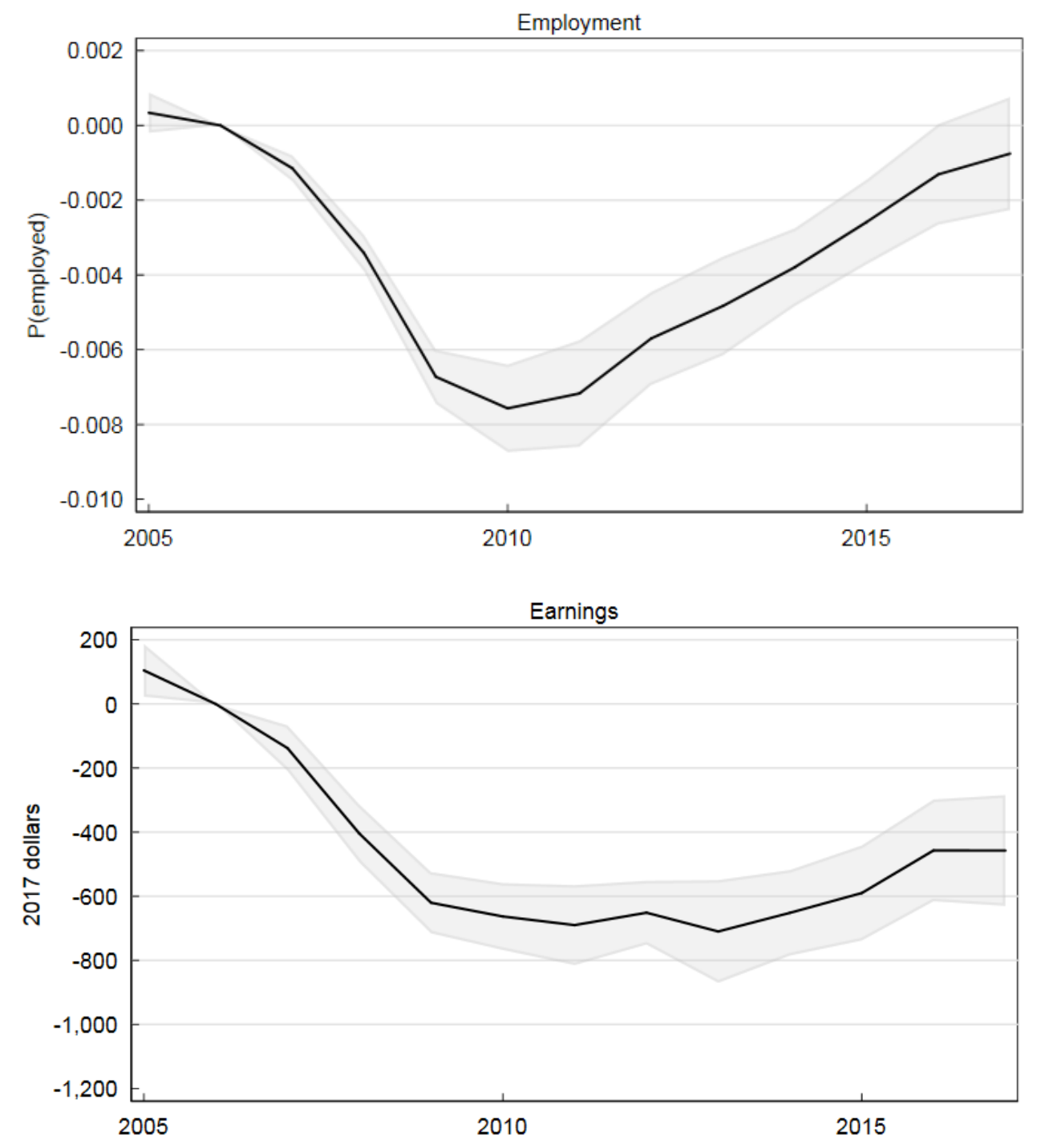

Source: Form 1040, Form 1099, Form W-2, Census Numident, American Community Survey (2001 through 2017), Decennial Census (2000 and 2010), MAF-ARF. Release authorization number CBDRB-FY19-376.

Note: Points plotted are $\beta$ coefficients as estimated in Equation 1 Shaded regions represent 95 percent confidence intervals. 
Figure A3: Effects of Local Unemployment Shocks on Employment, by Generation, Allowing Some Missing Data
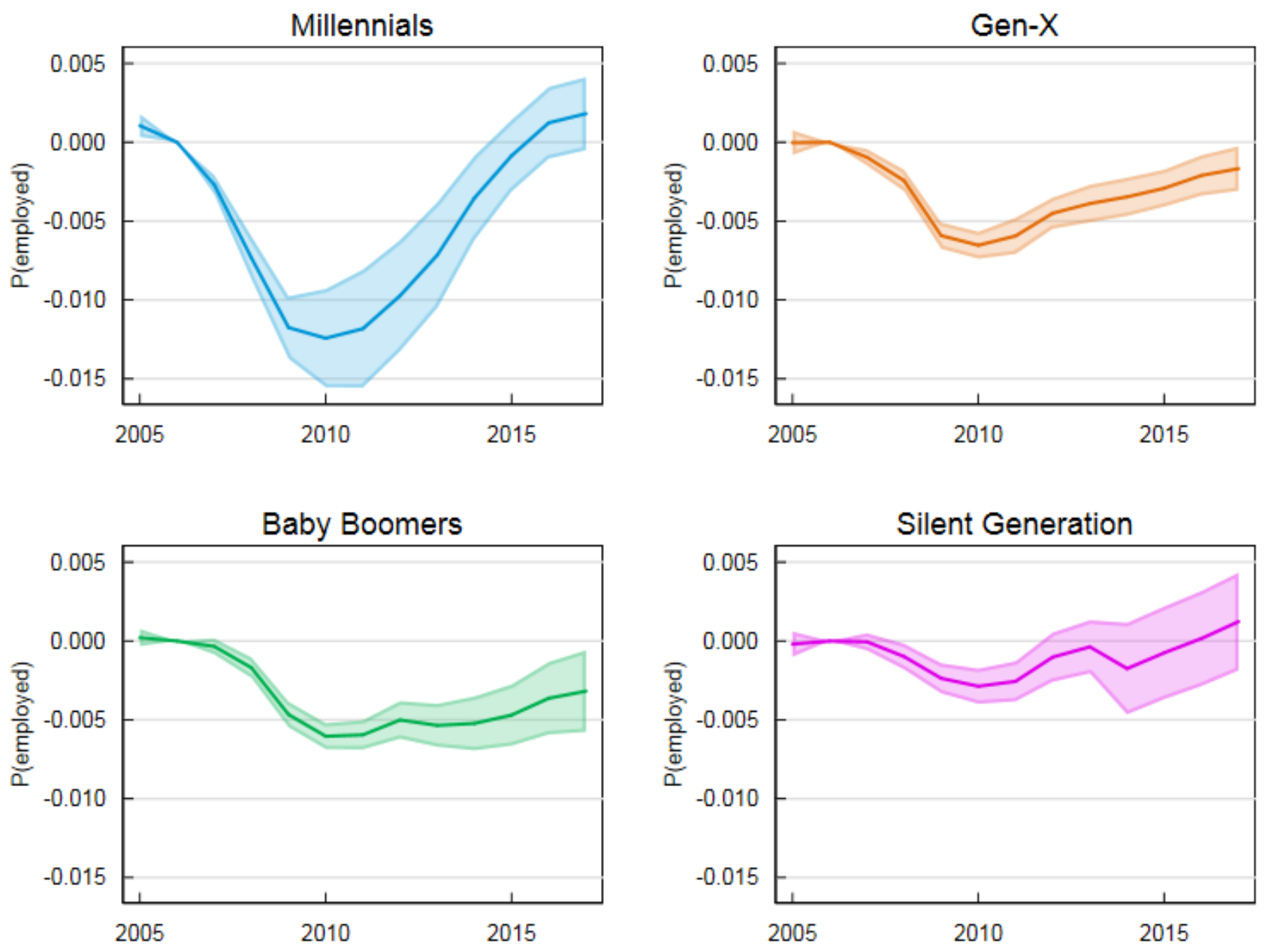

Source: Form 1040, Form 1099, Form W-2, Census Numident, American Community Survey (2001 through 2017), Decennial Census (2000 and 2010), MAF-ARF. Release authorization number CBDRB-FY19-376.

Note: Points plotted are $\beta$ coefficients as estimated in Equation 1. Shaded regions represent 95 percent confidence intervals. 
Figure A4: Effects of Local Unemployment Shocks on Earnings, by Generation, Allowing Some Missing Data
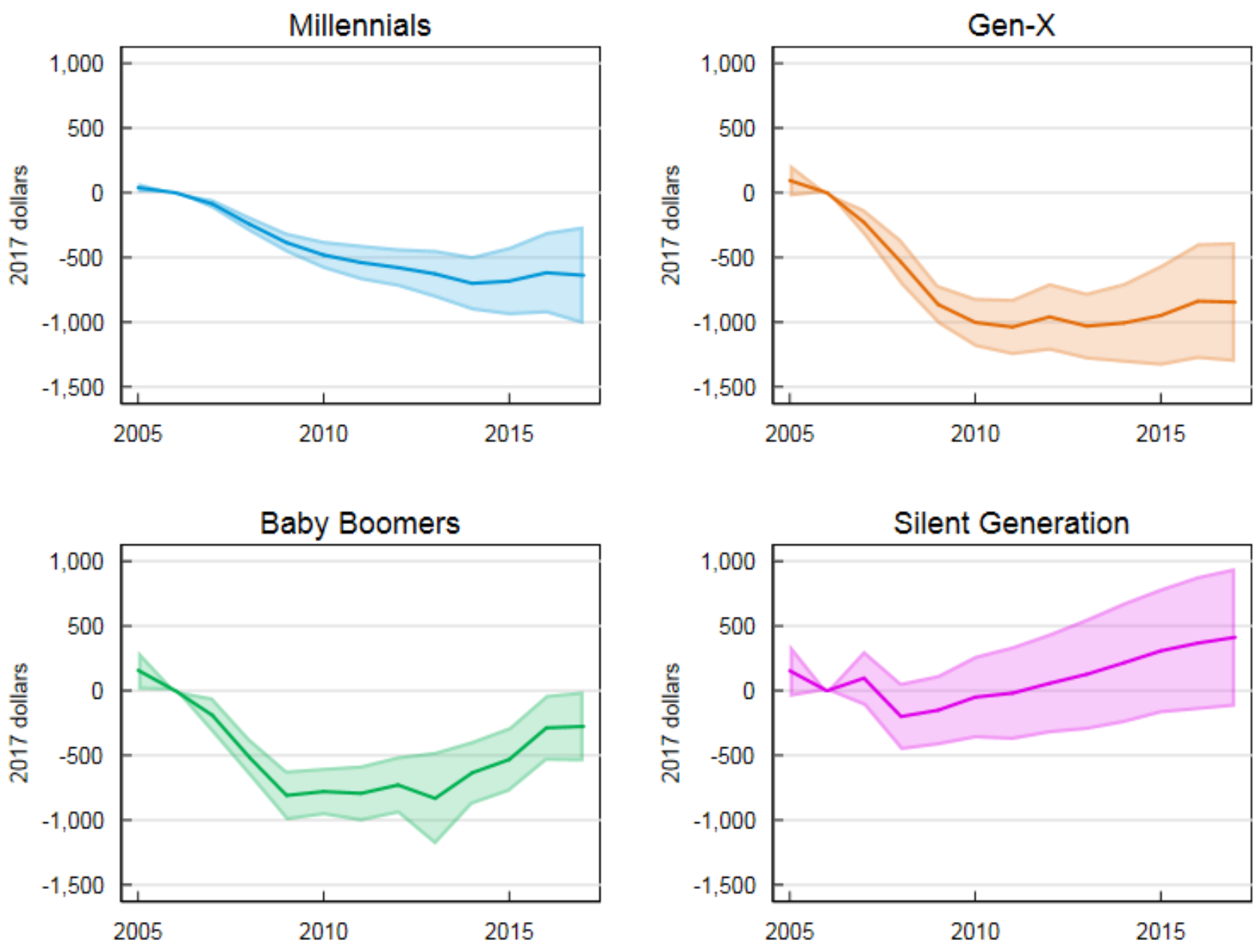

Source: Form 1040, Form 1099, Form W-2, Census Numident, American Community Survey (2001 through 2017), Decennial Census (2000 and 2010), MAF-ARF. Release authorization number CBDRB-FY19-376.

Note: Points plotted are $\beta$ coefficients as estimated in Equation 1. Shaded regions represent 95 percent confidence intervals. 
Figure A5: Effects of Local Unemployment Shocks on Employment and Earnings, 1928-1996 Birth Cohorts, Allowing No Missing Data or Imputation
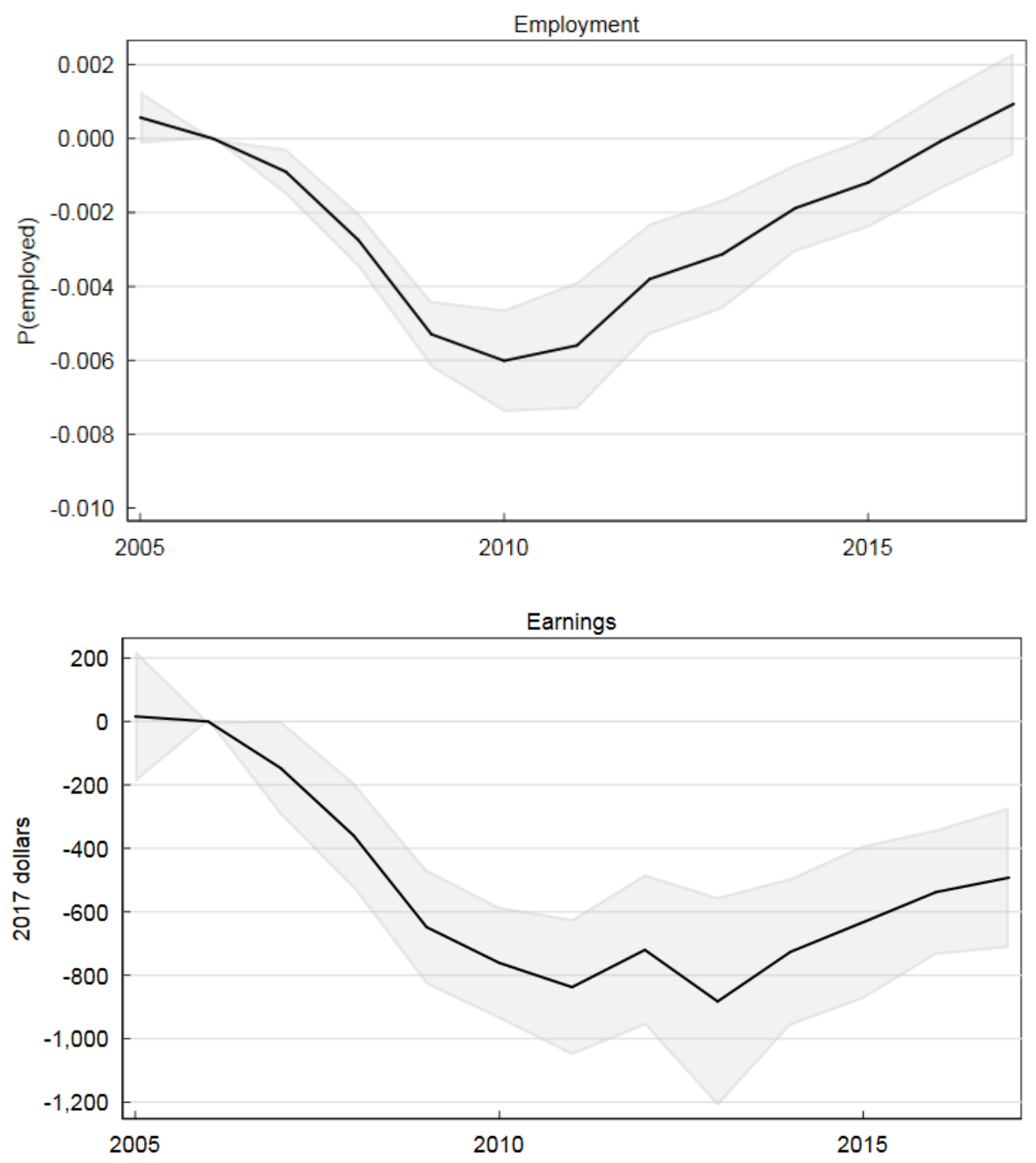

Source: Form 1040, Form 1099, Form W-2, Census Numident, American Community Survey (2001 through 2017), Decennial Census (2000 and 2010), MAF-ARF. Release authorization number CBDRB-FY19-376.

Note: Points plotted are $\beta$ coefficients as estimated in Equation 1 Shaded regions represent 95 percent confidence intervals. 
Figure A6: Effects of Local Unemployment Shocks on Employment, by Generation, Allowing No Missing Data or Imputation
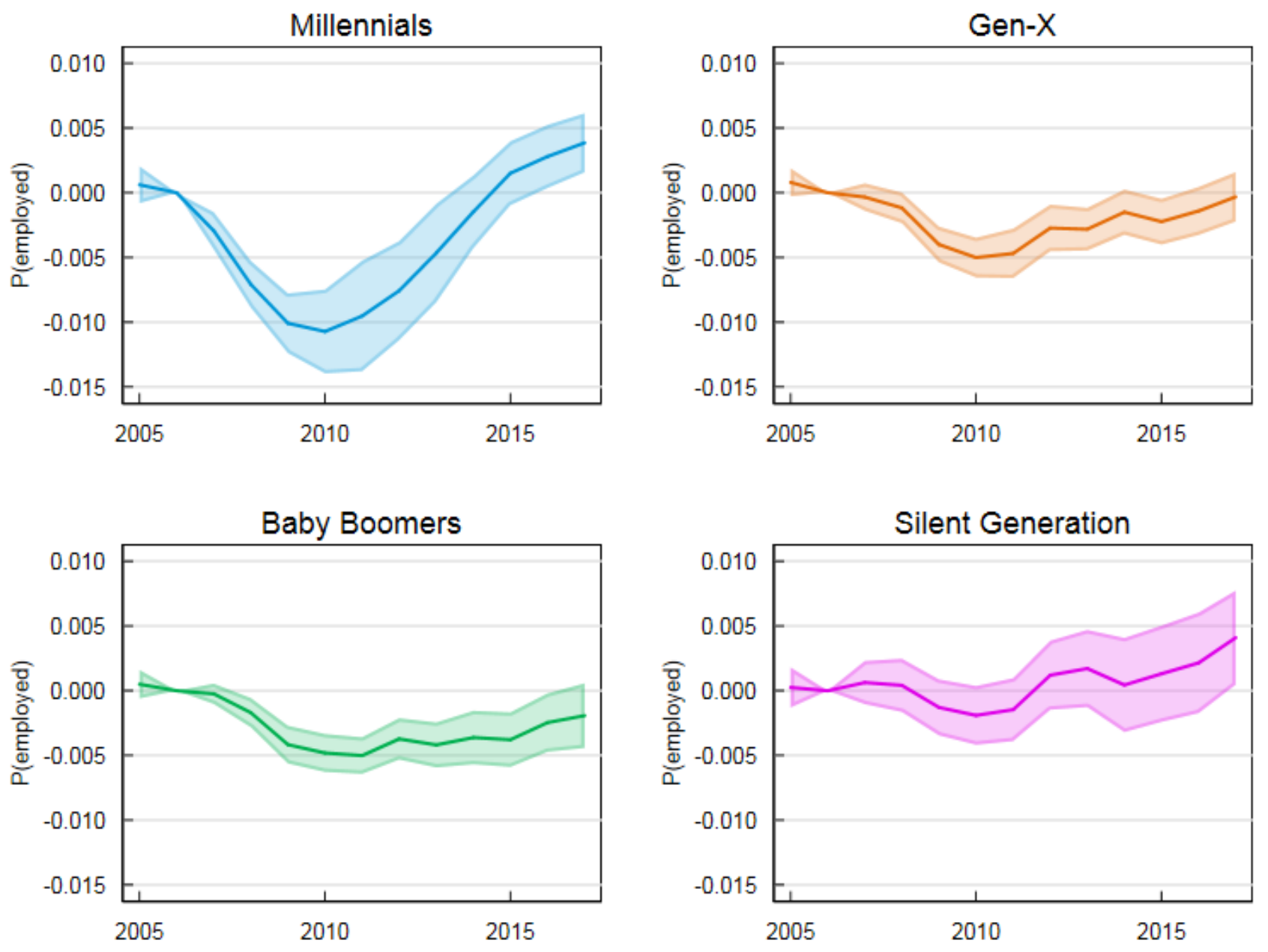

Source: Form 1040, Form 1099, Form W-2, Census Numident, American Community Survey (2001 through 2017), Decennial Census (2000 and 2010), MAF-ARF. Release authorization number CBDRB-FY19-376.

Note: Points plotted are $\beta$ coefficients as estimated in Equation 1. Shaded regions represent 95 percent confidence intervals. 
Figure A7: Effects of Local Unemployment Shocks on Earnings, by Generation, Allowing No Missing Data or Imputation
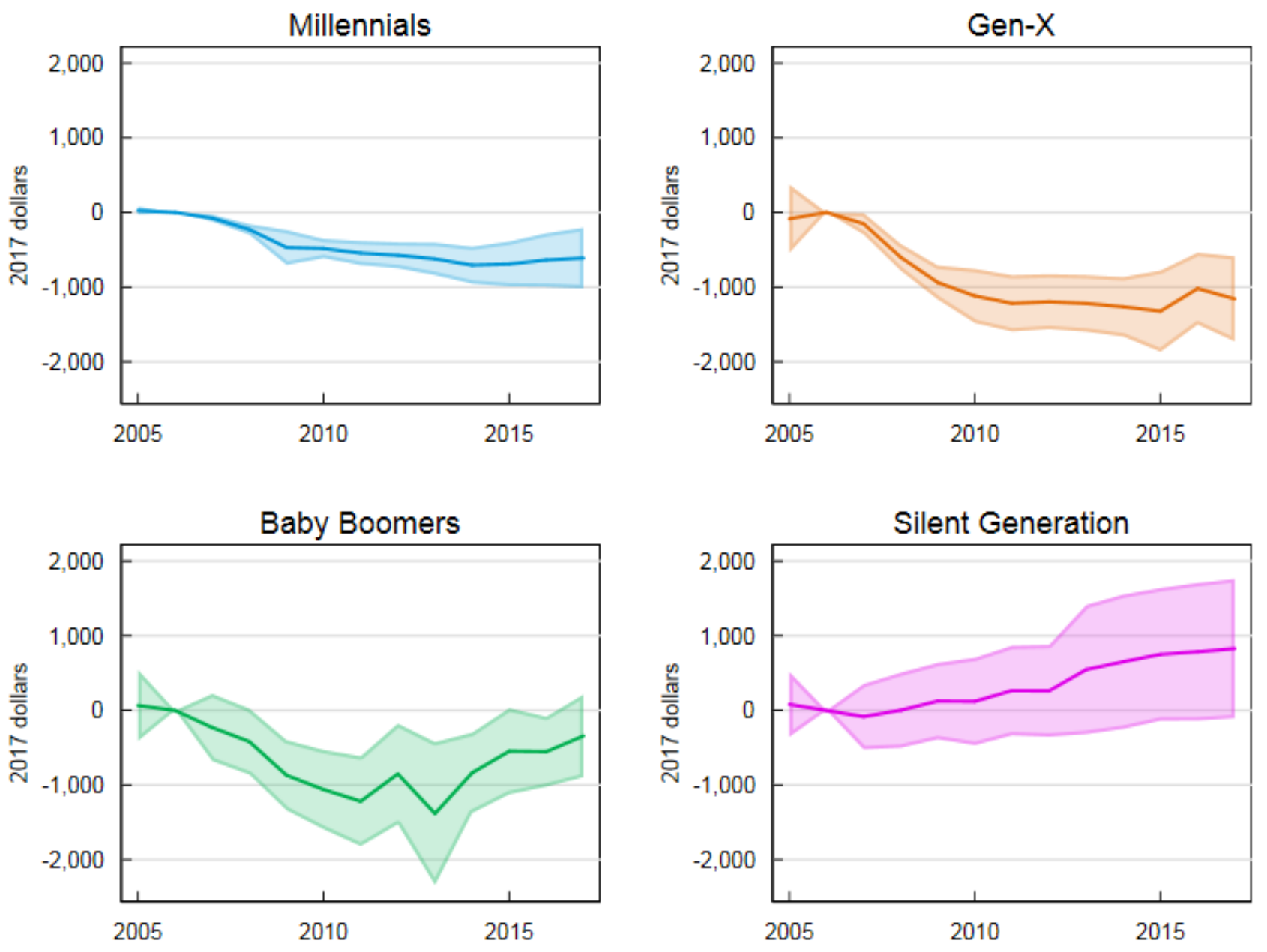

Source: Form 1040, Form 1099, Form W-2, Census Numident, American Community Survey (2001 through 2017), Decennial Census (2000 and 2010), MAF-ARF. Release authorization number CBDRB-FY19-376.

Note: Points plotted are $\beta$ coefficients as estimated in Equation 1. Shaded regions represent 95 percent confidence intervals. 


\section{Appendix B Additional Estimates}

\section{B.1 Estimates as Shares of Outcome Means}

Figure B1: Effects of Local Unemployment Shocks on Employment and Earnings, Coefficients as Shares of Outcome Means
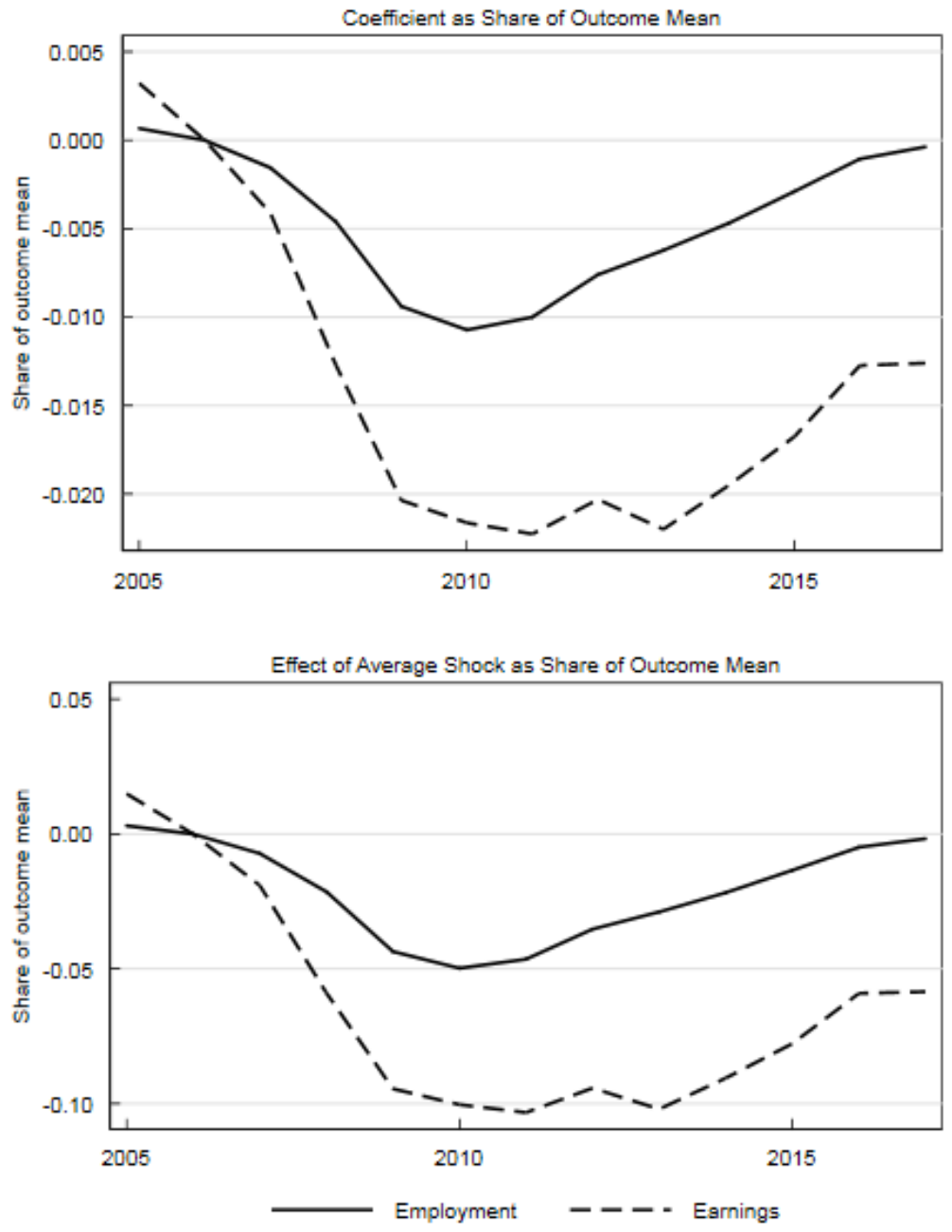

Source: Form 1040, Form 1099, Form W-2, Census Numident, American Community Survey (2001 through 2017), Decennial Census (2000 and 2010), MAF-ARF. Release authorization number CBDRB-FY19-376.

Note: Points plotted are $\beta$ coefficients as estimated in Equation 1 divided by the mean of the corresponding outcome for the relevant group and year. 
Figure B2: Effects of Local Unemployment Shocks on Employment and Earnings, Coefficients as Shares of Mean Outcomes, by Generation
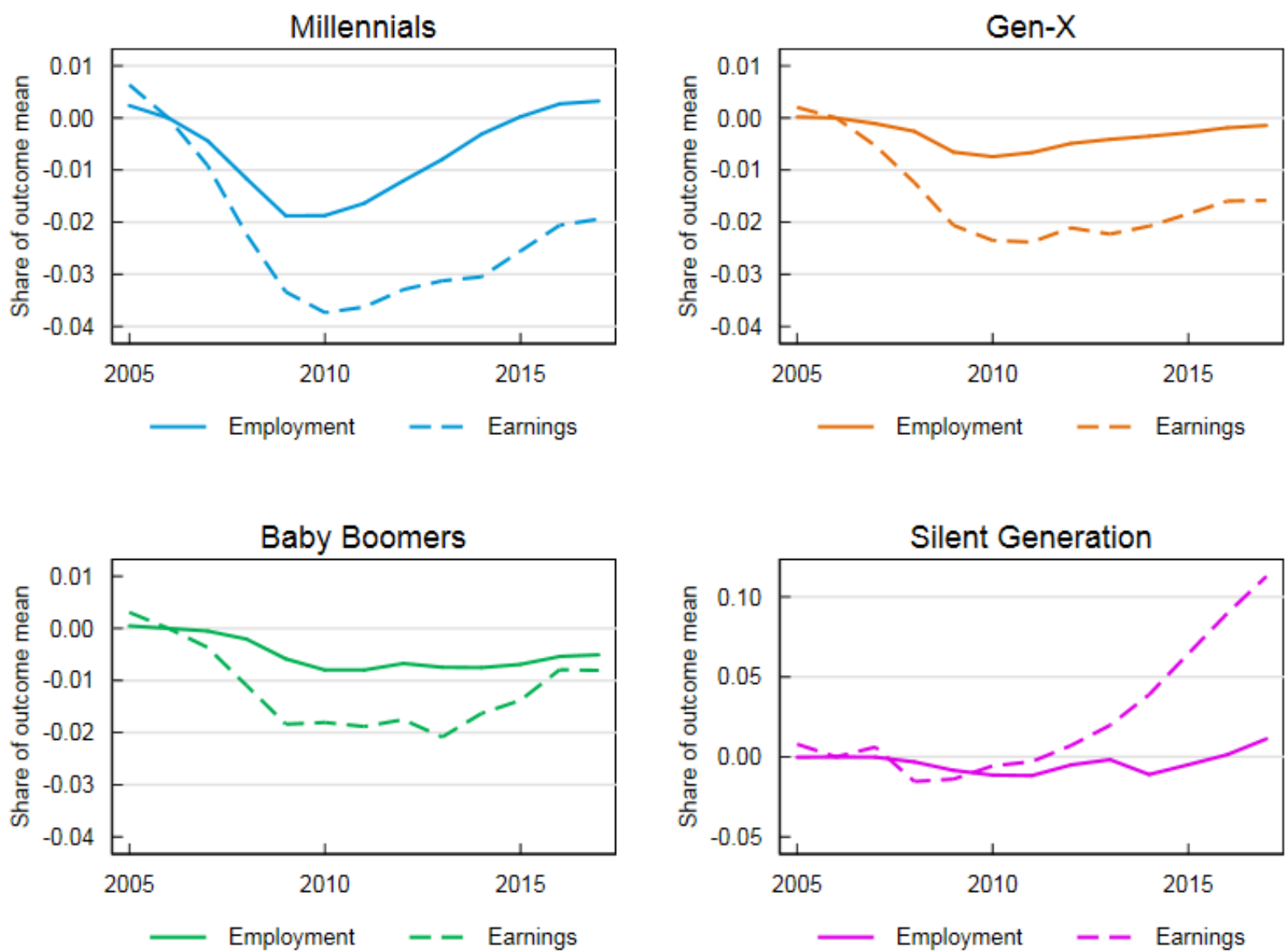

Source: Form 1040, Form 1099, Form W-2, Census Numident, American Community Survey (2001 through 2017), Decennial Census (2000 and 2010), MAF-ARF. Release authorization number CBDRB-FY19-376.

Note: Points plotted are $\beta$ coefficients as estimated in Equation 1, divided by the mean of the corresponding outcome for the relevant group and year. 
Figure B3: Effects of Local Unemployment Shocks on Employment and Earnings, Effects of Average Shocks as Shares of Mean Outcomes, by Generation
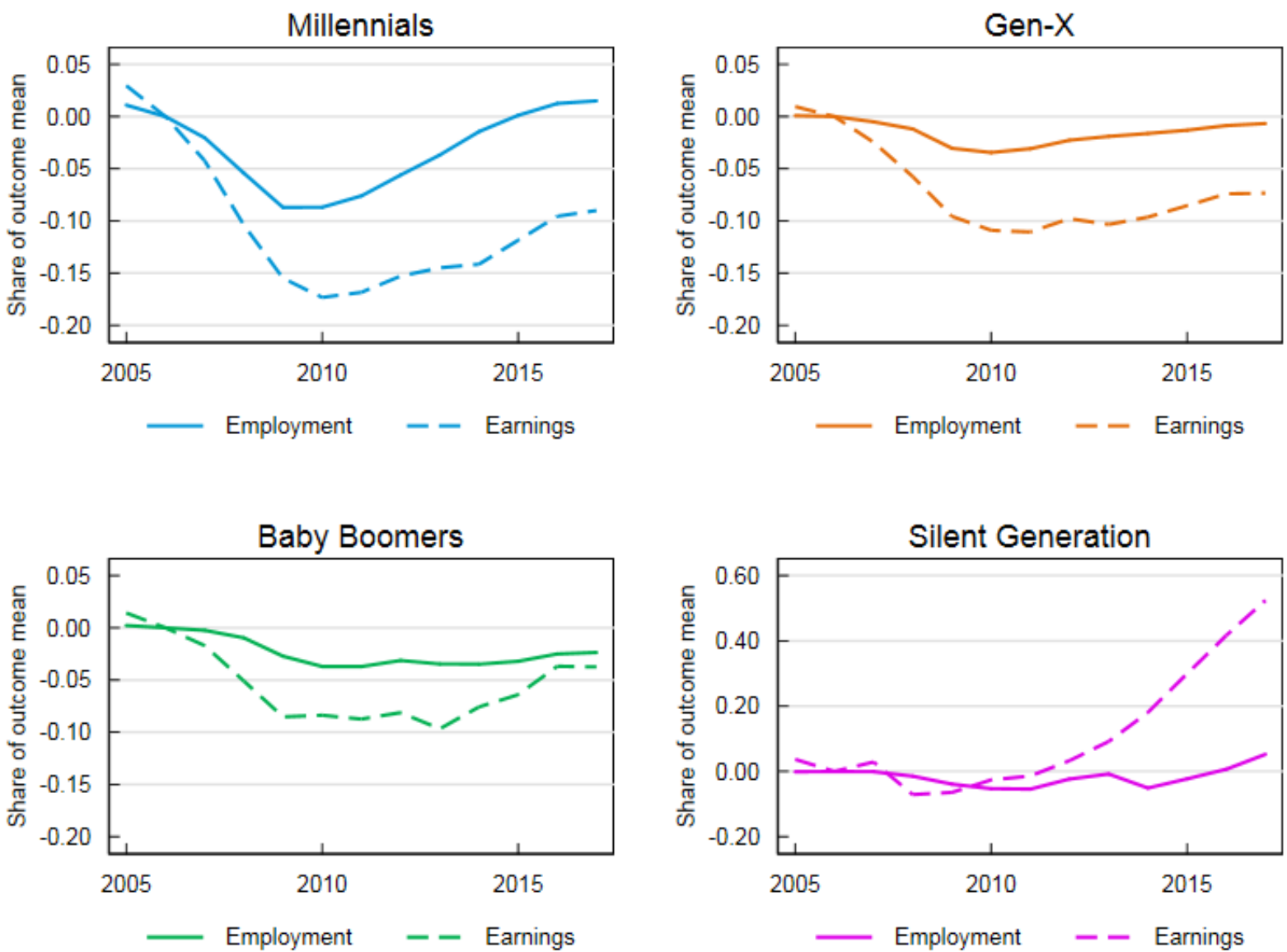

Source: Form 1040, Form 1099, Form W-2, Census Numident, American Community Survey (2001 through 2017), Decennial Census (2000 and 2010 ), MAF-ARF. Release authorization number CBDRB-FY19-376.

Note: Points plotted are $\beta$ coefficients as estimated in Equation 1, multiplied by the magnitude of the average local unemployment shock and then divided by the mean of the corresponding outcome for the relevant group and year. 
Figure B4: Effects of Local Unemployment Shocks on Earnings, by Displacement Status
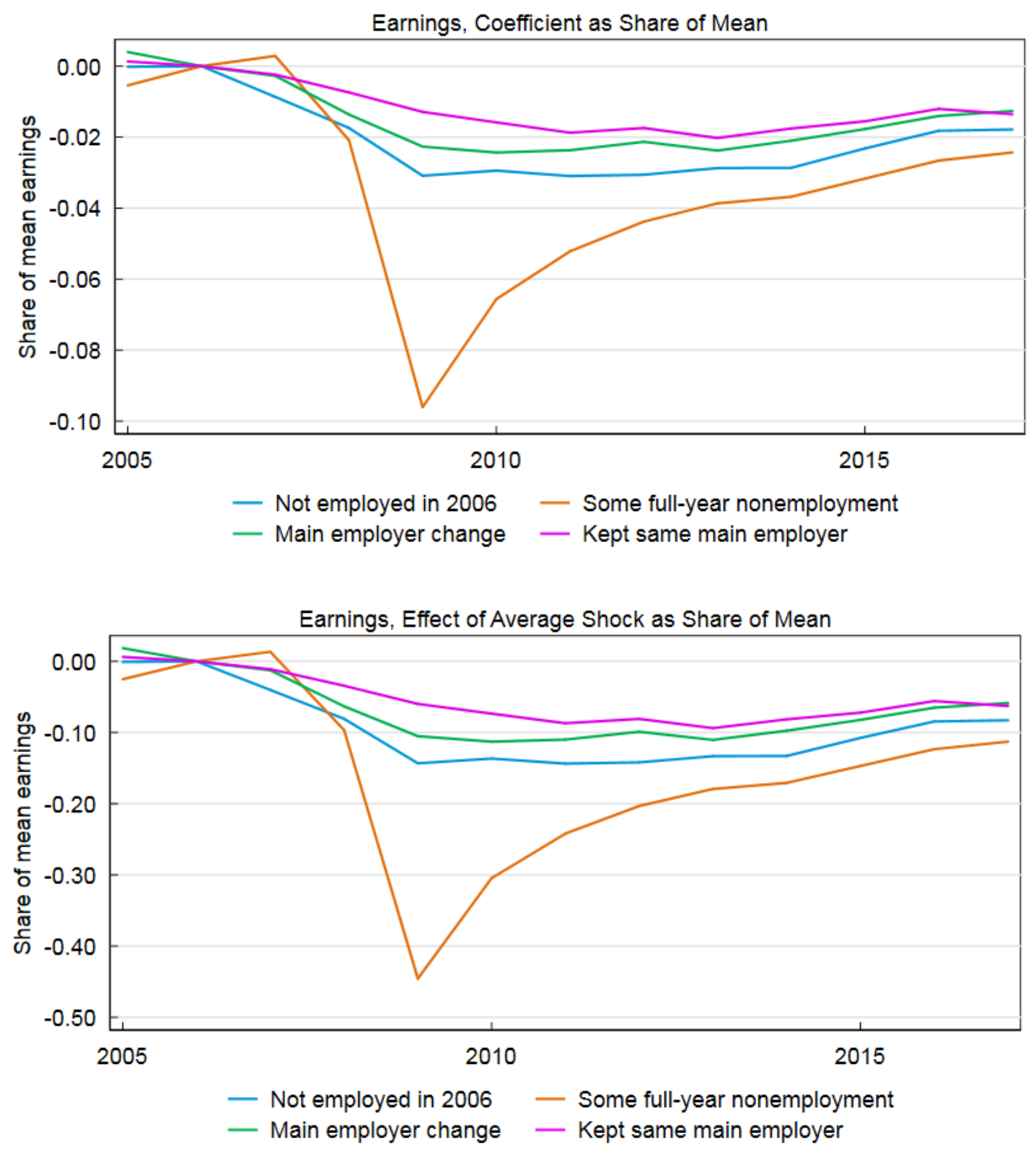

Source: Form 1040, Form 1099, Form W-2, Census Numident, American Community Survey (2001 through 2017), Decennial Census (2000 and 2010), MAF-ARF. Release authorization number CBDRB-FY19-431.

Note: Points plotted are $\beta$ coefficients as estimated in Equation 1 divided by the mean of the corresponding outcome for the relevant group and year. 
Figure B5: Effects of Local Unemployment Shocks on Employment, Coefficients as Shares of Mean Employment, by Gender and Generation
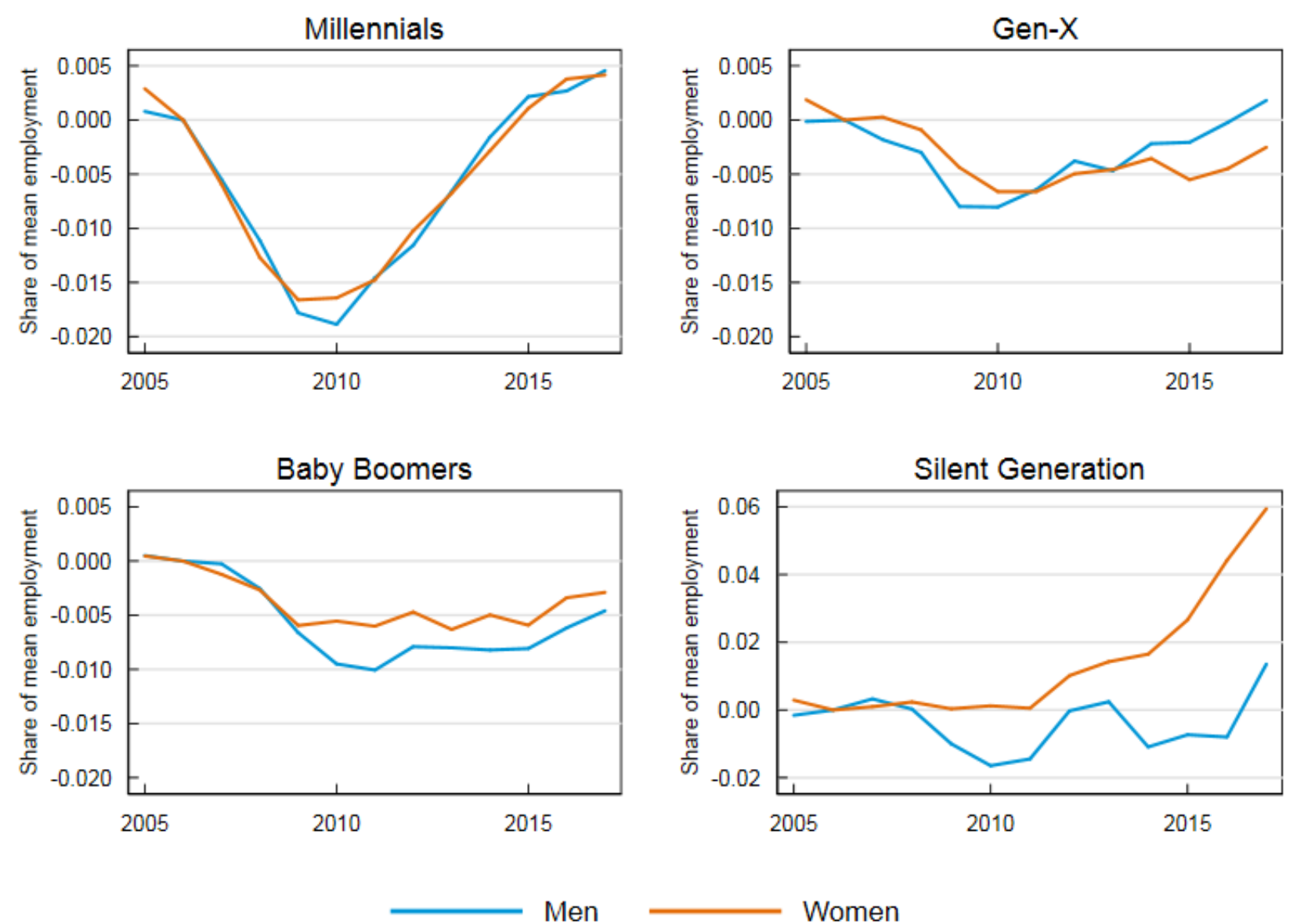

Source: Form 1040, Form 1099, Form W-2, Census Numident, American Community Survey (2001 through 2017), Decennial Census (2000 and 2010), MAF-ARF. Release authorization number CBDRB-FY19-376.

Note: Points plotted are $\beta$ coefficients as estimated in Equation 1, divided by the mean of the corresponding outcome for the relevant group and year. 
Figure B6: Effects of Local Unemployment Shocks on Employment, Effects of Average Shocks as Shares of Mean Employment, by Gender and Generation
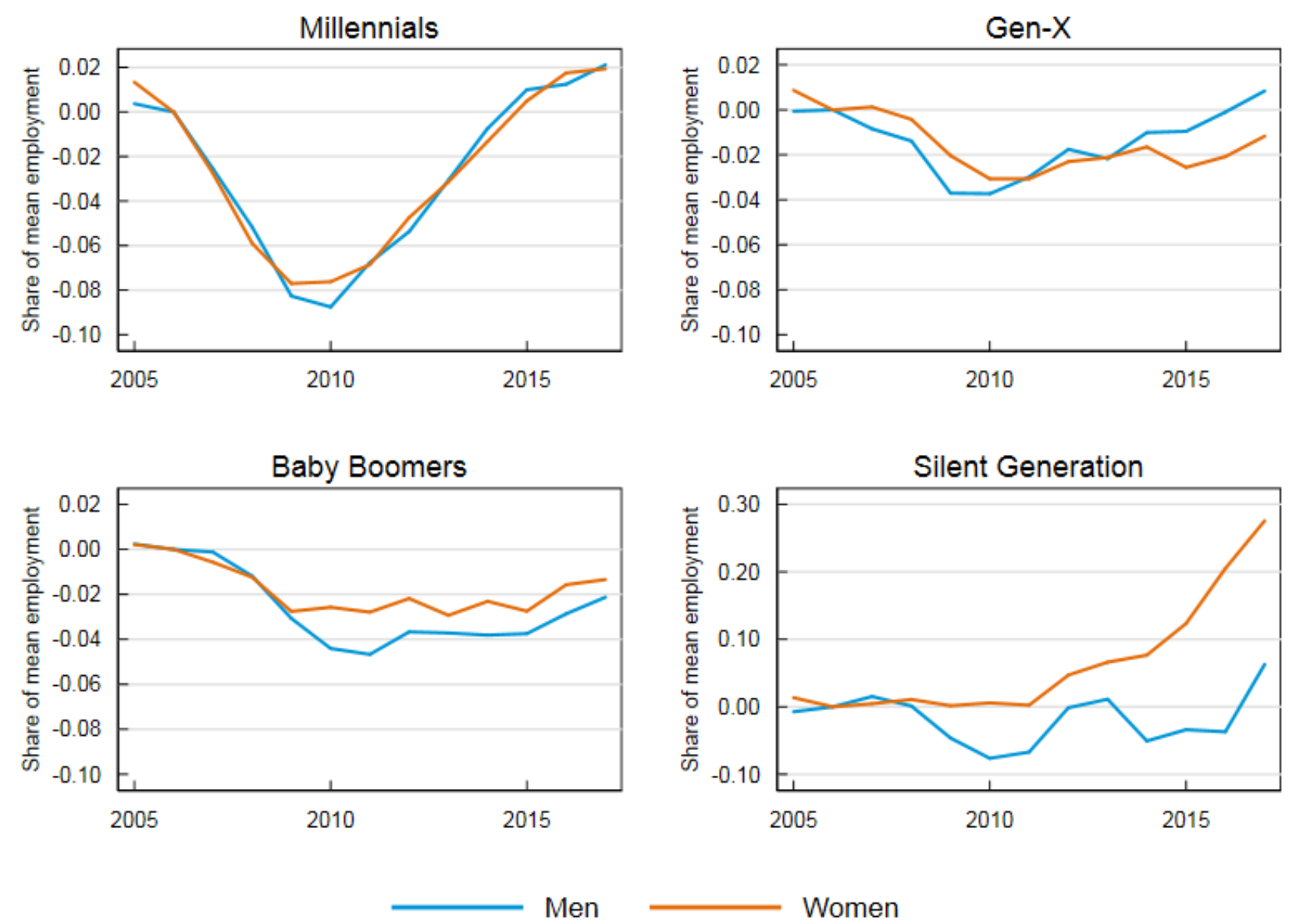

Source: Form 1040, Form 1099, Form W-2, Census Numident, American Community Survey (2001 through 2017), Decennial Census (2000 and 2010 ), MAF-ARF. Release authorization number CBDRB-FY19-376.

Note: Points plotted are $\beta$ coefficients as estimated in Equation 1 , multiplied by the magnitude of the average local unemployment shock and then divided by the mean of the corresponding outcome for the relevant group and year. 
Figure B7: Effects of Local Unemployment Shocks on Earnings, Coefficients as Shares of Mean Earnings, by Gender and Generation
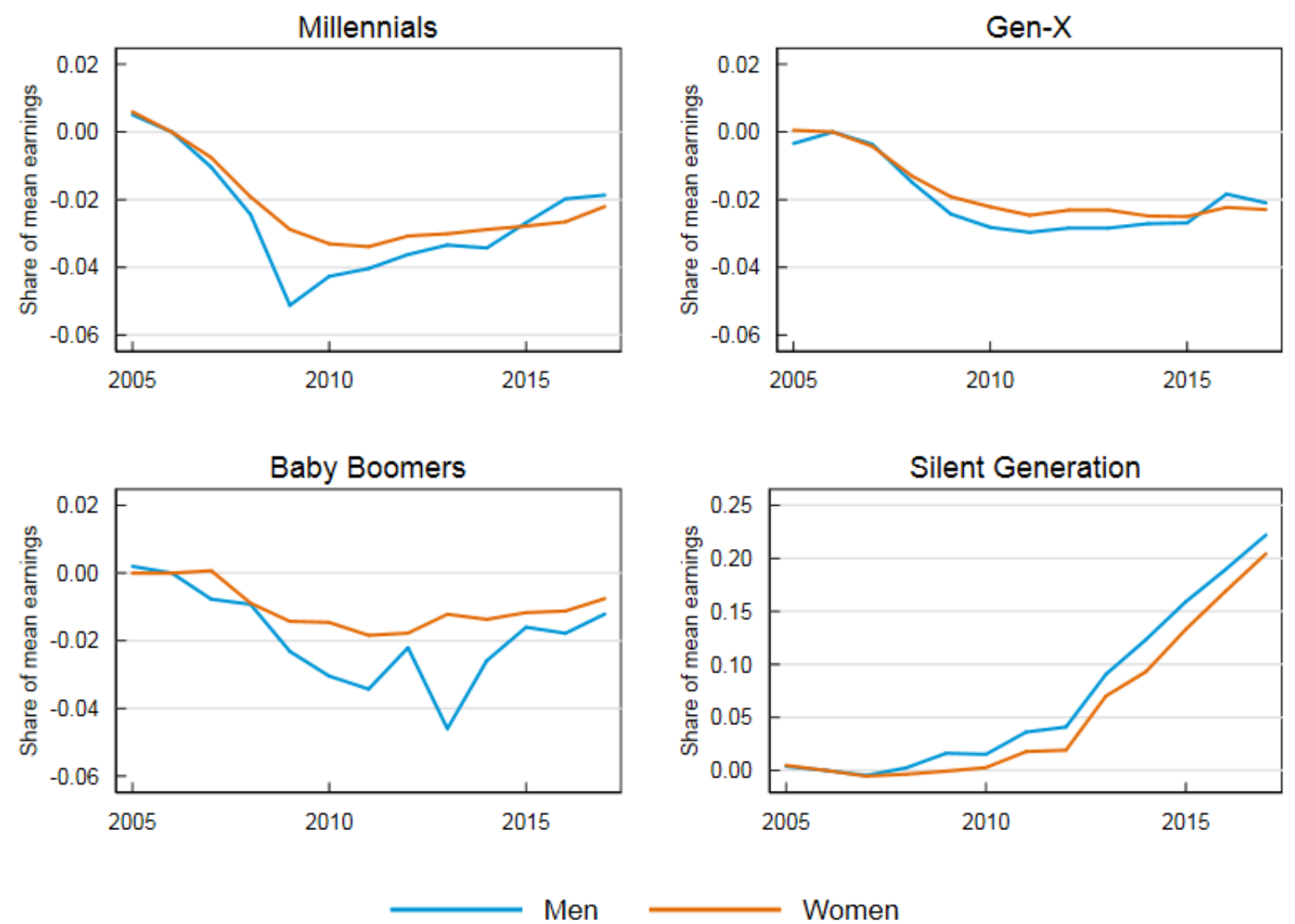

Source: Form 1040, Form 1099, Form W-2, Census Numident, American Community Survey (2001 through 2017), Decennial Census (2000 and 2010), MAF-ARF. Release authorization number CBDRB-FY19-376.

Note: Points plotted are $\beta$ coefficients as estimated in Equation 1, divided by the mean of the corresponding outcome for the relevant group and year. 
Figure B8: Effects of Local Unemployment Shocks on Earnings, Effects of Average Shock as Shares of Mean Earnings, by Gender and Generation
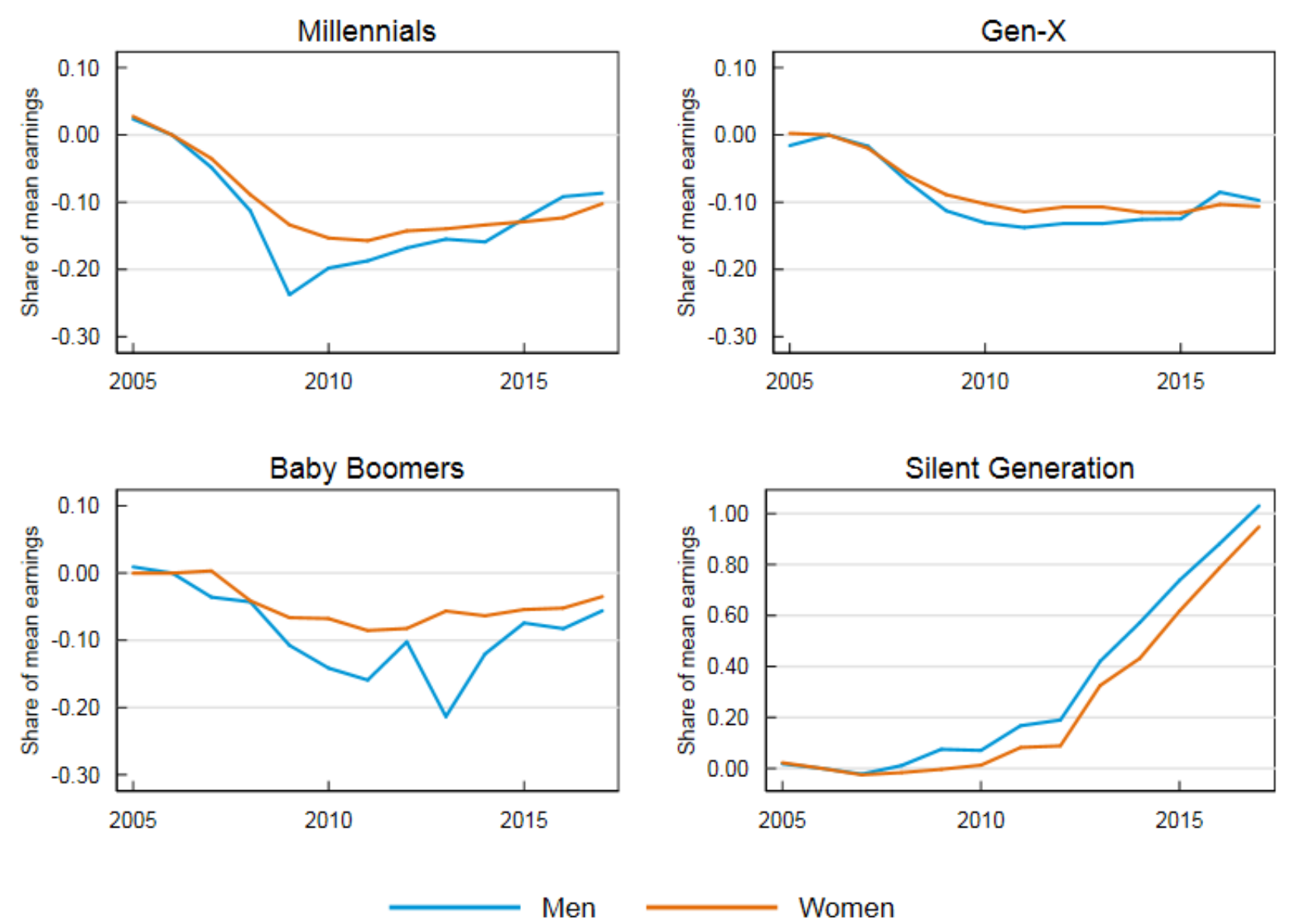

Source: Form 1040, Form 1099, Form W-2, Census Numident, American Community Survey (2001 through 2017), Decennial Census (2000 and 2010 ), MAF-ARF. Release authorization number CBDRB-FY19-376.

Note: Points plotted are $\beta$ coefficients as estimated in Equation 1, multiplied by the magnitude of the average local unemployment shock and then divided by the mean of the corresponding outcome for the relevant group and year. 
Figure B9: Effects of Local Unemployment Shocks on Earnings, Coefficients as Share of Mean Earnings, by Race
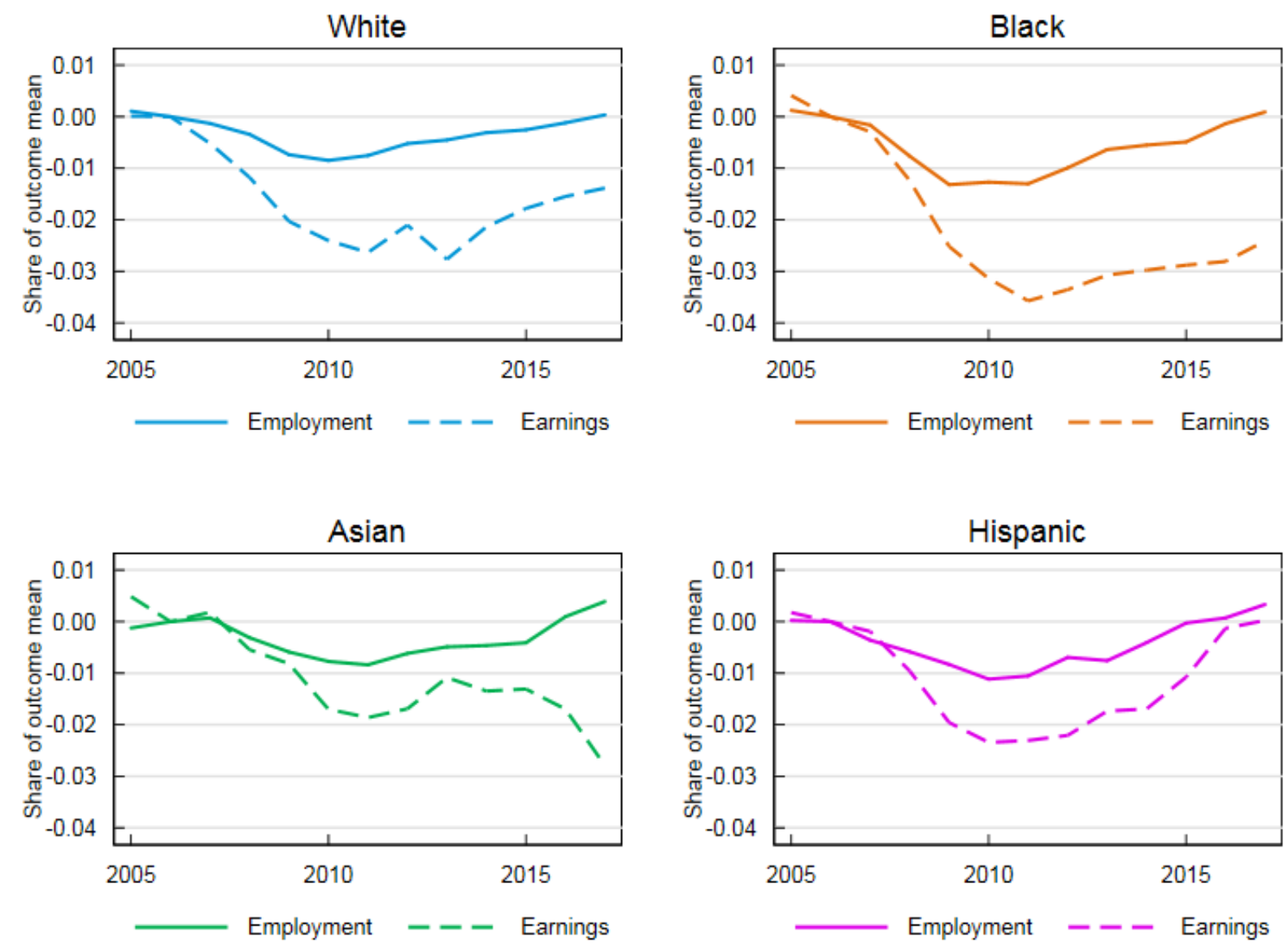

Source: Form 1040, Form 1099, Form W-2, Census Numident, American Community Survey (2001 through 2017), Decennial Census (2000 and 2010 ), MAF-ARF. Release authorization number CBDRB-FY19-431.

Note: Points plotted are $\beta$ coefficients as estimated in Equation 1, divided by the mean of the corresponding outcome for the relevant group and year. 
Figure B10: Effects of Local Unemployment Shocks on Earnings, Effects of Average Shock as Share of Mean Earnings, by Race
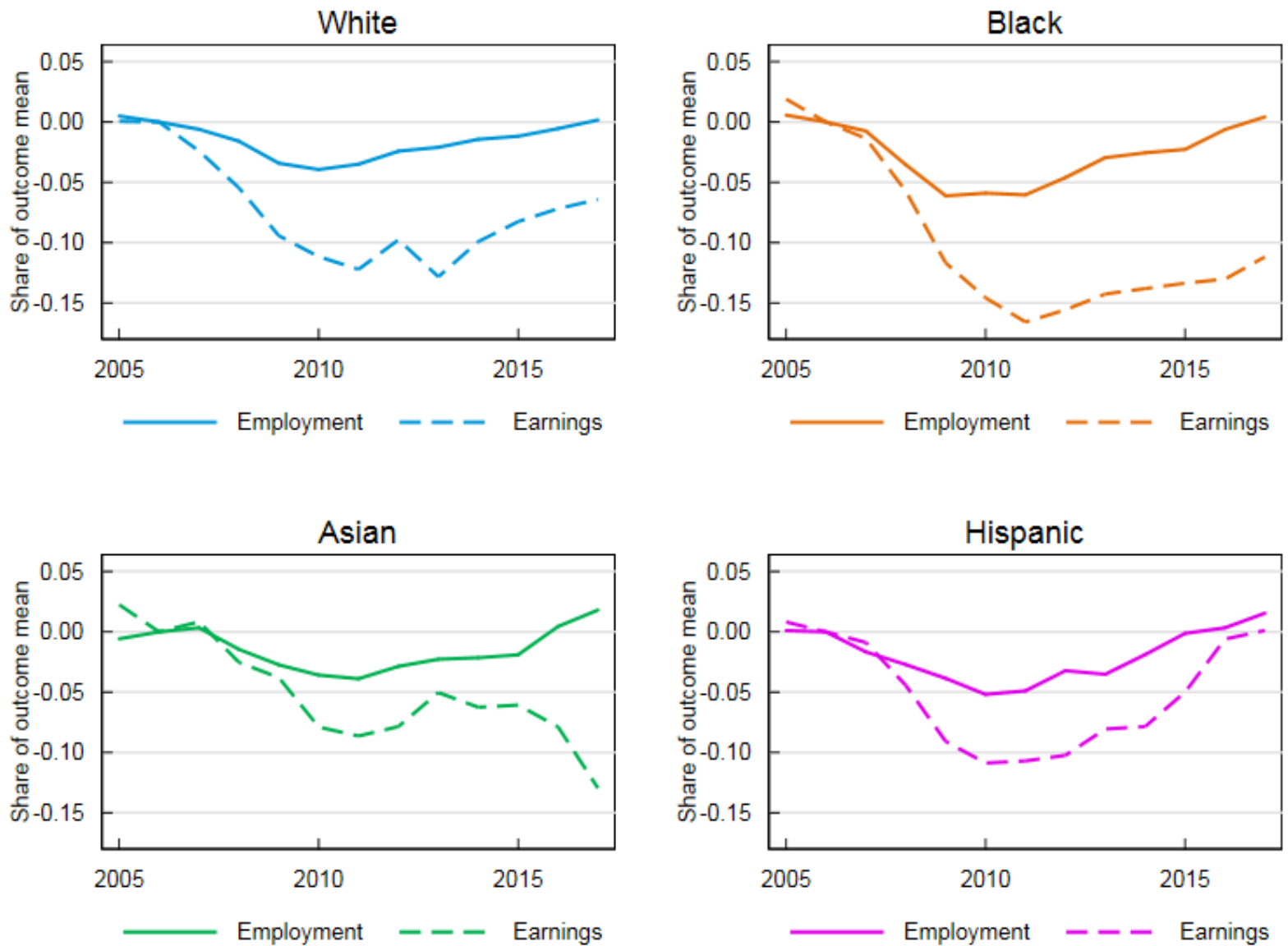

Source: Form 1040, Form 1099, Form W-2, Census Numident, American Community Survey (2001 through 2017), Decennial Census (2000 and 2010), MAF-ARF. Release authorization number CBDRB-FY19-431.

Note: Points plotted are $\beta$ coefficients as estimated in Equation 1 , multiplied by the magnitude of the average local unemployment shock and then divided by the mean of the corresponding outcome for the relevant group and year. 
Figure B11: Effects of Local Concentration Shocks on Employment and Earnings, as Shares of Outcome Means
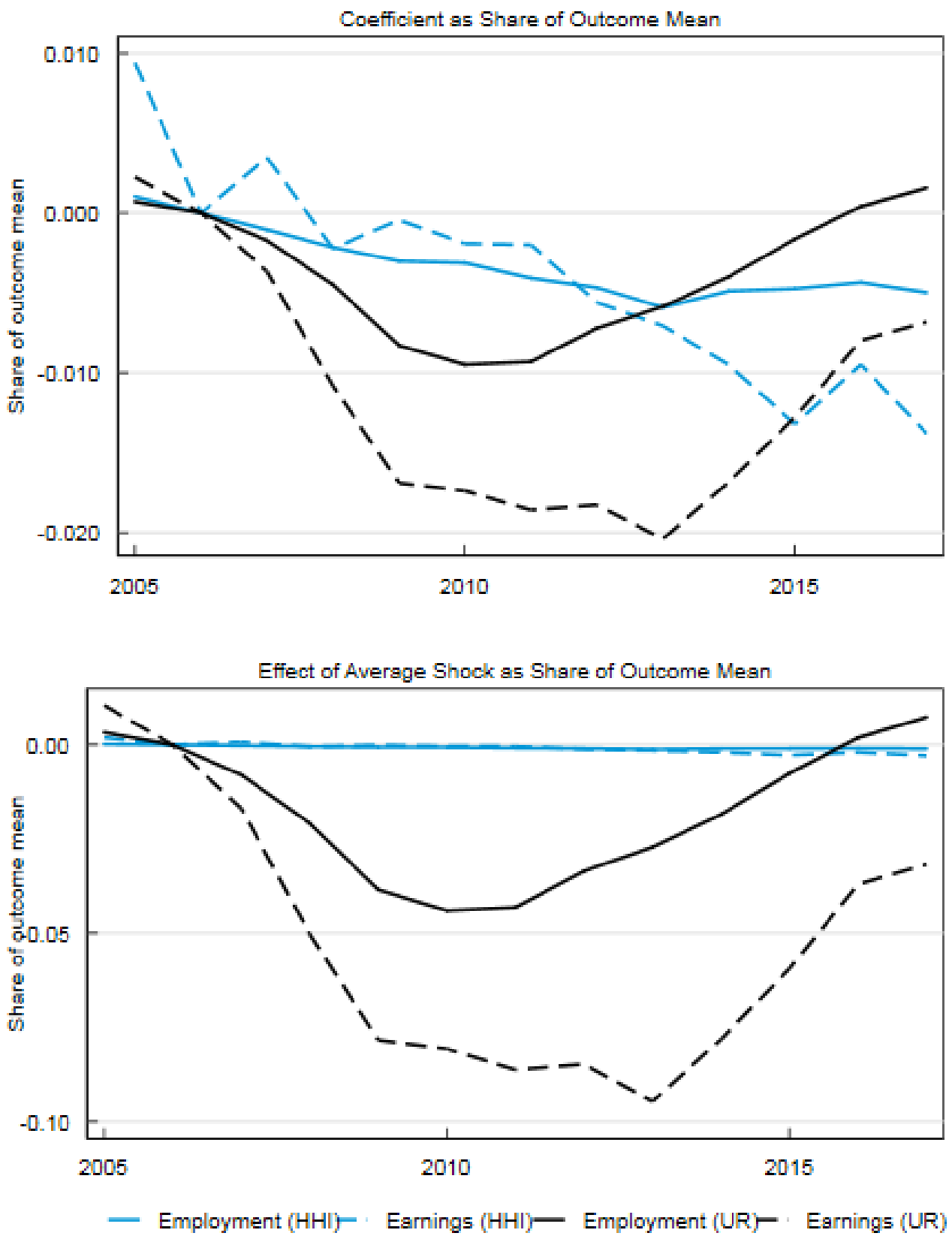

Source: Form 1040, Form 1099, Form W-2, Census Numident, American Community Survey (2001 through 2017), Decennial Census (2000 and 2010), MAF-ARF. Release authorization number CBDRB-FY19-500.

Note: Points plotted in blue are $\beta$ coefficients as estimated in Equation 4 divided by the mean of the corresponding outcome for the relevant group and year. Points plotted in black are the effects of local unemployment shocks from the same estimating equation (the $\zeta$ coefficients), also divided by outcome means, for reference. 
Figure B12: Effects of Local Concentration Shocks on Employment and Earnings, Coefficients as Shares of Outcome Means, by Generation
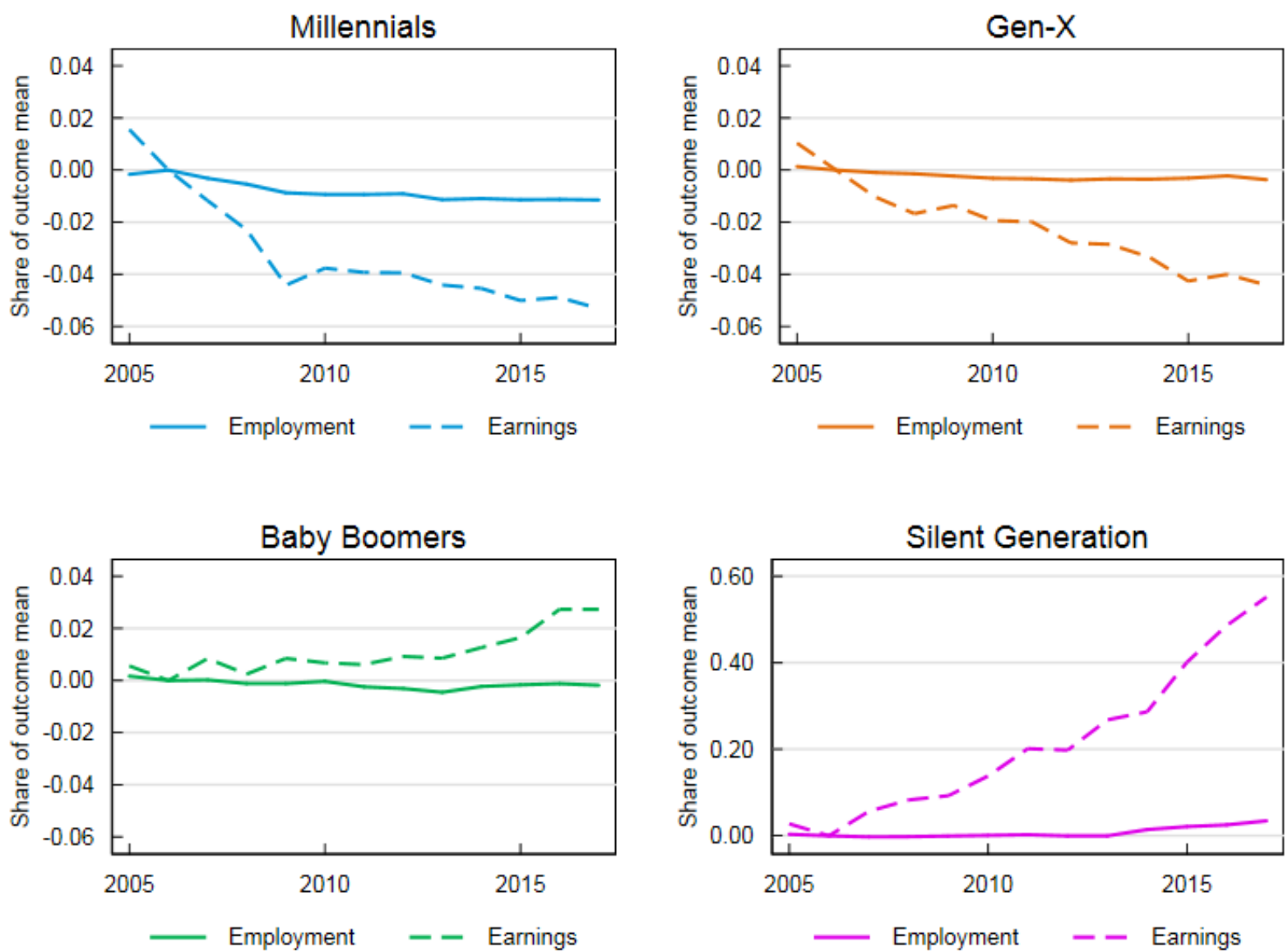

Source: Form 1040, Form 1099, Form W-2, Census Numident, American Community Survey (2001 through 2017), Decennial Census (2000 and 2010), MAF-ARF. Release authorization number CBDRB-FY19-376.

Note: Points plotted are $\beta$ coefficients as estimated in Equation 4, divided by the mean of the corresponding outcome for the relevant group and year. 
Figure B13: Effects of Local Concentration Shocks on Employment and Earnings, Effects of Average Shock as Shares of Mean Outcomes, by Generation
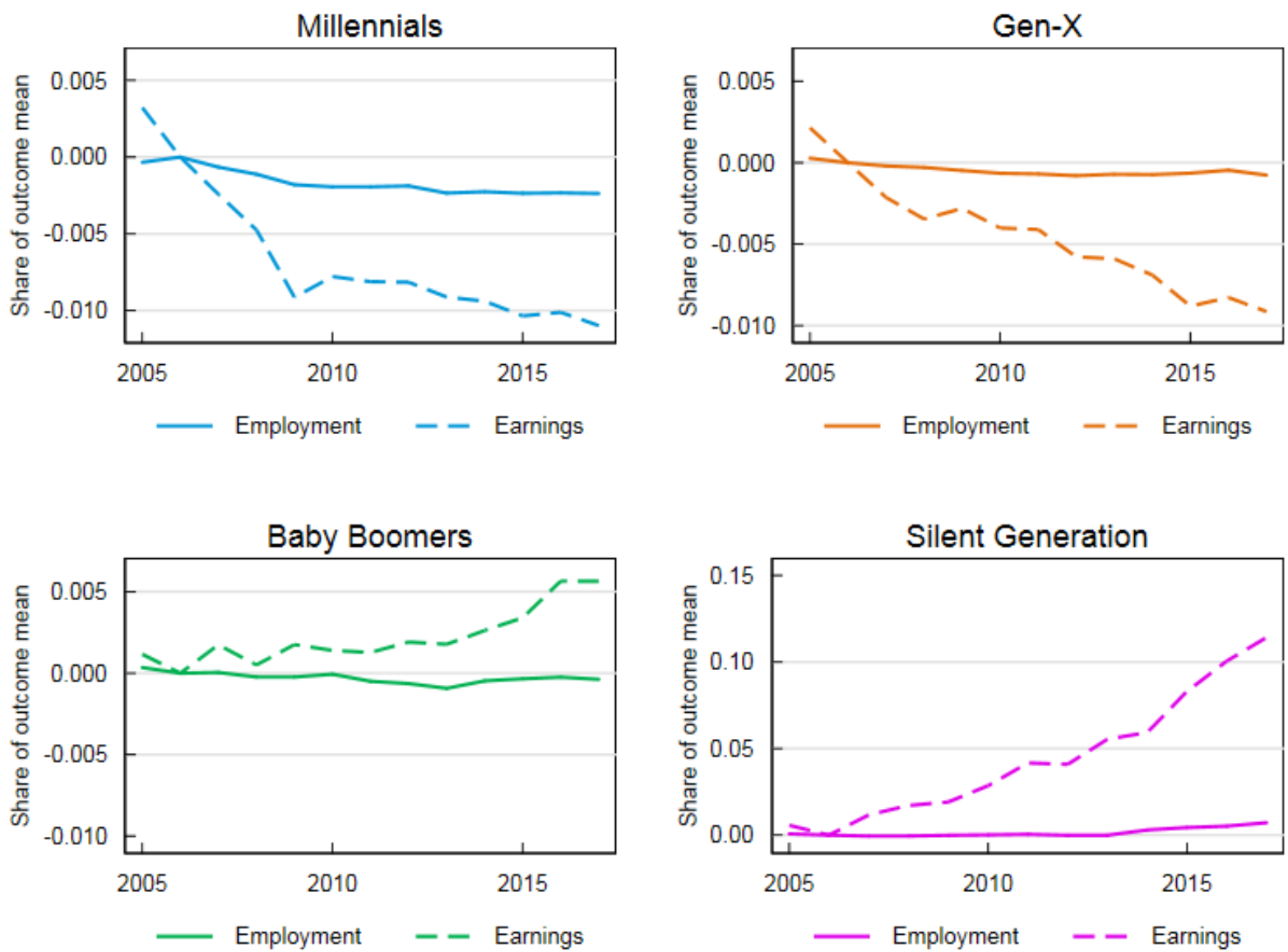

Source: Form 1040, Form 1099, Form W-2, Census Numident, American Community Survey (2001 through 2017), Decennial Census (2000 and 2010), MAF-ARF. Release authorization number CBDRB-FY19-376.

Note: Points plotted are $\beta$ coefficients as estimated in Equation 4 , multiplied by the magnitude of the average local unemployment shock and then divided by the mean of the corresponding outcome for the relevant group and year. 
Figure B14: Effects of Local Unemployment Shocks on Employment and Earnings, Coefficients as Shares of Mean Outcomes, Conditional on Concentration and Bartik Shocks, by Generation
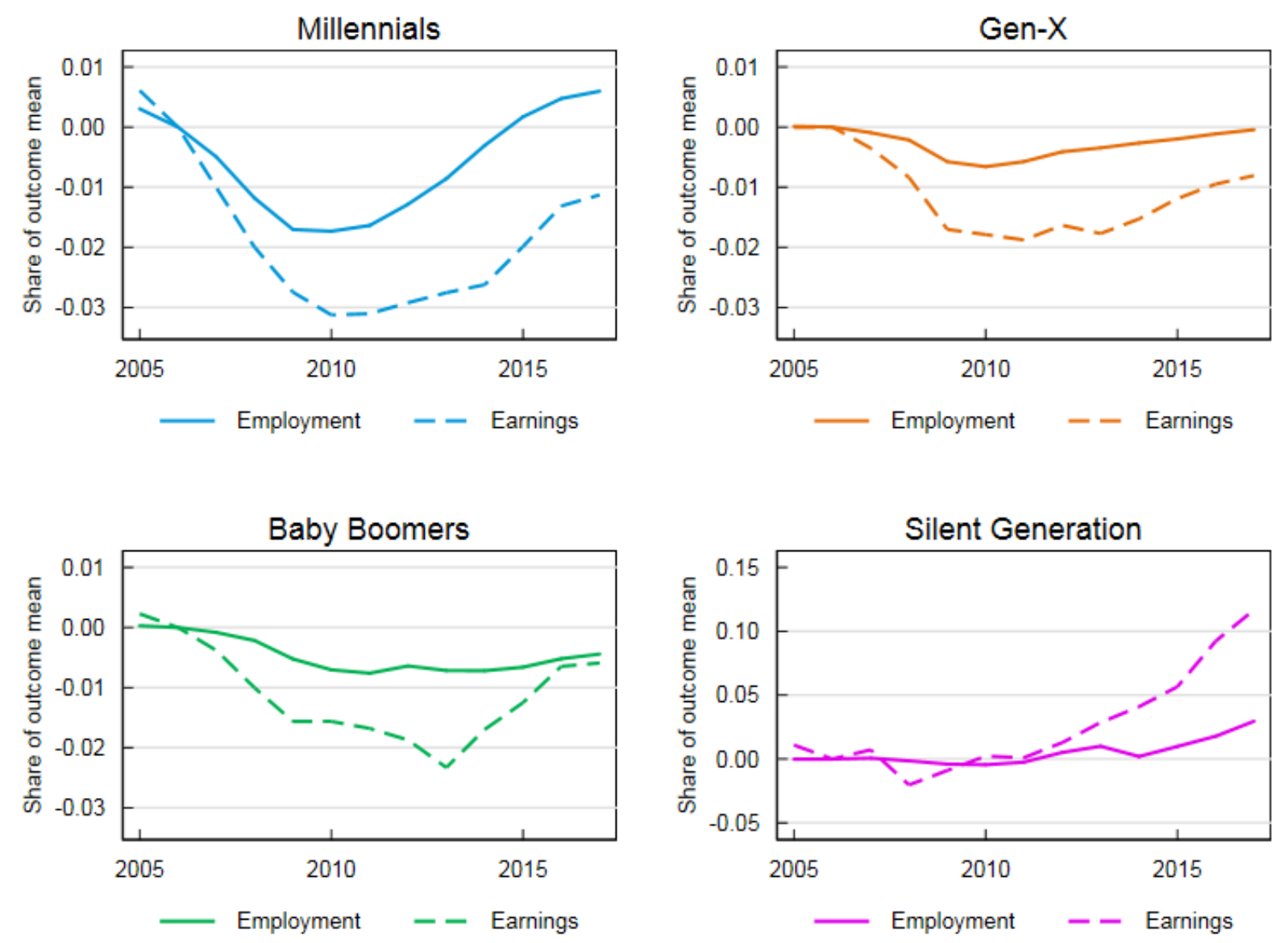

Source: Form 1040, Form 1099, Form W-2, Census Numident, American Community Survey (2001 through 2017), Decennial Census (2000 and 2010 ), MAF-ARF. Release authorization number CBDRB-FY19-376.

Note: Points plotted are $\beta$ coefficients as estimated in Equation 1. divided by the mean of the corresponding outcome for the relevant group and year. 
Figure B15: Effects Local Concentration Shocks on Employment and Earnings, Effects of Average Shock as Shares of Mean Outcomes, Conditional on Concentration and Bartik Shocks, by Generation
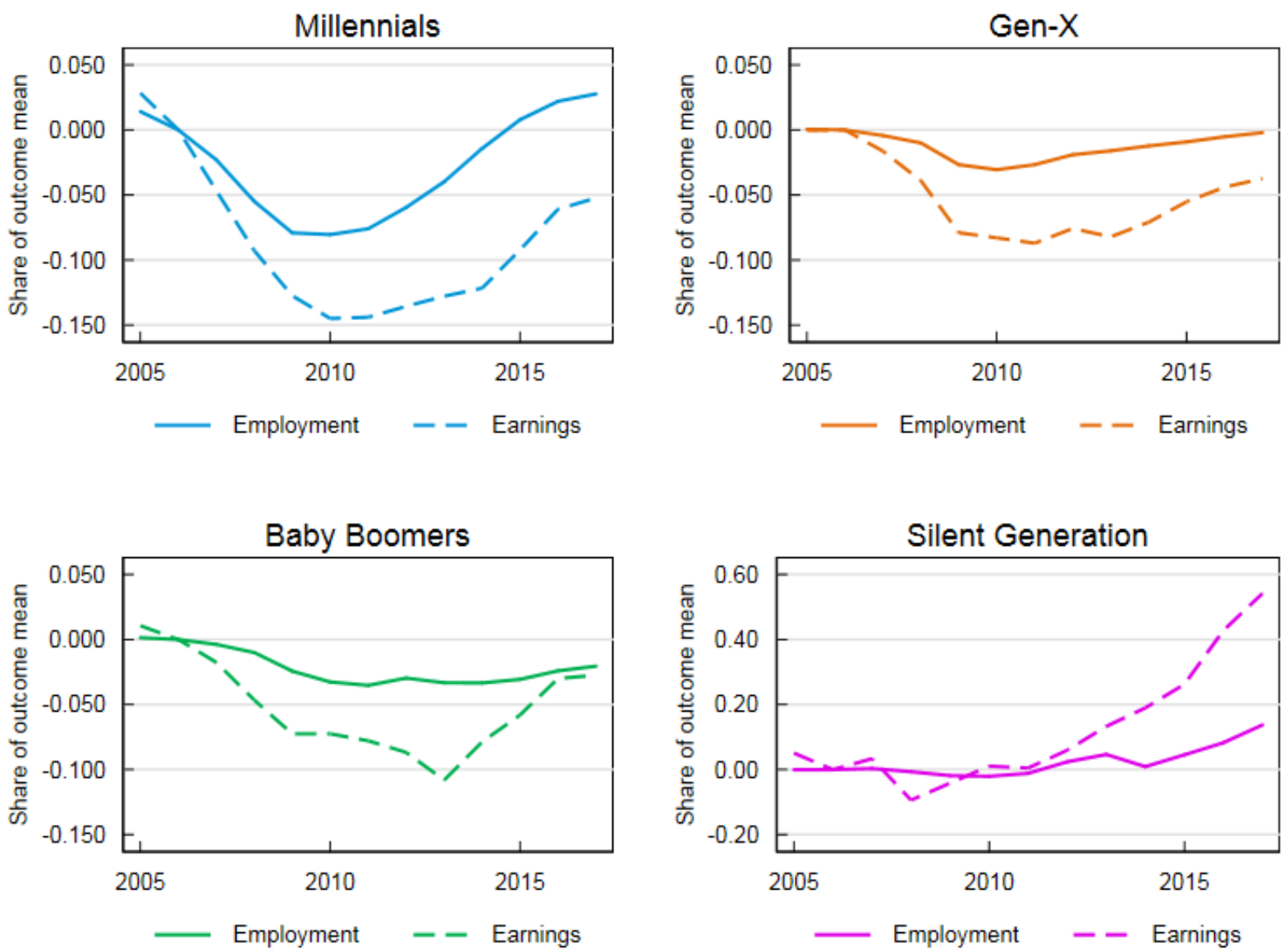

Source: Form 1040, Form 1099, Form W-2, Census Numident, American Community Survey (2001 through 2017), Decennial Census (2000 and 2010 ), MAF-ARF. Release authorization number CBDRB-FY19-376.

Note: Points plotted are $\beta$ coefficients as estimated in Equation 1 , multiplied by the magnitude of the average local unemployment shock and then divided by the mean of the corresponding outcome for the relevant group and year. 
Figure B16: Employment and Earnings Trends, Millennials
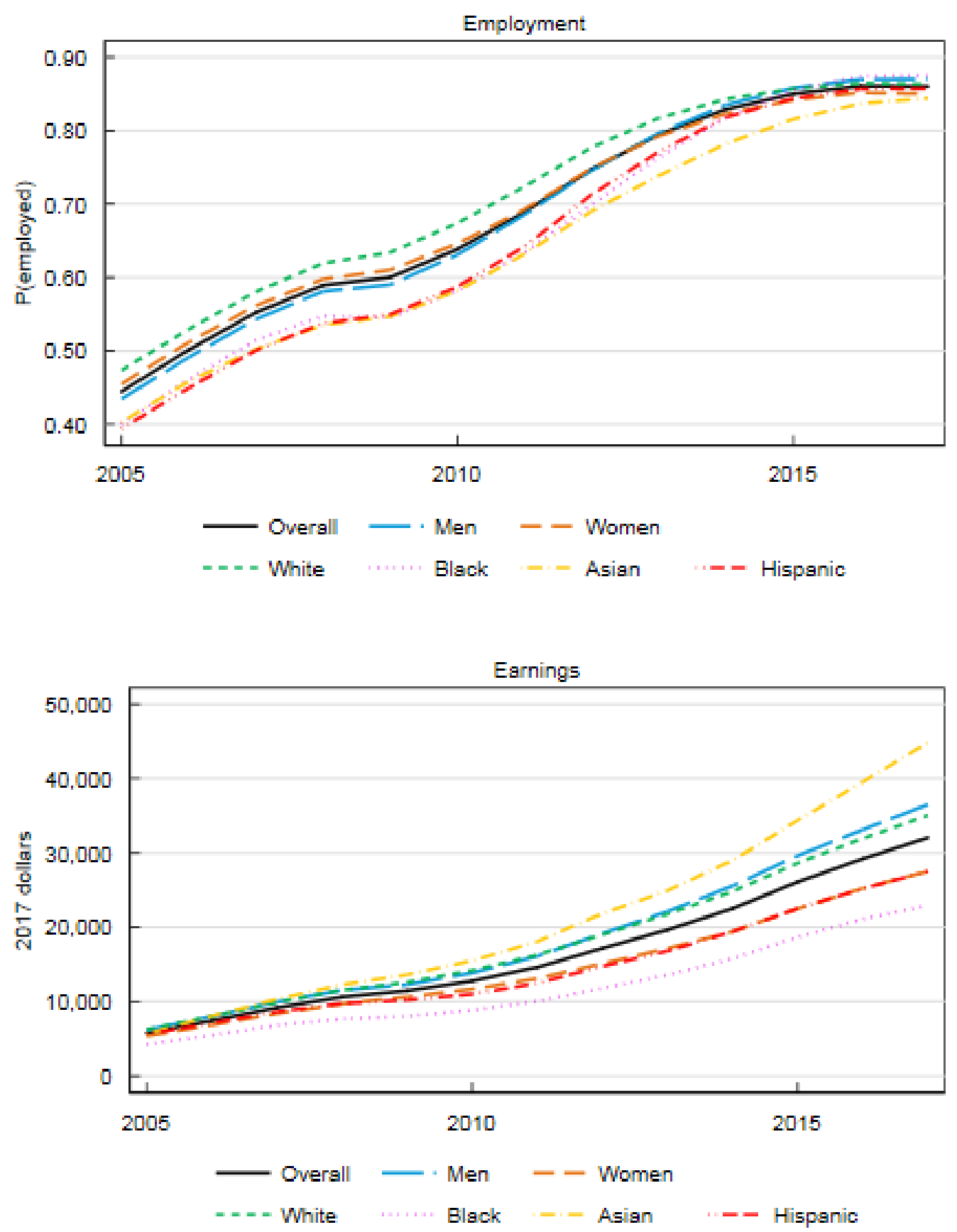

Source: Form W-2, Census Numident. Release authorization number CBDRB-FY19-376.

Note: Individuals are employed if they have any W-2 earnings in a given year. Earnings include wage and salary income as well as deferred compensation. 
Figure B17: Employment and Earnings Trends, Generation X
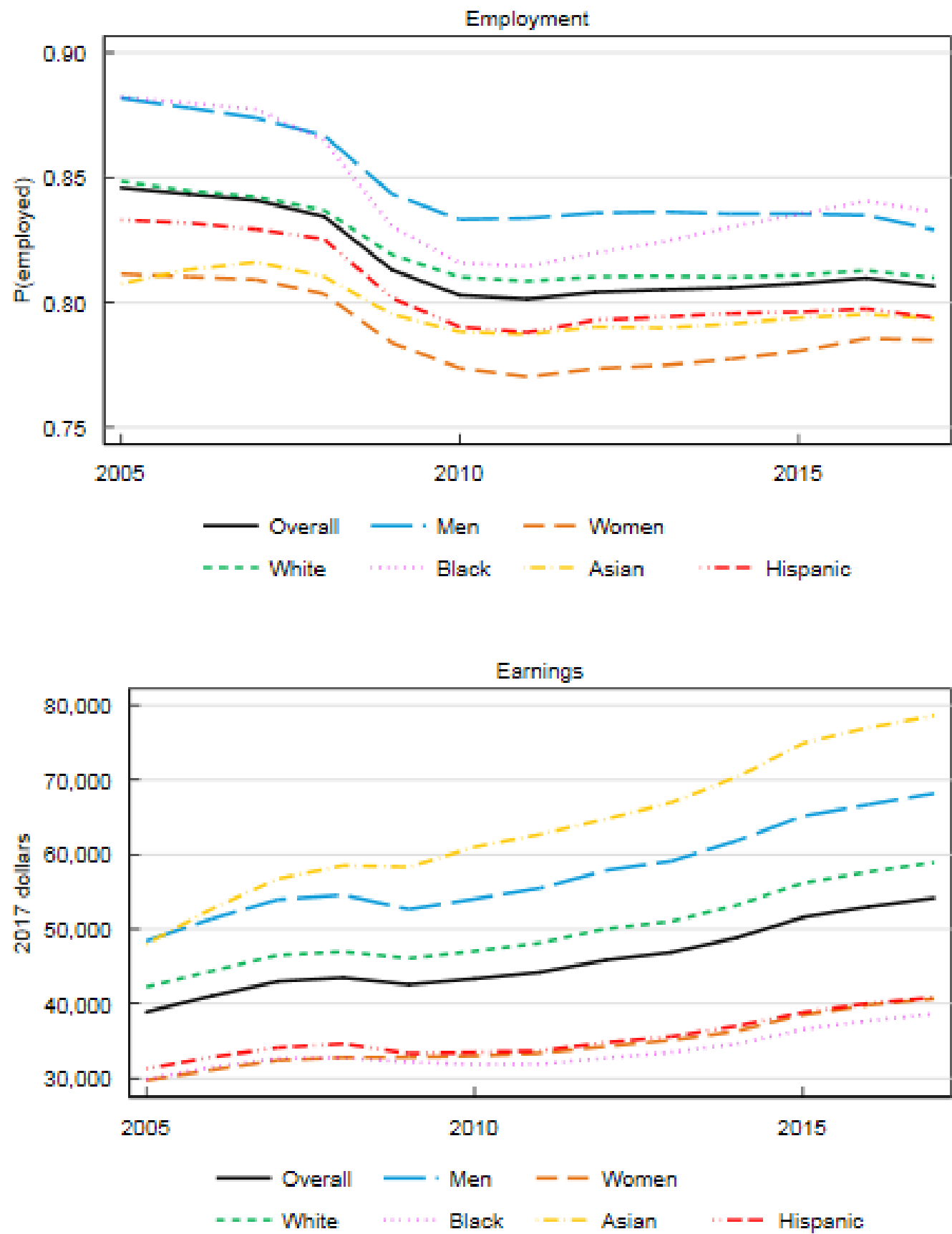

Source: Form W-2, Census Numident. Release authorization number CBDRB-FY19-376.

Note: Individuals are employed if they have any W-2 earnings in a given year. Earnings include wage and salary income as well as deferred compensation. 
Figure B18: Employment and Earnings Trends, Baby Boomers
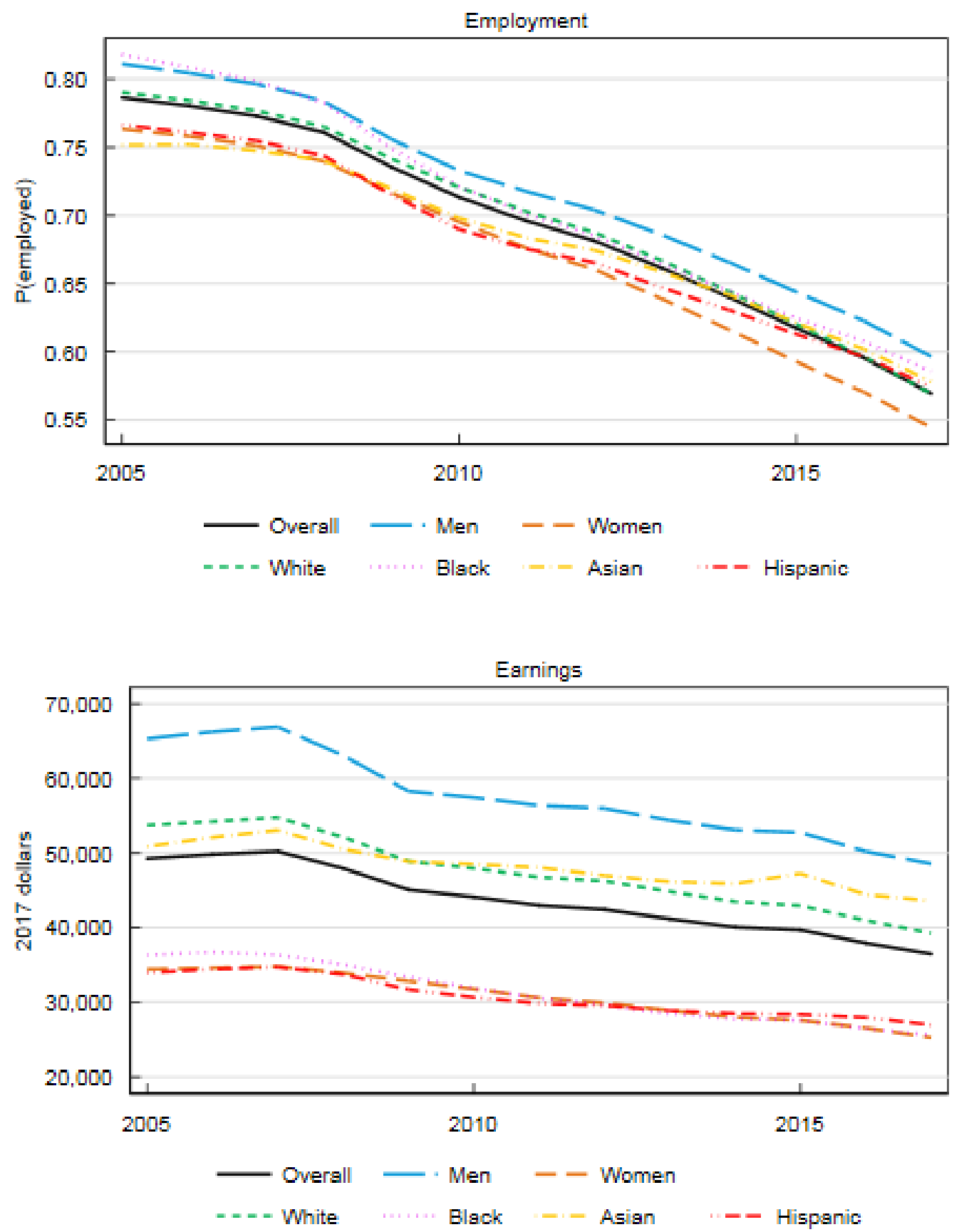

Source: Form W-2, Census Numident. Release authorization number CBDRB-FY19-376.

Note: Individuals are employed if they have any W-2 earnings in a given year. Earnings include wage and salary income as well as deferred compensation. 
Figure B19: Employment and Earnings Trends, Silent Generation
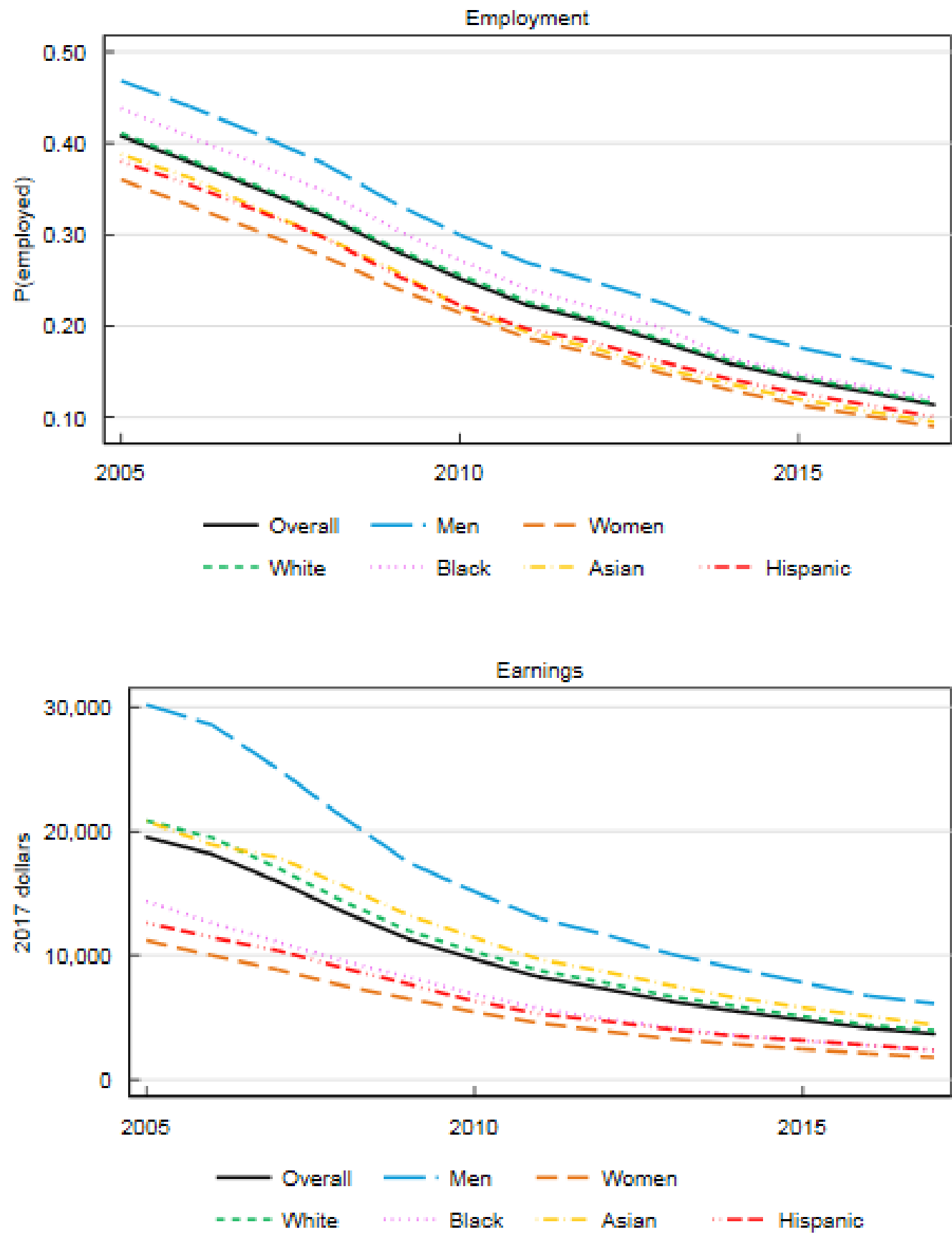

Source: Form W-2, Census Numident. Release authorization number CBDRB-FY19-376.

Note: Individuals are employed if they have any W-2 earnings in a given year. Earnings include wage and salary income as well as deferred compensation. 
Table B1: Point Estimates as Percents of Outcome Means

\begin{tabular}{|c|c|c|c|c|c|c|c|c|}
\hline & (1) 2010 & $(2)$ & (3) 2012 & (4) & (5) 201 & (6) & (7) & (8) \\
\hline & Employment & Earnings & Employment & Earnings & Employment & Earnings & Employment & Earnings \\
\hline Overall & -1.07 & -2.16 & -0.76 & -2.03 & -0.29 & -1.68 & -0.04 & -1.26 \\
\hline Male & -1.17 & -2.85 & -0.73 & -2.42 & -0.23 & -1.89 & 0.14 & -1.37 \\
\hline $\begin{array}{l}\text { Female } \\
\text { White }\end{array}$ & $\begin{array}{l}-0.83 \\
-0.85\end{array}$ & $\begin{array}{l}-1.9 \\
-2.4\end{array}$ & $\begin{array}{l}-0.57 \\
-0.52\end{array}$ & -2.08 & $\begin{array}{l}-0.24 \\
-0.25\end{array}$ & -1.88 & 0.1 & -1.59 \\
\hline Black & -1.27 & -3.14 & -0.99 & -3.35 & -0.49 & $\begin{array}{l}-1.88 \\
-2.88\end{array}$ & 0.09 & $\begin{array}{l}-1.00 \\
-2.41\end{array}$ \\
\hline Asian & -0.77 & -1.7 & -0.62 & -1.69 & -0.41 & -1.31 & 0.39 & -2.79 \\
\hline Hispanic & -1.12 & -2.34 & -0.69 & -2.21 & -0.03 & -1.08 & 0.33 & 0.02 \\
\hline Not employed in 2006 & -3.82 & -2.94 & -2.7 & -3.06 & -0.82 & -2.32 & -0.36 & -1.78 \\
\hline Some full-year nonemployment & -1.61 & -6.56 & -0.61 & -4.38 & -0.04 & -3.17 & 0.19 & -2.43 \\
\hline $\begin{array}{l}\text { Main employer change } \\
\text { Kept same main employer }\end{array}$ & $\begin{array}{l}-0.43 \\
-0.41\end{array}$ & -2.43 & $\begin{array}{l}-0.32 \\
-0.42\end{array}$ & -2.13 & -0.36 & -1.77 & -0.24 & -1.26 \\
\hline Place, Equation 3 & -1.25 & -2.18 & -0.98 & -2.18 & -0.64 & -1.9 & -0.41 & $\begin{array}{l}-1.00 \\
-1.39\end{array}$ \\
\hline HHI Shock, Equation 4 & -0.31 & -0.19 & -0.47 & -0.56 & -0.47 & -1.32 & -0.5 & -1.38 \\
\hline UR Shock, Equation 4 & -0.95 & -1.74 & -0.72 & -1.83 & -0.16 & -1.28 & 0.16 & -0.68 \\
\hline Millennials & -1.87 & -3.73 & -1.21 & -3.29 & 0.02 & -2.55 & 0.32 & -1.94 \\
\hline Male & -1.89 & -4.26 & -1.16 & -3.62 & 0.22 & -2.68 & 0.46 & -1.86 \\
\hline Female & -1.64 & -3.3 & -1.02 & -3.07 & 0.11 & -2.78 & 0.42 & -2.2 \\
\hline White & -1.53 & -3.83 & -0.75 & -3.45 & 0.17 & -2.76 & 0.29 & -2.13 \\
\hline Black & -1.72 & -3.2 & -1.28 & -2.98 & 0.14 & -2.45 & 0.6 & -1.9 \\
\hline Asian & -1.66 & -2.71 & -1.9 & -2.94 & -0.88 & -3.65 & 0.31 & -3.72 \\
\hline Hispanic & -2.1 & -2.58 & -1.69 & -1.65 & 0.21 & -0.66 & 0.56 & 0.8 \\
\hline Not employed in 2006 & -5.19 & -4.35 & -3.21 & -3.39 & -0.65 & -2.18 & -0.22 & -1.49 \\
\hline Some full-year nonemployment & -2.15 & -8 & -0.99 & -5.27 & -0.03 & -4.21 & 0.28 & -3.81 \\
\hline ployer change & -0.43 & -3.25 & -0.26 & -3.07 & -0.13 & -2.37 & -0.04 & -1.85 \\
\hline Kept same main employer & -0.36 & -2.26 & -0.24 & -1.98 & -0.17 & -1.84 & -0.11 & -1.35 \\
\hline Place, Equation 3 . & -1.84 & -4.55 & -1.02 & -4.19 & 0.35 & -3.04 & 0.7 & -2.04 \\
\hline HHI Shock, Equation 4 & -0.93 & -3.76 & -0.91 & $\begin{array}{r}-3.94 \\
292\end{array}$ & -1.14 & -5 & -1.14 & -5.31 \\
\hline Gen-X Shock, Equation 4 & $\begin{array}{l}-1.73 \\
-0.74\end{array}$ & $\begin{array}{l}-3.12 \\
-2.35\end{array}$ & $\begin{array}{l}-1.28 \\
-0.49\end{array}$ & $\begin{array}{l}-2.92 \\
-2.11\end{array}$ & $\begin{array}{c}0.17 \\
-0.28\end{array}$ & $\begin{array}{l}-1.99 \\
-1.84\end{array}$ & 0.6 & -1.13 \\
\hline Male & -0.8 & -2.82 & -0.38 & -2.84 & $\begin{array}{ll}-0.20 \\
-0.21\end{array}$ & $\begin{array}{l}-1.84 \\
-2.69\end{array}$ & $\begin{array}{l}-0.14 \\
0.18\end{array}$ & $\begin{array}{l}-1.58 \\
-2.09\end{array}$ \\
\hline Female & -0.66 & -2.21 & $\begin{array}{l}-0.00 \\
-0.5\end{array}$ & -2.31 & -0.55 & -2.5 & -0.25 & -2.29 \\
\hline White & -0.6 & -2.36 & -0.41 & -2.32 & -0.39 & -2.57 & 0.01 & -2.08 \\
\hline Black & -1.43 & -4.65 & -1 & -5.81 & -0.66 & -5.17 & -0.42 & -4.55 \\
\hline Asian & -0.8 & -1.6 & -0.33 & -1.04 & 0.26 & -0.21 & 0.09 & -1.4 \\
\hline Hispanic & -0.49 & -2.34 & 0.1 & -2.2 & -0.25 & -0.73 & -0.06 & -0.15 \\
\hline Not employed in 2006 & -1.32 & -2.83 & -1.37 & -2.84 & -1.11 & -2.17 & -0.63 & -2.27 \\
\hline Some full-year nonemployment & -1.14 & -4.25 & 0.02 & -3.23 & 0.26 & -1.75 & 0.4 & -0.88 \\
\hline ployer change & -0.51 & -2.8 & -0.44 & -2.47 & -0.29 & -2.05 & -0.21 & -1.53 \\
\hline employer & -0.31 & -1.48 & -0.23 & -1.39 & -0.2 & -1.35 & -0.18 & -1.33 \\
\hline Place, Equation 3 & -0.8 & -2.18 & -0.55 & -2.03 & -0.38 & -1.85 & -0.26 & -1.51 \\
\hline HHI Shock, Equation 4 & -0.31 & -1.94 & -0.38 & -2.79 & -0.31 & -4.26 & -0.37 & -4.42 \\
\hline UR Shock, Equation 4 & -0.66 & -1.79 & -0.41 & -1.63 & -0.2 & -1.19 & -0.04 & -0.81 \\
\hline Baby Boomers & -0.8 & -1.8 & -0.67 & -1.75 & -0.69 & -1.38 & -0.51 & -0.81 \\
\hline Male & -0.95 & -3.04 & -0.79 & -2.21 & -0.81 & -1.6 & -0.46 & -1.21 \\
\hline Female & -0.55 & -1.46 & -0.47 & -1.77 & -0.59 & -1.17 & -0.29 & -0.75 \\
\hline White & -0.65 & -2.43 & -0.63 & -1.92 & -0.7 & -1.34 & -0.53 & -1.01 \\
\hline Black & -0.81 & -1.81 & -0.6 & -1.09 & -1.09 & -0.38 & 0.16 & -0.01 \\
\hline Asian & -0.85 & -2.77 & -0.62 & -3.77 & -1.39 & -3.06 & -0.02 & -5.87 \\
\hline Hispanic & -1.09 & -2.6 & -0.58 & -3.05 & -0.44 & -2.5 & 0.01 & -1.16 \\
\hline Not employed in 2006 & -0.72 & -1.53 & -0.86 & -2.84 & -1.2 & -3.19 & -0.82 & -2.83 \\
\hline Some full-year nonemployment & -1.36 & -5.25 & -0.7 & -3.5 & -0.4 & -2.46 & -0.1 & -1.4 \\
\hline Main employer change & -0.53 & -1.71 & -0.5 & -1.15 & -0.71 & -1.15 & -0.61 & -0.59 \\
\hline Kept same main employer & -0.41 & -1.53 & -0.49 & -1.9 & -0.74 & -1.73 & -0.82 & -1.46 \\
\hline Place, & -0.93 & -1.79 & -0.91 & -1.87 & -1.2 & -1.51 & -1.13 & -0.91 \\
\hline HHI Sh & -0.03 & 0.68 & -0.31 & 0.92 & -0.17 & 1.64 & -0.18 & 2.73 \\
\hline UR Shock, Equation 4 & -0.7 & -1.56 & -0.64 & -1.87 & -0.66 & -1.25 & -0.44 & -0.59 \\
\hline & & & & & & & ontinu & next pa \\
\hline
\end{tabular}


Table B1 - continued from previous page

\begin{tabular}{|c|c|c|c|c|c|c|c|c|}
\hline & \multicolumn{2}{|c|}{2010} & \multicolumn{2}{|c|}{2012} & \multicolumn{2}{|c|}{2015} & \multicolumn{2}{|c|}{2017} \\
\hline & Employment & Earnings & Employment & Earnings & Employment & Earnings & Employment & Earnings \\
\hline Silent Generation & -1.14 & -0.56 & -0.5 & 0.71 & -0.49 & 6.45 & 1.13 & 11.3 \\
\hline Male & -1.64 & 1.53 & -0.03 & 4.1 & -0.73 & 15.92 & 1.36 & 22.21 \\
\hline Female & 0.12 & 0.28 & 1.01 & 1.91 & 2.66 & 13.32 & 5.94 & 20.44 \\
\hline White & -1.1 & 0.44 & 0.44 & 2.63 & 1.01 & 14.67 & 3.64 & 20.99 \\
\hline Black & -0.82 & -2.99 & -2.62 & -4.51 & -5.31 & -4.83 & -7.16 & 0.33 \\
\hline Asian & 4.71 & 13.12 & 6.81 & 19.84 & 9.76 & 35.21 & 18.46 & 45.09 \\
\hline Hispanic & 2.57 & 2.16 & $\begin{array}{l}0.01 \\
4.02\end{array}$ & $\begin{array}{l}19.04 \\
3.72\end{array}$ & $\begin{array}{l}9.10 \\
4.06\end{array}$ & 8.86 & $\begin{array}{l}10.40 \\
8.67\end{array}$ & $\begin{array}{l}10.77 \\
10.79\end{array}$ \\
\hline Not employed in 2006 & $\begin{array}{l}2.38 \\
-3.86\end{array}$ & $\begin{array}{l}2.10 \\
-4.4\end{array}$ & -4.34 & -4.47 & 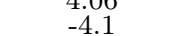 & $\begin{array}{l}.80 \\
-2.5\end{array}$ & $\begin{array}{l}0.07 \\
-3.26\end{array}$ & -0.85 \\
\hline Some full-year nonemployment & -3.53 & -27.74 & -3.52 & -20.4 & -2.44 & -26.19 & -2.76 & -31.23 \\
\hline Main employer change & $\begin{array}{l}-0.73 \\
-0.00\end{array}$ & 4.93 & 0.06 & 4.6 & -4.74 & 12.75 & -4.03 & 19.47 \\
\hline Kept same main employer & -0.84 & -2.26 & -1.23 & -2.65 & -2.36 & -0.8 & -2.24 & 0.65 \\
\hline Place, Equation 3 & -1.13 & 0.44 & -0.33 & 2.63 & -0.38 & 8.86 & 1.33 & 15.03 \\
\hline HHI Shock, Equation 4 & 0.09 & 13.82 & -0.03 & 19.79 & 2.12 & 40.14 & 3.47 & 55.19 \\
\hline UR Shock, Equation 18 & -0.45 & 0.23 & 0.52 & 1.28 & 0.98 & 5.66 & 2.96 & 11.68 \\
\hline
\end{tabular}

Source: Form 1040, Form 1099, Form W-2, Census Numident, American Community Survey (2001 through 2017), Decennial Census (2000 and 2010). Release authorization numbers CBDRB-FY19-376 and CBDRB-FY19-431.

Note: Each cell report the $\beta$ coefficient for the indicated group, outcome, and year, estimated using Equation 1 (unless otherwise indicated), as a share of the mean value of that outcome for that group in that year. Each row presents estimates from two regressions (with employment and earnings as the dependent variables) for a sinlge sample. Values are reported in percentage points. Indented rows report estimates for subgroups or alternative specifications of the generation under which they are listed. 


\section{B.2 $\log ($ Earnings $)$}

Figure B20: Effects of Local Unemployment Shocks on Log Earnings, 1957-1976 Birth Cohorts

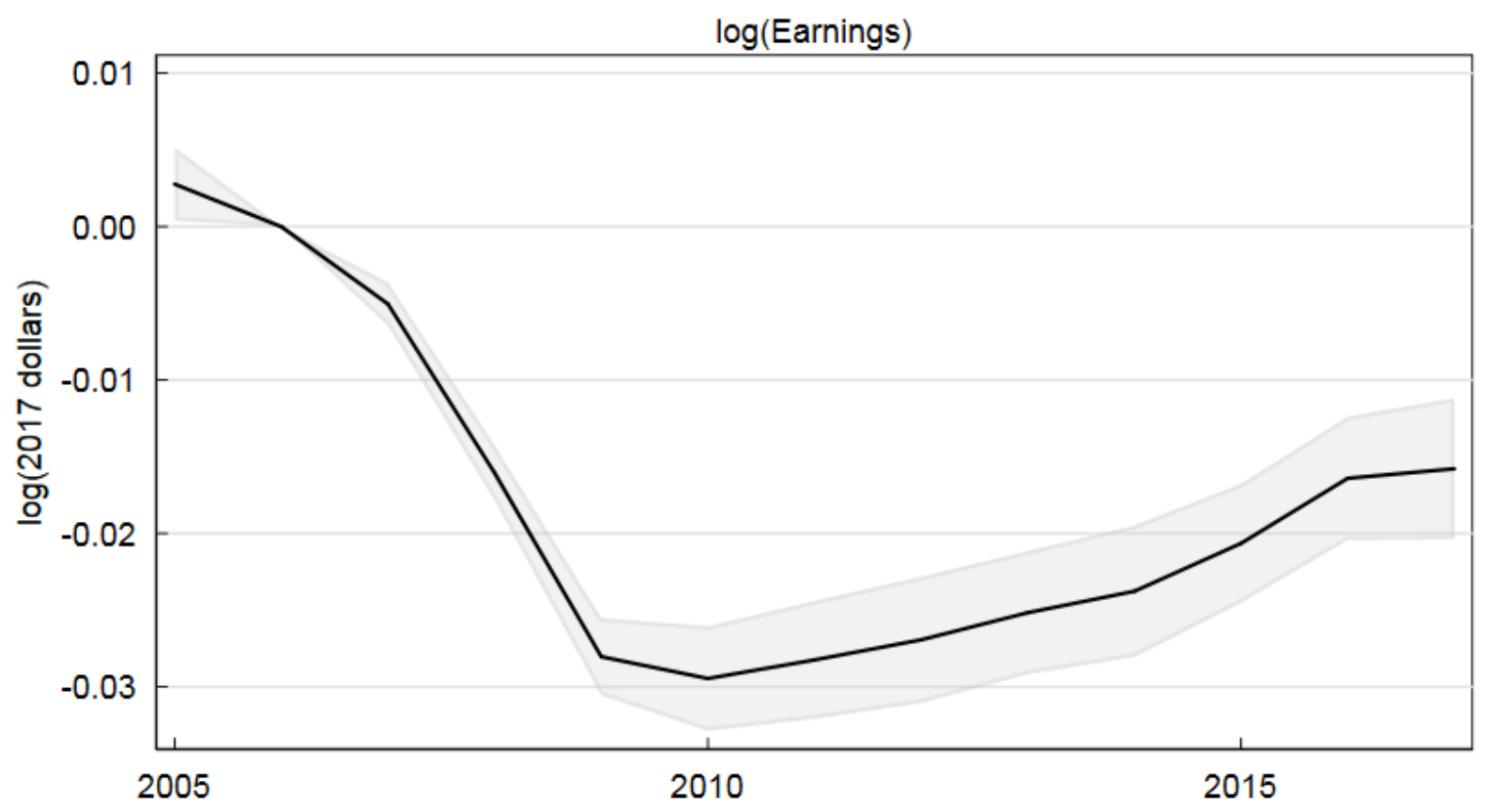

Source: Form 1040, Form 1099, Form W-2, Census Numident, American Community Survey (2001 through 2017), Decennial Census (2000 and 2010), MAF-ARF. Release authorization number CBDRB-FY19-376.

Note: Points plotted are $\beta$ coefficients as estimated in Equation 1 Shaded regions represent 95 percent confidence intervals. 
Figure B21: Effects of Local Unemployment Shocks on Log Earnings, 1928-1996 Birth Cohorts

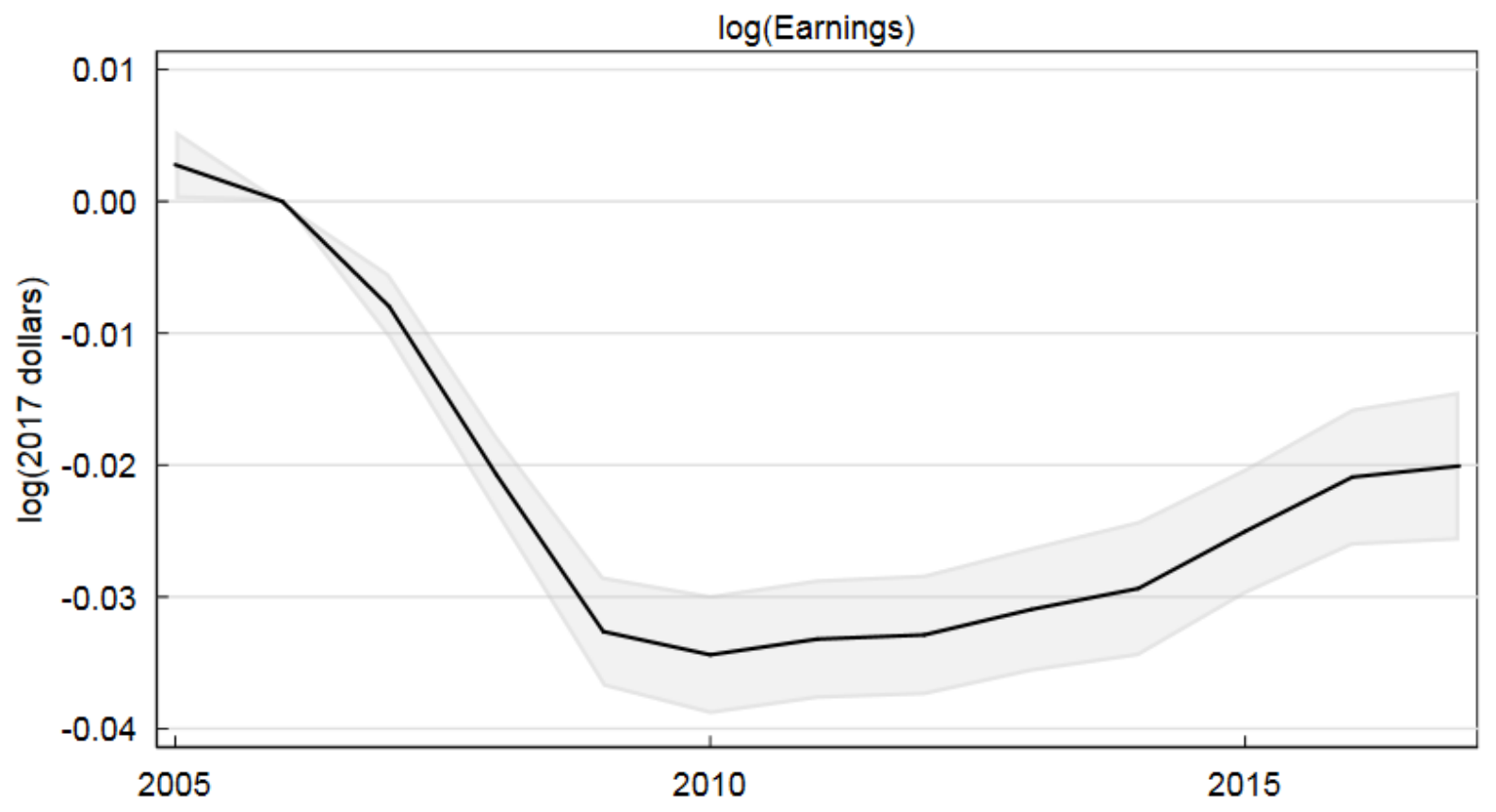

Source: Form 1040, Form 1099, Form W-2, Census Numident, American Community Survey (2001 through 2017), Decennial Census (2000 and 2010), MAF-ARF. Release authorization number CBDRB-FY19-376.

Note: Points plotted are $\beta$ coefficients as estimated in Equation 1 Shaded regions represent 95 percent confidence intervals. 
Figure B22: Effects of Local Unemployment Shocks on Log Earnings, by Generation
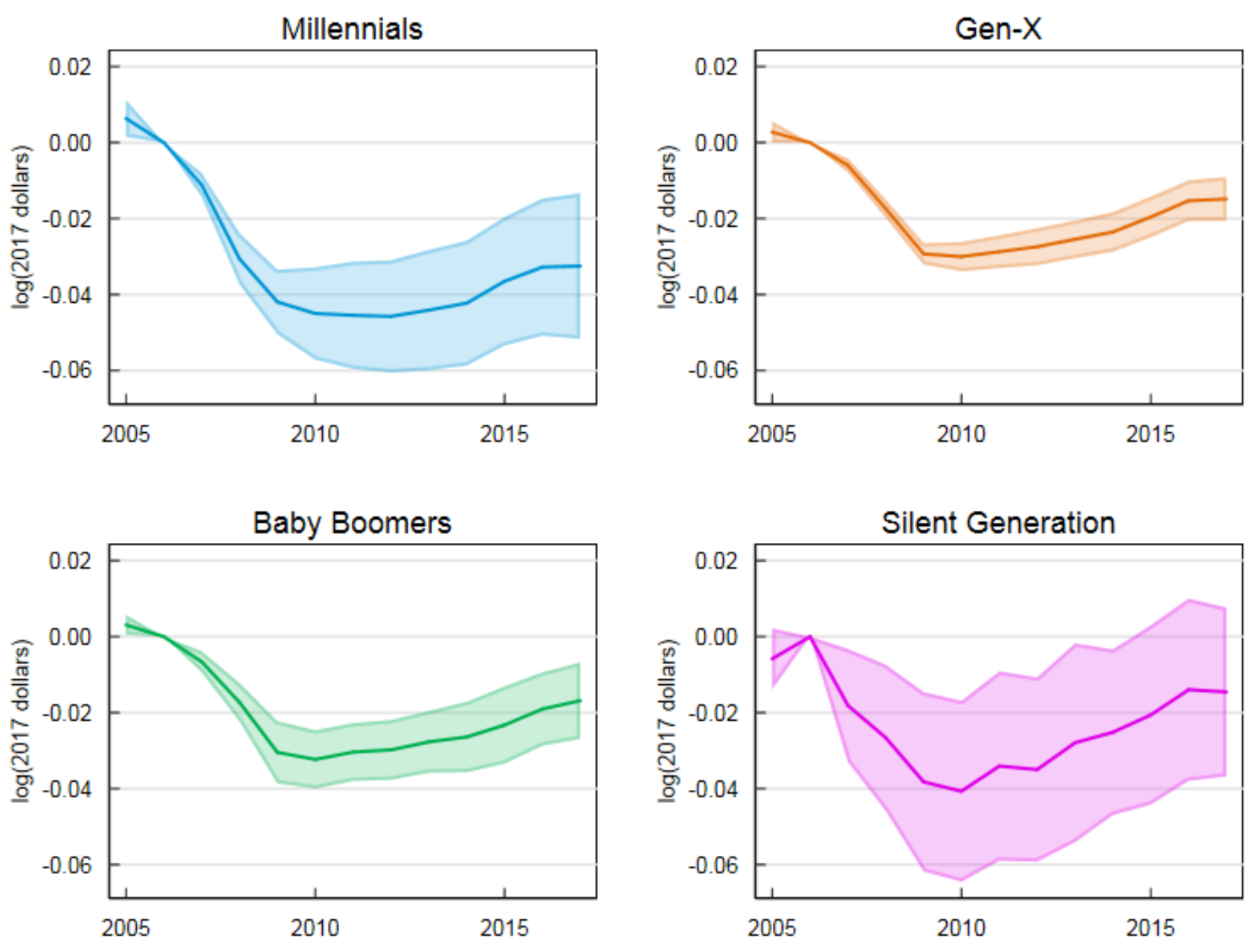

Source: Form 1040, Form 1099, Form W-2, Census Numident, American Community Survey (2001 through 2017), Decennial Census (2000 and 2010), MAF-ARF Release authorization number CBDRB-FY19-376.

Note: Points plotted are $\beta$ coefficients as estimated in Equation 1. Shaded regions represent 95 percent confidence intervals. 
Figure B23: Effects of Local Unemployment Shocks on Log Earnings, by Displacement Status
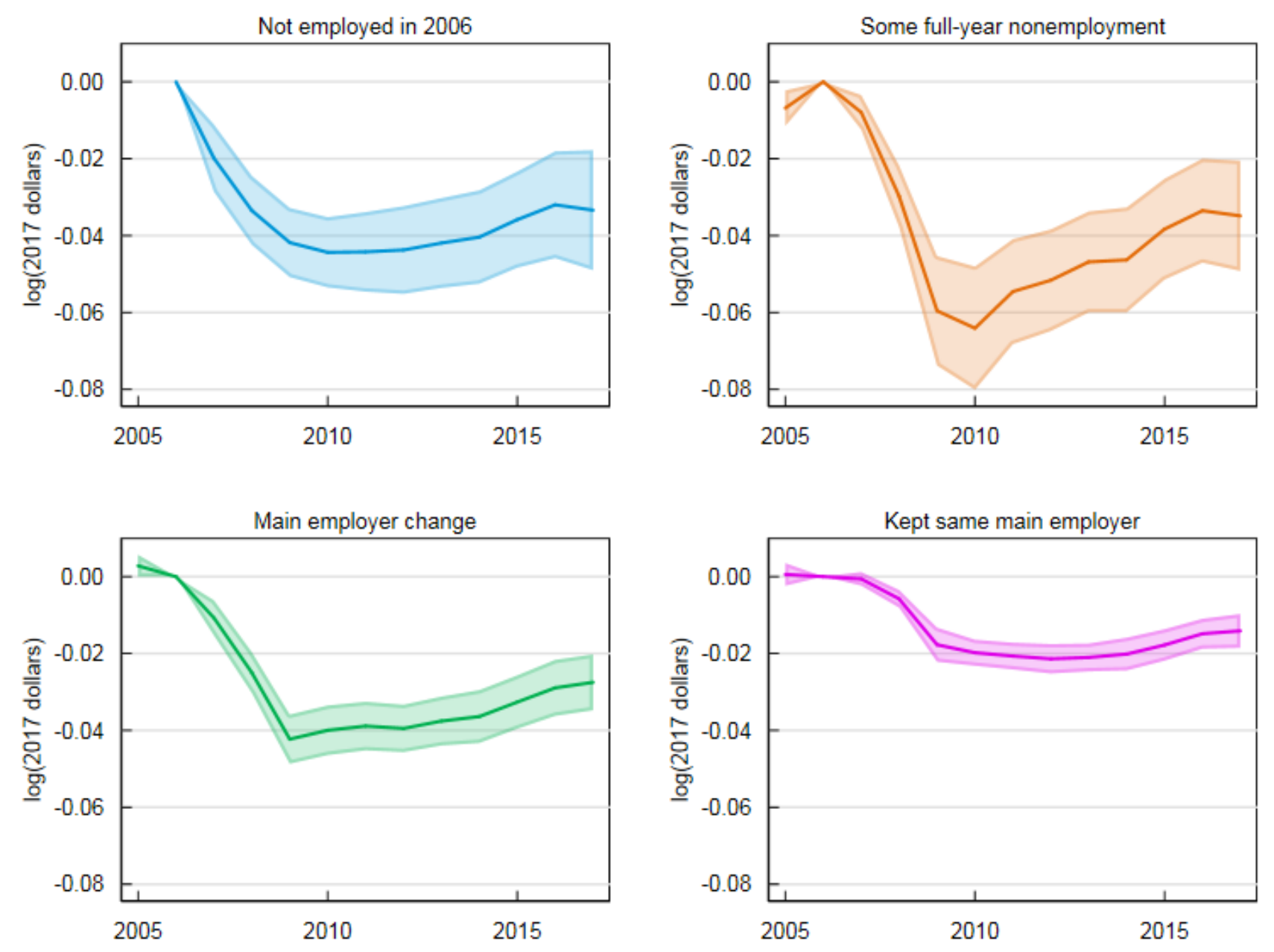

Source: Form 1040, Form 1099, Form W-2, Census Numident, American Community Survey (2001 through 2017), Decennial Census (2000 and 2010), MAF-ARF. Release authorization number CBDRB-FY19-376.

Note: Points plotted are $\beta$ coefficients as estimated in Equation 1. Shaded regions represent 95 percent confidence intervals. 
Figure B24: Effects of Local Unemployment Shocks on Log Earnings, by Gender

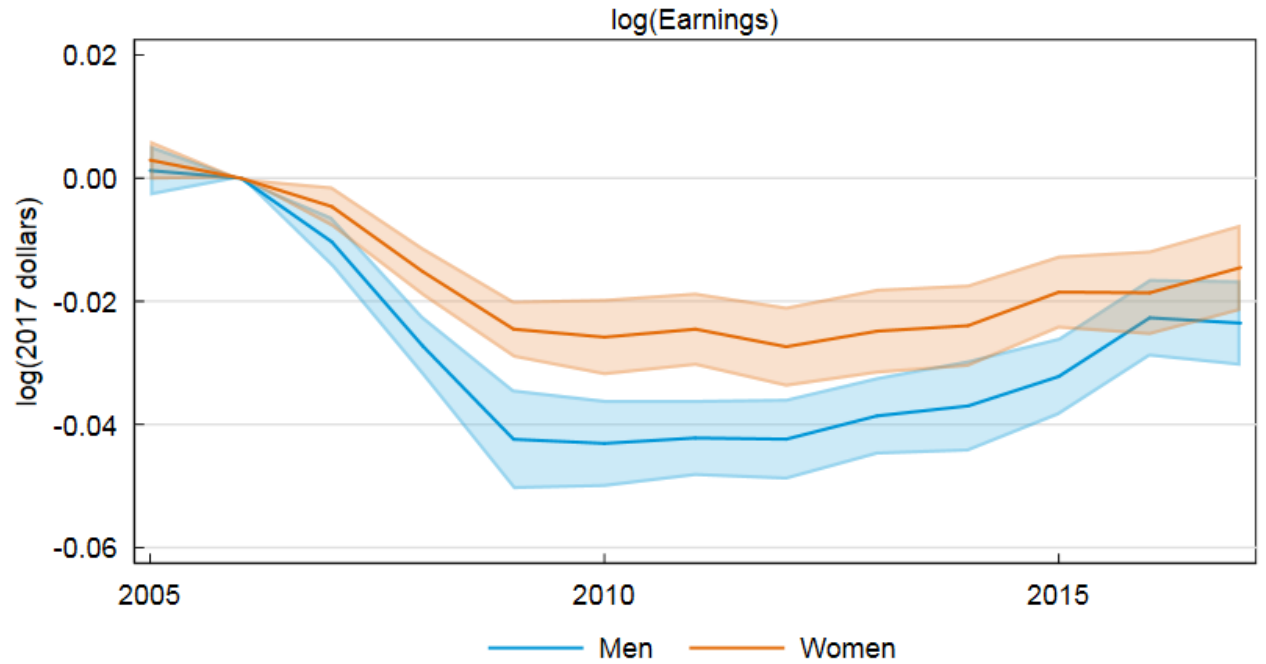

Source: Form 1040, Form 1099, Form W-2, Census Numident, American Community Survey (2001 through 2017), Decennial Census (2000 and 2010), MAF-ARF. Release authorization number CBDRB-FY19-376.

Note: Points plotted are $\beta$ coefficients as estimated in Equation 1 Shaded regions represent 95 percent confidence intervals. 
Figure B25: Effects of Local Unemployment Shocks on Log Earnings, by Gender and by Generation
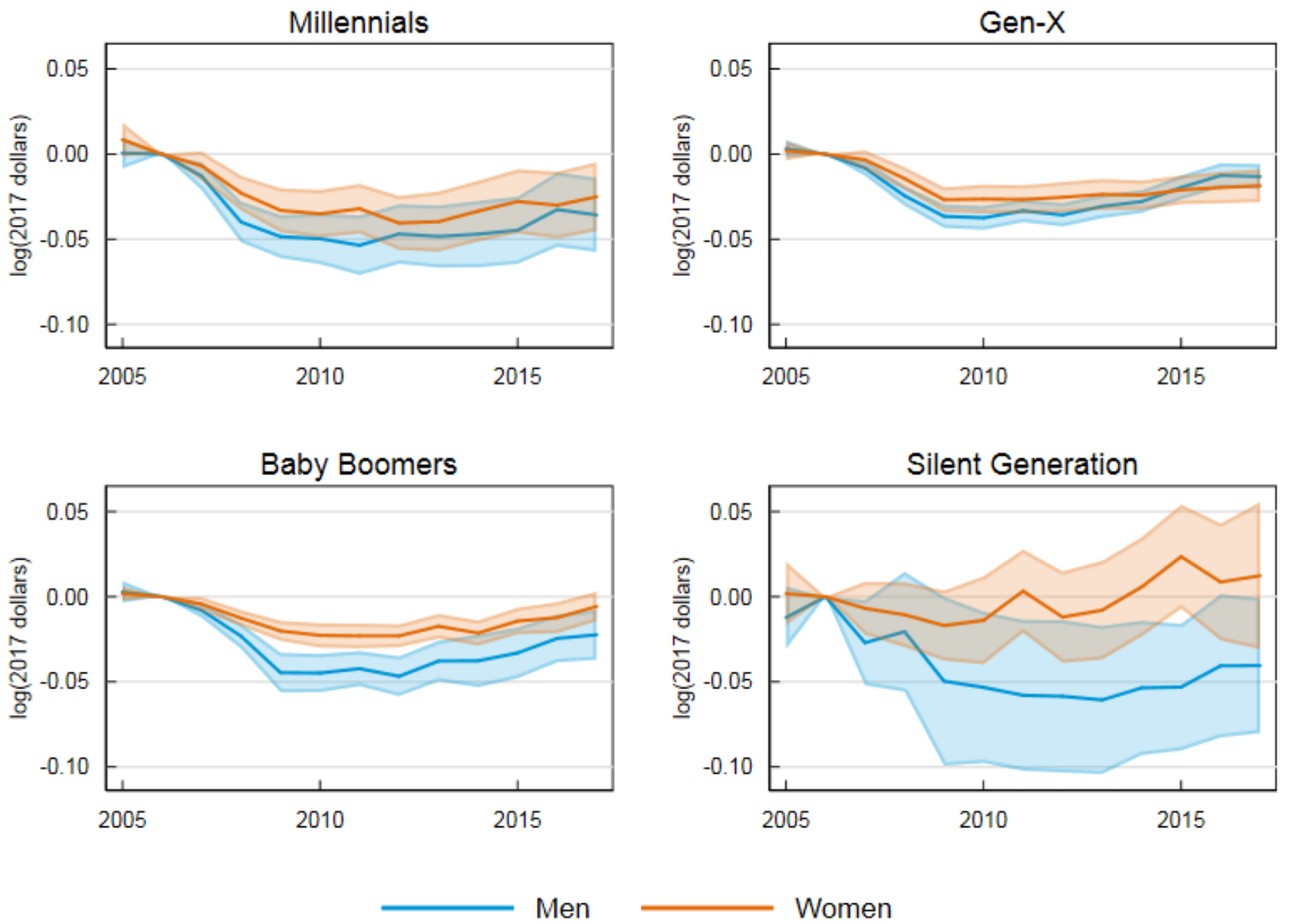

Source: Form 1040, Form 1099, Form W-2, Census Numident, American Community Survey (2001 through 2017), Decennial Census (2000 and 2010), MAF-ARF. Release authorization number CBDRB-FY19-376.

Note: Points plotted are $\beta$ coefficients as estimated in Equation 1. Shaded regions represent 95 percent confidence intervals. 
Figure B26: Effects of Local Unemployment Shocks on Log Earnings, by Race
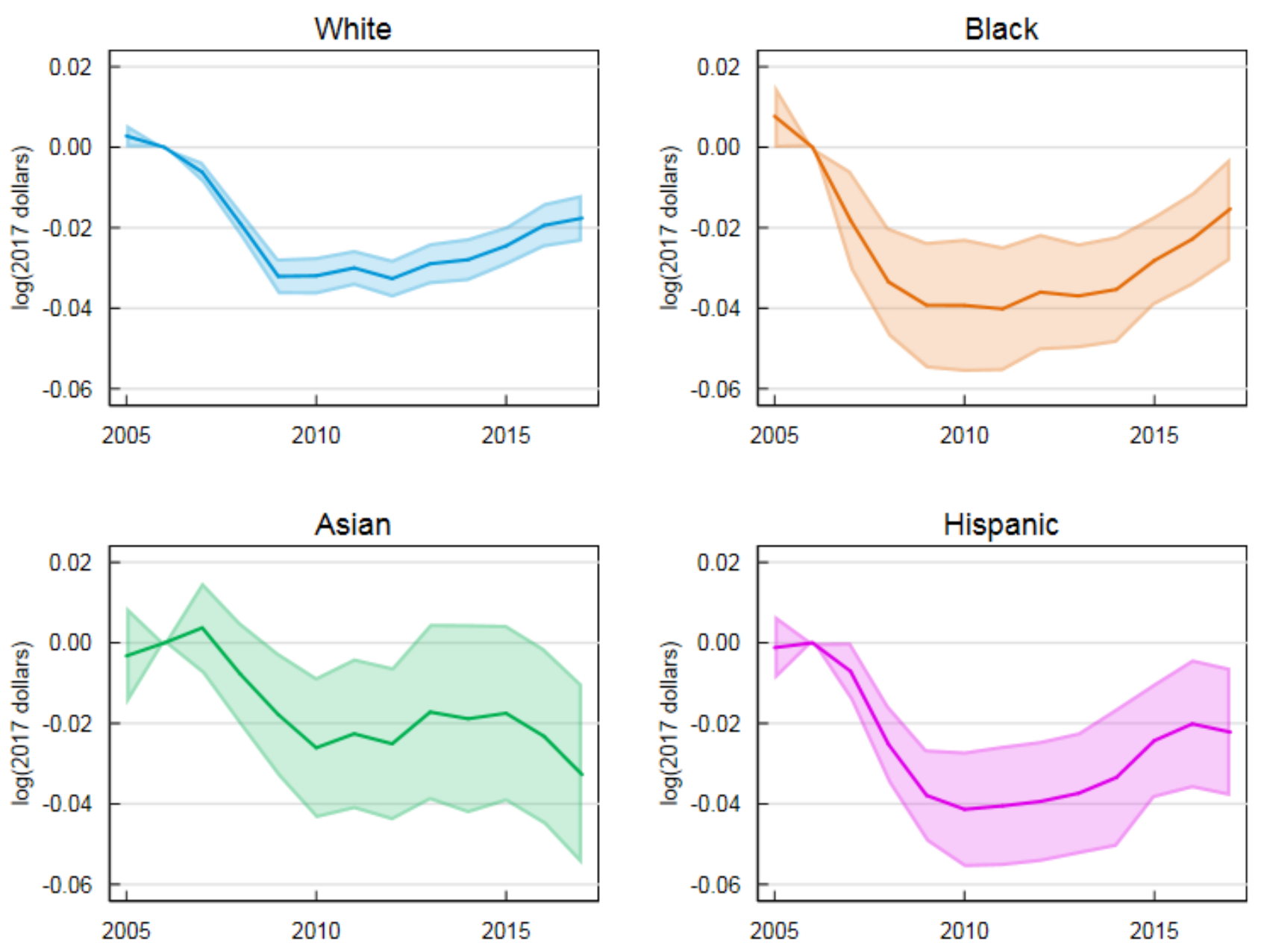

Source: Form 1040, Form 1099, Form W-2, Census Numident, American Community Survey (2001 through 2017), Decennial Census (2000 and 2010 ), MAF-ARF. Release authorization number CBDRB-FY19-376.

Note: Points plotted are $\beta$ coefficients as estimated in Equation 1. Shaded regions represent 95 percent confidence intervals. 
Figure B27: Person vs. Place Estimates, Log Earnings, 1928-1996 Birth Cohorts

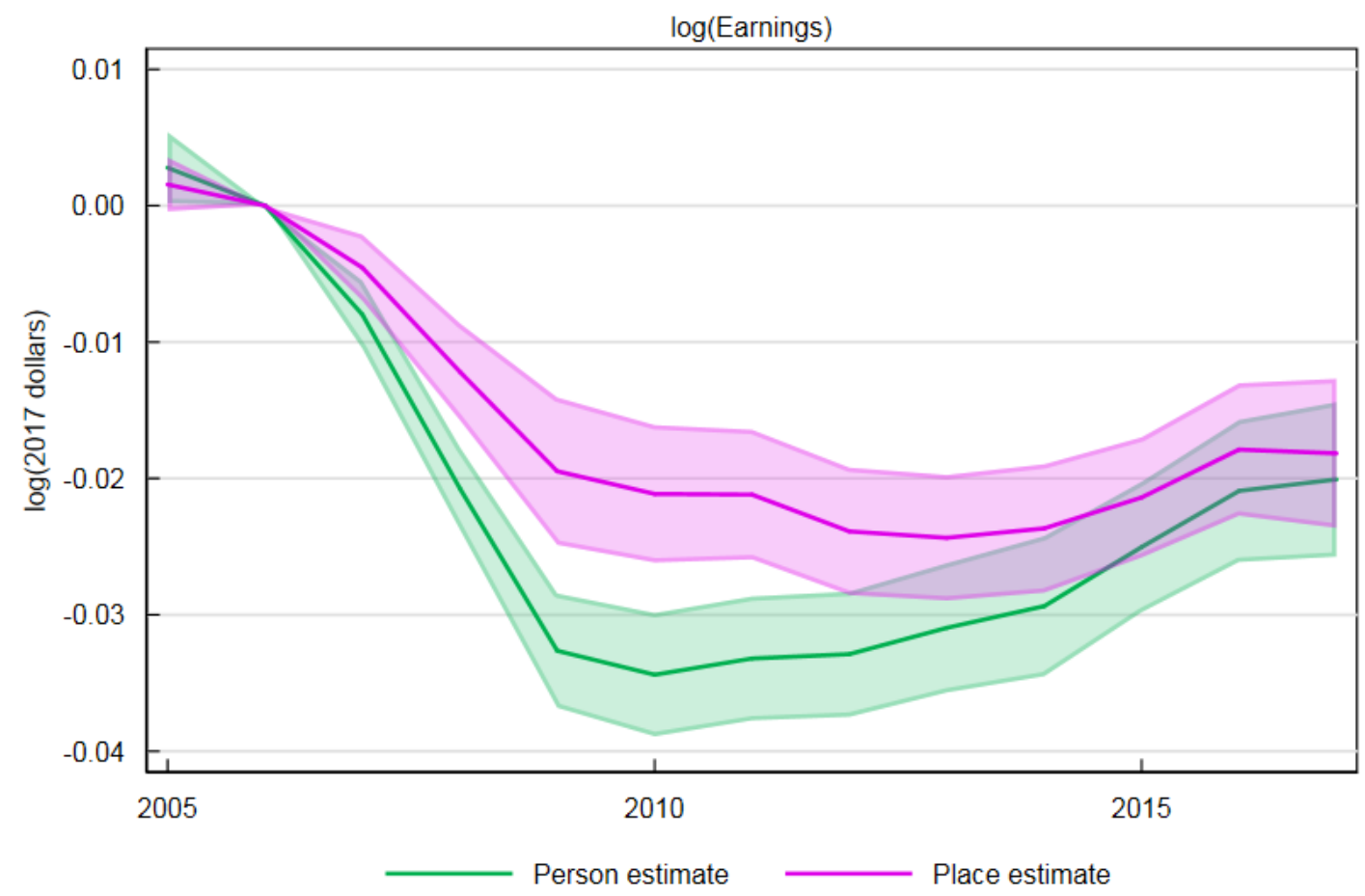

Source: Form 1040, Form 1099, Form W-2, Census Numident, American Community Survey (2001 through 2017), Decennial Census (2000 and 2010), MAF-ARF. Release authorization number CBDRB-FY19-376.

Note: Points plotted in green are $\beta$ coefficients as estimated in Equation[1 Points plotted in magenta are $\beta$ coefficients as estimated in Equation 3 Shaded regions represent 95 percent confidence intervals. 
Figure B28: Effects of Local Concentration Shocks on Log Earnings, 1928-1996 Birth Cohorts

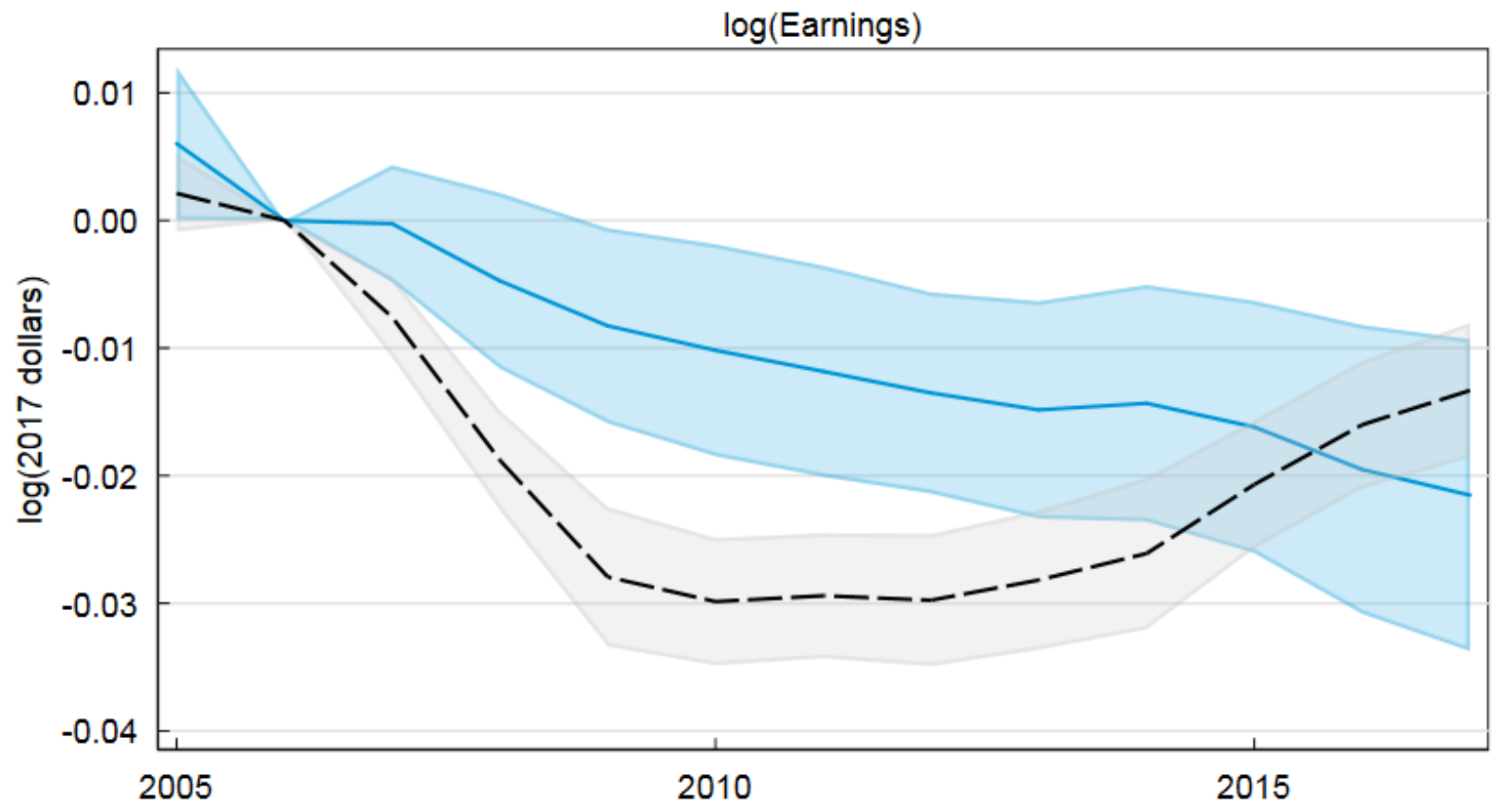

Source: Form 1040, Form 1099, Form W-2, Census Numident, American Community Survey (2001 through 2017), Decennial Census (2000 and 2010), MAF-ARF. Release authorization number CBDRB-FY19-500.

Note: Points plotted are $\beta$ coefficients as estimated in Equation 4 Shaded regions represent 95 percent confidence intervals. 
Figure B29: Effects of Local Concentration Shocks on Log Earnings, by Generation
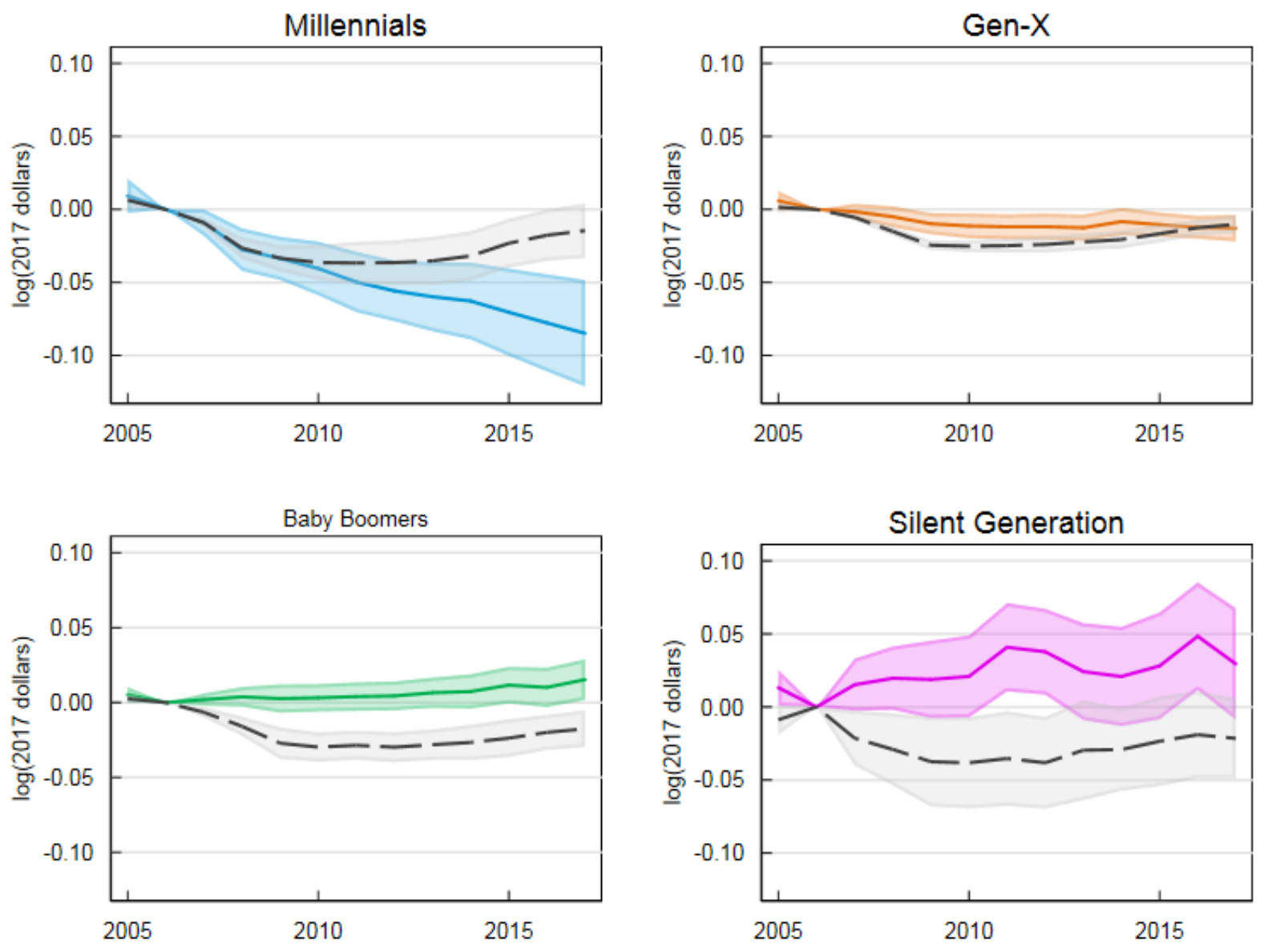

Source: Form 1040, Form 1099, Form W-2, Census Numident, American Community Survey (2001 through 2017), Decennial Census (2000 and 2010 ), MAF-ARF. Release authorization number CBDRB-FY19-500.

Note: Points plotted in solid blue are $\beta$ coefficients as estimated in Equation 4 . Dashed black lines are the effects of local unemployment shocks from this estimating equation (the $\zeta$ coefficients), for reference. Shaded regions represent 95 percent confidence intervals. 


\section{B.3 asinh(Earnings)}

Figure B30: Effects of Local Unemployment Shocks on asinh(Earnings), 1957-1976 Birth Cohorts

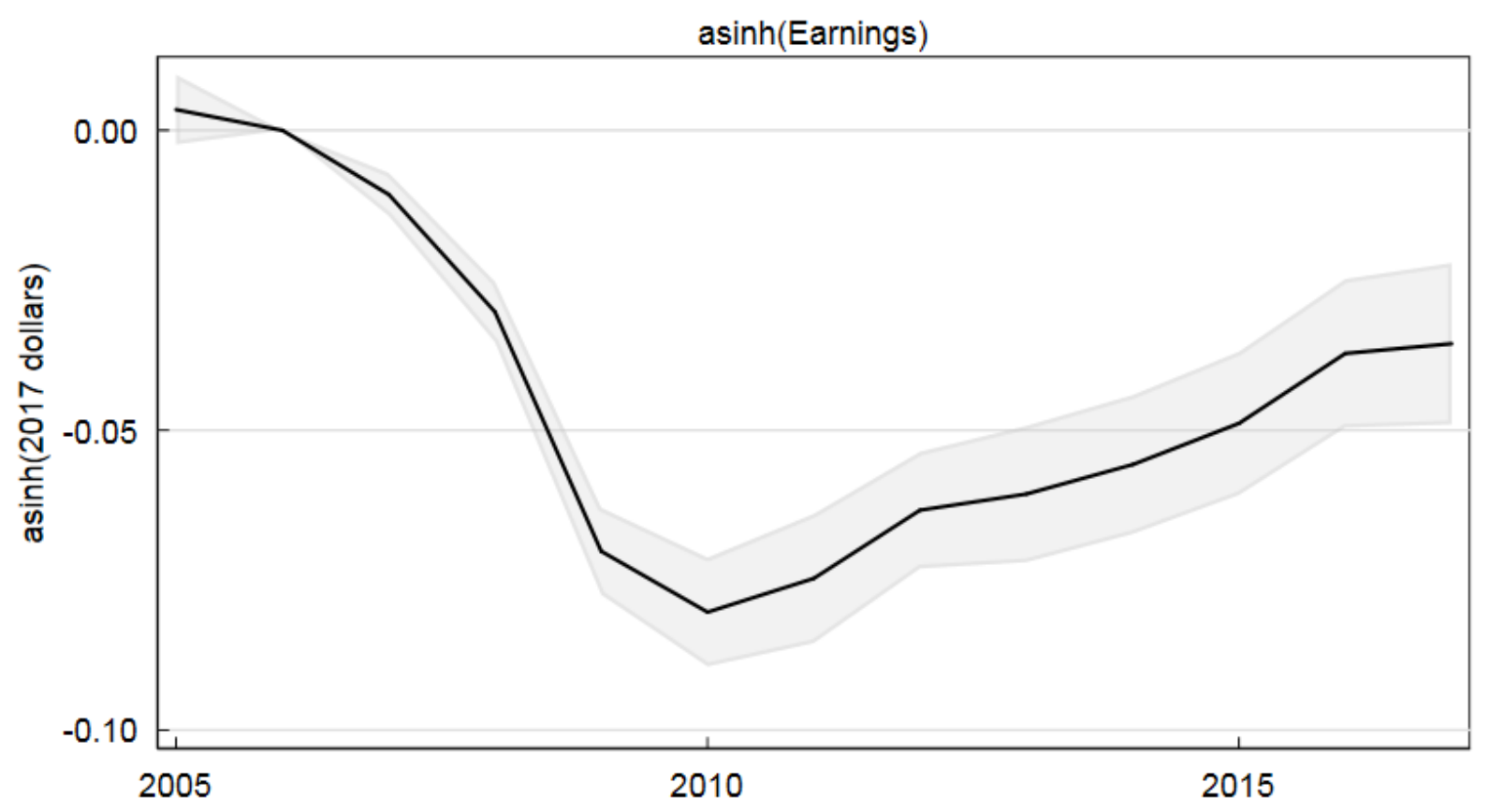

Source: Form 1040, Form 1099, Form W-2, Census Numident, American Community Survey (2001 through 2017), Decennial Census (2000 and 2010), MAF-ARF. Release authorization number CBDRB-FY19-376.

Note: Points plotted are $\beta$ coefficients as estimated in Equation 1 Shaded regions represent 95 percent confidence intervals. 
Figure B31: Effects of Local Unemployment Shocks on asinh(Earnings), 1928-1996 Birth Cohorts

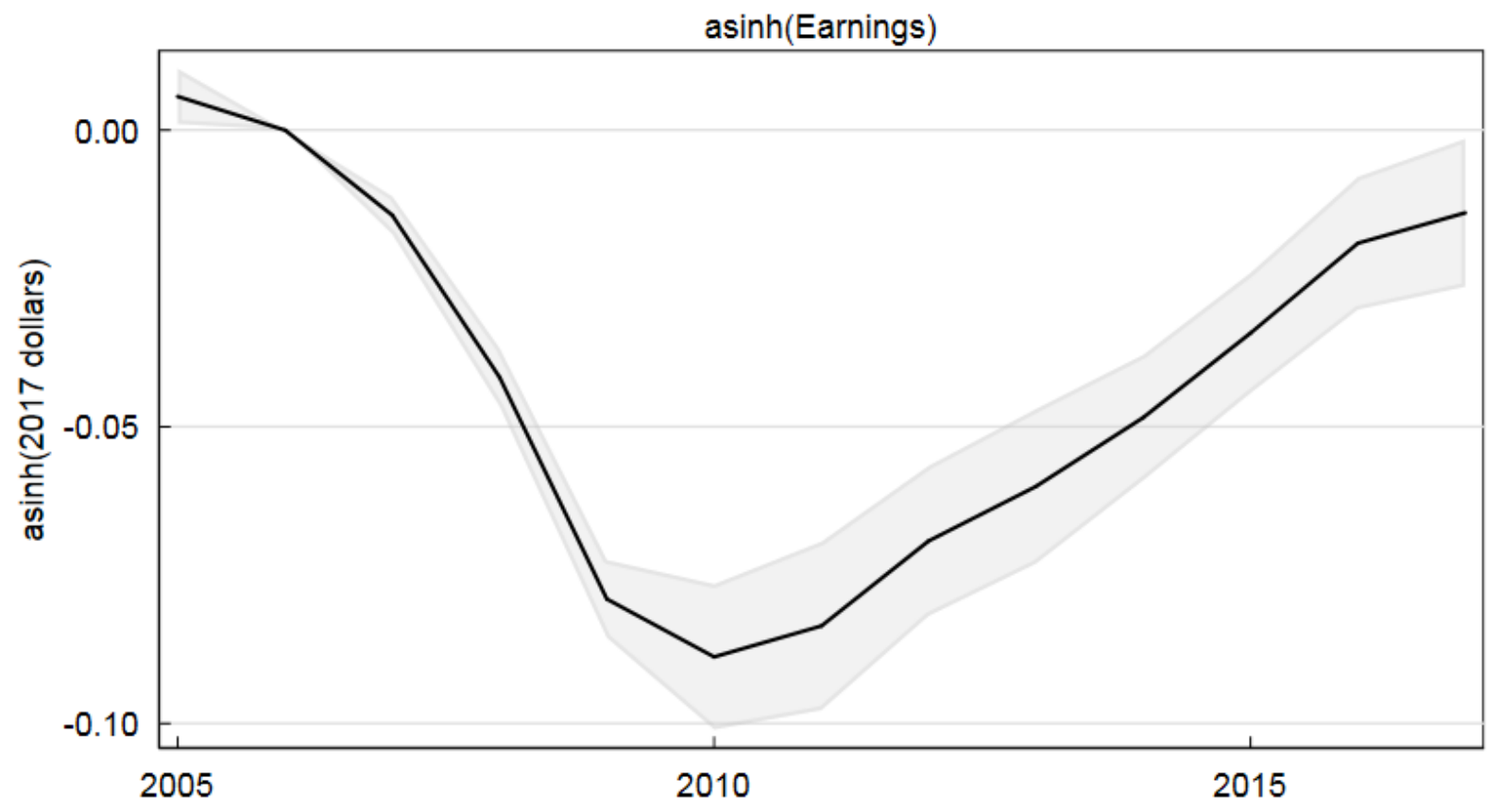

Source: Form 1040, Form 1099, Form W-2, Census Numident, American Community Survey (2001 through 2017), Decennial Census (2000 and 2010), MAF-ARF. Release authorization number CBDRB-FY19-376.

Note: Points plotted are $\beta$ coefficients as estimated in Equation 1 Shaded regions represent 95 percent confidence intervals. 
Figure B32: Effects of Local Unemployment Shocks on asinh(Earnings), by Generation
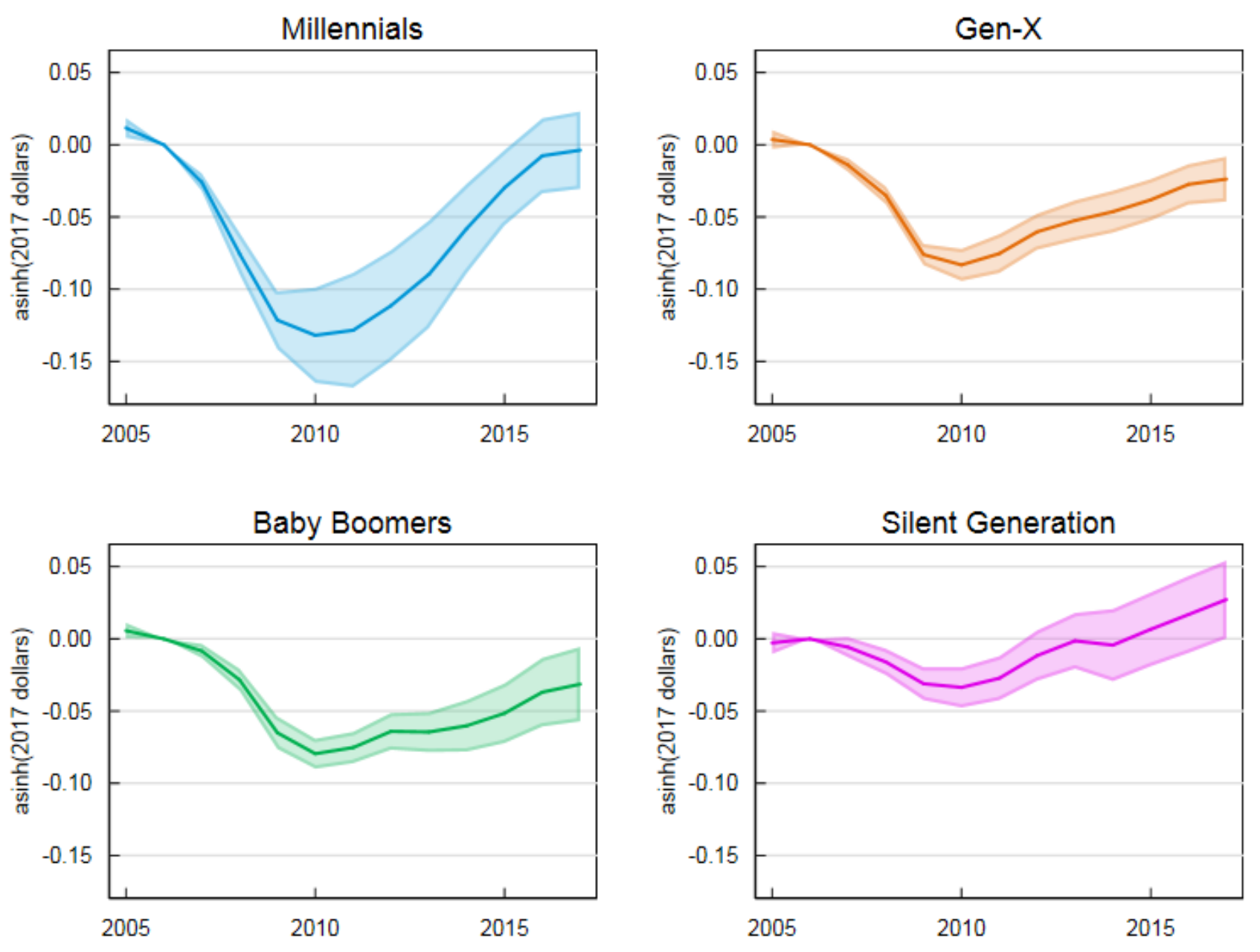

Source: Form 1040, Form 1099, Form W-2, Census Numident, American Community Survey (2001 through 2017), Decennial Census (2000 and 2010 ), MAF-ARF. Release authorization number CBDRB-FY19-376.

Note: Points plotted are $\beta$ coefficients as estimated in Equation 1. Shaded regions represent 95 percent confidence intervals. 
Figure B33: Effects of Local Unemployment Shocks on asinh(Earnings), by Displacement Status
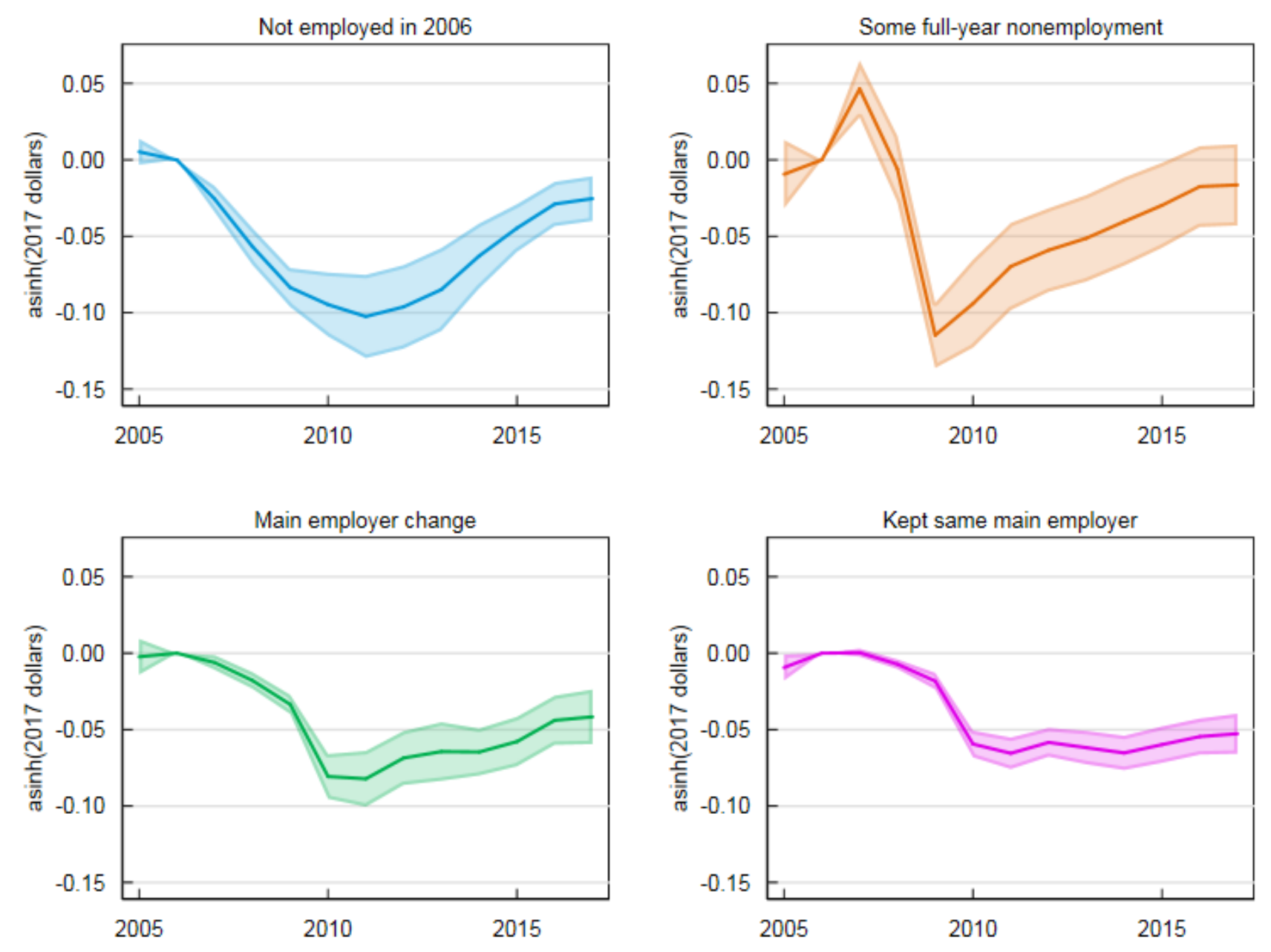

Source: Form 1040, Form 1099, Form W-2, Census Numident, American Community Survey (2001 through 2017), Decennial Census (2000 and 2010), MAF-ARF. Release authorization number CBDRB-FY19-376.

Note: Points plotted are $\beta$ coefficients as estimated in Equation 1. Shaded regions represent 95 percent confidence intervals. 
Figure B34: Effects of Local Unemployment Shocks on asinh(Earnings), by Gender

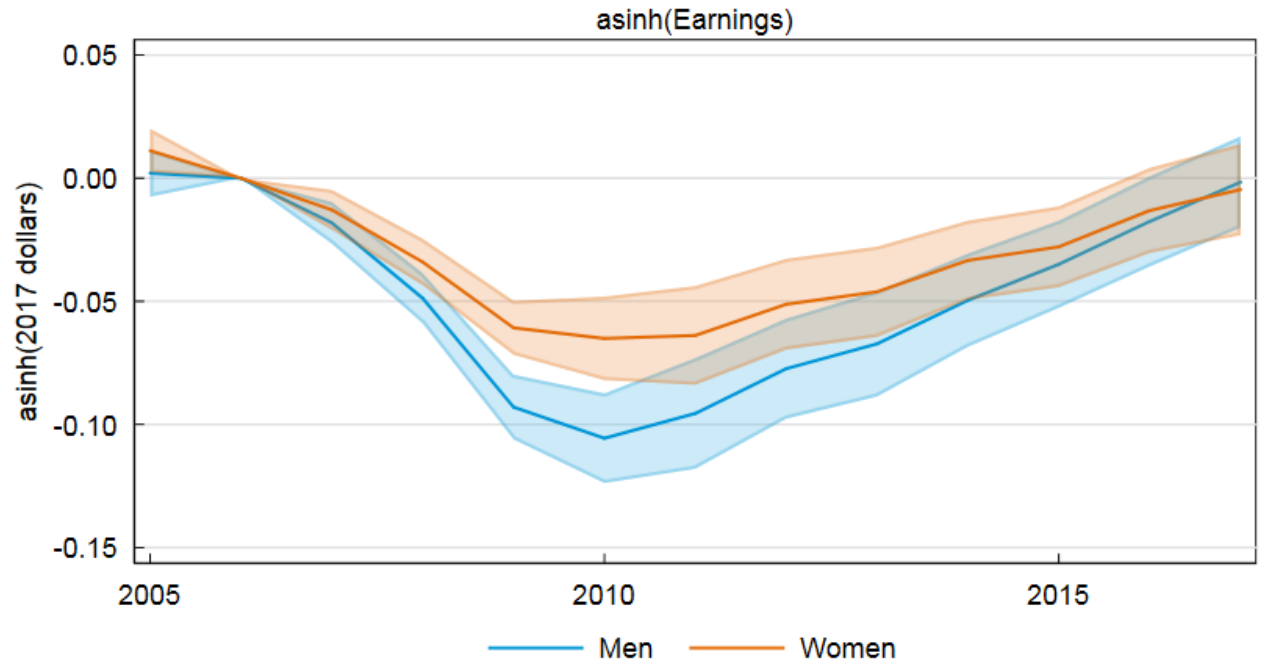

Source: Form 1040, Form 1099, Form W-2, Census Numident, American Community Survey (2001 through 2017), Decennial Census (2000 and 2010), MAF-ARF. Release authorization number CBDRB-FY19-376.

Note: Points plotted are $\beta$ coefficients as estimated in Equation 1 Shaded regions represent 95 percent confidence intervals. 
Figure B35: Effects of Local Unemployment Shocks on asinh(Earnings), by Gender and Generation
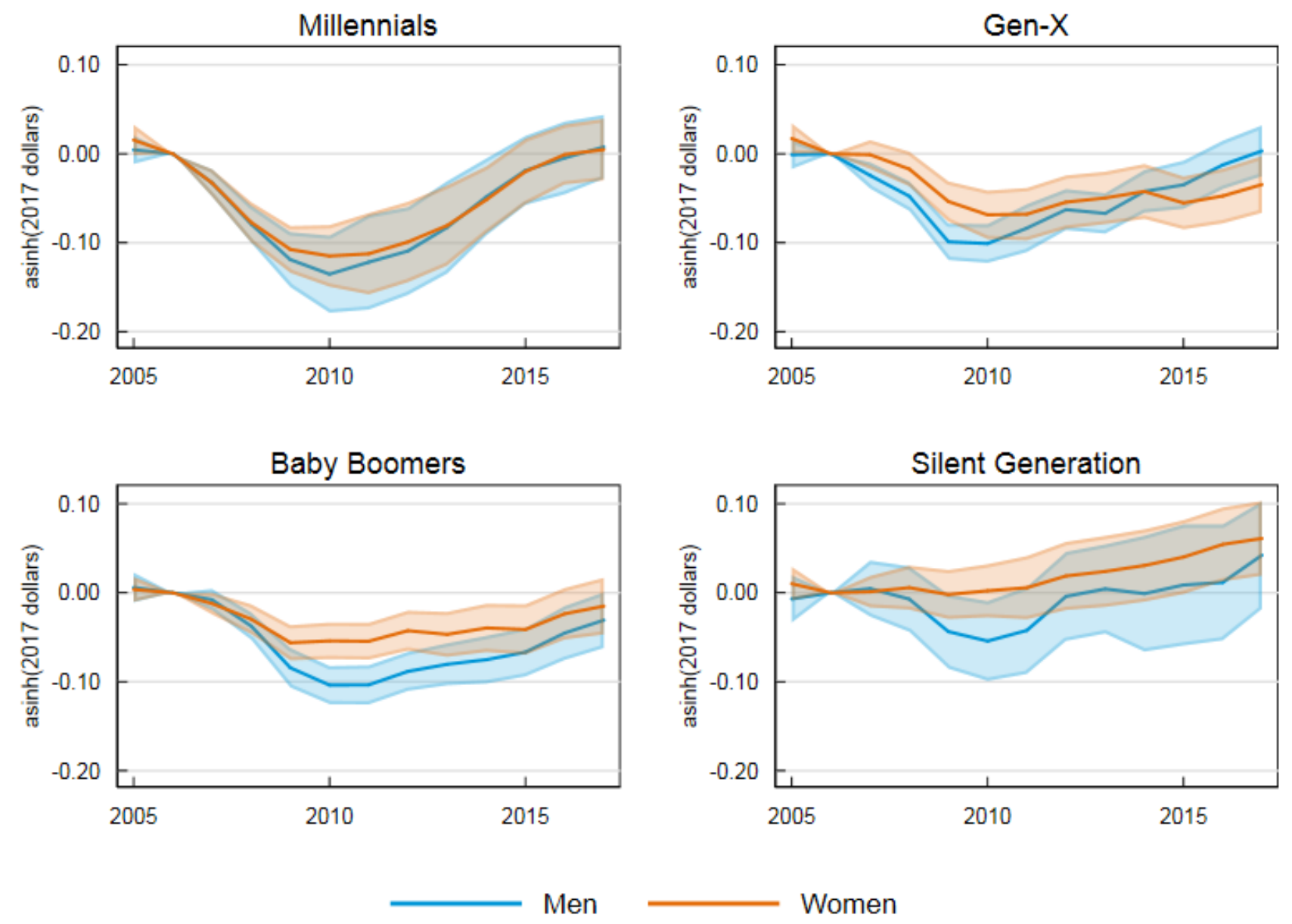

Source: Form 1040, Form 1099, Form W-2, Census Numident, American Community Survey (2001 through 2017), Decennial Census (2000 and 2010), MAF-ARF. Release authorization number CBDRB-FY19-376.

Note: Points plotted are $\beta$ coefficients as estimated in Equation 1. Shaded regions represent 95 percent confidence intervals. 
Figure B36: Effects of Local Unemployment Shocks on asinh(Earnings), by Race
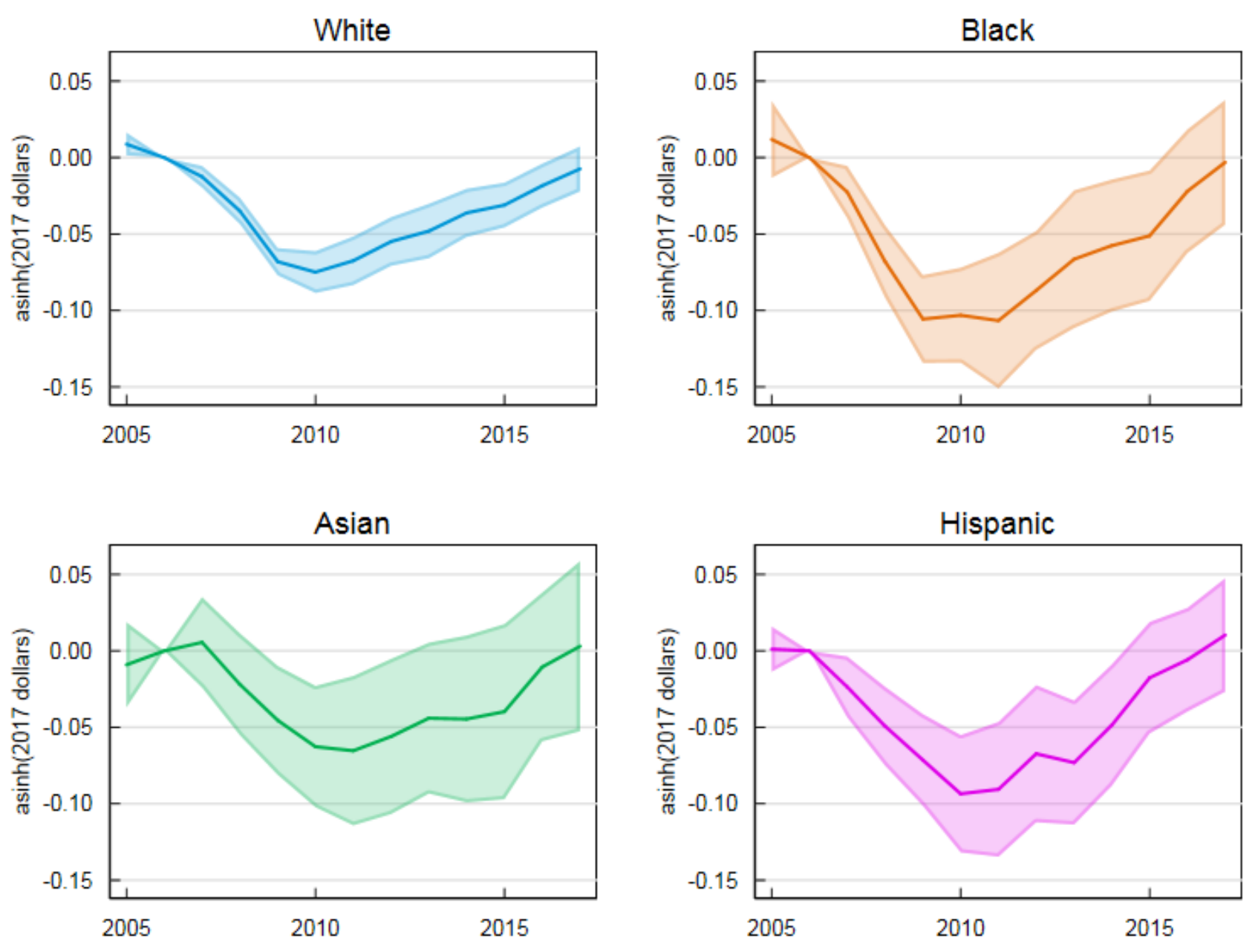

Source: Form 1040, Form 1099, Form W-2, Census Numident, American Community Survey (2001 through 2017), Decennial Census (2000 and 2010), MAF-ARF. Release authorization number CBDRB-FY19-376.

Note: Points plotted are $\beta$ coefficients as estimated in Equation 1. Shaded regions represent 95 percent confidence intervals. 
Figure B37: Person vs. Place Estimates, asinh(Earnings), 1928-1996 Birth Cohorts

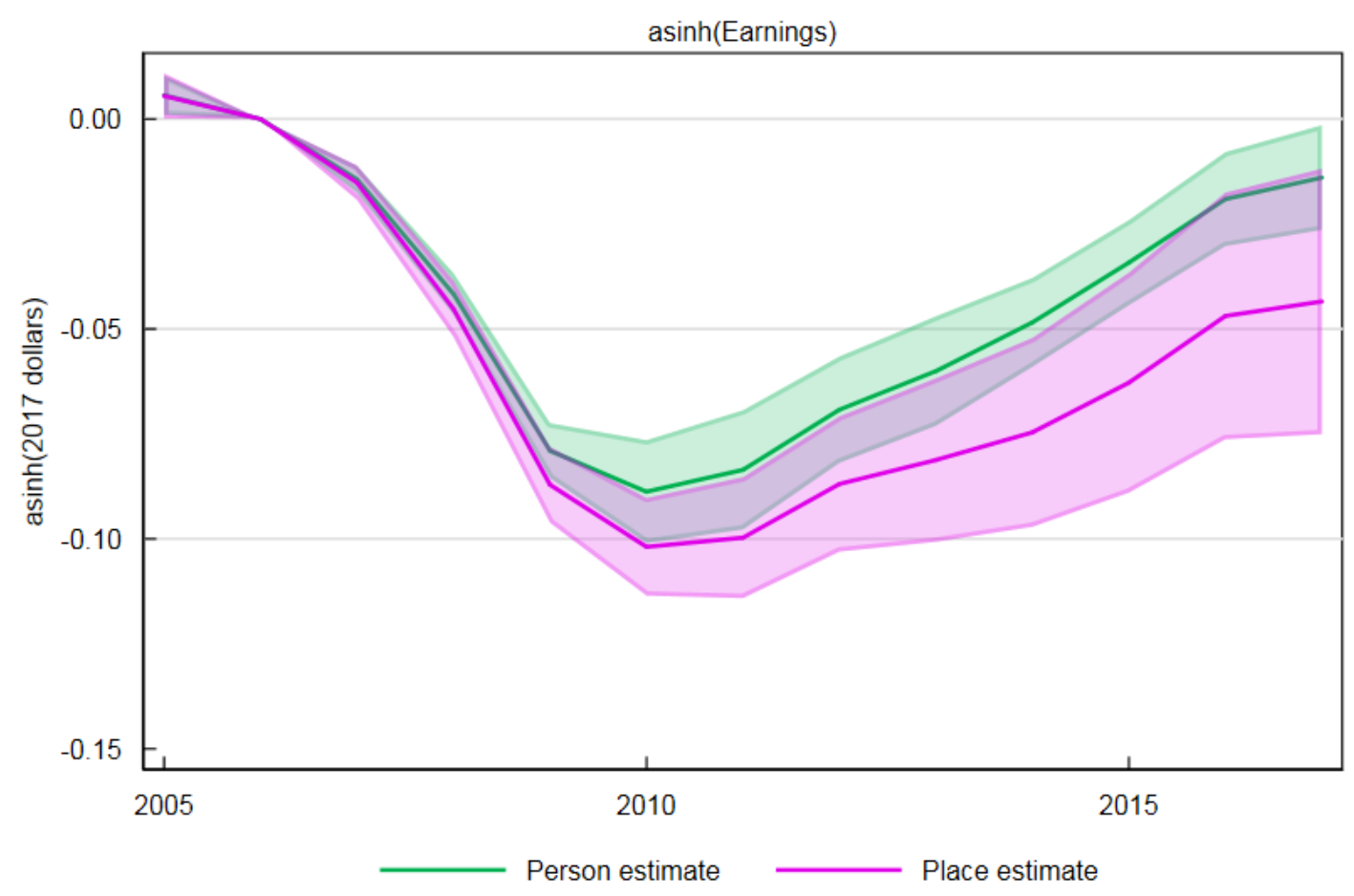

Source: Form 1040, Form 1099, Form W-2, Census Numident, American Community Survey (2001 through 2017), Decennial Census (2000 and 2010), MAF-ARF. Release authorization number CBDRB-FY19-376.

Note: Points plotted are $\beta$ coefficients as estimated in Equation 1 Shaded regions represent 95 percent confidence intervals. 
Figure B38: Effects of Local Concentration Shocks on asinh(Earnings), 1928-1996 Birth Cohorts

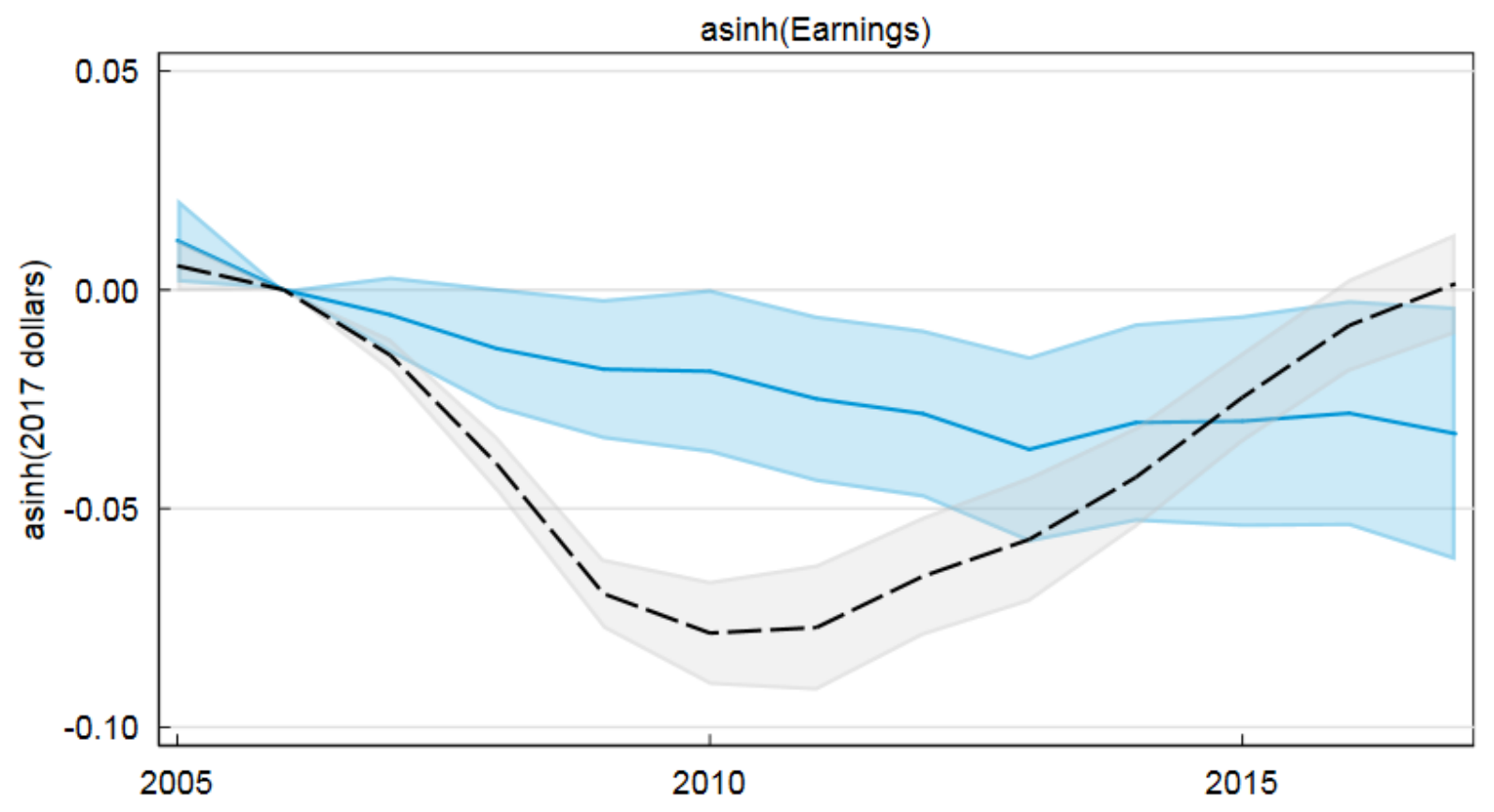

Source: Form 1040, Form 1099, Form W-2, Census Numident, American Community Survey (2001 through 2017), Decennial Census (2000 and 2010), MAF-ARF. Release authorization number CBDRB-FY19-500.

Note: Points plotted in solid blue are $\beta$ coefficients as estimated in Equation 4 . Dashed black lines are the effects of local unemployment shocks from this estimating equation (the $\zeta$ coefficients), for reference. Shaded regions represent 95 percent confidence intervals. 
Figure B39: Effects of Local Concentration Shocks on asinh(Earnings), by Generation
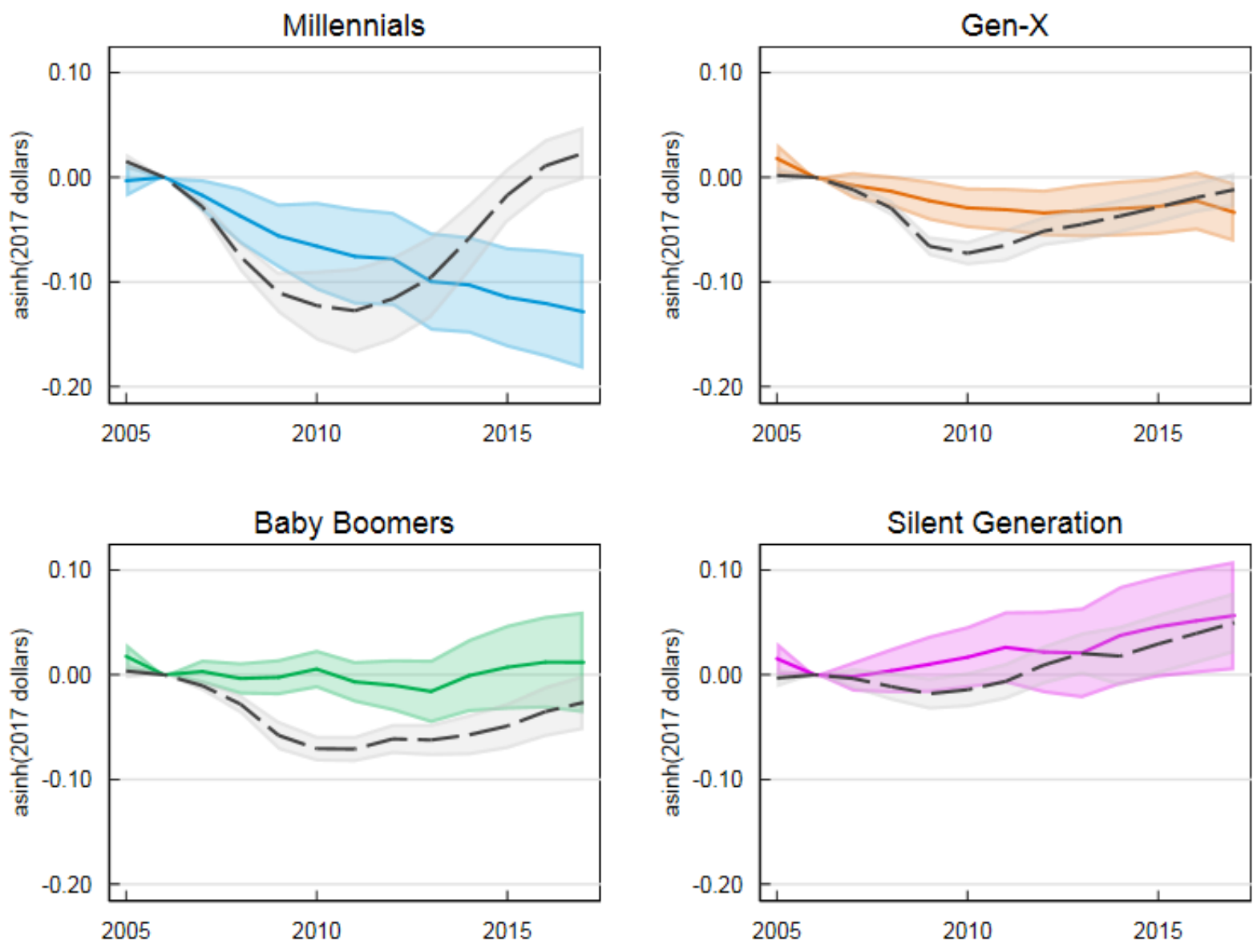

Source: Form 1040, Form 1099, Form W-2, Census Numident, American Community Survey (2001 through 2017), Decennial Census (2000 and 2010), MAF-ARF. Release authorization number CBDRB-FY19-500.

Note: Points plotted in solid blue are $\beta$ coefficients as estimated in Equation 4 . Dashed black lines are the effects of local unemployment shocks from this estimating equation (the $\zeta$ coefficients), for reference. Shaded regions represent 95 percent confidence intervals. 


\section{Appendix C Firm Quality}

\section{C.1 Estimation Procedure}

In order to measure firm quality, I use a procedure in the spirit of Abowd et al. (1999). I break the 2005-2017 period I consider into five sub-periods: pre-recession (2005-2006), recession (2007-2009), early recovery (2010-2012), middle recovery (2013-2015), and late recovery (2016-2017). Within each of those sub-periods, I then use the full set of W-2 data from which my sample is drawn to estimate regressions of earnings of person and firm fixed effects (technically, EIN fixed effects). I retain the firm fixed effects from these regressions and rank firms on them within sub-period. I then average these rankings within firms across sub-periods. Finally, I rank firms according to their average sub-period ranking. I use this final ranking to identify high-paying firms.

In the baseline analysis, firms in the top quartile of mean sub-period firm fixed effect ranking are considered high-paying. Other formulations, presented below, consider the top decile or top half of this ranking to be high-paying firms, or use the ranking itself as the outcome. When the ranking is used as the dependent variable, I produce estimates that use it directly, excluding employeeyears of firms that could not have a fixed effect estimated, as well as estimates that incorporate those observations by assigning either zero or the mean ranking to firms that could not be ranked. All formulations of this firm quality analysis tell a similar story: younger workers' likelihood of working at high-paying firms has been more persistently negatively affected by exposure to local unemployment shocks than has older workers'.

\section{C.2 Additional Estimates}


Figure C1: Effects of Local Unemployment Shocks on Probability of Working for a High-Paying Employer (Above Median), by Generation
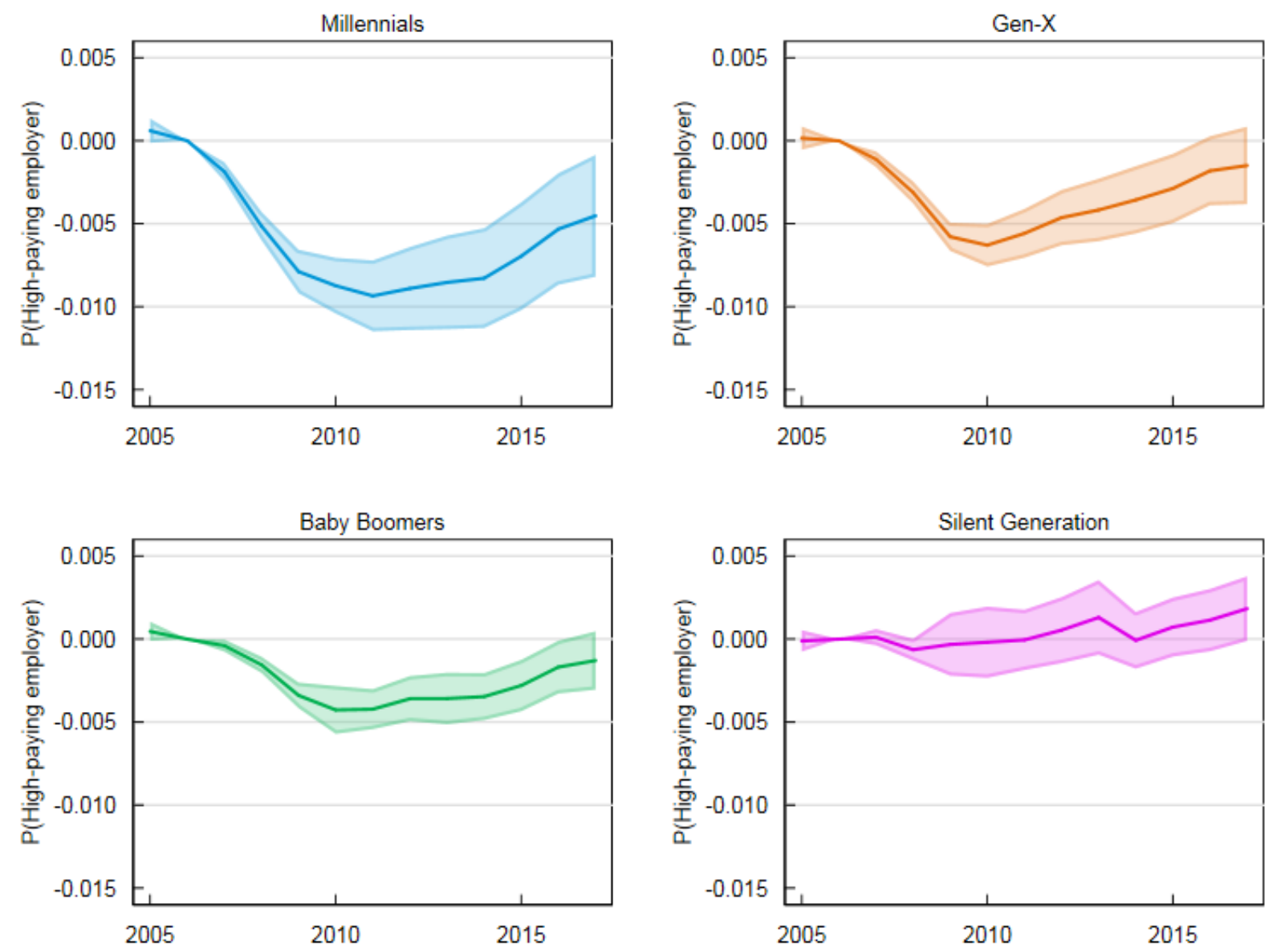

Source: Form 1040, Form 1099, Form W-2, Census Numident, American Community Survey (2001 through 2017), Decennial Census (2000 and 2010), MAF-ARF. Release authorization number CBDRB-FY19-500.

Note: Points plotted are $\beta$ coefficients as estimated in Equation 1. Shaded regions represent 95 percent confidence intervals. 
Figure C2: Effects of Local Unemployment Shocks on Probability of Working for a High-Paying Employer (Top Decile), by Generation
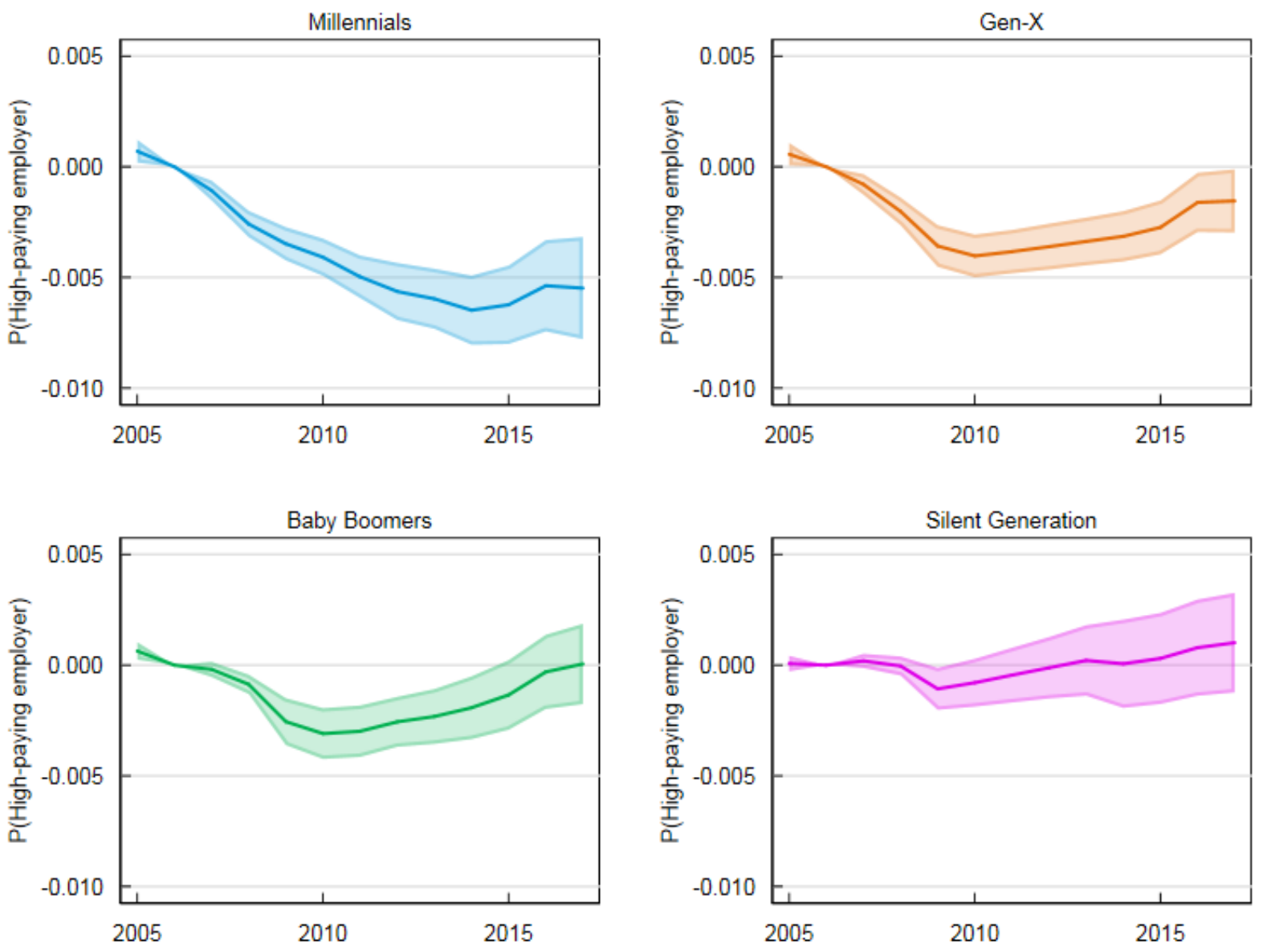

Source: Form 1040, Form 1099, Form W-2, Census Numident, American Community Survey (2001 through 2017), Decennial Census (2000 and 2010), MAF-ARF. Release authorization number CBDRB-FY19-500.

Note: Points plotted are $\beta$ coefficients as estimated in Equation 1. Shaded regions represent 95 percent confidence intervals. 
Figure C3: Effects of Local Unemployment Shocks on Employer Quality (Employer Pay Percentile, No Adjustment), by Generation
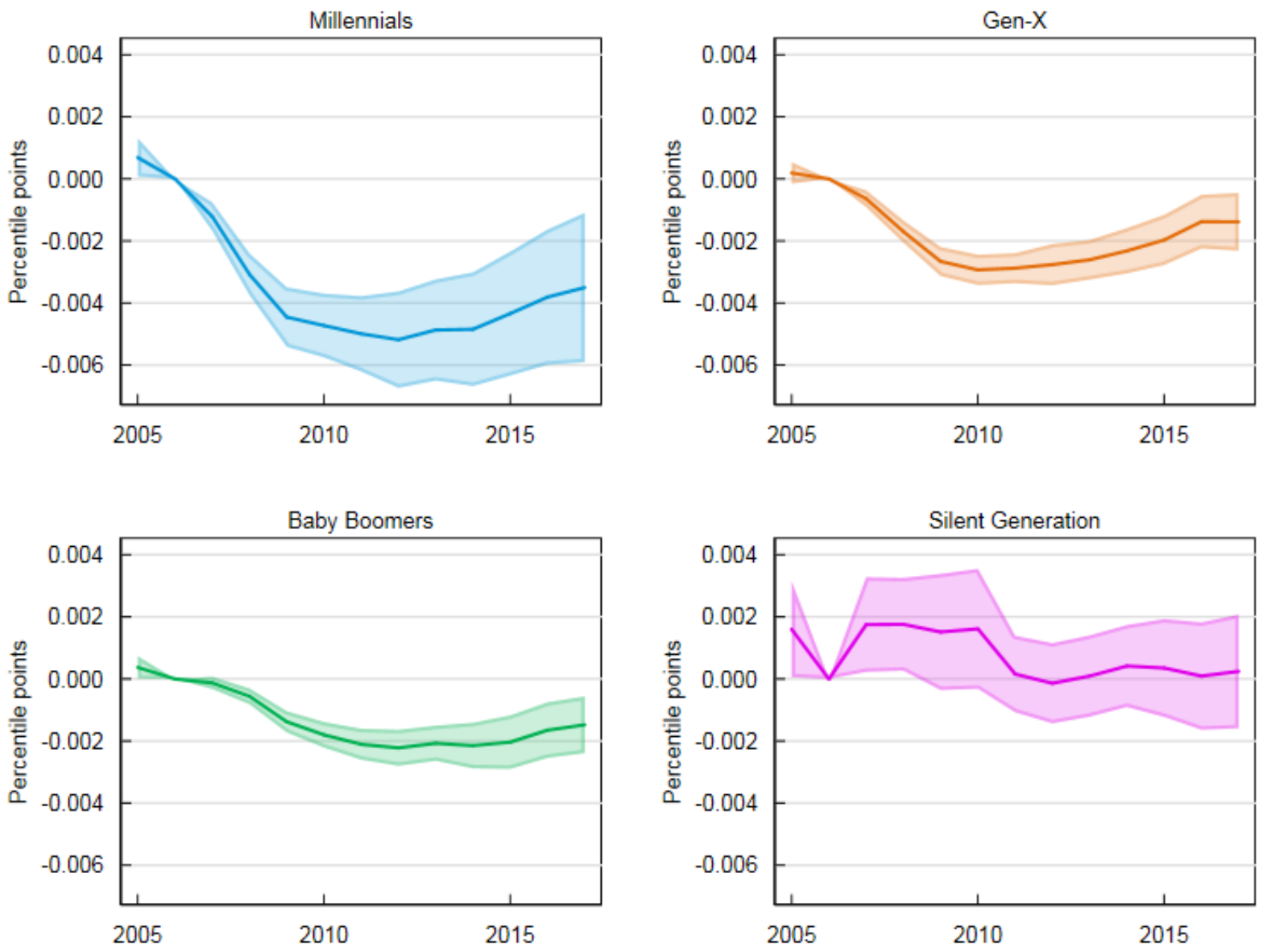

Source: Form 1040, Form 1099, Form W-2, Census Numident, American Community Survey (2001 through 2017), Decennial Census (2000 and 2010), MAF-ARF. Release authorization number CBDRB-FY19-500.

Note: Points plotted are $\beta$ coefficients as estimated in Equation 1. Shaded regions represent 95 percent confidence intervals. 
Figure C4: Effects of Local Unemployment Shocks on Employer Quality (Employer Pay Percentile, No Estimate = 0), by Generation
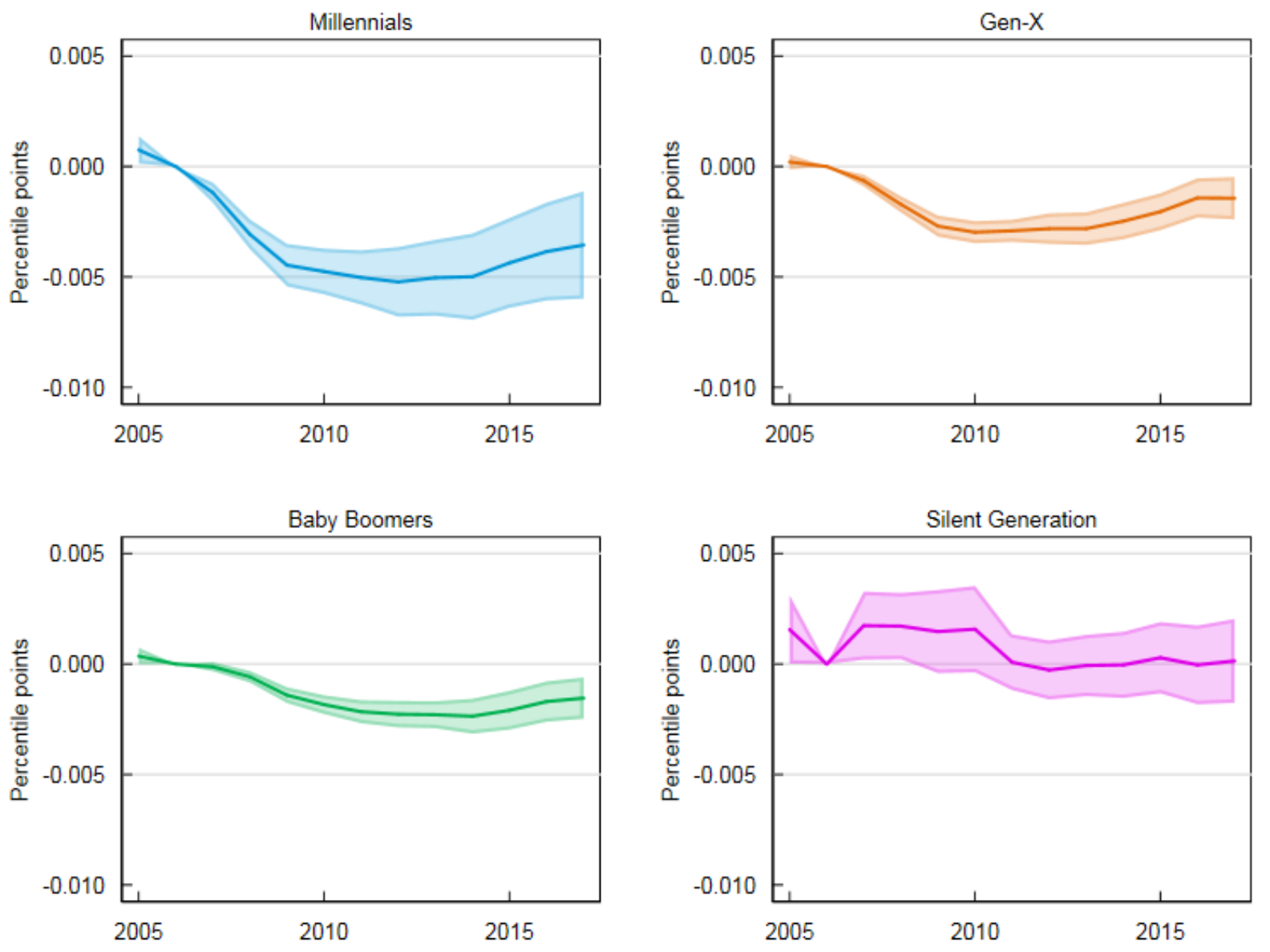

Source: Form 1040, Form 1099, Form W-2, Census Numident, American Community Survey (2001 through 2017), Decennial Census (2000 and 2010), MAF-ARF. Release authorization number CBDRB-FY19-500.

Note: Points plotted are $\beta$ coefficients as estimated in Equation 1. Shaded regions represent 95 percent confidence intervals. 
Figure C5: Effects of Local Unemployment Shocks on Employer Quality (Employer Pay Percentile, No Estimate = Mean), by Generation
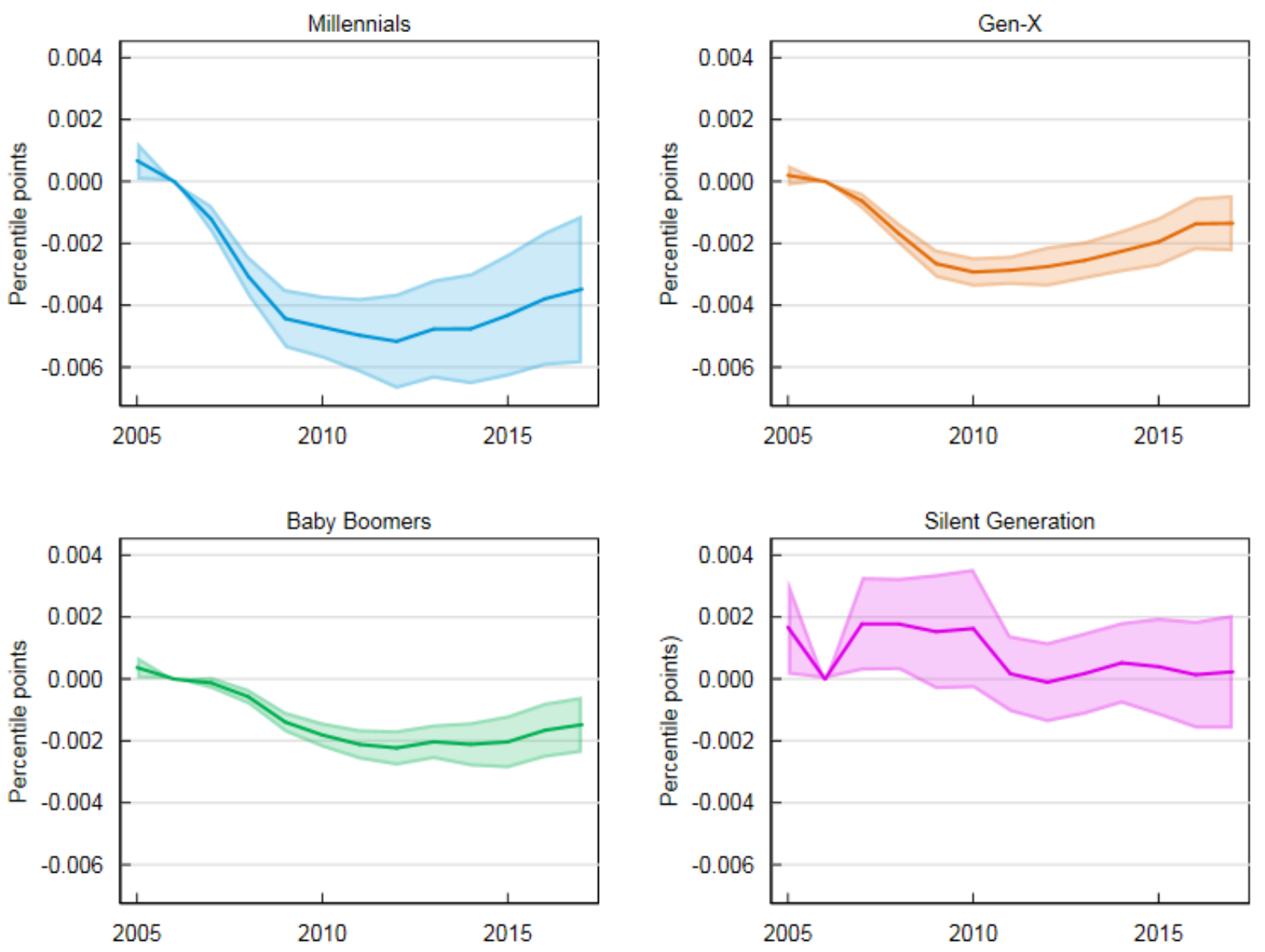

Source: Form 1040, Form 1099, Form W-2, Census Numident, American Community Survey (2001 through 2017), Decennial Census (2000 and 2010), MAF-ARF. Release authorization number CBDRB-FY19-500.

Note: Points plotted are $\beta$ coefficients as estimated in Equation 1. Shaded regions represent 95 percent confidence intervals. 
Figure C6: Effects of Local Unemployment Shocks on Employer Quality All MEasures, Full Sample
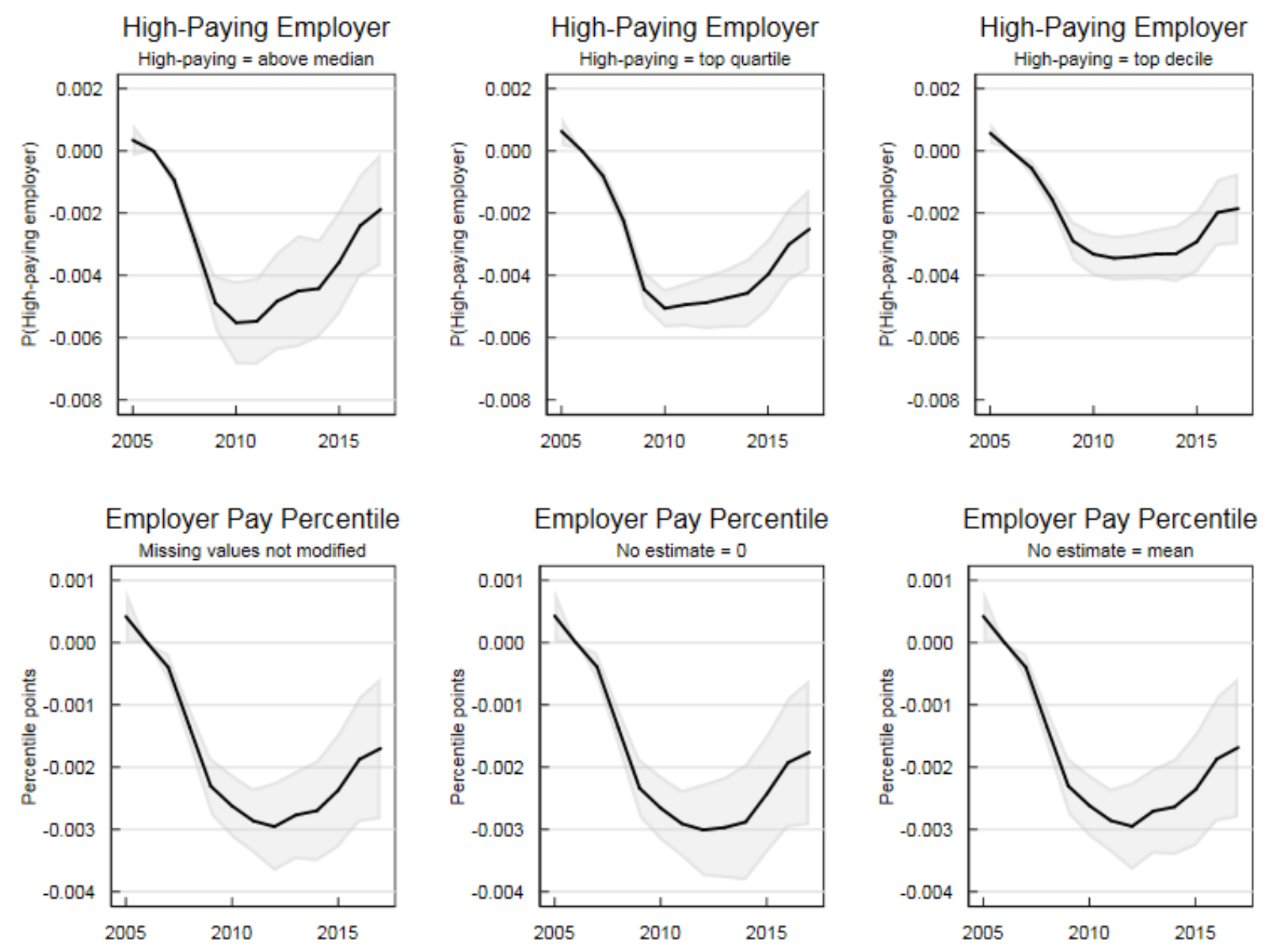

Source: Form 1040, Form 1099, Form W-2, Census Numident, American Community Survey (2001 through 2017), Decennial Census (2000 and 2010), MAF-ARF. Release authorization number CBDRB-FY19-500.

Note: Points plotted are $\beta$ coefficients as estimated in Equation 1. Shaded regions represent 95 percent confidence intervals. 


\section{Appendix D Displacement Status Estimates by Generation}

Figure D1: Effects of Local Unemployment Shocks on Earnings, by Displacement Status, Millennials
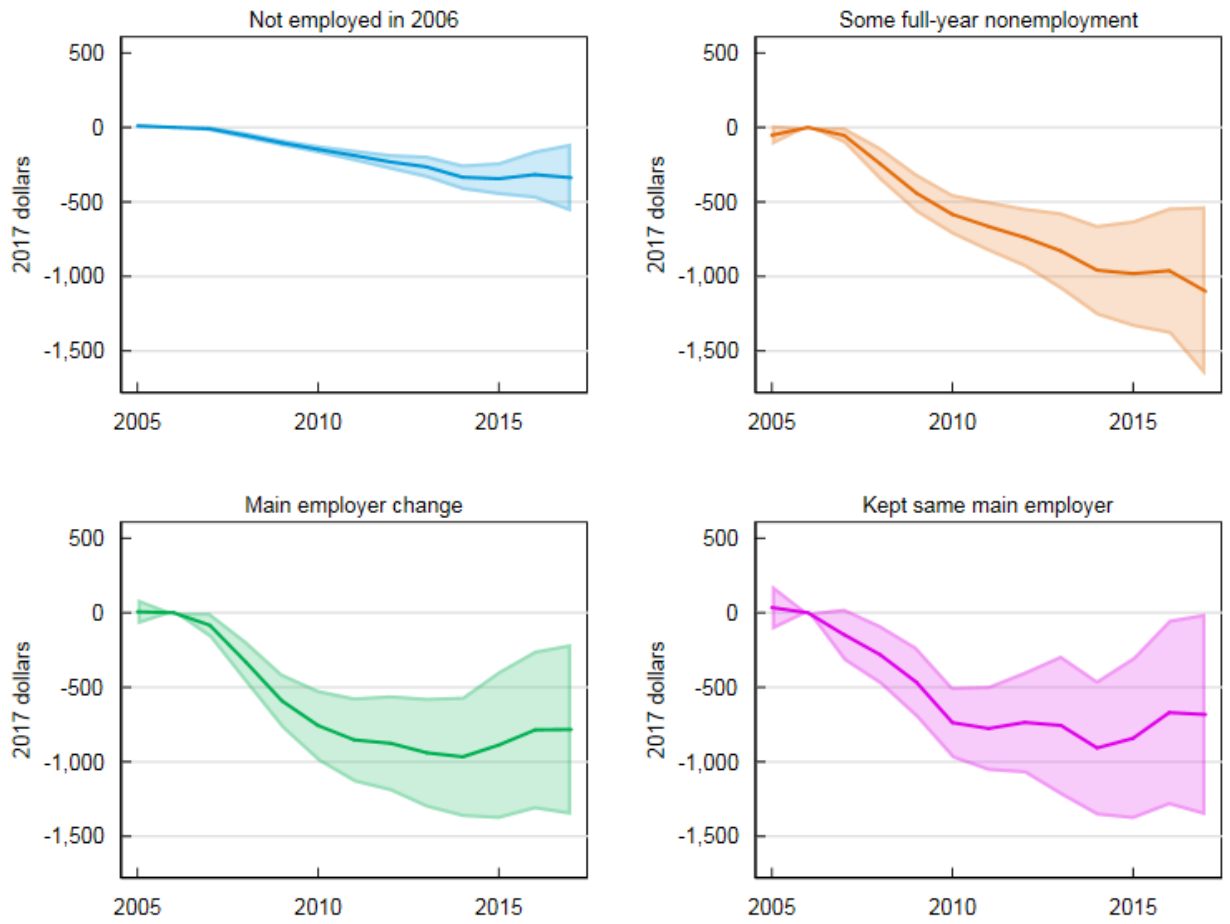

Source: Form 1040, Form 1099, Form W-2, Census Numident, American Community Survey (2001 through 2017), Decennial Census (2000 and 2010), MAF-ARF. Release authorization number CBDRB-FY19-431.

Note: Points plotted are $\beta$ coefficients as estimated in Equation 1. Shaded regions represent 95 percent confidence intervals. 
Figure D2: Effects of Local Unemployment Shocks on Earnings, by Displacement Status, Generation X
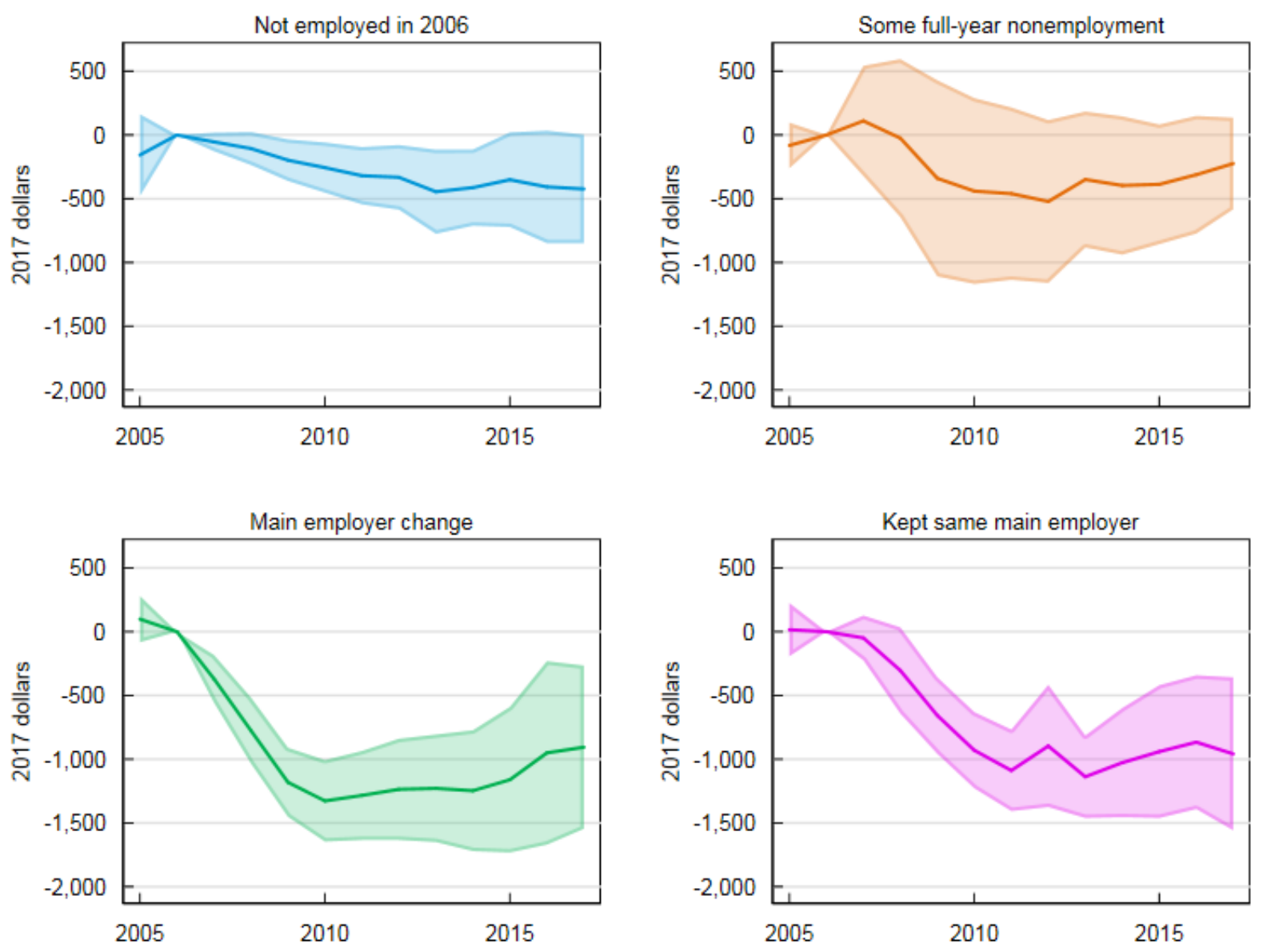

Source: Form 1040, Form 1099, Form W-2, Census Numident, American Community Survey (2001 through 2017), Decennial Census (2000 and 2010), MAF-ARF. Release authorization number CBDRB-FY19-431.

Note: Points plotted are $\beta$ coefficients as estimated in Equation 1. Shaded regions represent 95 percent confidence intervals. 
Figure D3: Effects of Local Unemployment Shocks on Earnings, by Displacement Status, Baby Boomers
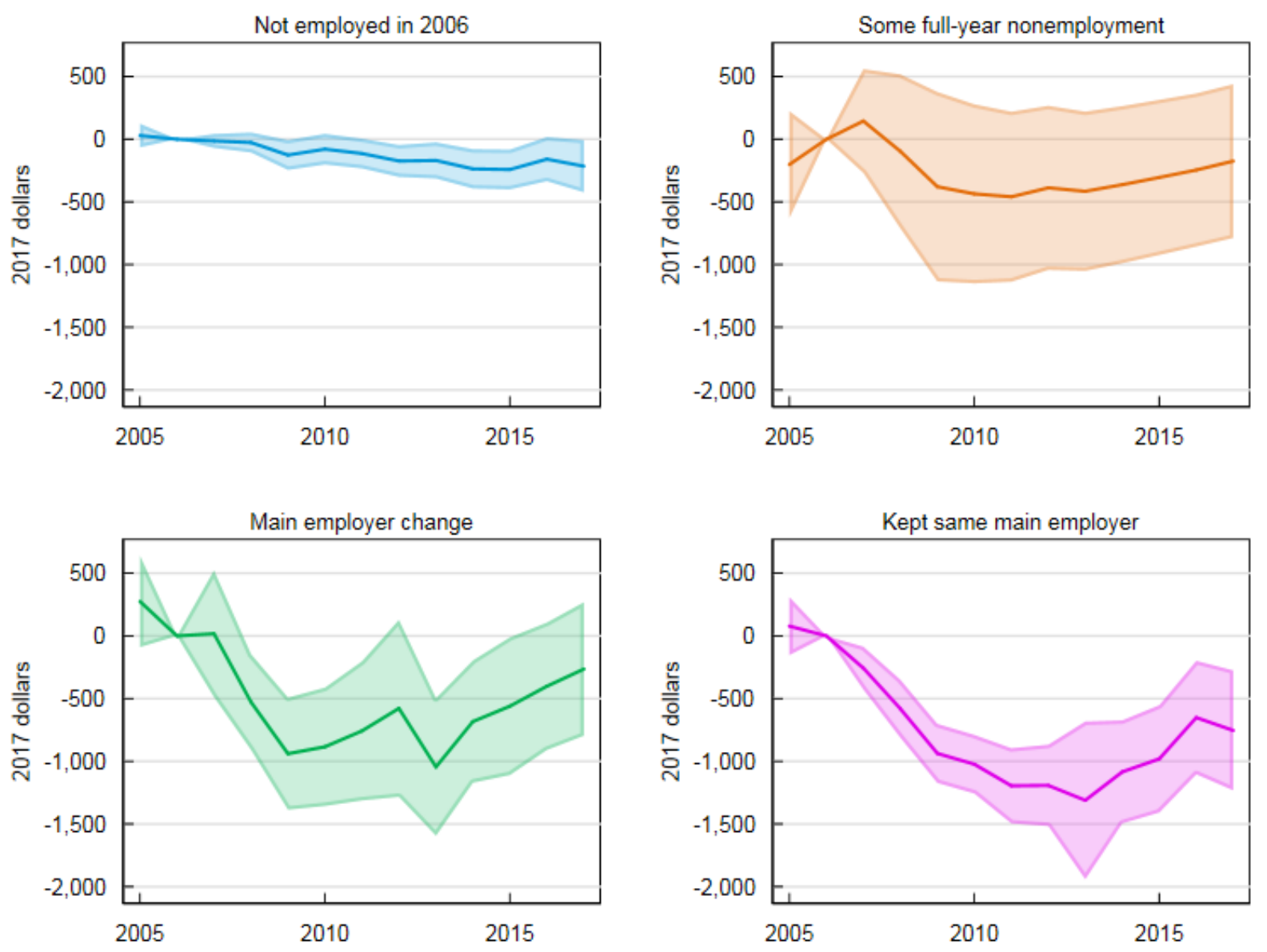

Source: Form 1040, Form 1099, Form W-2, Census Numident, American Community Survey (2001 through 2017), Decennial Census (2000 and 2010), MAF-ARF. Release authorization number CBDRB-FY19-431.

Note: Points plotted are $\beta$ coefficients as estimated in Equation 1. Shaded regions represent 95 percent confidence intervals. 
Figure D4: Effects of Local Unemployment Shocks on Earnings, by Displacement Status, Silent Generation
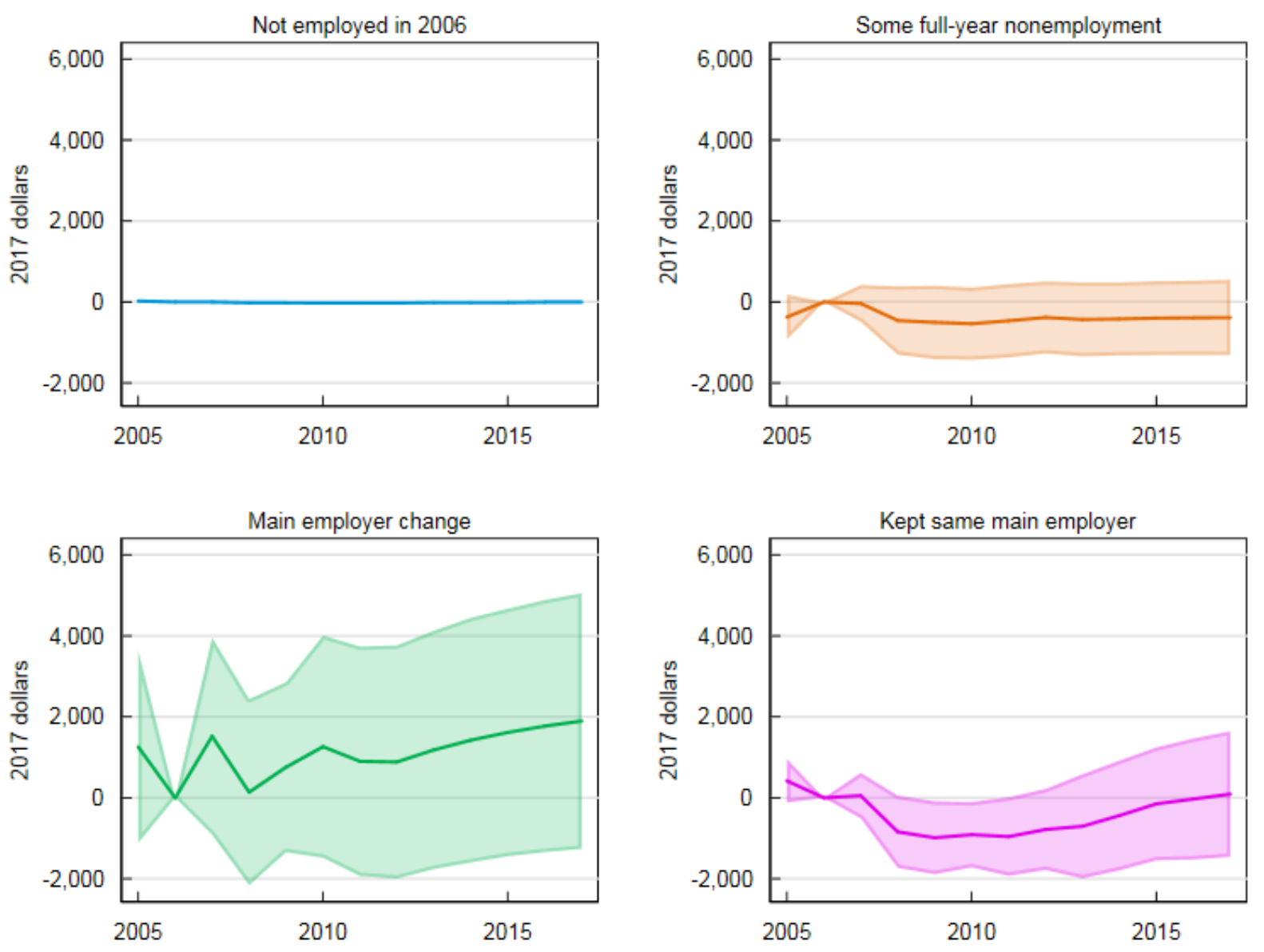

Source: Form 1040, Form 1099, Form W-2, Census Numident, American Community Survey (2001 through 2017), Decennial Census (2000 and 2010), MAF-ARF. Release authorization number CBDRB-FY19-431.

Note: Points plotted are $\beta$ coefficients as estimated in Equation 1. Shaded regions represent 95 percent confidence intervals. 
Figure D5: Effects of Local Unemployment Shocks on Earnings, by Displacement Status, Coefficient as Share of Mean Earnings
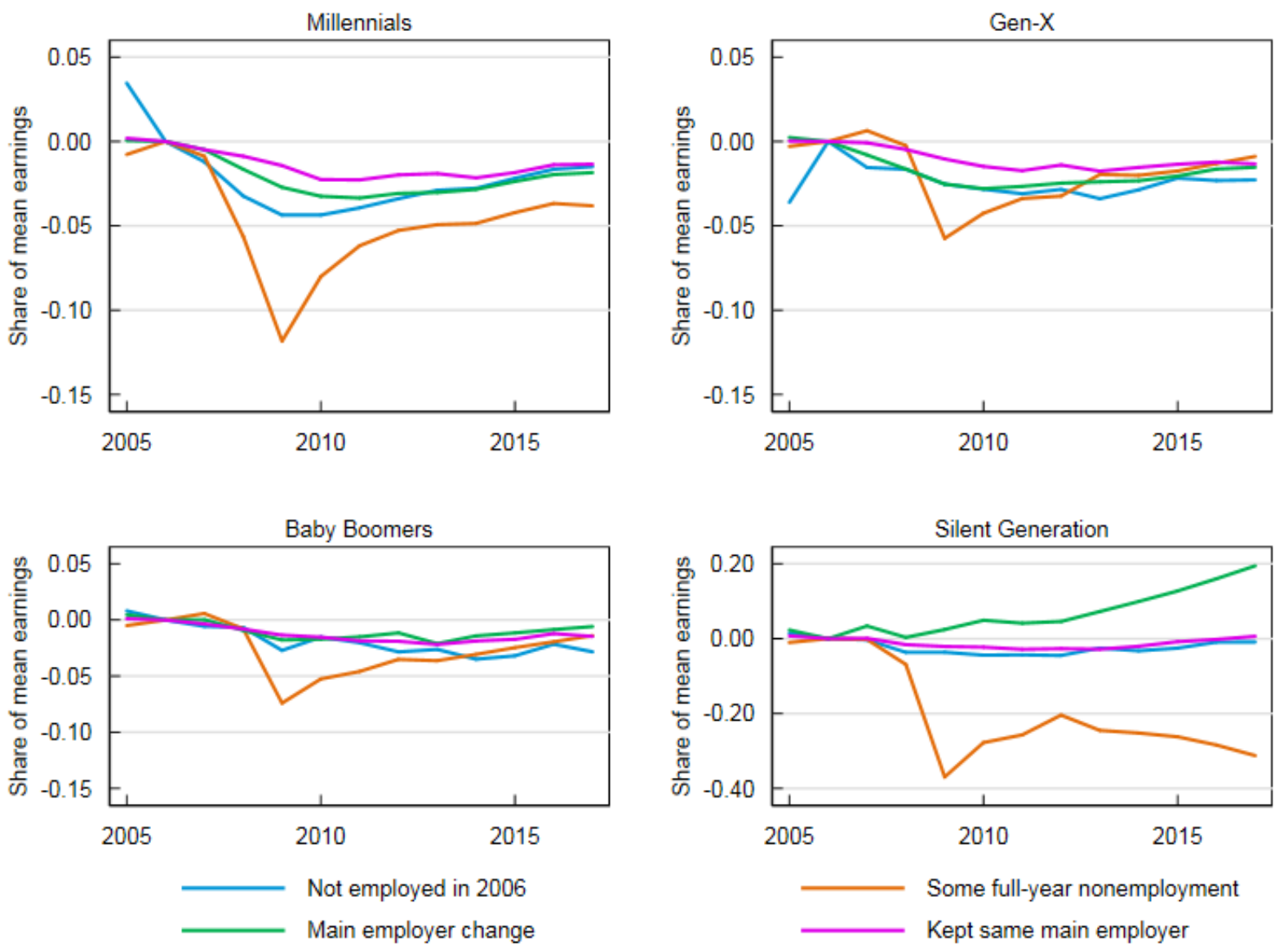

Source: Form 1040, Form 1099, Form W-2, Census Numident, American Community Survey (2001 through 2017), Decennial Census (2000 and 2010), MAF-ARF. Release authorization number CBDRB-FY19-431.

Note: Points plotted are $\beta$ coefficients as estimated in Equation 1 , divided by the mean of the corresponding outcome for the relevant group and year. 
Figure D6: Effects of Local Unemployment Shocks on Earnings, by Displacement Status, Effect of Average Shock as Share of Mean Earnings
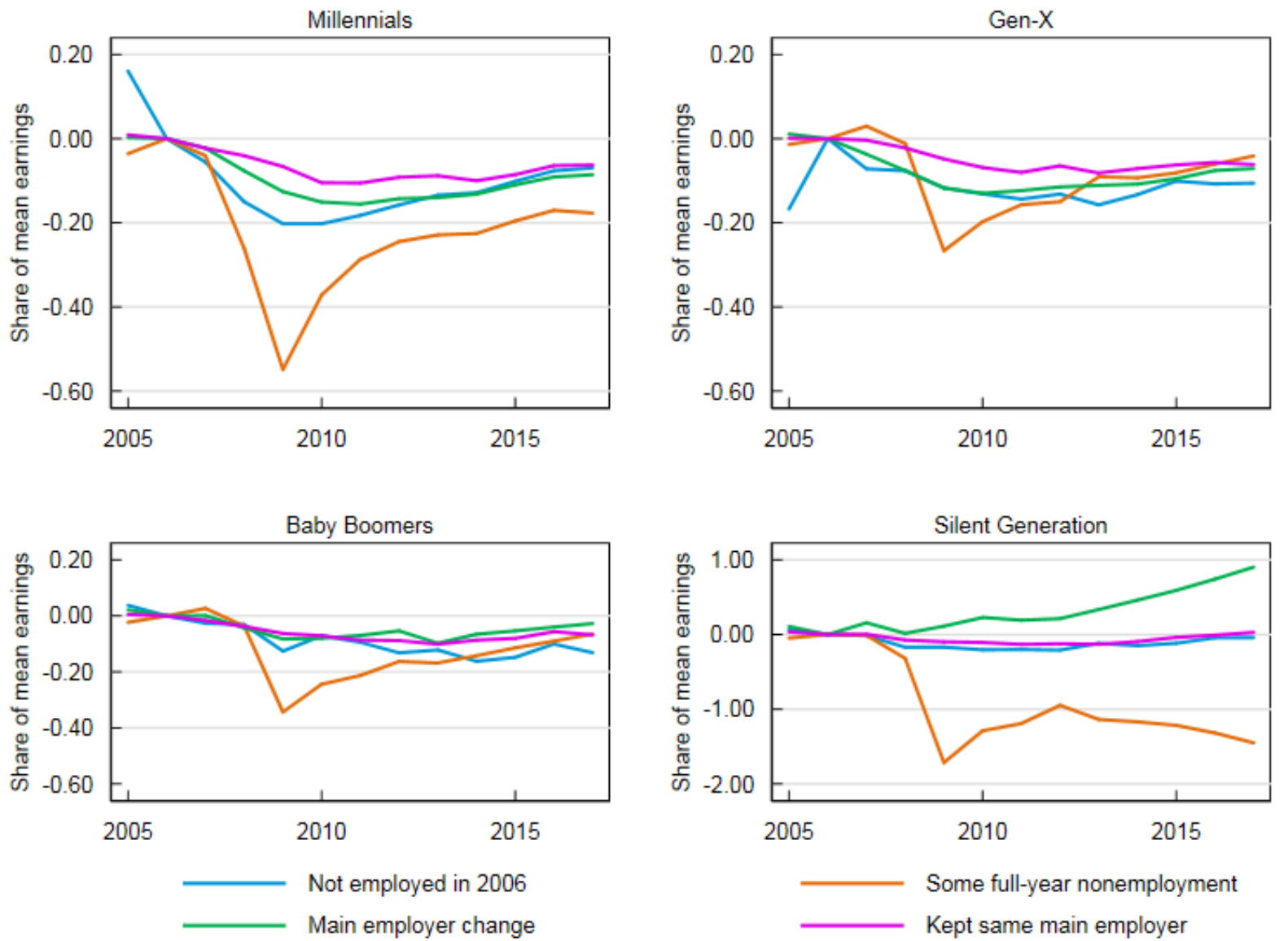

Source: Form 1040, Form 1099, Form W-2, Census Numident, American Community Survey (2001 through 2017), Decennial Census (2000 and 2010), MAF-ARF. Release authorization number CBDRB-FY19-431.

Note: Points plotted are $\beta$ coefficients as estimated in Equation 1, multiplied by the magnitude of the average local unemployment shock and then divided by the mean of the corresponding outcome for the relevant group and year. 


\section{Appendix E Race Estimates by Generation}

Figure E1: Effects of Local Unemployment Shocks on Employment, by Race, Millennials
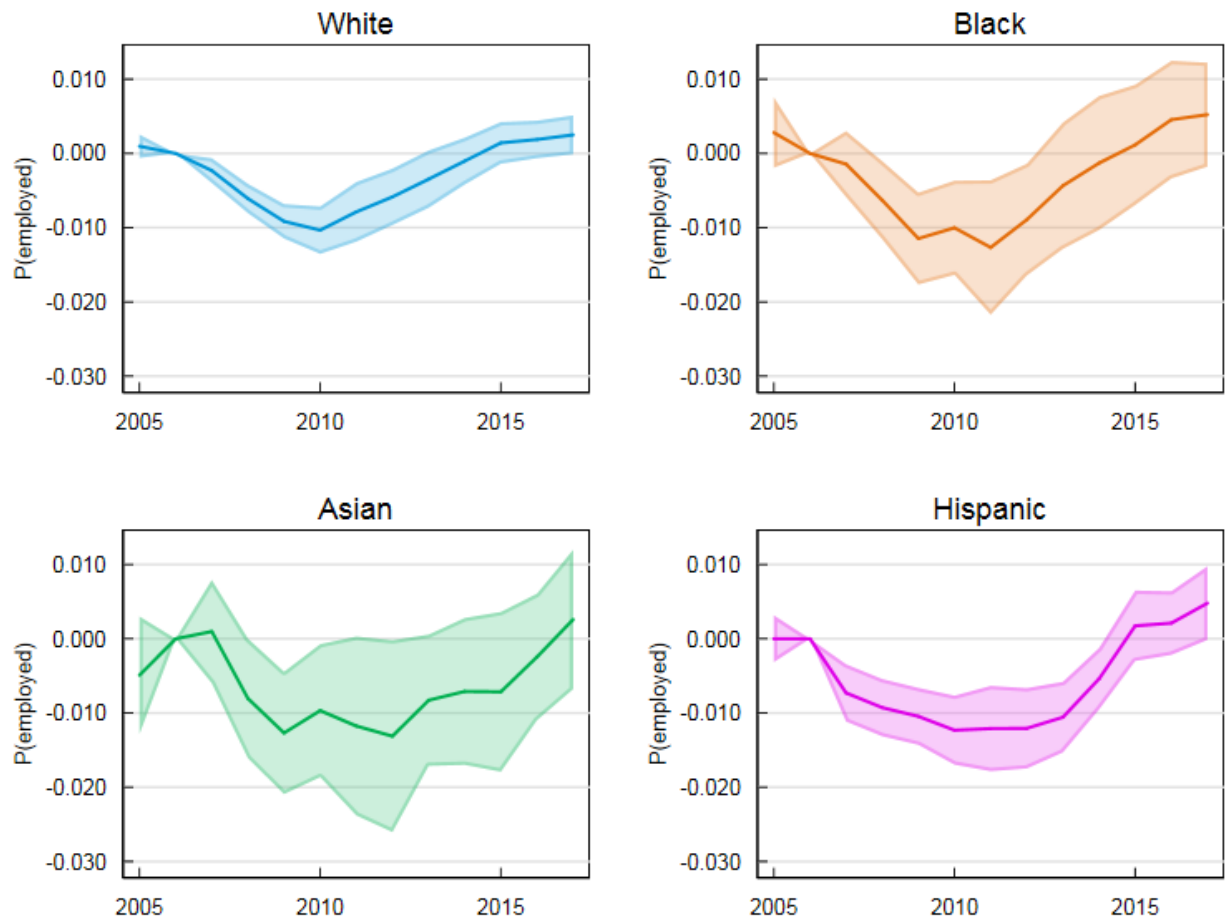

Source: Form 1040, Form 1099, Form W-2, Census Numident, American Community Survey (2001 through 2017), Decennial Census (2000 and 2010), MAF-ARF. Release authorization number CBDRB-FY19-376.

Note: Points plotted are $\beta$ coefficients as estimated in Equation 1. Shaded regions represent 95 percent confidence intervals. 
Figure E2: Effects of Local Unemployment Shocks on Earnings, by Race, Millennials
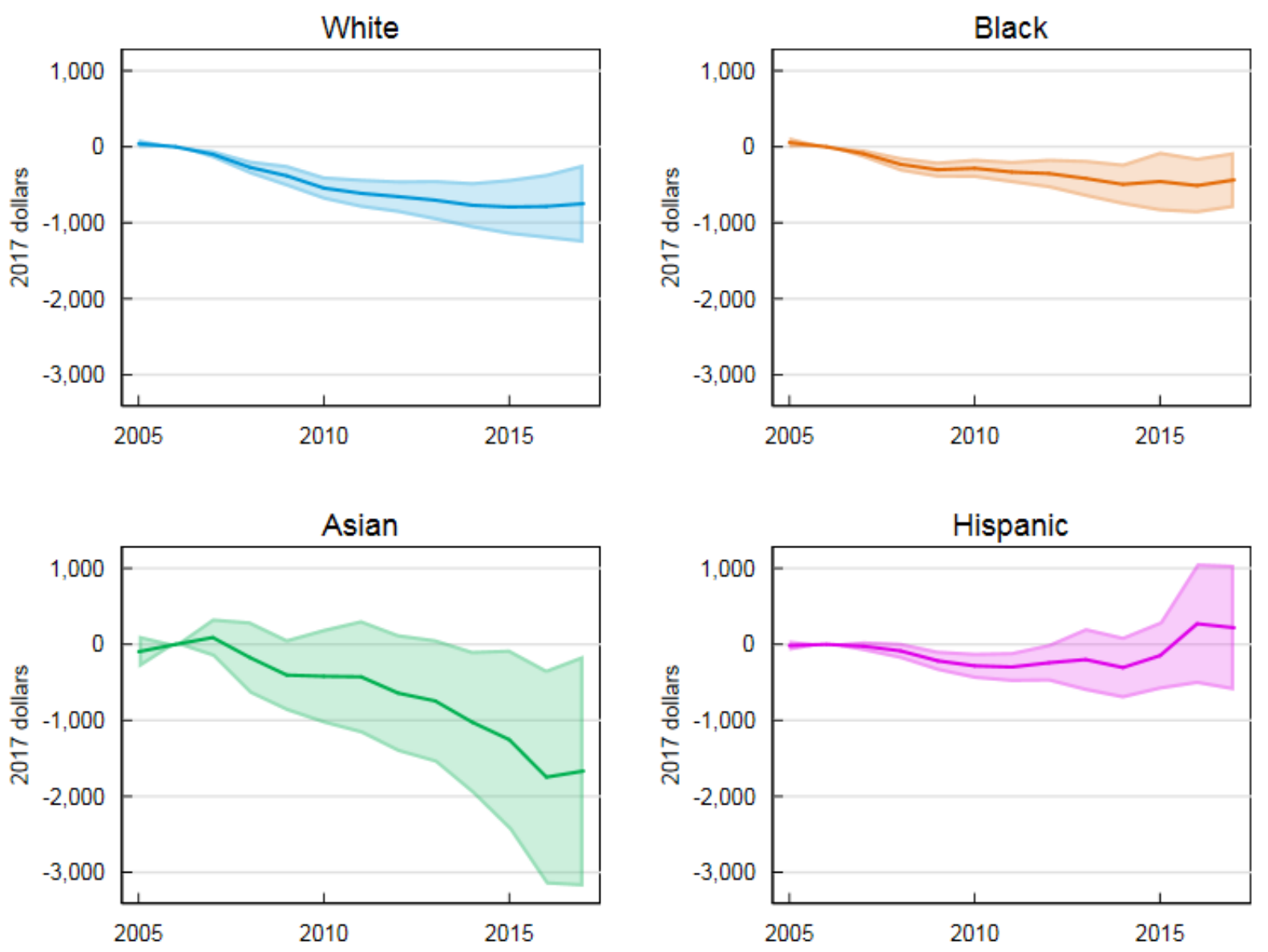

Source: Form 1040, Form 1099, Form W-2, Census Numident, American Community Survey (2001 through 2017), Decennial Census (2000 and 2010), MAF-ARF. Release authorization number CBDRB-FY19-376.

Note: Points plotted are $\beta$ coefficients as estimated in Equation 1. Shaded regions represent 95 percent confidence intervals. 
Figure E3: Effects of Local Unemployment Shocks on Employment and Earnings, Coefficients as Share of Outcome Mean, by Race, Millennials
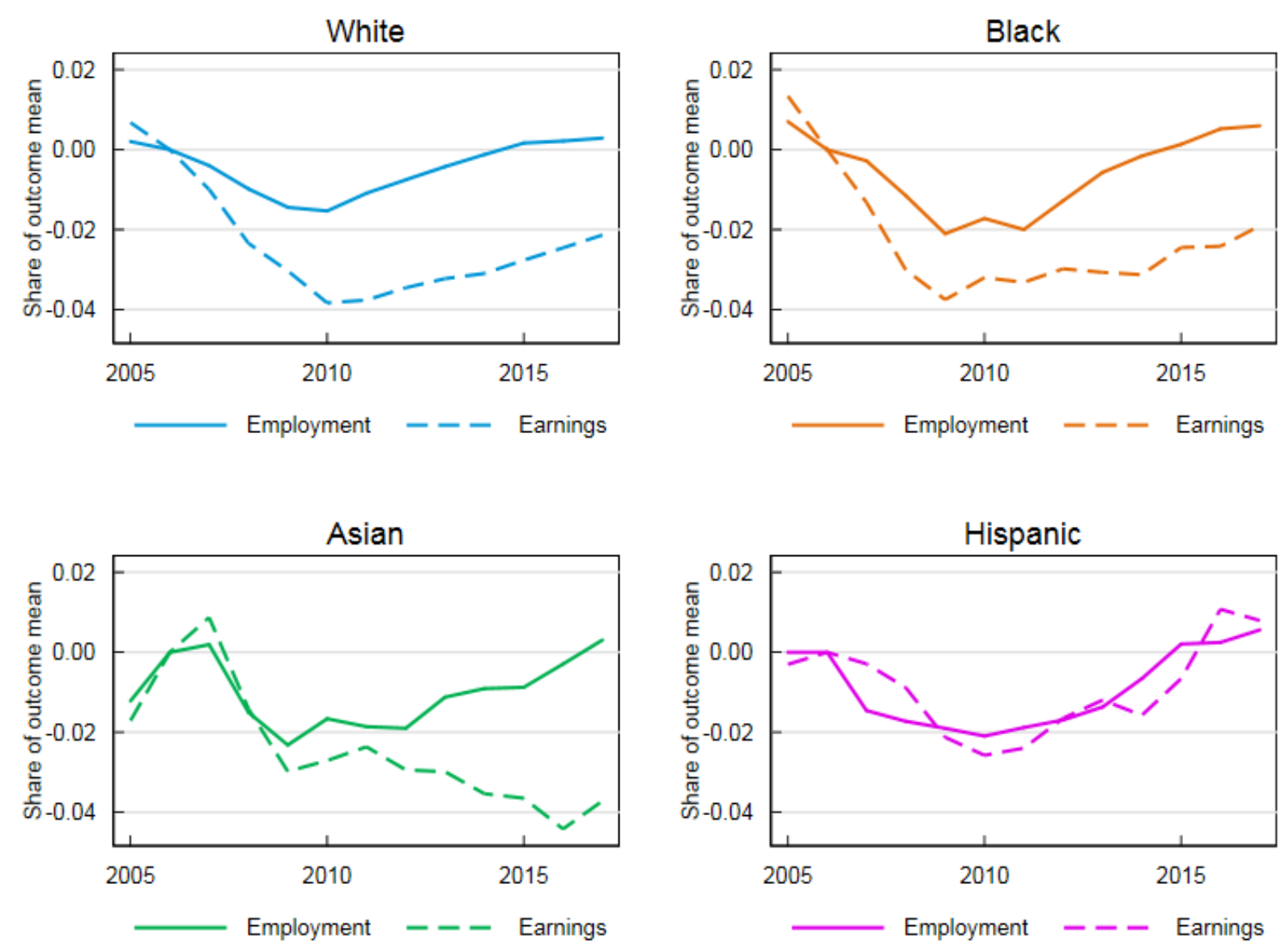

Source: Form 1040, Form 1099, Form W-2, Census Numident, American Community Survey (2001 through 2017), Decennial Census (2000 and 2010$)$, MAF-ARF Release authorization number CBDRB-FY19-376.

Note: Points plotted are $\beta$ coefficients as estimated in Equation 1, divided by the mean of the corresponding outcome for the relevant group and year. 
Figure E4: Effects of Local Unemployment Shocks on Employment and Earnings, Effects of Average Shock as Share of Outcome Mean, by Race, Millennials
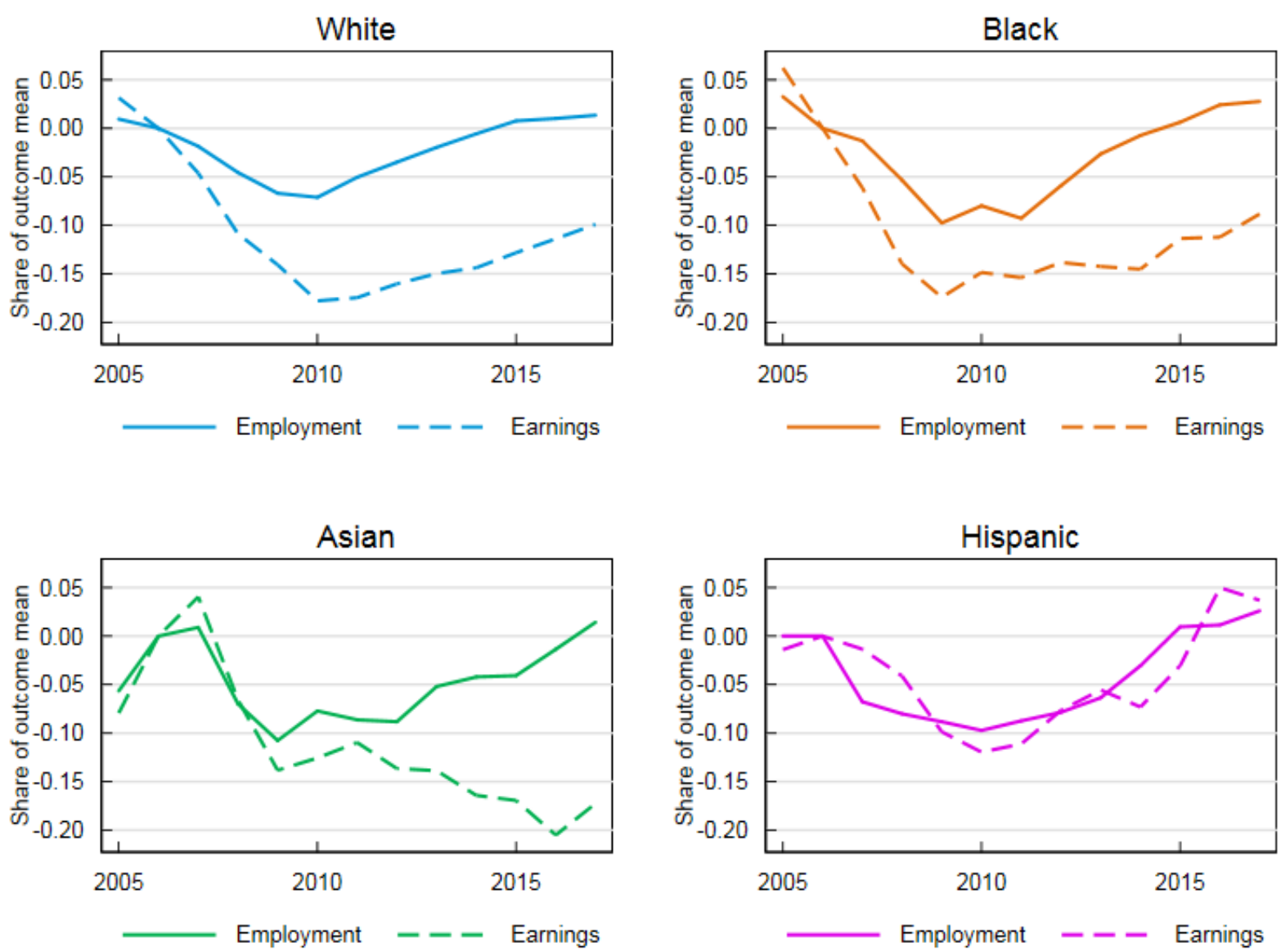

Source: Form 1040, Form 1099, Form W-2, Census Numident, American Community Survey (2001 through 2017), Decennial Census (2000 and 2010), MAF-ARF. Release authorization number CBDRB-FY19-376.

Note: Points plotted are $\beta$ coefficients as estimated in Equation 1 , multiplied by the magnitude of the average local unemployment shock and then divided by the mean of the corresponding outcome for the relevant group and year. 
Figure E5: Effects of Local Unemployment Shocks on Employment, by Race, Generation X
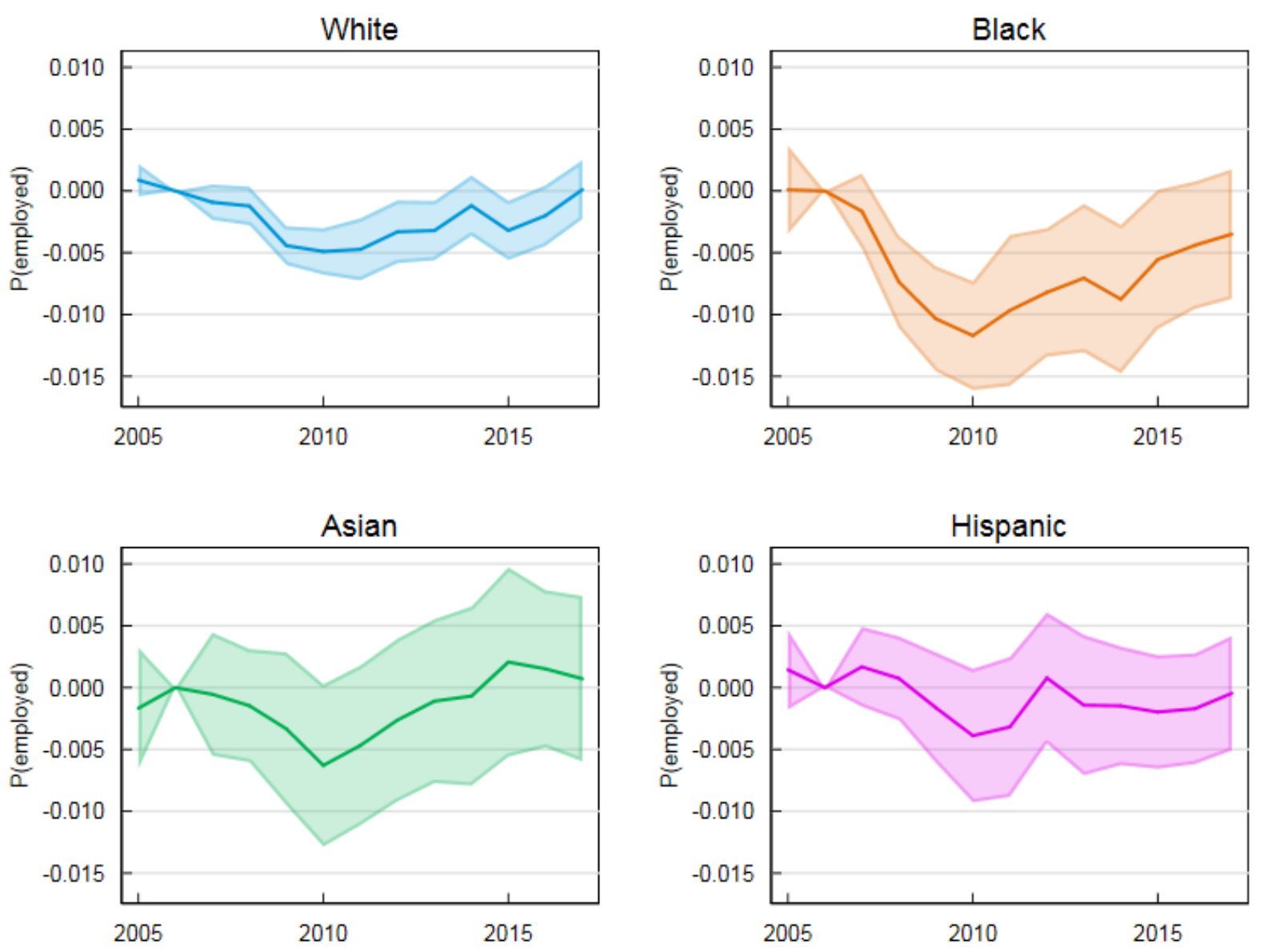

Source: Form 1040, Form 1099, Form W-2, Census Numident, American Community Survey (2001 through 2017), Decennial Census (2000 and 2010), MAF-ARF. Release authorization number CBDRB-FY19-376.

Note: Points plotted are $\beta$ coefficients as estimated in Equation 1. Shaded regions represent 95 percent confidence intervals. 
Figure E6: Effects of Local Unemployment Shocks on Earnings, by Race, Generation X
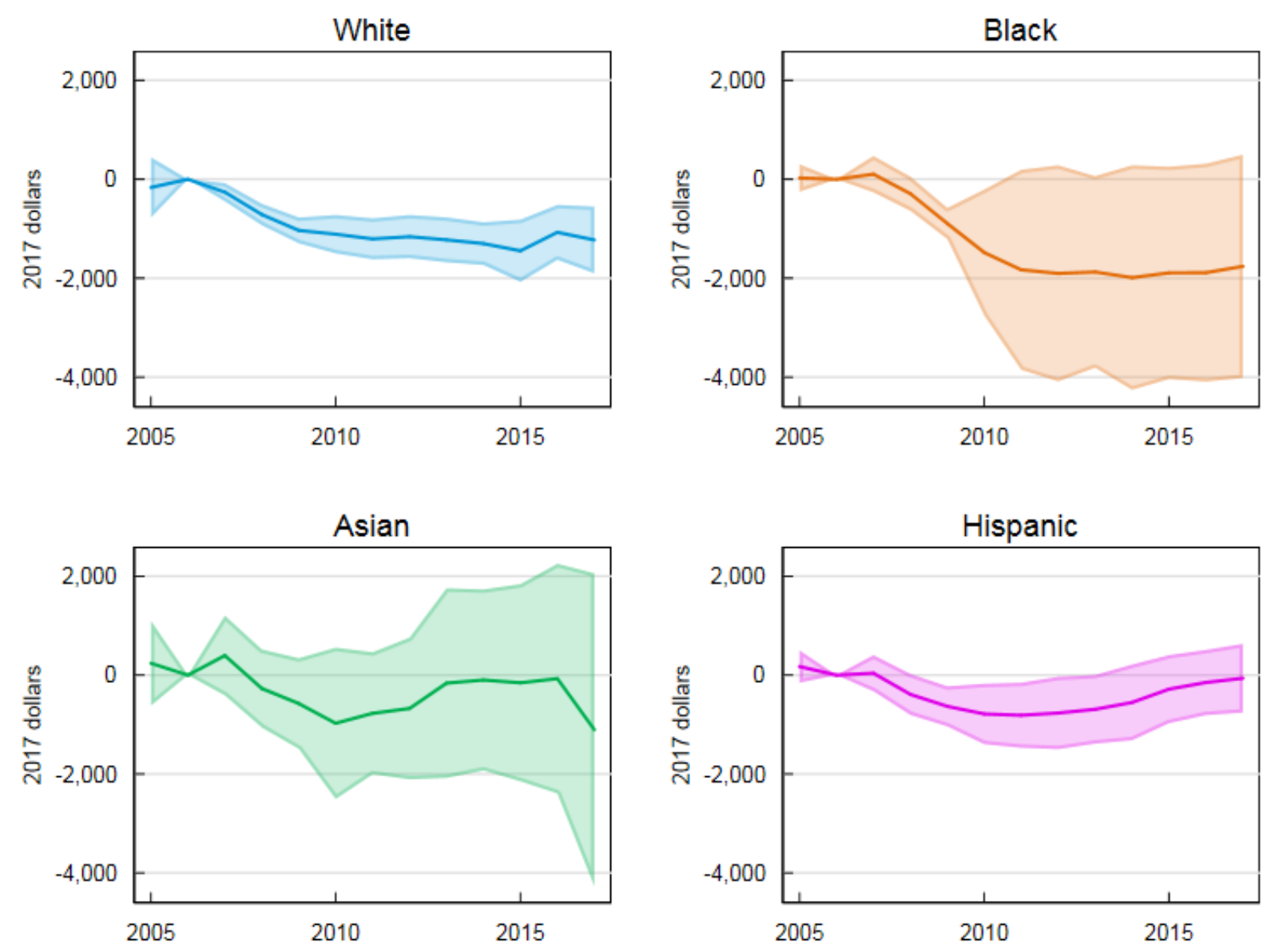

Source: Form 1040, Form 1099, Form W-2, Census Numident, American Community Survey (2001 through 2017), Decennial Census (2000 and 2010), MAF-ARF. Release authorization number CBDRB-FY19-431.

Note: Points plotted are $\beta$ coefficients as estimated in Equation 1. Shaded regions represent 95 percent confidence intervals. 
Figure E7: Effects of Local Unemployment Shocks on Employment and Earnings, Coefficients as Share of Outcome Mean, by Race, Generation X
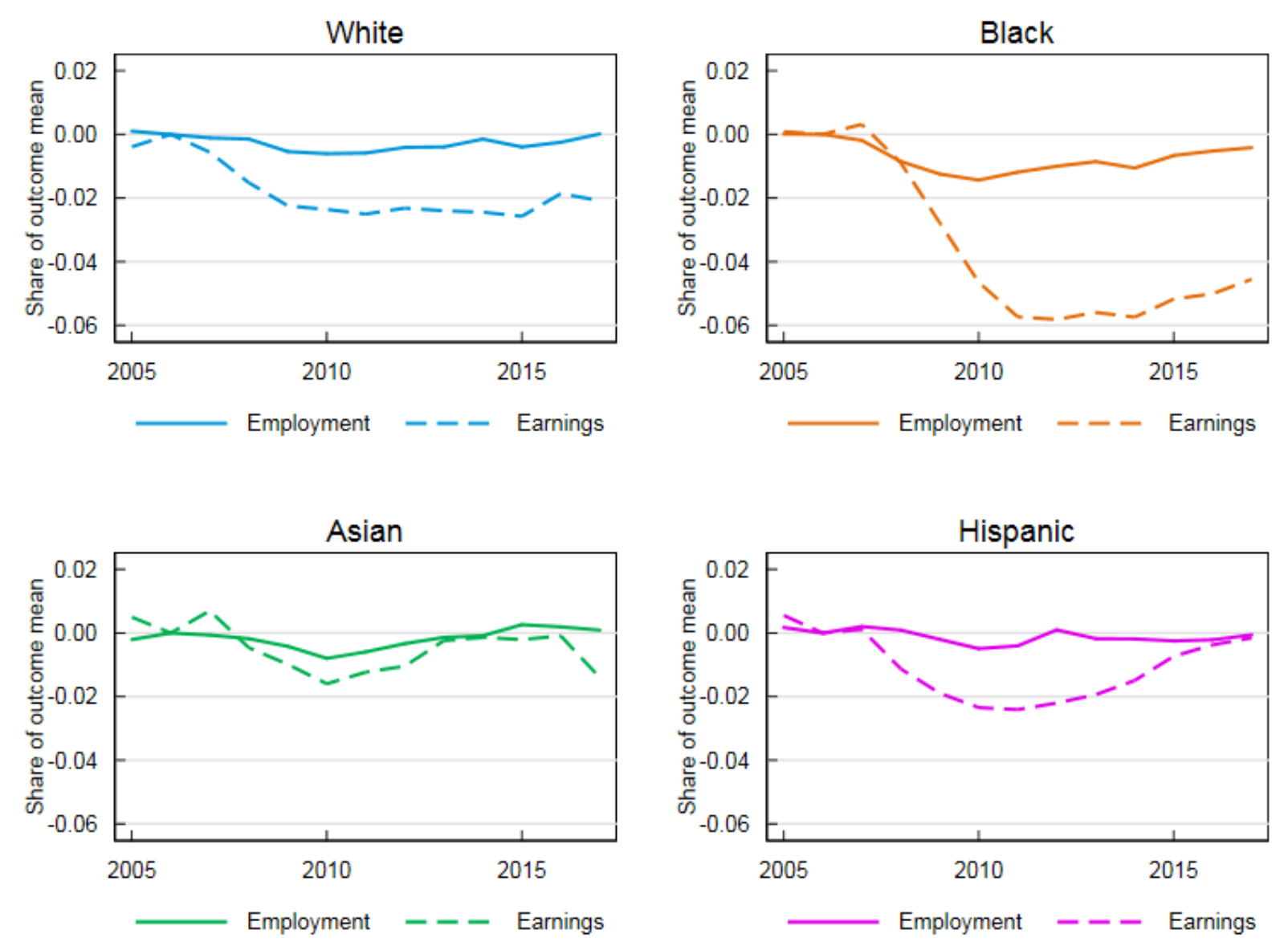

Source: Form 1040, Form 1099, Form W-2, Census Numident, American Community Survey (2001 through 2017), Decennial Census (2000 and 2010$)$, MAF-ARF. Release authorization number CBDRB-FY19-376.

Note: Points plotted are $\beta$ coefficients as estimated in Equation 1, divided by the mean of the corresponding outcome for the relevant group and year. 
Figure E8: Effects of Local Unemployment Shocks on Employment and Earnings, Effects of Average Shock as Share of Outcome Mean, by Race, Generation X
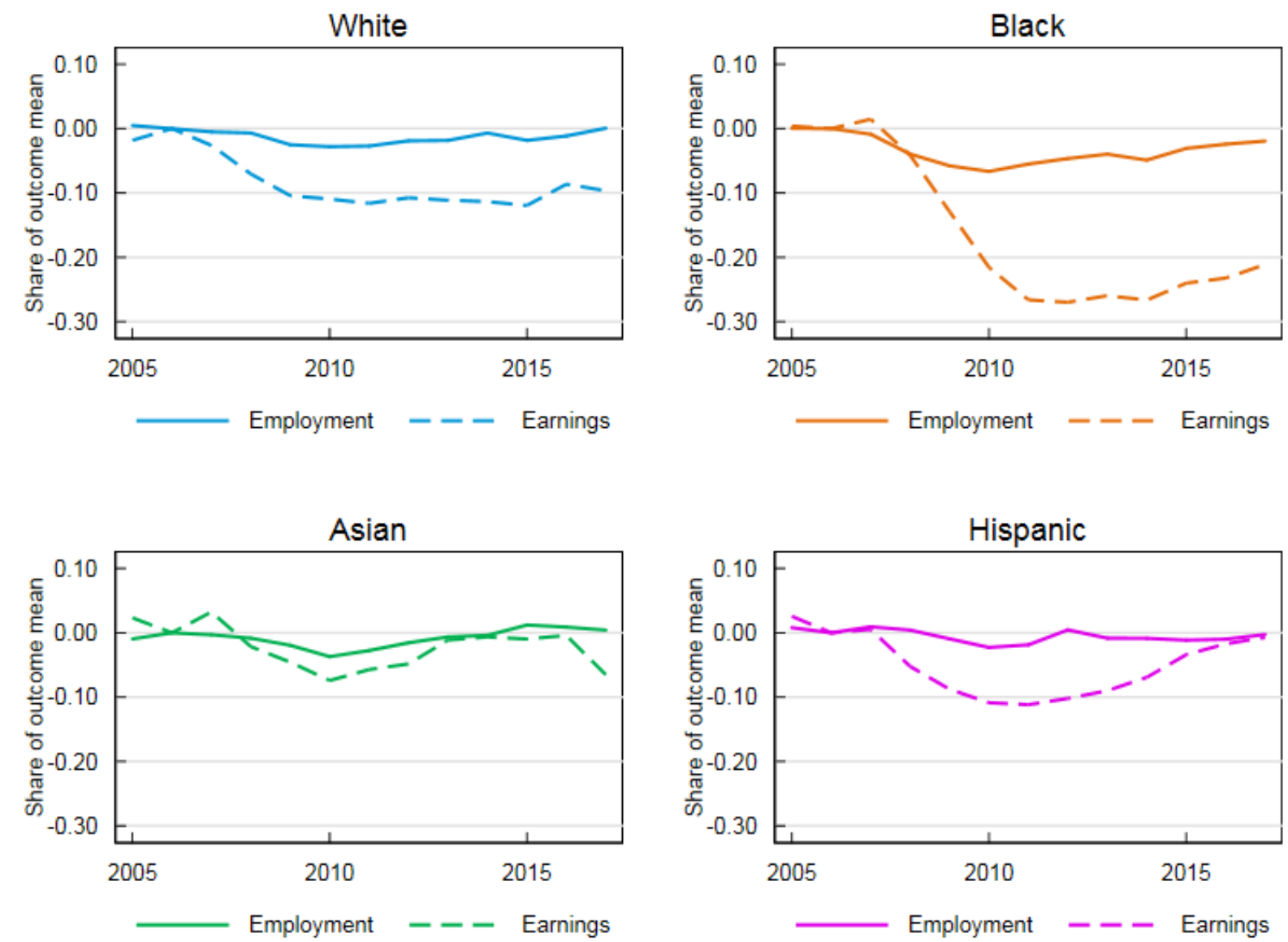

Source: Form 1040, Form 1099, Form W-2, Census Numident, American Community Survey (2001 through 2017), Decennial Census (2000 and 2010 ), MAF-ARF. Release authorization number CBDRB-FY19-376.

Note: Points plotted are $\beta$ coefficients as estimated in Equation 1 , multiplied by the magnitude of the average local unemployment shock and then divided by the mean of the corresponding outcome for the relevant group and year. 
Figure E9: Effects of Local Unemployment Shocks on Employment, by Race, Baby Boomers
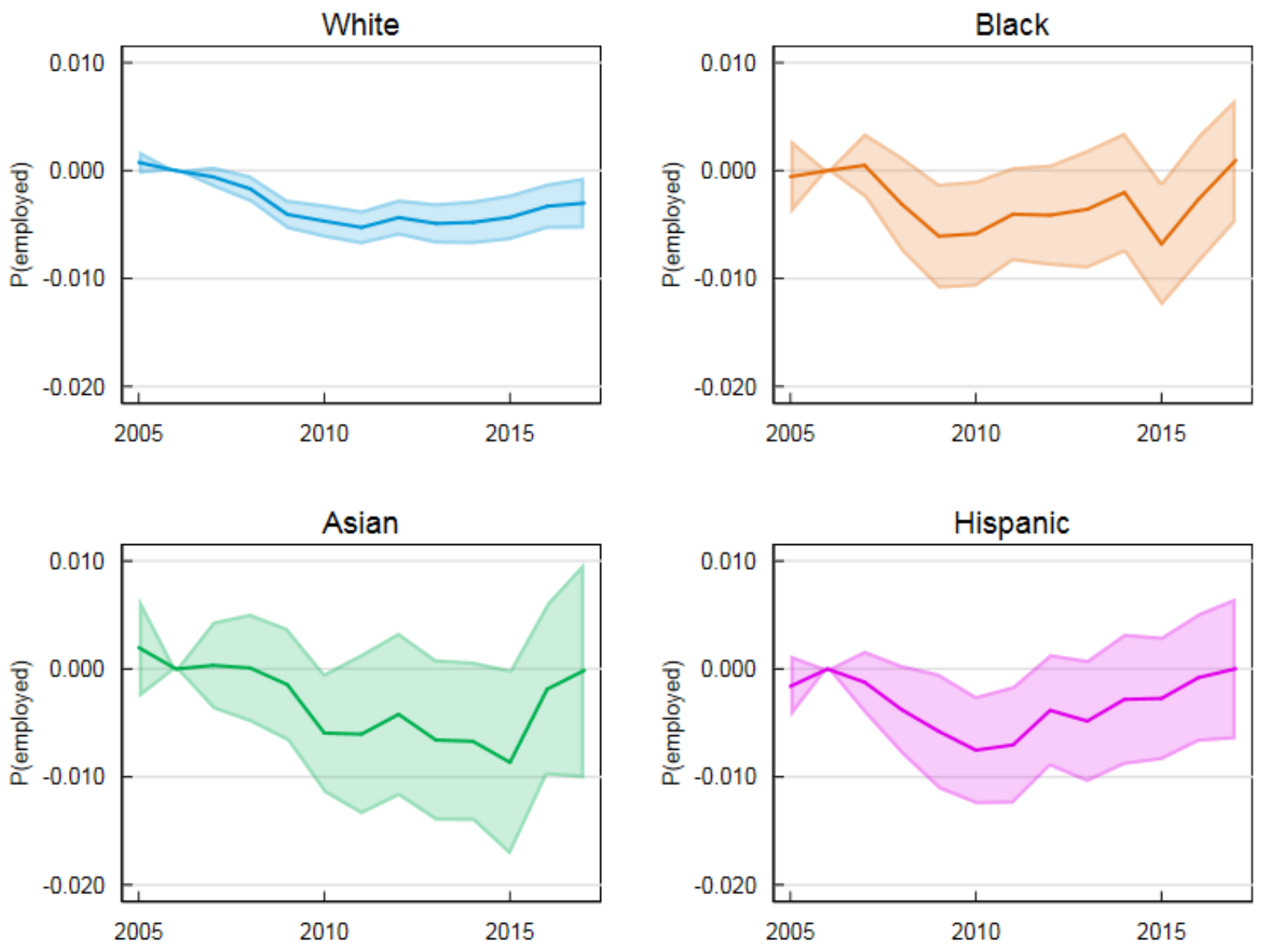

Source: Form 1040, Form 1099, Form W-2, Census Numident, American Community Survey (2001 through 2017), Decennial Census (2000 and 2010), MAF-ARF. Release authorization number CBDRB-FY19-376.

Note: Points plotted are $\beta$ coefficients as estimated in Equation 1. Shaded regions represent 95 percent confidence intervals. 
Figure E10: Effects of Local Unemployment Shocks on Earnings, by Race, Baby Boomers
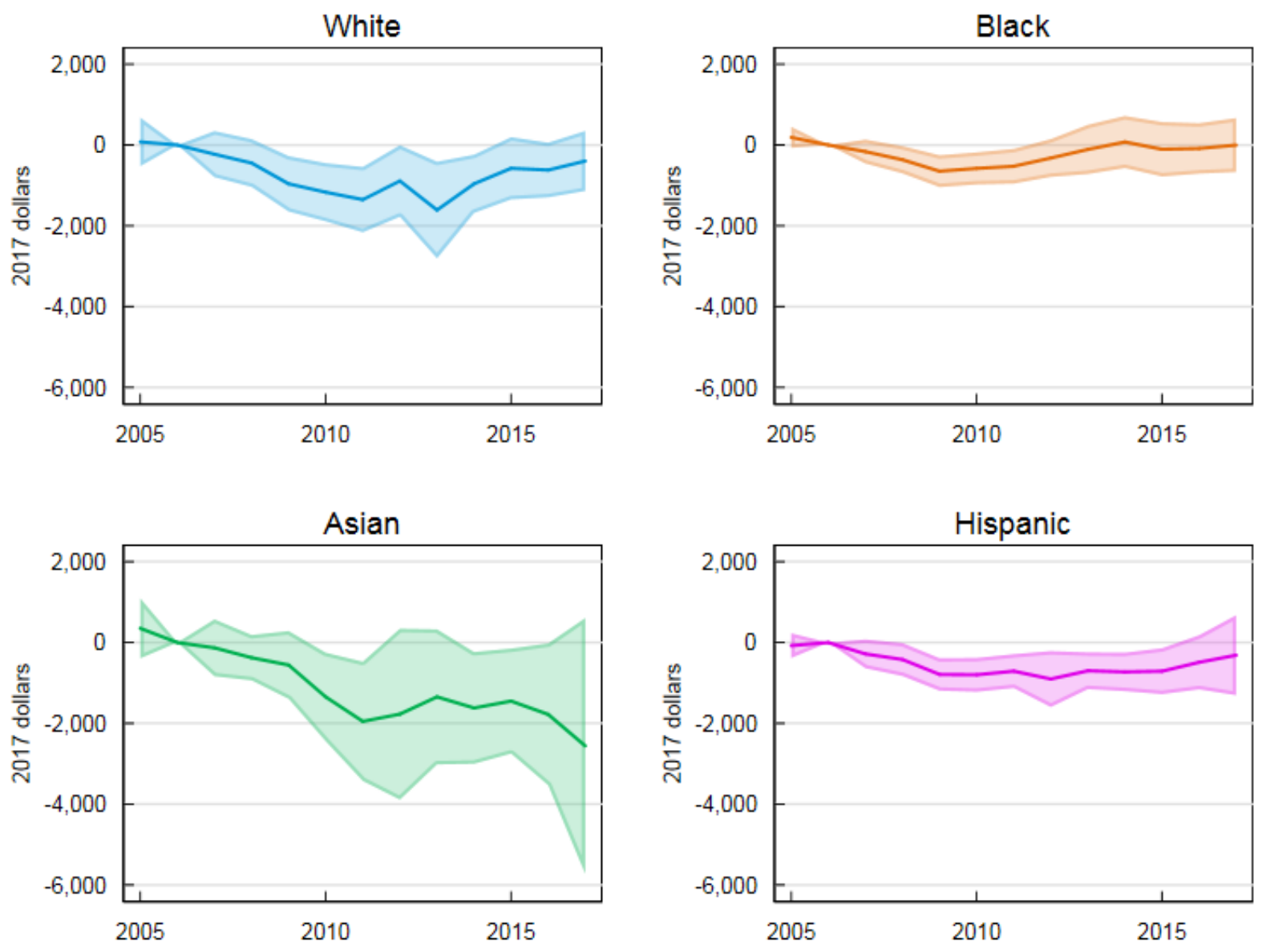

Source: Form 1040, Form 1099, Form W-2, Census Numident, American Community Survey (2001 through 2017), Decennial Census (2000 and 2010), MAF-ARF. Release authorization number CBDRB-FY19-376.

Note: Points plotted are $\beta$ coefficients as estimated in Equation 1. Shaded regions represent 95 percent confidence intervals. 
Figure E11: Effects of Local Unemployment Shocks on Employment and Earnings, Coefficients as Share of Outcome Mean, by Race, Baby Boomers
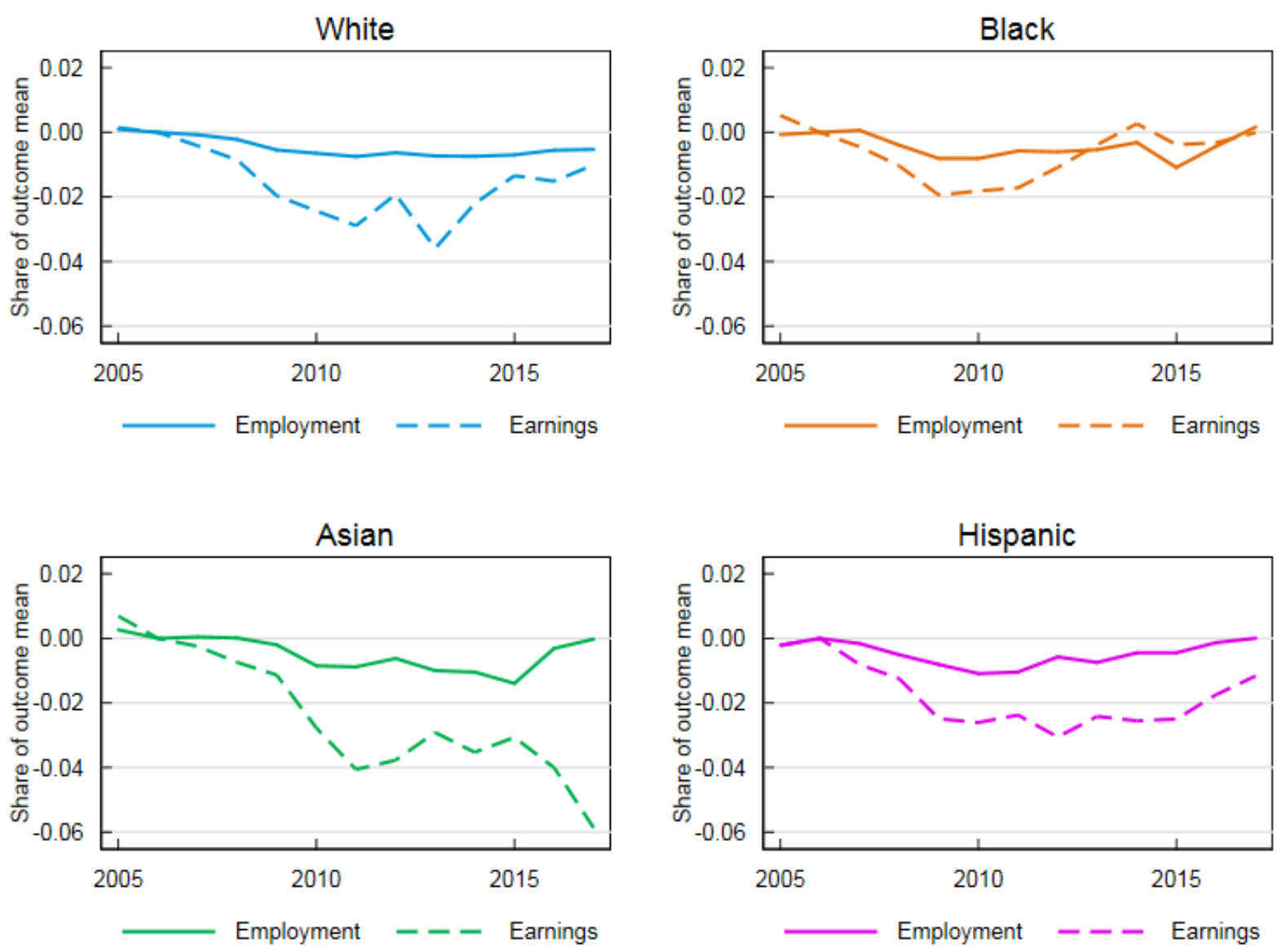

Source: Form 1040, Form 1099, Form W-2, Census Numident, American Community Survey (2001 through 2017), Decennial Census (2000 and 2010 ), MAF-ARF. Release authorization number CBDRB-FY19-376.

Note: Points plotted are $\beta$ coefficients as estimated in Equation 1. divided by the mean of the corresponding outcome for the relevant group and year. 
Figure E12: Effects of Local Unemployment Shocks on Employment and Earnings, Effects of Average Shock as Share of Outcome Mean, by Race, Baby Boomers
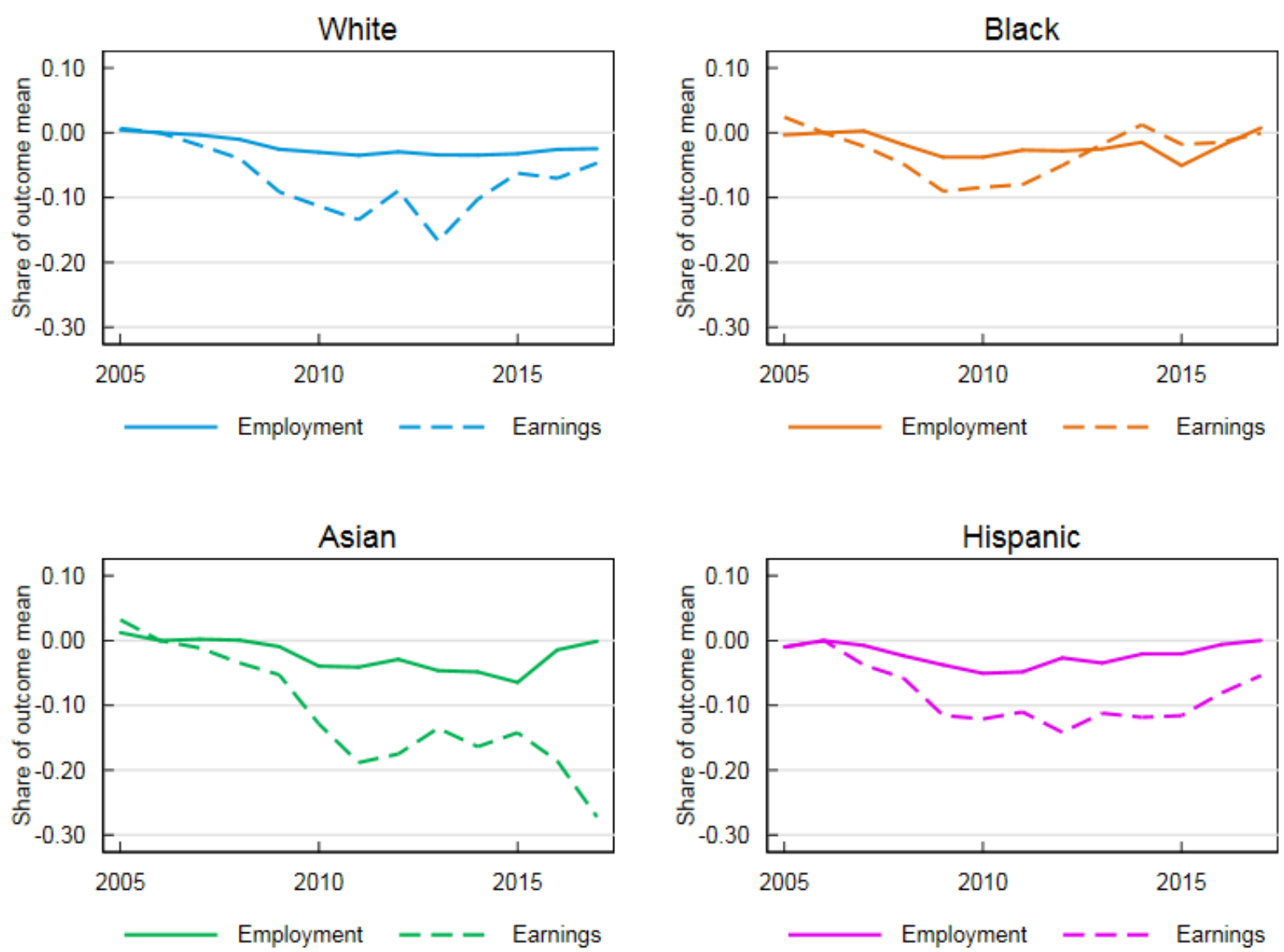

Source: Form 1040, Form 1099, Form W-2, Census Numident, American Community Survey (2001 through 2017), Decennial Census (2000 and 2010 ), MAF-ARF. Release authorization number CBDRB-FY19-376.

Note: Points plotted are $\beta$ coefficients as estimated in Equation 1, multiplied by the magnitude of the average local unemployment shock and then divided by the mean of the corresponding outcome for the relevant group and year. 
Figure E13: Effects of Local Unemployment Shocks on Employment, by Race, Silent Generation
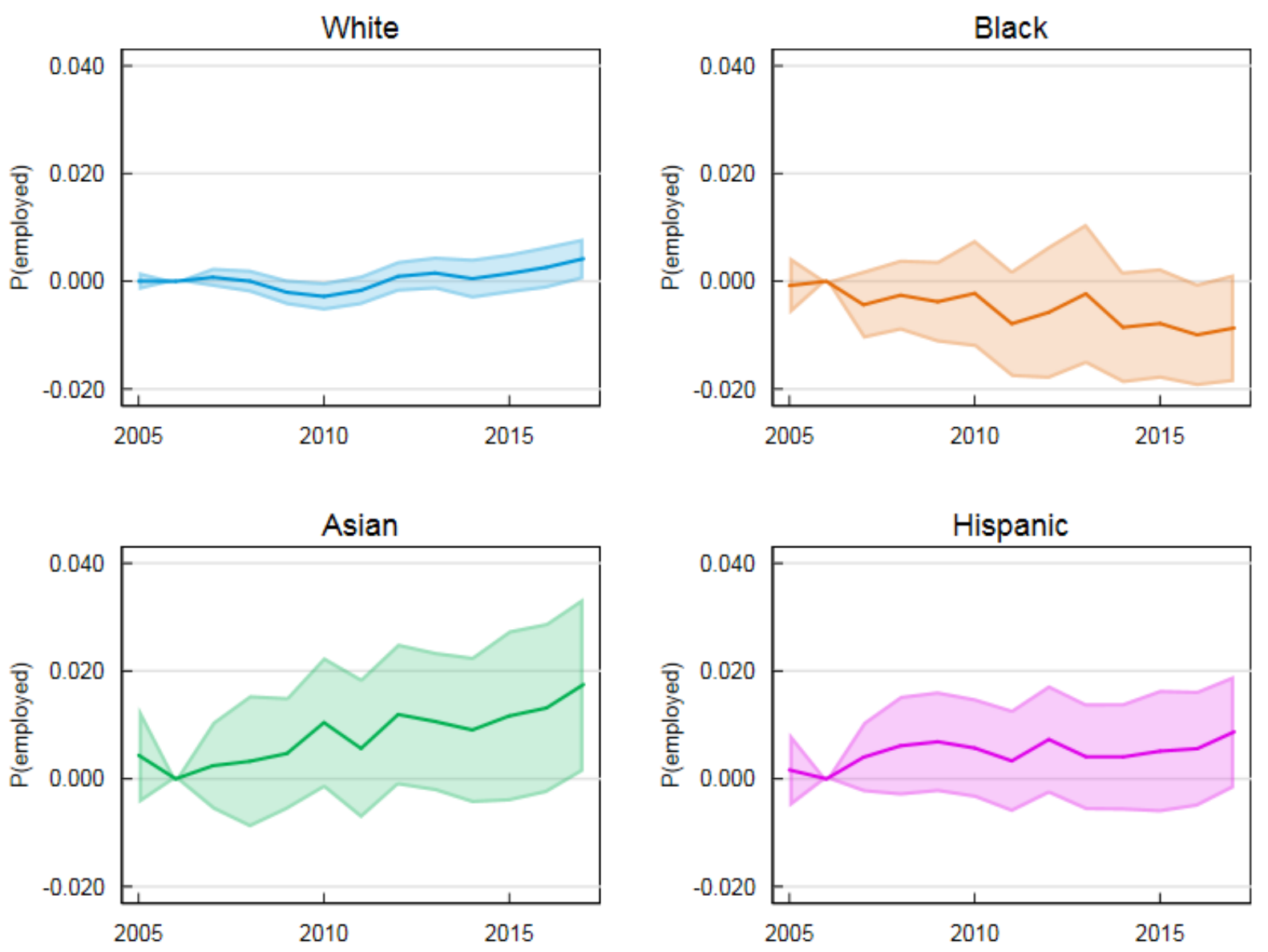

Source: Form 1040, Form 1099, Form W-2, Census Numident, American Community Survey (2001 through 2017), Decennial Census (2000 and 2010), MAF-ARF. Release authorization number CBDRB-FY19-376.

Note: Points plotted are $\beta$ coefficients as estimated in Equation 1. Shaded regions represent 95 percent confidence intervals. 
Figure E14: Effects of Local Unemployment Shocks on Earnings, by Race, Silent Generation
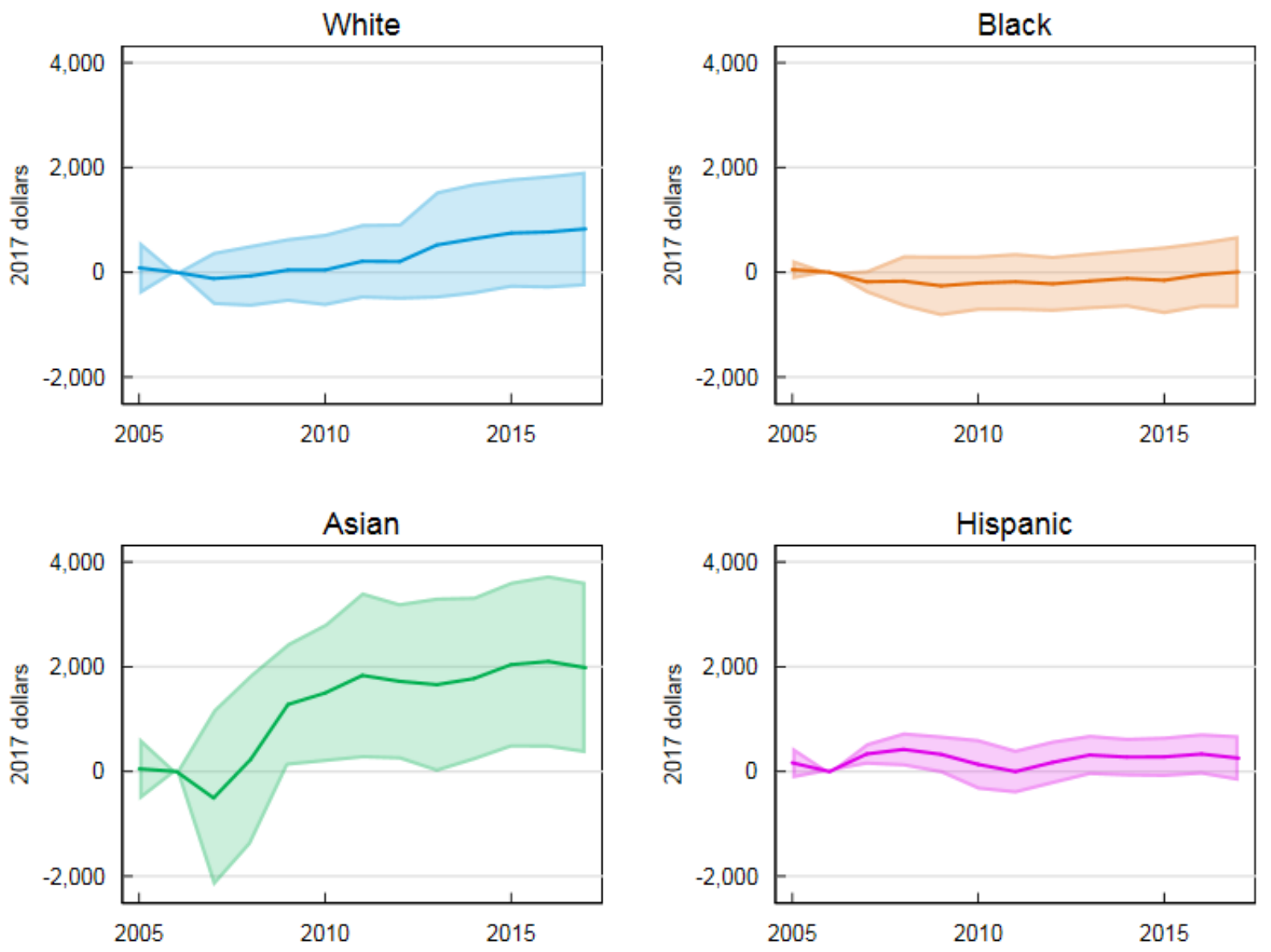

Source: Form 1040, Form 1099, Form W-2, Census Numident, American Community Survey (2001 through 2017), Decennial Census (2000 and 2010), MAF-ARF. Release authorization number CBDRB-FY19-376.

Note: Points plotted are $\beta$ coefficients as estimated in Equation 1. Shaded regions represent 95 percent confidence intervals. 
Figure E15: Effects of Local Unemployment Shocks on Employment and Earnings, Coefficients as Share of Outcome Mean, by Race, Silent Generation
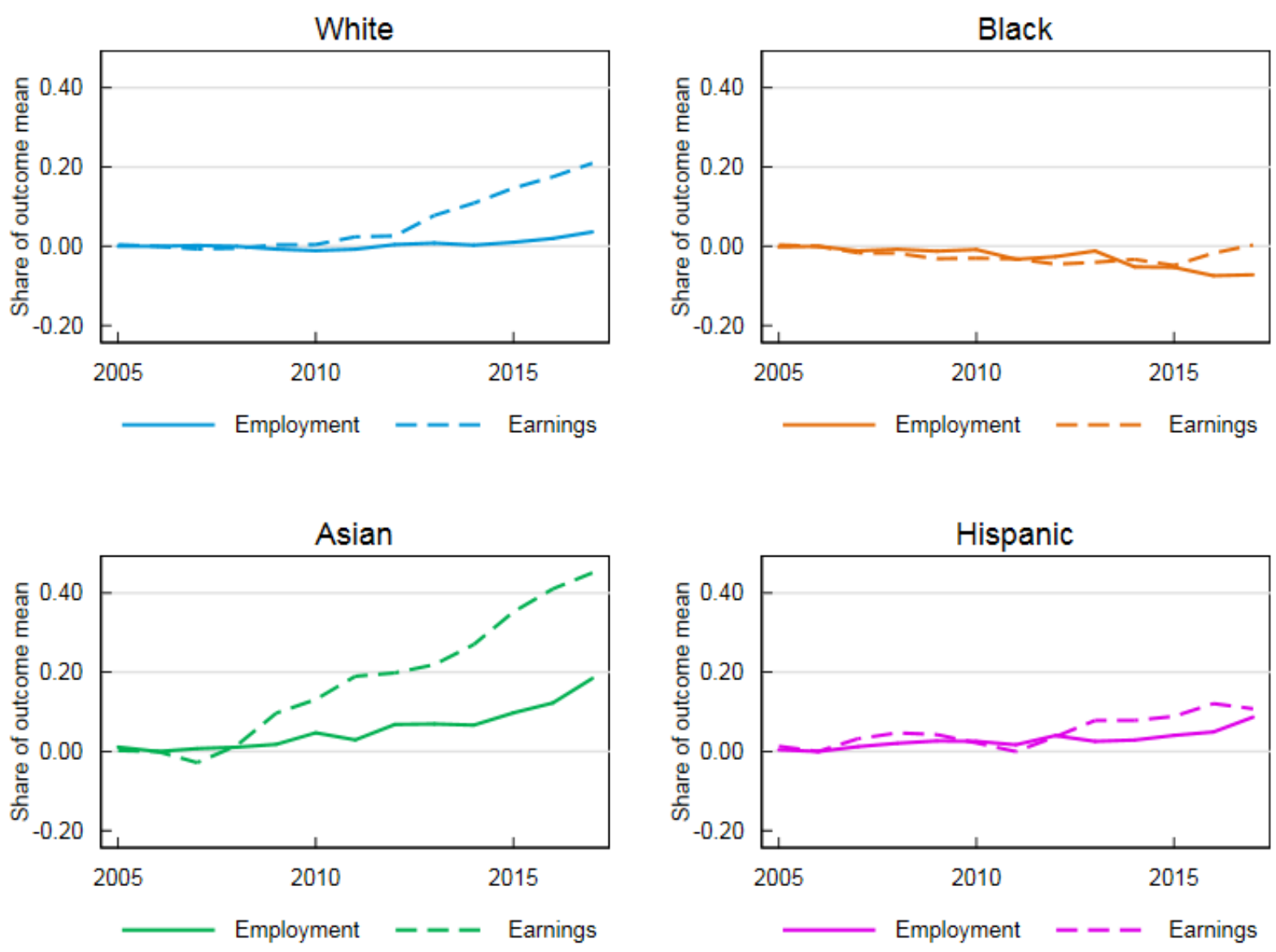

Source: Form 1040, Form 1099, Form W-2, Census Numident, American Community Survey (2001 through 2017), Decennial Census (2000 and 2010 ), MAF-ARF. Release authorization number CBDRB-FY19-376.

Note: Points plotted are $\beta$ coefficients as estimated in Equation 1. divided by the mean of the corresponding outcome for the relevant group and year. 
Figure E16: Effects of Local Unemployment Shocks on Employment and Earnings, Effects of Average Shock as Share of Outcome Mean, by Race, Silent Generation
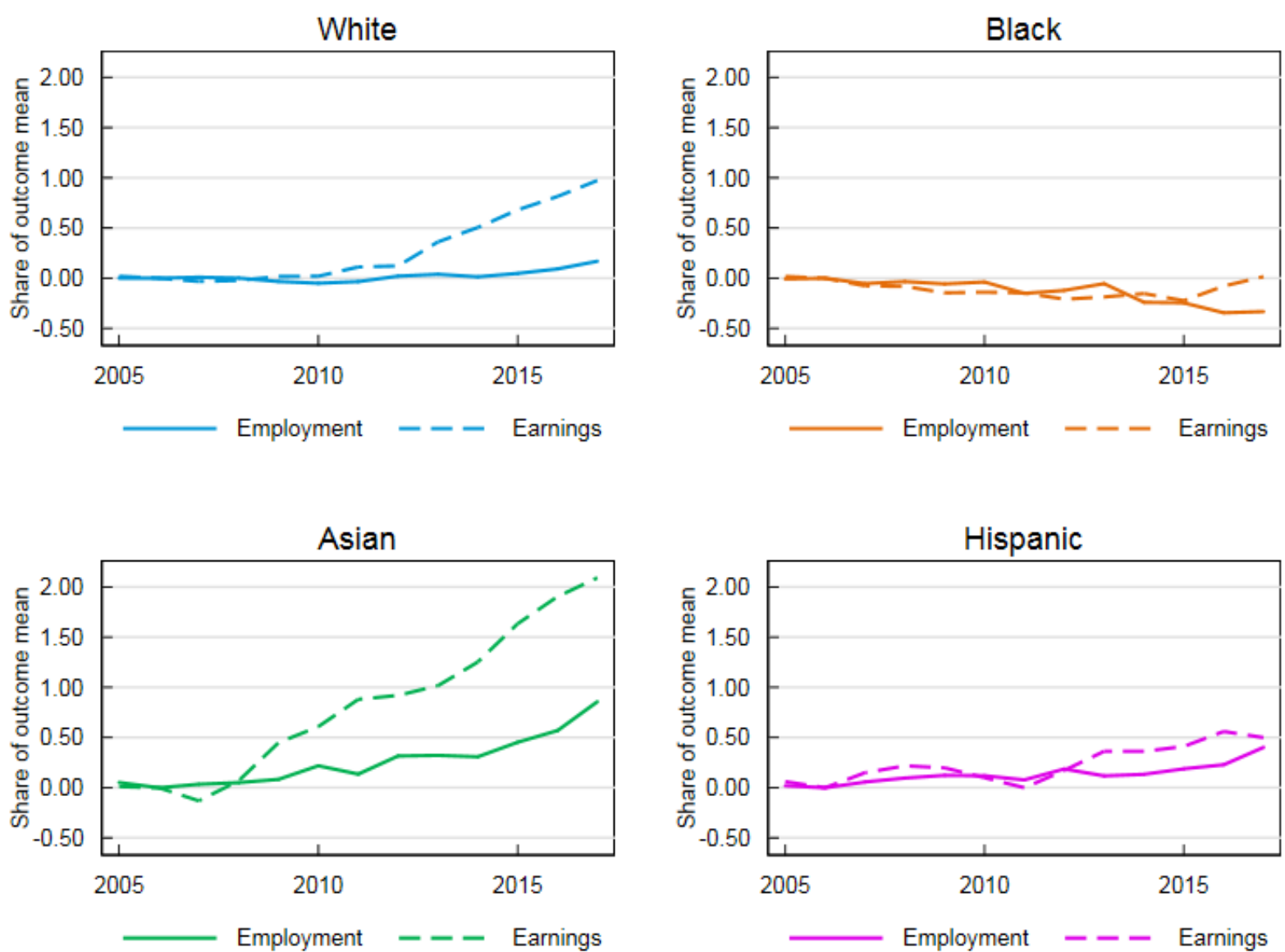

Source: Form 1040, Form 1099, Form W-2, Census Numident, American Community Survey (2001 through 2017), Decennial Census (2000 and 2010 ), MAF-ARF. Release authorization number CBDRB-FY19-376.

Note: Points plotted are $\beta$ coefficients as estimated in Equation 1 , multiplied by the magnitude of the average local unemployment shock and then divided by the mean of the corresponding outcome for the relevant group and year. 


\section{Appendix F Additional Place and Migration Estimates}

Figure F1: Person vs. Place Employment Estimates, by Generation
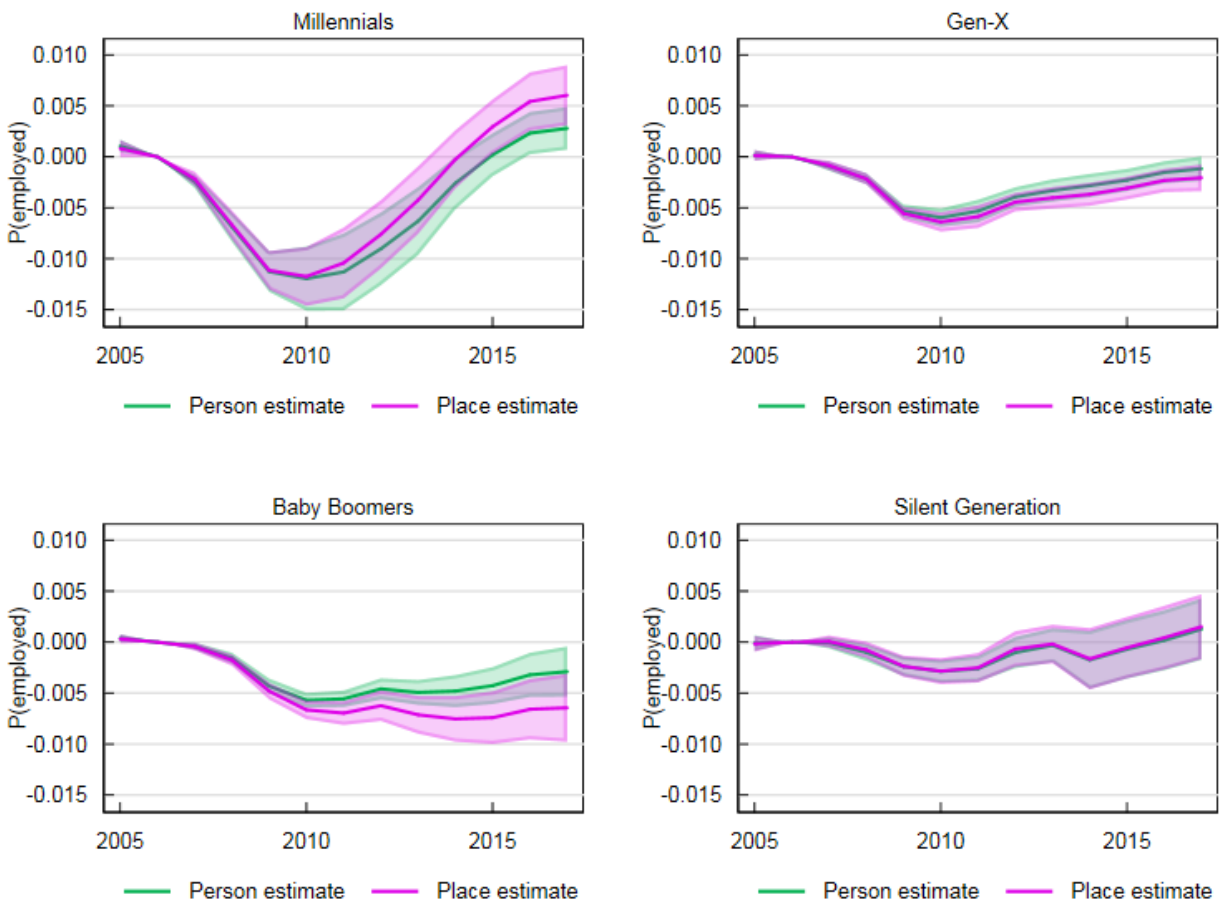

Source: Form 1040, Form 1099, Form W-2, Census Numident, American Community Survey (2001 through 2017), Decennial Census (2000 and 2010), MAF-ARF. Release authorization number CBDRB-FY19-376.

Note: Points plotted are $\beta$ coefficients as estimated in Equation 1. Shaded regions represent 95 percent confidence intervals. 
Figure F2: Person vs. Place Earnings Estimates, by Generation
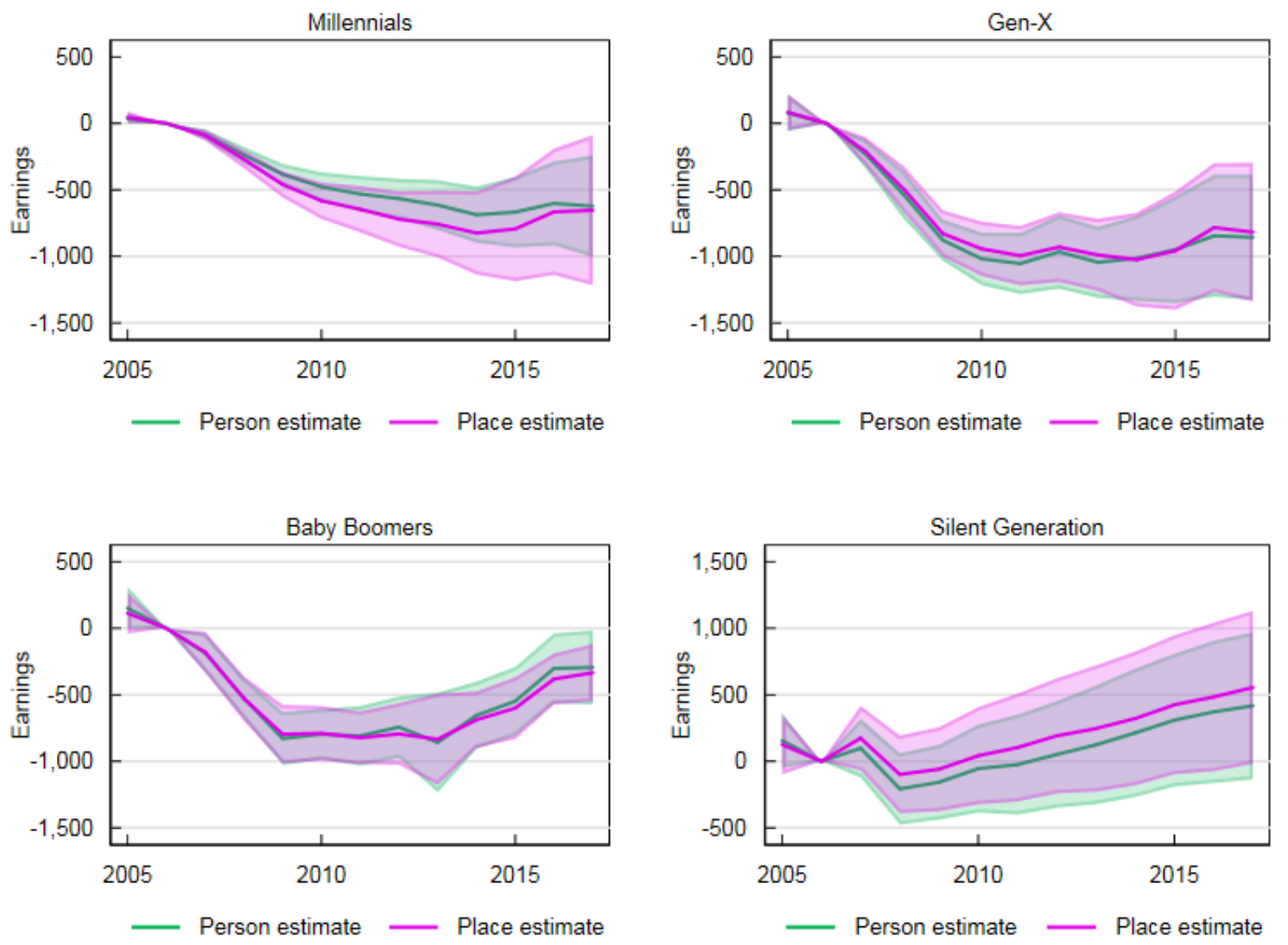

Source: Form 1040, Form 1099, Form W-2, Census Numident, American Community Survey (2001 through 2017), Decennial Census (2000 and 2010 ), MAF-ARF. Release authorization number CBDRB-FY19-376.

Note: Points plotted are $\beta$ coefficients as estimated in Equation 1. Shaded regions represent 95 percent confidence intervals. 
Figure F3: Effects of Local Unemployment Shocks on Migration, 1928-1996 Birth Cohorts

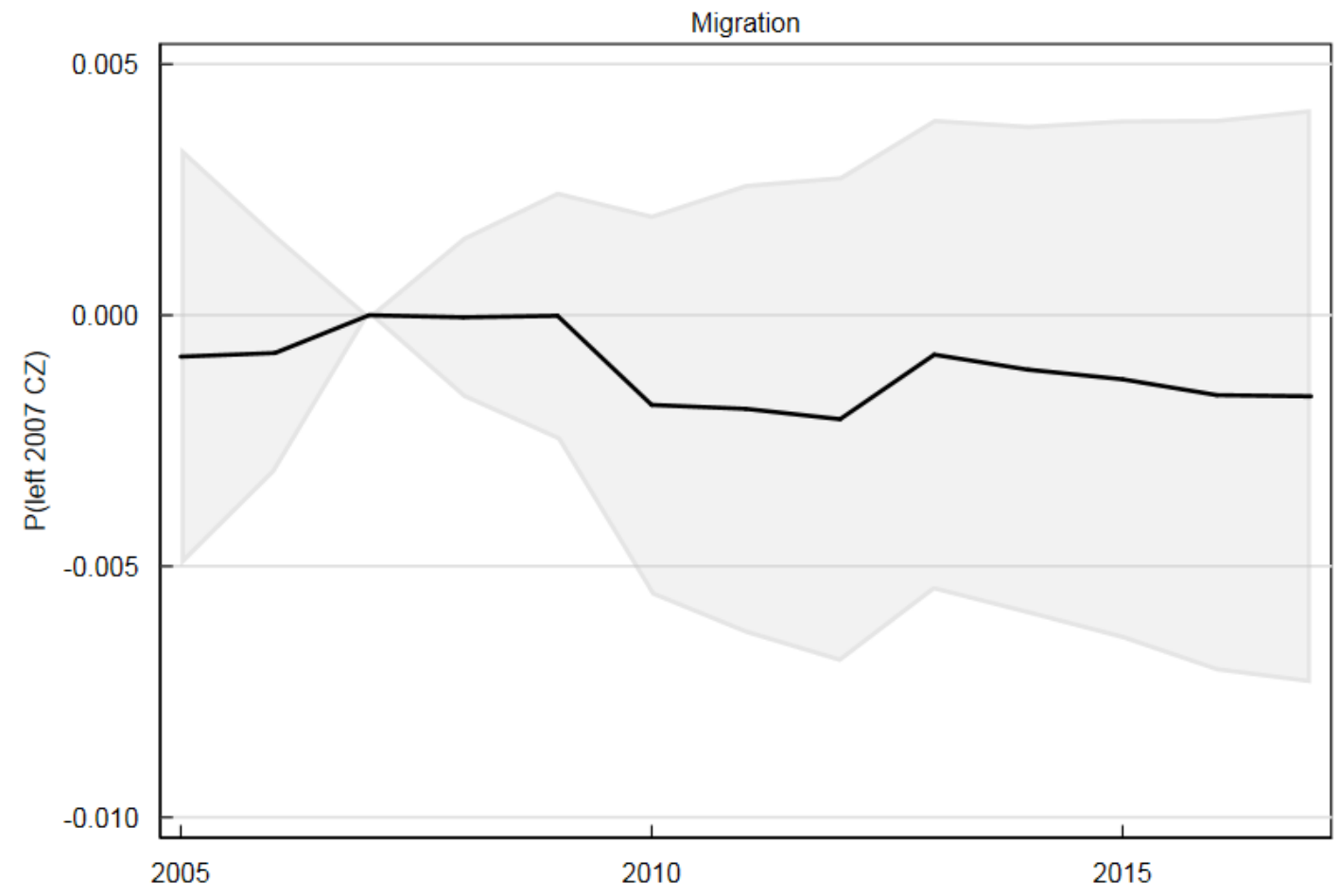

Source: Form 1040, Form 1099, Form W-2, Census Numident, American Community Survey (2001 through 2017), Decennial Census (2000 and 2010), MAF-ARF. Release authorization number CBDRB-FY2019-CES005-013.

Note: Because the measure of migration considered here is the probability of having moved away from one's 2007 commuting zone, this regression uses 2007 as the reference year rather than 2006 . Points plotted are $\beta$ coefficients as estimated in Equation 1 . Shaded regions represent 95 percent confidence intervals. 
Figure F4: Effects of Local Unemployment Shocks on Migration, by Generation
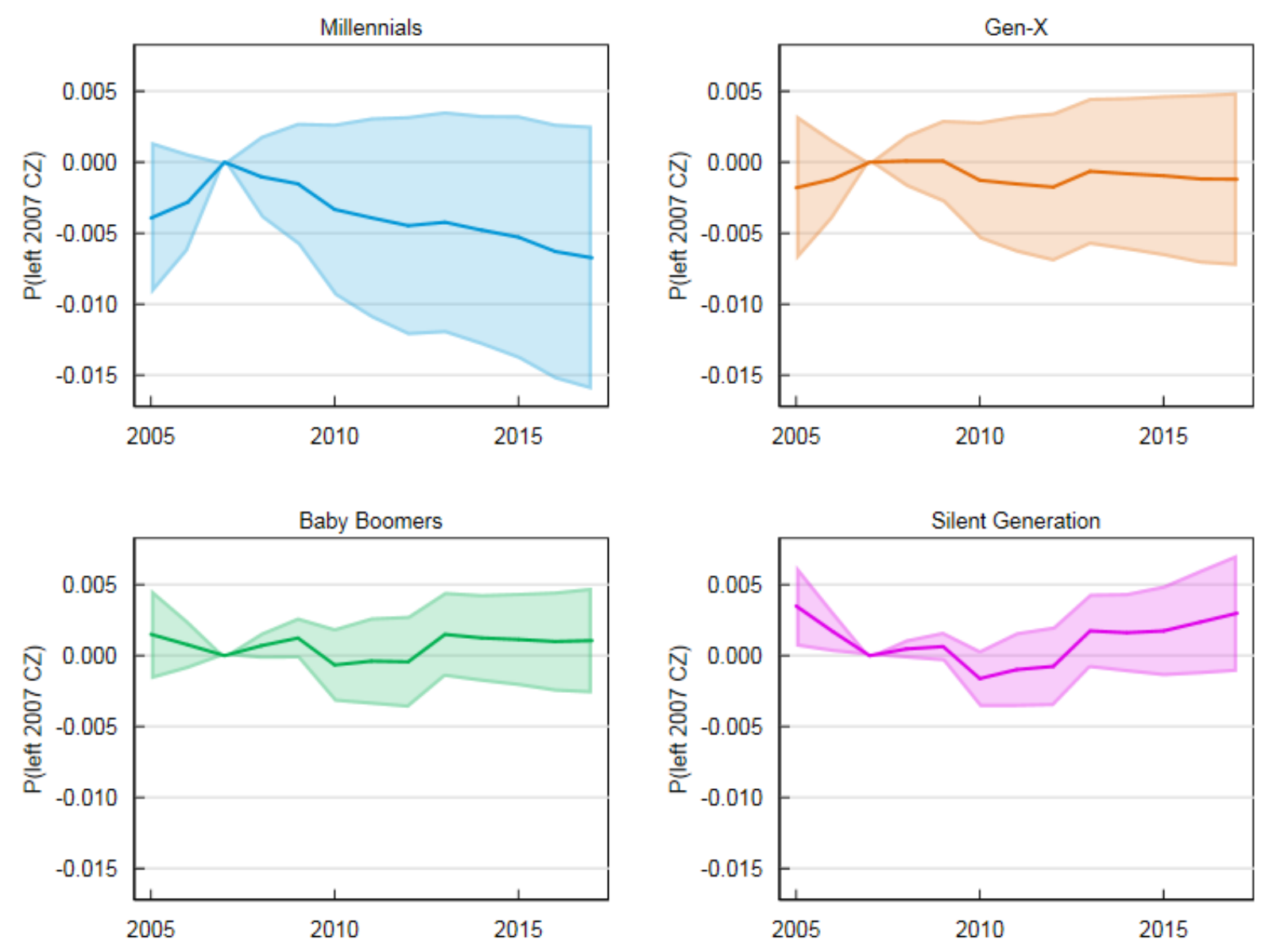

Source: Form 1040, Form 1099, Form W-2, Census Numident, American Community Survey (2001 through 2017), Decennial Census (2000 and 2010), MAF-ARF. Release authorization number CBDRB-FY2019-CES005-013.

Note: Because the measure of migration considered here is the probability of having moved away from one's 2007 commuting zone, this regression uses 2007 as the reference year rather than 2006. Points plotted are $\beta$ coefficients as estimated in Equation 1. Shaded regions represent 95 percent confidence intervals. 